Supporting Information

\title{
Hydroarylation of Arenes via Reductive Radical-Polar Crossover
}

Autumn R. Flynn, ${ }^{\dagger}$ Kelly A. McDaniel, ${ }^{\dagger}$ Meredith E. Hughes, David B. Vogt, Nathan T. Jui ${ }^{*}$ njui@emory.edu

Department of Chemistry and Winship Cancer Institute, Emory University, Atlanta, GA 30322

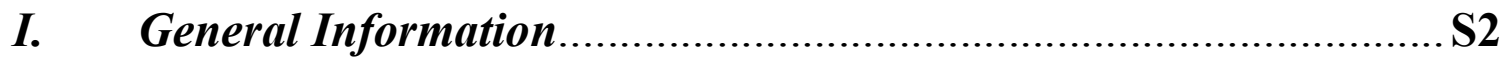

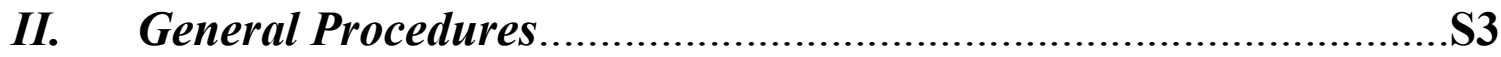

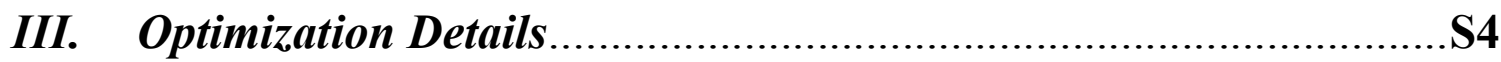

IV. Example of Selectivity: Crude NMR to give Product 5................. S6

V. Fluorescence Quenching and Stern-Volmer Plots .......................S7

VI. Electrochemical Procedures and Data...........................................S8

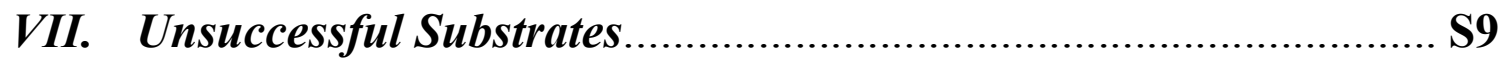

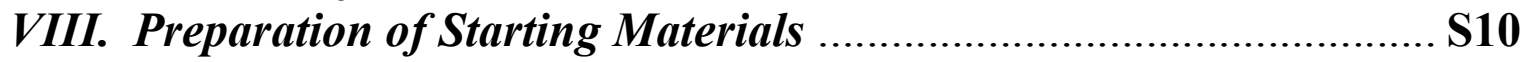

IX. Preparation of Products from Substrate Table ................................S24

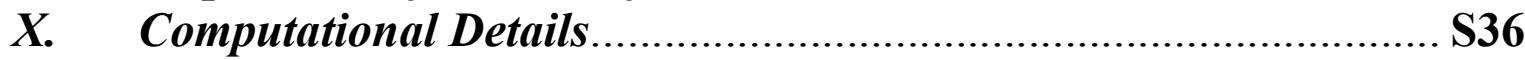

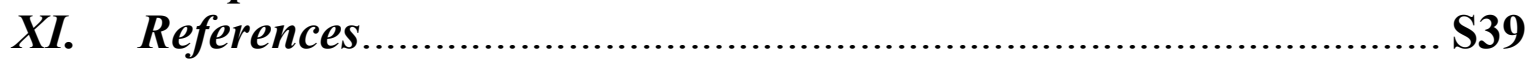

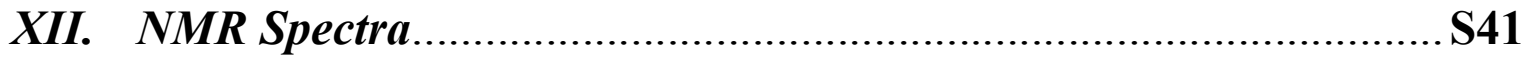




\section{General Information}

\section{Ia. General Reagent Information}

Solvents used in anhydrous reactions were purified by passing over activated alumina and storing under argon. Reagents were purchased from Sigma-Aldrich, Alfa Aesar, Acros Organics, Combi-Blocks, Oakwood Chemicals, Astatech, and TCI America and used as received, unless stated otherwise. n-Butyllithium (n-BuLi) was used as a $1.6 \mathrm{M}$ or $2.5 \mathrm{M}$ solution in hexanes (Aldrich), and stored at $4{ }^{\circ} \mathrm{C}$ and titrated prior to use. Organic solutions were concentrated under reduced pressure on a rotary evaporator using a water bath. Chromatographic purification of products was accomplished using forced-flow chromatography on 230-400 mesh silica gel. Preparative HPLC was carried out using an Agilent Technologies 1260 Infinity HPLC with a $21.2 \times 250 \mathrm{~mm}, 7 \mu \mathrm{m}$ pore size, ZORBAX Eclipse XDB-C18 Column. Eluents used were unmodified unless otherwise stated. Preparative thin-layer chromatography (PTLC) separations were carried out on $1000 \mu \mathrm{m}$ SiliCycle silica gel F-254 plates. Thin-layer chromatography (TLC) was performed on $250 \mu \mathrm{m}$ SiliCycle silica gel F-254 plates. Visualization of the developed chromatogram was performed by fluorescence quenching or staining using $\mathrm{KMnO}_{4}$, panisaldehyde, or ninhydrin stains. Solvent was degased by sonication under mild vacuum for 15 minutes. Photoredox catalysts 3DPAFIPN, 3DPA2FBN, 4CzIPN, 5CzBN, N-POX $\left(\mathrm{Ph}_{2}\right)_{2}$ were all prepared according to literature procedures ${ }^{1,2}$

\section{Ib. General Analytical Information}

Unless otherwise noted, all yields refer to chromatographically and spectroscopically ( ${ }^{1} \mathrm{H}$ NMR) homogenous materials. New compounds were characterized by NMR, IR, HRMS, and melting point (when solid). ${ }^{1} \mathrm{H}$ and ${ }^{13} \mathrm{C}$ NMR spectra were obtained from the Emory University NMR facility and recorded on a Bruker Avance III HD 600 equipped with cryo-probe (600 MHz), INOVA 600 (600 MHz), INOVA 500 (500 MHz), INOVA 400 (400 MHz), VNMR 400 (400 $\mathrm{MHz}$ ), or Mercury 300 (300 MHz), and are internally referenced to residual protio solvent signals. Data for ${ }^{1} \mathrm{H}$ NMR are reported as follows: chemical shift (ppm), multiplicity (s = singlet, $\mathrm{d}=$ doublet, $\mathrm{t}=$ triplet, $\mathrm{q}=$ quartet, $\mathrm{m}=$ multiplet, $\mathrm{dd}=$ doublet of doublets, $\mathrm{dt}=$ doublet of triplets, $\mathrm{ddd}=$ doublet of doublet of doublets, $\mathrm{dtd}=$ doublet of triplet of doublets, $\mathrm{b}=$ broad, etc.), coupling constant $(\mathrm{Hz})$, integration, and assignment, when applicable. Data for decoupled ${ }^{13} \mathrm{C}$ NMR are reported in terms of chemical shift and multiplicity when applicable. IR spectra were recorded on a Thermo Fisher DiamondATR and reported in terms of frequency of absorption $\left(\mathrm{cm}^{-1}\right)$. High resolution mass spectra were obtained through the use of an Agilent 6230 electrospray ionization time-of-flight (ESI-TOF) mass spectrometer. Gas Chromatography Mass Spectrometry (GC-MS) was performed on an Agilent 5977A mass spectrometer with an Agilent 7890A gas chromatography inlet. Liquid Chromatography Mass Spectrometry (LC-MS) was performed on an Agilent 6120 mass spectrometer with an Agilent 1220 Infinity liquid chromatography inlet. Preparative High Pressure Liquid chromatography (Prep-HPLC) was performed on an Agilent 1200 Infinity Series chromatograph using an Agilent Prep-C18 $30 \mathrm{x}$ $250 \mathrm{~mm} 10 \mu \mathrm{m}$ column, or an Agilent Prep-C18 21.2 x $100 \mathrm{~mm}, 5 \mu \mathrm{m}$ column. 


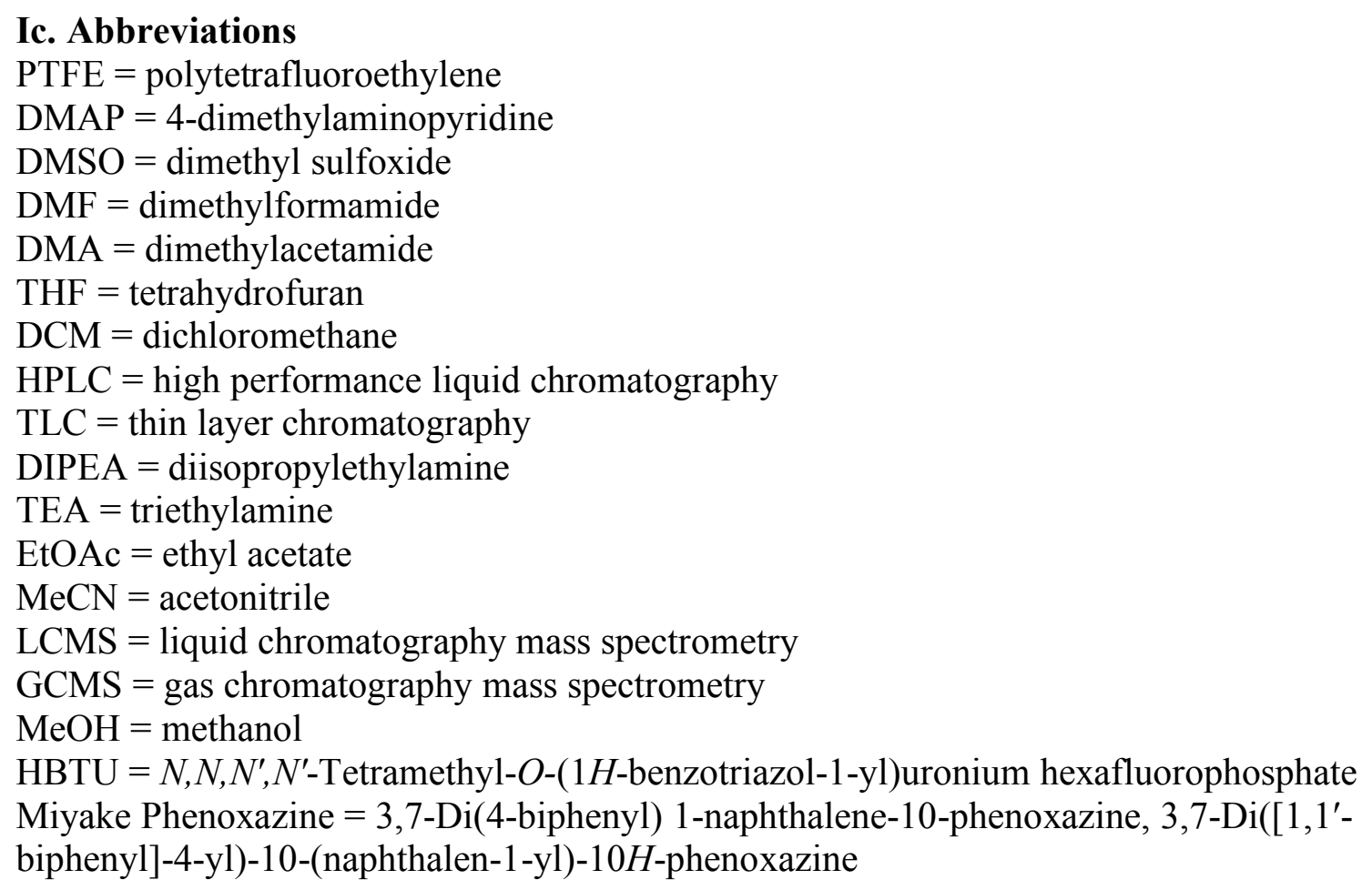

\section{General Procedures}

\section{IIa. General Procedure A}

A $20 \mathrm{~mL}$ screw-top test tube was charged with photocatalyst $(0.025 \mathrm{mmol}, 5 \mathrm{~mol} \%)$, and substrate $(0.5 \mathrm{mmol}, 1.0$ equiv). The tube was equipped with a stir bar was sealed with a PTFE/silicon septa. The atmosphere was exchanged by applying vacuum and backfilling with nitrogen (this process was conducted a total of three times). Under nitrogen atmosphere, separate degased solvent was added via syringe $\left(7.5 \mathrm{~mL}\right.$ of each $\mathrm{MeCN}$ and $\mathrm{H}_{2} \mathrm{O}$ to give a $0.03 \mathrm{M}$ solution), followed by DIPEA (3.0 equiv). The resulting mixture was stirred at 1400 RPM for 16 $\mathrm{h}$ under irradiation by blue LEDs, unless noted otherwise. The reaction was then extracted with ethyl acetate $(3 \mathrm{x})$, dried with $\mathrm{MgSO}_{4}$, and concentrated. The residue was purified on silica using the indicated solvent mixture as eluent to afford the title compound.

\section{IIb. General Procedure B}

A $20 \mathrm{~mL}$ screw-top test tube was charged with photocatalyst $(0.025 \mathrm{mmol}, 5 \mathrm{~mol} \%)$, and substrate $(0.5 \mathrm{mmol}, 1.0$ equiv). The tube was equipped with a stir bar was sealed with a $\mathrm{PTFE} /$ silicon septa. The atmosphere was exchanged by applying vacuum and backfilling with nitrogen (this process was conducted a total of three times). Under nitrogen atmosphere, separated degased solvent was added via syringe ( $7.5 \mathrm{~mL}$ of each $\mathrm{MeCN}$ and $\mathrm{H}_{2} \mathrm{O}$ to give a 0.03 M solution), followed by DIPEA (10.0 equiv). The resulting mixture was stirred at 1400 RPM for $16 \mathrm{~h}$ under irradiation by blue LEDs, unless noted otherwise. The reaction was then extracted with ethyl acetate $(3 \mathrm{x})$, dried with $\mathrm{MgSO}_{4}$, and concentrated. The residue was purified on silica using the indicated solvent mixture as eluent to afford the title compound. 


\section{Optimization Details}

\section{IIIa. Optimization Procedure}

An $8 \mathrm{~mL}$ screw-top test tube was charged with photocatalyst $(0.005 \mathrm{mmol}, 5 \mathrm{~mol} \%)$ and 3 (benzyloxy)-2-bromopyridine ( $0.1 \mathrm{mmol}, 1.0$ equiv). The tube was equipped with a stir bar and sealed with a PTFE/silicon septa. The atmosphere was exchanged by applying vacuum and backfilling with nitrogen (this process was conducted a total of three times). Under nitrogen atmosphere, separately degased solvent was added via syringe, followed by reductant. The resulting mixture was stirred at $800 \mathrm{RPM}$ for $16 \mathrm{~h}$ under irradiation by blue LEDs, unless noted otherwise. The reaction was then extracted with ethyl acetate $(3 \mathrm{x})$, washed with brine, dried with $\mathrm{MgSO}_{4}$, and concentrated. Deutro-chloroform with an internal standard of dibromomethane (7 $\mu \mathrm{L}, 0.1 \mathrm{mmol})$ was added. The sample was analyzed by ${ }^{1} \mathrm{H} \mathrm{NMR}(\mathrm{d}=5 \mathrm{~s})$, and the integral values were used to calculate the data given in Table S1.

\section{IIIb. Reaction Setup}

All photoredox reactions were set up on the bench top and conducted under nitrogen atmosphere while subject to irradiation from blue LEDs, unless stated otherwise (LED wholesalers PAR38 Indoor Outdoor 16-Watt LED Flood Light Bulb, Blue; or Hydrofarm ${ }^{\circledR}$ PPB1002 PowerPAR LED Bulb-Blue 15W/E27 (available from Amazon). Ambient temperature was maintained by using either a fan or compressed air line. Shown below is a photograph of the reaction setup, where the LED array was positioned approximately 6 inches above the test tubes containing reaction mixture. For convenience, a 3D printed reaction carousel was utilized, where up to 12 reactions could be conducted simultaneously.

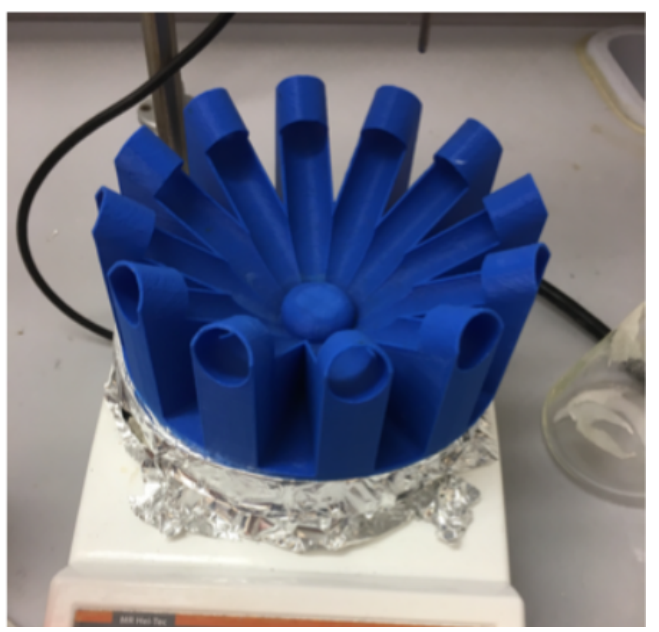

Reaction carousel

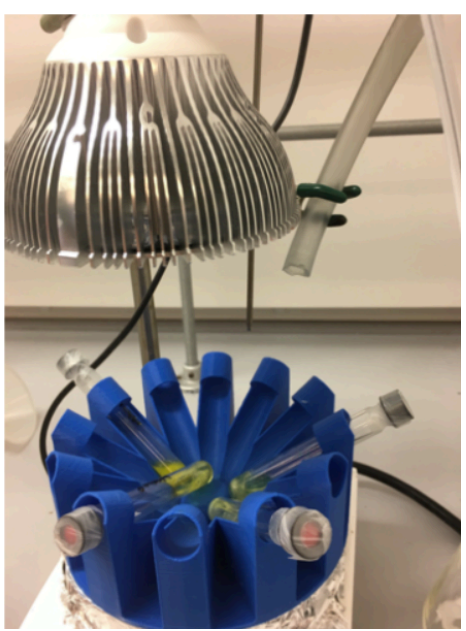

Positioning of LED array

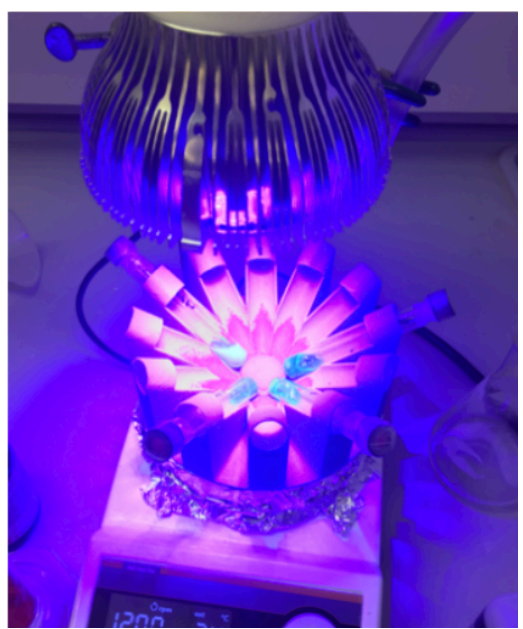

Reaction setup 


\section{Table S1: Optimization of Dearomative Hydroarylation Reaction}<smiles>Brc1ncccc1OCc1ccccc1</smiles>

S6

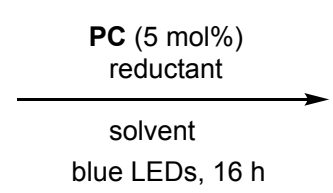

blue LEDs, $16 \mathrm{~h}$

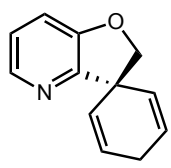

12

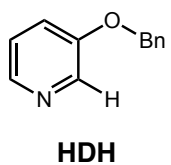

(Hydrodehalogenation)

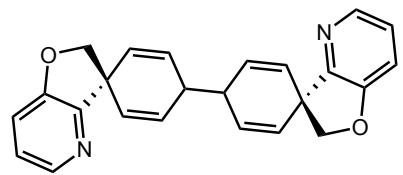

Dimer

\begin{tabular}{|c|c|c|c|c|c|c|c|c|}
\hline Entry & PC & Reductant (equiv) & $\%$ Water & Cosolvent ( $r x n$ conc) & S6 & 12 & HDH & Dimer \\
\hline 1 & 3DPAFIPN & tributylamine (3) & 10 & $\operatorname{DMF}(0.1 \mathrm{M})$ & 19 & 29 & 27 & 0 \\
\hline 2 & 3DPAFIPN & tributylamine (3) & 10 & $\mathrm{EtOH}(0.1 \mathrm{M})$ & 2 & 51 & 20 & 0 \\
\hline 3 & 3DPAFIPN & tributylamine (3) & 10 & $\operatorname{TFE}(0.1 \mathrm{M})$ & 0 & 57 & 7 & 15 \\
\hline 4 & 3DPAFIPN & tributylamine (3) & 10 & $\operatorname{DMSO}(0.1 \mathrm{M})$ & 11 & 43 & 7 & 0 \\
\hline 5 & 3DPAFIPN & tributylamine (3) & 10 & $\operatorname{MeCN}(0.1 \mathrm{M})$ & 0 & 60 & 19 & 0 \\
\hline 6 & 3DPAFIPN & tributylamine (3) & 50 & $\mathrm{MeCN}(0.1 \mathrm{M})$ & 0 & 71 & 14 & 0 \\
\hline 7 & 3DPAFIPN & tributylamine (3) & 80 & $\mathrm{MeCN}(0.1 \mathrm{M})$ & 0 & 39 & 66 & 0 \\
\hline 8 & 3DPAFIPN & DIPEA (3) & 0 & $\operatorname{MeCN}(0.03 \mathrm{M})$ & 6 & 68 & 13 & 8 \\
\hline 9 & 3DPAFIPN & DIPEA (3) & 50 & $\mathrm{MeCN}(0.1 \mathrm{M})$ & 0 & 81 & 21 & 0 \\
\hline 10 & 3DPAFIPN & DIPEA (3) & 50 & $\operatorname{MeCN}(0.03 M)$ & 5 & 86 & 6 & $\mathbf{0}$ \\
\hline 11 & $4 \mathrm{CzIPN}$ & DIPEA (3) & 50 & $\operatorname{MeCN}(0.03 \mathrm{M})$ & 46 & 49 & 5 & 0 \\
\hline 12 & $5 \mathrm{CzBN}$ & DIPEA (3) & 50 & $\operatorname{MeCN}(0.03 \mathrm{M})$ & 36 & 46 & 20 & 0 \\
\hline 13 & 3DPA2FBN & DIPEA (3) & 50 & $\operatorname{MeCN}(0.03 \mathrm{M})$ & 0 & 66 & 5 & 9 \\
\hline 14 & $\operatorname{Ir}(p p y)_{2}(d t b b p y) P F_{6}$ & DIPEA (3) & 50 & $\operatorname{MeCN}(0.03 \mathrm{M})$ & 14 & 66 & 15 & 0 \\
\hline 15 & $\operatorname{Ir}(\text { ppy })_{3}$ & DIPEA (3) & 50 & $\operatorname{MeCN}(0.03 \mathrm{M})$ & 17 & 31 & 8 & 14 \\
\hline $16^{\mathrm{a}}$ & 3DPAFIPN & DIPEA (3) & 50 & $\operatorname{MeCN}(0.03 \mathrm{M})$ & 49 & 44 & 5 & 0 \\
\hline 17 & 3DPAFIPN & none & 50 & $\operatorname{MeCN}(0.03 \mathrm{M})$ & 100 & 0 & 0 & 0 \\
\hline 18 & none & DIPEA (3) & 50 & $\operatorname{MeCN}(0.03 \mathrm{M})$ & 100 & 0 & 0 & 0 \\
\hline $19^{\mathrm{b}}$ & 3DPAFIPN & DIPEA (3) & 50 & $\operatorname{MeCN}(0.03 \mathrm{M})$ & 100 & 0 & 0 & 0 \\
\hline
\end{tabular}

${ }^{\mathrm{a}}$ Reaction conducted open to air (typically conducted after degassing, under $\mathrm{N}_{2}$ ). ${ }^{\mathrm{b}}$ Reaction conducted in the dark (tube wrapped in aluminum foil). 
IV. Example of Selectivity: Crude ${ }^{1} \mathrm{H}$ NMR to Give Product 5
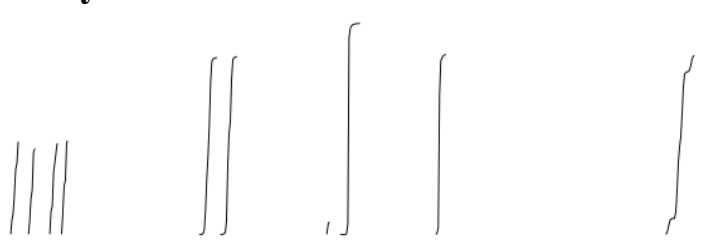

$\mathrm{CH}_{2} \mathrm{Br}_{2}(0.1 \mathrm{mmol}), 2 \mathrm{H}$

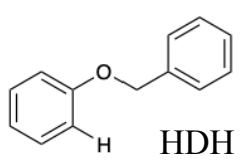

6

Desired spirocyclic product 5

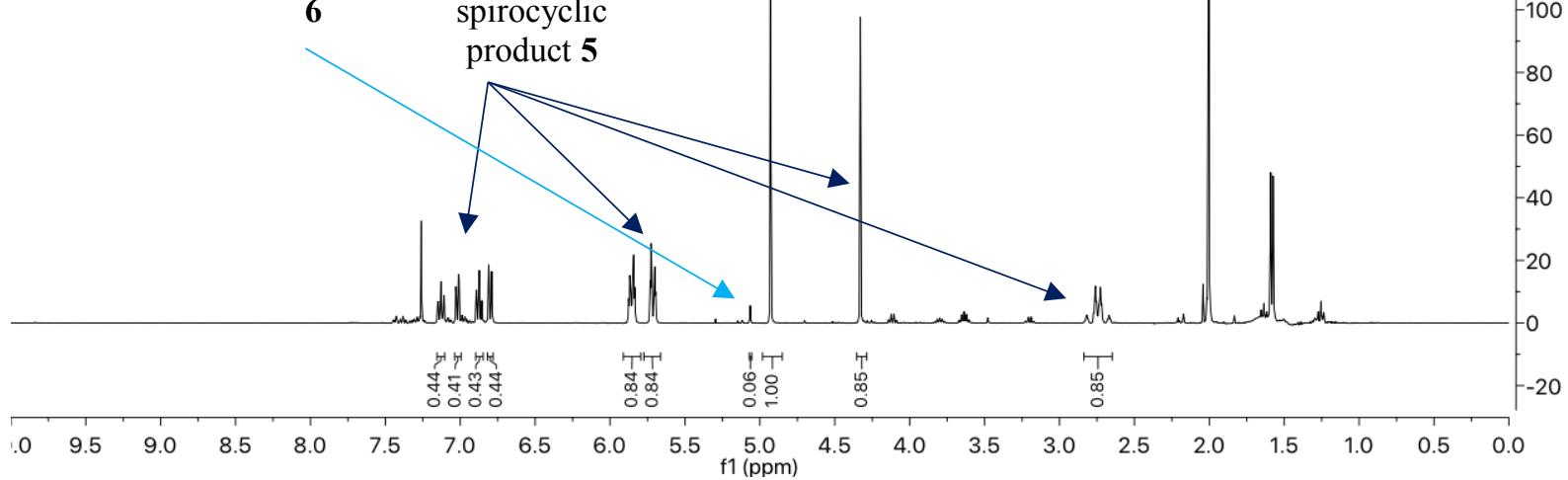

1-(benzyloxy)-2-iodobenzene $(0.1 \mathrm{mmol})$ was subjected to General Conditions A. The reaction was then extracted with ethyl acetate $(3 \mathrm{x})$, dried with $\mathrm{MgSO}_{4}$, and concentrated. Deutro-chloroform with an internal standard of dibromomethane $(7 \mu \mathrm{L}, 0.1 \mathrm{mmol})$ was added. The sample was analyzed by ${ }^{1} \mathrm{H}$ NMR $(\mathrm{d}=5 \mathrm{~s})$, and the integral values are shown in the crude NMR above. NMR was compared to (and was consistent with) reported literature values: J. Org. Chem. 2008, 73 (18), 7145-7152. 


\section{Fluorescence Quenching and Stern-Volmer Plots}

All fluorescence measurements were recorded using a Horiba Scientific Dual-FL Fluorometer. Quenching studies were conducted in $\mathrm{MeCN}$ at $20 \pm 0.5^{\circ} \mathrm{C}$ (Peltier temperature controller) with a photocatalyst (3DPAFIPN) concentration of $9.01 * 10^{-6} \mathrm{M}$. Samples were prepared in Starna quartz cuvettes (3-Q-10-GL14-S) with septum seal caps. Dry $\mathrm{N}_{2}$ was bubbled through the prepared sample for 4 minutes before analysis. Raw fluorescence intensity was measured at $1=$ $542 \mathrm{~nm}$ after excitation at $1=380 \mathrm{~nm}$ in the quartz cuvettes with a path length of $1 \mathrm{~cm}$ and 0.1 second integration. Measurements of the quenchers shown were plotted using Igor Pro 8; data points were fit with a linear trend line.
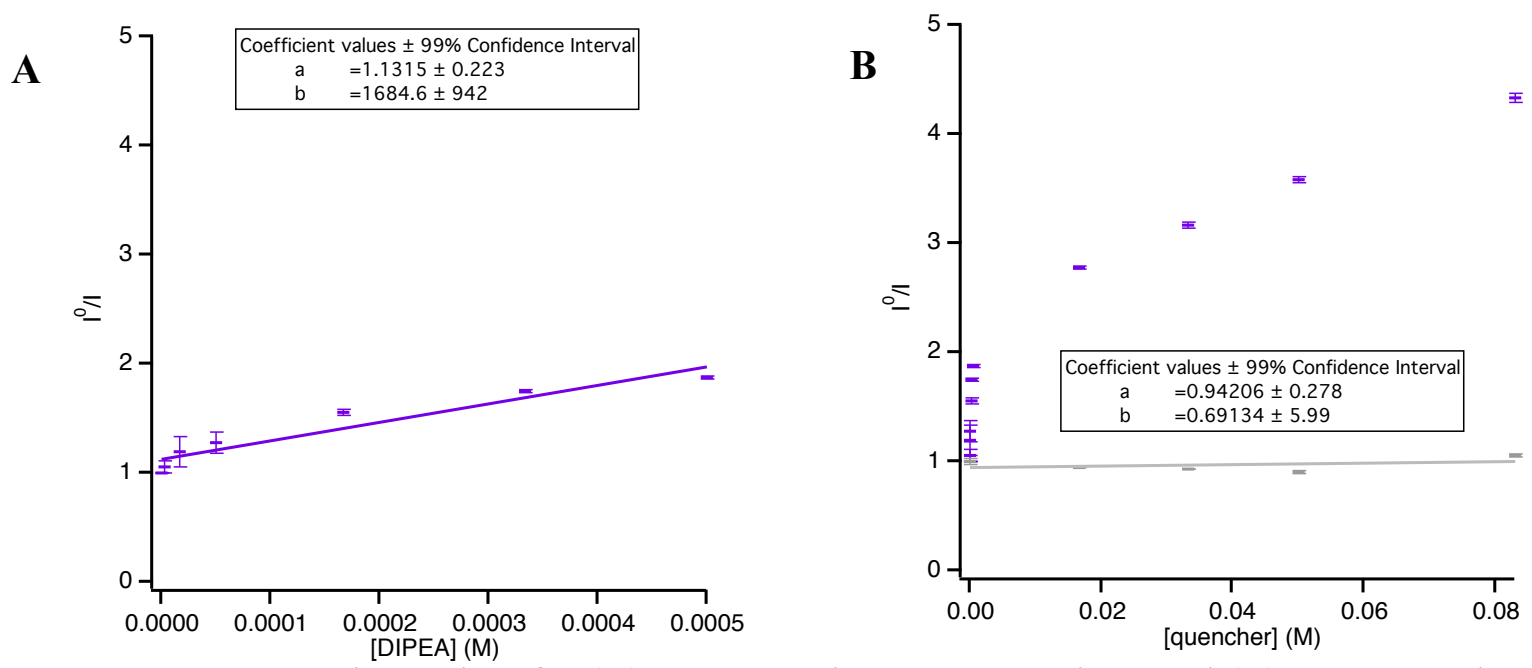

Figure S1: Stern-Volmer plots for (A) DIPEA at low concentrations and (B) DIPEA and 3(benzyloxy)-2-bromopyridine up to $\sim 10,000$ equivalents with respect to photocatalyst 3DPAFIPN.

Table S2: Fluorescence Quenching Data

\begin{tabular}{ccccc}
\hline Compound (Quencher) & [Quencher] $\mathbf{( M )}$ & $\mathbf{I} / \mathbf{I}$ & Equiv vs PC & Coefficients \\
\hline Diisopropylethylamine & 0 & 1 & 0 & $\mathrm{y}=\mathrm{a}+\mathrm{bx}$ \\
Diisopropylethylamine & $3.3 * 10^{-6}$ & 1.06 & 0.4 & $\mathrm{a}=1.1 \pm 0.2$ \\
Diisopropylethylamine & $1.67 * 10^{-5}$ & 1.20 & 1.9 & $\mathrm{~b}=1684 \pm 942$ \\
Diisopropylethylamine & $5.0^{*} 10^{-5}$ & 1.27 & 5.6 & \\
Diisopropylethylamine & $1.67 * 10^{-4}$ & 1.56 & 19 & $\pm 99 \% \mathrm{CI}$ \\
Diisopropylethylamine & $3.33^{*} 10^{-4}$ & 1.76 & 37 & \\
Diisopropylethylamine & $5.0^{*} 10^{-4}$ & 1.88 & 55 & \\
Diisopropylethylamine & $1.67 * 10^{-2}$ & 2.77 & 1854 & \\
Diisopropylethylamine & $3.33^{*} 10^{-2}$ & 3.16 & 3696 & \\
Diisopropylethylamine & $5.0^{*} 10^{-2}$ & 3.59 & 5549 & \\
Diisopropylethylamine & $8.3 * 10^{-2}$ & 4.33 & 9212 & \\
\hline 3-(benzyloxy)-2-bromopyridine & 0 & 1 & 0 & $\mathrm{y}=\mathrm{a}+\mathrm{bx}$ \\
3-(benzyloxy)-2-bromopyridine & $1.67 * 10^{-2}$ & 0.94 & 1854 & $\mathrm{a}=0.94 \pm 0.28$ \\
3-(benzyloxy)-2-bromopyridine & $3.33 * 10^{-2}$ & 0.94 & 3696 & $\mathrm{~b}=0.69 \pm 5.99$ \\
3-(benzyloxy)-2-bromopyridine & $5.0 * 10^{-2}$ & 0.91 & 5549 & \\
3-(benzyloxy)-2-bromopyridine & $8.3 * 10^{-2}$ & 1.06 & 9212 & $\pm 99 \% \mathrm{CI}$ \\
\hline
\end{tabular}




\section{Evaluation of Electrochemical Hydroarylation}

To an ElectraSyn vial charged with stir bar was added 3-(benzyloxy)-2-bromopyridine (0.2 mmol, 1 equiv), electrolyte (to make the indicated concentration), and solvent ( $6 \mathrm{~mL}$ ) An IKA $\mathrm{Mg}$ (anode) and $\mathrm{Pt}$ (cathode) plate electrodes were connected to an ElectraSyn vial cap. The ElectraSyn was setup as follows: New exp. $>$ constant current $>\mathbf{X ~ m A ~ ( c u r r e n t ) ~}>$ no ref. electrode $>$ total charge $>0.2 \mathrm{mmol}, 3 \mathrm{~F} / \mathrm{mol}>$ no alternating polarity $>$ start. The reaction was allowed to run with stirring until the ElectraSyn had measured $3 \mathrm{~F} / \mathrm{mol}$ input. The reaction was then concentrated. Deutro-chloroform with an internal standard of dibromomethane $(7 \mu \mathrm{L}, 0.1$ mmol) was added. The sample was analyzed by ${ }^{1} \mathrm{H}$ NMR $(d=5 \mathrm{~s})$, and the integral values were used to calculate the data given in Table S3.

Table S3: Results from Hydroarylation Under Electrochemical Conditions

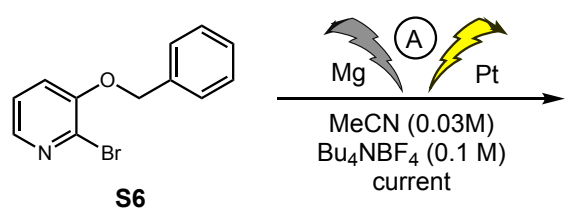

\begin{tabular}{ccc}
\hline entry & current & S6 \\
1 & $2 \mathrm{~mA}$ & 100 \\
2 & $5 \mathrm{~mA}$ & 71 \\
3 & $10 \mathrm{~mA}$ & 28 \\
4 & $50 \mathrm{~mA}$ & 29
\end{tabular}

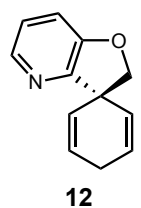<smiles>Oc1ncccc1OCc1ccccc1</smiles>

$$
\begin{gathered}
\text { HDH } \\
0 \\
30 \\
60 \\
63
\end{gathered}
$$




\section{Unsuccessful Substrates in Dearomatization}

Shown below are substrate classes that did not afford the desired spirocyclic products under standard conditions. The most pronounced limitation here involves electron-deficient aromatics, which are highlighted in gray. In these specific cases, linker fragmentation was the dominant pathway where the observed products arise from arene radical anion formation followed by mesolytic cleavage. In addition, the secondary amide and ester based substrates did not undergo cyclization. Rather, the primary reaction outcome here was hydrodehalogenation, presumably the result of energetic preferences for the linear conformation.

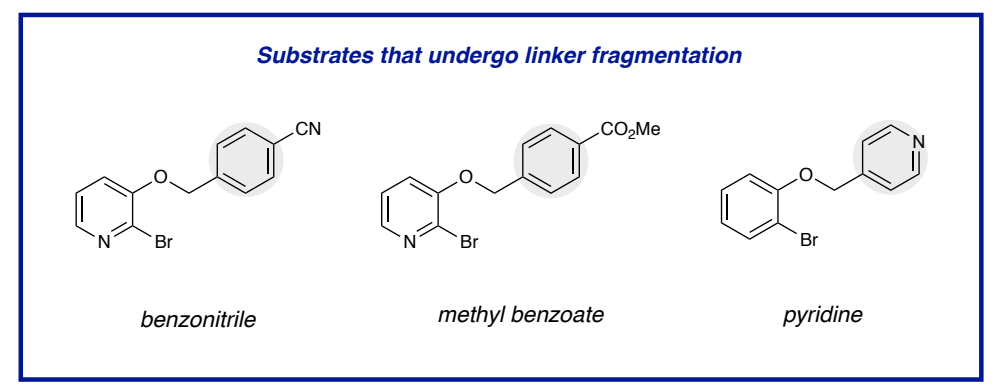

Substrates that undergo hydrodehalogenation
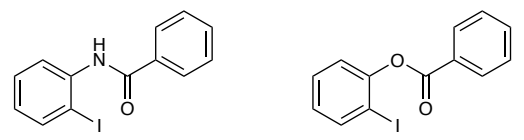

secondary amides linkers

ester linkers<smiles>Cc1ccc(C)cc1</smiles>

Proposed mechanism for linker fragmentation with electron deficient aromatics

observed products

Figure S2. Unsuccessful Dearomatization Substrate Classes 


\section{Preparation of Starting Materials}<smiles>COS(=O)(=O)Nc1ccccc1I</smiles>

\section{$\mathrm{N}$-(2-iodophenyl)methanesulfonamide (S1)}

To a solution of 2-iodoaniline $(572 \mathrm{mg}, 2.6 \mathrm{mmol}, 1$ equiv) in dichloromethane $(25 \mathrm{~mL})$ was added methanesulfonyl chloride $(250 \mu \mathrm{L}, 3.2 \mathrm{mmol}, 1.2$ equiv) dropwise via syringe, followed by pyridine $(250 \mu \mathrm{L}, 2.8 \mathrm{mmol}, 1.1$ equiv). The resulting mixture was stirred at room temperature for $4 \mathrm{~h}$ and concentrated. The resulting residue was purified on silica gel $(20-50 \%$ eluent) to afford the title compound as a white solid (770 $\mathrm{mg},>99 \%)$.

${ }^{1} \mathbf{H}$ NMR $\left(399 \mathrm{MHz}, \mathrm{CDCl}_{3}\right) \delta 7.80(\mathrm{dd}, J=8.0,1.5 \mathrm{~Hz}, 1 \mathrm{H}), 7.61(\mathrm{dd}, J=8.2,1.5 \mathrm{~Hz}, 1 \mathrm{H}), 7.35$ (tdd, $J=8.0,1.5,0.5 \mathrm{~Hz}, 1 \mathrm{H}), 6.91$ (ddd, $J=8.0,7.4,1.5 \mathrm{~Hz}, 1 \mathrm{H}), 6.67$ (bs, 1H), 2.99 (s, 3H).

${ }^{13} \mathrm{C}$ NMR $\left(100 \mathrm{MHz}, \mathrm{CDCl}_{3}\right) \delta 139.4,137.6,129.9,127.3,122.6,92.3,40.2$.

LRMS (APCI) m/z: [M-H] $]^{-}$calc'd. for $\mathrm{C}_{7} \mathrm{H}_{7} \mathrm{INO}_{2} \mathrm{~S}$, 295.9; found 295.8

${ }^{1} \mathrm{H}$ NMR spectrum is consistent with reported values ${ }^{3}$<smiles>CN(Cc1ccccc1)c1ccccc1I</smiles>

\section{$\mathrm{N}$-benzyl- $\mathrm{N}$-(2-iodophenyl)methanesulfonamide (S2)}

A $20 \mathrm{~mL}$ screw-top vial was charged with $\mathrm{N}$-(2-iodophenyl)methanesulfonamide (S1), (459 mg, $1.6 \mathrm{mmol}, 1.0$ equiv) and $\mathrm{K}_{2} \mathrm{CO}_{3}(365 \mathrm{mg}, 2.6 \mathrm{mmol}, 1.6$ equiv). DMF was added (15 mL) followed by benzyl bromide $(450 \mu \mathrm{L}, 3.7 \mathrm{mmol}, 2.3$ equiv). The reaction was stirred overnight (ca. $16 \mathrm{~h}$ ) at room temperature, then heated to $60^{\circ} \mathrm{C}$ and heated until starting material was consumed (as determined by LCMS). The reaction was cooled to room temperature and then partitioned between EtOAc and water. The organic layer was washed with brine 3x, dried with $\mathrm{MgSO}_{4}$ and purified on silica gel (10-50\% eluent) to afford the title compound as a colorless oil (394 mg, 66\%).

${ }^{1} \mathbf{H}$ NMR $\left(399 \mathrm{MHz}, \mathrm{CDCl}_{3}\right) \delta 7.89(\mathrm{~d}, J=7.9 \mathrm{~Hz}, 1 \mathrm{H}), 7.25(\mathrm{~s}, 6 \mathrm{H}), 7.03(\mathrm{~d}, J=7.9 \mathrm{~Hz}, 1 \mathrm{H})$, $6.99(\mathrm{t}, J=7.6 \mathrm{~Hz}, 1 \mathrm{H}), 5.05(\mathrm{~d}, J=14.6 \mathrm{~Hz}, 1 \mathrm{H}), 4.54(\mathrm{~d}, J=14.6 \mathrm{~Hz}, 1 \mathrm{H}), 3.04(\mathrm{~s}, 3 \mathrm{H})$.

${ }^{13}$ C NMR $\left(100 \mathrm{MHz}, \mathrm{CDCl}_{3}\right) \delta 140.7,140.4,135.4,133.1,130.2,129.7,129.0,128.5,128.2$, 101.0, 54.9, 41.8 .

LRMS (APCI) m/z: $[\mathrm{M}+\mathrm{H}]^{+}$calc'd. for $\mathrm{C}_{14} \mathrm{H}_{15} \mathrm{INO}_{2} \mathrm{~S}, 387.9$; found 387.7<smiles>O=C(Nc1ccccc1Br)c1ccccc1</smiles>

tert-butyl (2-bromophenyl)carbamate (S3): In a round bottom flask, 2-bromoaniline (15 g, 88 mmol, 1.0 equiv) was dissolved in DCM $(800 \mathrm{~mL})$ and cooled to $0{ }^{\circ} \mathrm{C}$. Di-tert-butyl decarbonate (43 g, $195 \mathrm{mmol}, 2.2$ equiv) was added slowly to the reaction over the course of 30 minutes. Dimethylaminopyridine ( $1.8 \mathrm{~g}, 15 \mathrm{mmol}, 0.2$ equiv) was then added slowly to the reaction mixture (caution: on this large scale significant exotherm and evolution of $\mathrm{CO}_{2}$ is possible.). The resulting mixture was stirred until consumption of the starting material was detected by TLC. The reaction was then poured onto water, washed with $\mathrm{NaHCO}_{3}$, and extracted with EtOAc x3. The combined organic layers were dried with $\mathrm{MgSO}_{4}$. The crude oil was identified as the di-boc 
product by ${ }^{1} \mathrm{H}$ NMR. One Boc was removed by stirring the crude oil in a dilute solution of TFA in DCM at $0{ }^{\circ} \mathrm{C}$. This reaction was monitored carefully by TLC until the complete removal of one boc was detected. The reaction was then basified, poured onto water and extracted with EtOAc x3. The crude oil was purified on silica (10-30\% EtOAc/Hex eluent) to afford the title product as a colorless oil ( $19 \mathrm{~g}, 80 \%$ over 2 steps).

${ }^{1} \mathbf{H}$ NMR $\left(400 \mathrm{MHz}, \mathrm{CDCl}_{3}\right) \delta 8.13(\mathrm{~d}, J=8.4 \mathrm{~Hz}, 1 \mathrm{H}), 7.48(\mathrm{~d}, J=8.0,1.7 \mathrm{~Hz}, 1 \mathrm{H}), 7.32-7.16$ $(\mathrm{m}, 1 \mathrm{H}), 6.97(\mathrm{bs}, 1 \mathrm{H}), 6.88(\mathrm{t}, J=7.7 \mathrm{~Hz}, 1 \mathrm{H}), 1.52(\mathrm{~s}, 9 \mathrm{H})$.

${ }^{1} \mathrm{H}$ NMR spectrum is consistent with reported values ${ }^{4}$<smiles>O=[N+]([O-])c1ccccc1Cc1ccccc1</smiles>

tert-butyl benzyl(2-bromophenyl)carbamate (S4): In a round bottom flask under nitrogen, sodium hydride as a $60 \%$ dispersion in mineral oil $(180 \mathrm{mg}, 4.5 \mathrm{mmol}, 1.3$ equiv) was suspended in DMF $(20 \mathrm{~mL})$ and cooled to $0{ }^{\circ} \mathrm{C}$. $\mathbf{S 3}$ as a solution in DMF $(976 \mathrm{mg}, 3.6 \mathrm{mmol}, 1.0$ equiv in about $10 \mathrm{~mL}$ DMF) was added dropwise to the sodium hydride suspension and stirred for 30 minutes before the addition of benzyl bromide ( $513 \mu \mathrm{L}, 4.3 \mathrm{mmol}, 1.2$ equiv). The reaction was removed from the ice bath, and after reacting for $4.5 \mathrm{~h}$ was quenched with methanol then water at $0{ }^{\circ} \mathrm{C}$. The resulting mixture was diluted with ethyl acetate and washed with brine $3 \mathrm{x}$. The organic layer was dried with $\mathrm{MgSO}_{4}$, concentrated in vacuo, and purified on silica gel (5\% EtOAc/Hex eluent) to afford the title compound as a colorless oil ( $238 \mathrm{mg},>99 \%)$.

${ }^{1} \mathbf{H}$ NMR $\left(500 \mathrm{MHz}, \mathrm{CDCl}_{3}, 60^{\circ} \mathrm{C}\right) \delta 7.59(\mathrm{bd}, J=7.9 \mathrm{~Hz}, 1 \mathrm{H}), 7.26(\mathrm{bm}, 5 \mathrm{H}), 7.10(\mathrm{bm}, 2 \mathrm{H})$, $6.84(\mathrm{bs}, 1 \mathrm{H}), 5.21(\mathrm{~s}, 1 \mathrm{H}), 4.23(\mathrm{~d}, J=14.9 \mathrm{~Hz}, 1 \mathrm{H}), 1.44(\mathrm{bm}, J=61.2 \mathrm{~Hz}, 9 \mathrm{H})$.

${ }^{13} \mathrm{C}$ NMR $\left(151 \mathrm{MHz}, \mathrm{CDCl}_{3}, 60{ }^{\circ} \mathrm{C}\right) \delta 154.4,141.2,137.9,133.1,130.9,128.9,128.4,128.2$, 127.6, 127.3, 123.8, 80.5, 52.7, 28.2.

LRMS (APCI) m/z: $\left[\mathrm{M}-\mathrm{C}_{4} \mathrm{H}_{9} \mathrm{H}+\mathrm{H}\right]^{+}$calc'd. for $\mathrm{C}_{14} \mathrm{H}_{12} \mathrm{BrNO}_{2}$, 305.0; found 305.8 .<smiles>O=C(Nc1ccccc1I)c1ccccc1</smiles>

$N$-(2-iodophenyl)benzamide (S5): To a solution of 2-iodoaniline (641 mg, $2.9 \mathrm{mmol}, 1.0$ equiv) in DCM $(30 \mathrm{~mL})$ was added benzoyl chloride $(375 \mu \mathrm{L}, 3.2 \mathrm{mmol}, 1.1$ equiv) dropwise via syringe, followed by triethylamine ( $500 \mu \mathrm{L}, 3.6 \mathrm{mmol}, 1.2$ equiv). The resulting mixture was stirred at room temperature for $4 \mathrm{~h}$, quenched with methanol, and concentrated. The resulting solid was purified on silica gel (10-20\% eluent) to afford the title compound as a white solid. (945 mg, >99\%).

${ }^{1}$ H NMR $\left(399 \mathrm{MHz}, \mathrm{CDCl}_{3}\right) \delta 8.42(\mathrm{dd}, J=8.2,1.6 \mathrm{~Hz}, 1 \mathrm{H}), 8.30(\mathrm{bs}, 1 \mathrm{H}), 8.01-7.88(\mathrm{~m}, 2 \mathrm{H})$, 7.79 (dd, $J=8.0,1.5 \mathrm{~Hz}, 1 \mathrm{H}), 7.61-7.45(\mathrm{~m}, 3 \mathrm{H}), 7.37$ (ddd, $J=8.1,7.4,1.5 \mathrm{~Hz}, 1 \mathrm{H}), 6.86(\mathrm{td}$, $J=7.7,1.6 \mathrm{~Hz}, 1 \mathrm{H})$.

${ }^{13} \mathbf{C}$ NMR $\left(100 \mathrm{MHz}, \mathrm{CDCl}_{3}\right) \delta 165.3,138.8,138.3,134.5,132.2,129.4,128.9,127.2,126.1$, 121.9, 90.4.

LRMS (APCI) m/z: $[\mathrm{M}+\mathrm{H}]^{+}$calc'd. for $\mathrm{C}_{13} \mathrm{H}_{11} \mathrm{INO}, 323.9$; found 323.7 
<smiles>O=C(c1ccccc1)N(c1ccccc1)c1ccccc1I</smiles>

$\boldsymbol{N}$-(2-iodophenyl)- $\boldsymbol{N}$-methylbenzamide (S6): In a vial under nitrogen, sodium hydride as a $60 \%$ dispersion in mineral oil (120 mg, $3.0 \mathrm{mmol}, 2.0$ equiv) was suspended in DMF (15 mL) and cooled to $0{ }^{\circ} \mathrm{C}$. $\mathbf{S 5}$ as a solution in DMF (476 mg, $1.5 \mathrm{mmol}, 1.0$ equiv in about $5 \mathrm{~mL}$ DMF) was added to the sodium hydride suspension and stirred for 30 minutes before the addition of methyl iodide (140 $\mu \mathrm{L}, 2.2 \mathrm{mmol}, 1.5$ equiv). The reaction was removed from the ice bath, and after reacting for $1.5 \mathrm{~h}$ was quenched with methanol then water at $0{ }^{\circ} \mathrm{C}$. The resulting mixture was diluted with ethyl acetate and washed with brine $3 \mathrm{x}$. The organic layer was dried with $\mathrm{MgSO}_{4}$, concentrated in vacuo, and purified on silica gel (10-25\% EtOAc/Hex eluent) to afford the title compound as a white solid (312 $\mathrm{mg}, 62 \%)$.

${ }^{1} \mathbf{H}$ NMR $\left(399 \mathrm{MHz}, \mathrm{CDCl}_{3}\right) \delta 7.75(\mathrm{dd}, J=8.0,1.4 \mathrm{~Hz}, 1 \mathrm{H}), 7.43-7.27(\mathrm{~m}, 2 \mathrm{H}), 7.20-7.01$ $(\mathrm{m}, 5 \mathrm{H}), 6.85(\mathrm{td}, J=7.6,1.7 \mathrm{~Hz}, 1 \mathrm{H}), 3.35(\mathrm{~s}, 3 \mathrm{H})$.

${ }^{13}$ C NMR $\left(100 \mathrm{MHz}, \mathrm{CDCl}_{3}\right) \delta 170.8,146.9,140.1,135.6,130.1,129.8,129.3,129.1,128.3$, 127.6, 99.1, 37.5.

LRMS (APCI) m/z: $[\mathrm{M}+\mathrm{H}]^{+}$calc'd. for $\mathrm{C}_{14} \mathrm{H}_{13} \mathrm{INO}, 338.0$; found 337.7

${ }^{1} \mathrm{H}$ NMR spectrum is consistent with reported values ${ }^{5}$<smiles>Brc1ncccc1OCc1ccccc1</smiles>

3-(benzyloxy)-2-bromopyridine (S7): A round bottom flask was charged with 2-bromo-3hydroxypyridine $\left(5.0 \mathrm{~g}, 29 \mathrm{mmol}, 1.0\right.$ equiv) and $\mathrm{K}_{2} \mathrm{CO}_{3}(8.0 \mathrm{~g}, 58 \mathrm{mmol}, 2.0$ equiv). DMF (100 $\mathrm{mL})$ was added, followed by benzyl bromide $(3.7 \mathrm{~mL}, 31 \mathrm{mmol}, 1.1$ equiv). The reaction was heated to $80{ }^{\circ} \mathrm{C}$ and stirred for $16 \mathrm{~h}$. The reaction was cooled to room temperature and then partitioned between EtOAc and water. The organic layer was washed with brine 3x, dried with $\mathrm{MgSO}_{4}$ and purified on silica gel (20-50\% EtOAc/hexanes eluent) to afford the title compound as a white solid $(7.5 \mathrm{~g}, 99 \%)$.

${ }^{1} \mathbf{H}$ NMR $\left(400 \mathrm{MHz}, \mathrm{CDCl}_{3}\right) \delta 7.96(\mathrm{dd}, J=3.8,2.4 \mathrm{~Hz}, 1 \mathrm{H}), 7.47-7.27(\mathrm{~m}, 5 \mathrm{H}), 7.18-7.09$ $(\mathrm{m}, 2 \mathrm{H}), 5.15(\mathrm{~s}, 2 \mathrm{H})$.

${ }^{13} \mathbf{C}$ NMR $\left(126 \mathrm{MHz}, \mathrm{CDCl}_{3}\right) \delta 152.0,141.6,135.5,133.3,128.7,128.3,127.0,123.3,120.5$, 70.9 .

LRMS (APCI) m/z: $[\mathrm{M}+\mathrm{H}]^{+}$calc'd. for $\mathrm{C}_{12} \mathrm{H}_{11} \mathrm{BrNO}$, 264.0; found 263.8<smiles>CC(Oc1cccnc1Br)c1ccccc1</smiles>

( \pm ) 2-bromo-3-(1-phenylethoxy)pyridine (S8): A round bottom flask was charged with 2bromo-3-hydroxypyridine (522 mg, $3.0 \mathrm{mmol}$, 1.0 equiv) and $\mathrm{K}_{2} \mathrm{CO}_{3}(829 \mathrm{mg}, 6.0 \mathrm{mmol}, 2.0$ equiv). MeCN (15 mL) was added, followed by (1-bromoethyl)benzene $(0.41 \mathrm{~mL}, 3.0 \mathrm{mmol}, 1.0$ equiv). The reaction was heated to $60^{\circ} \mathrm{C}$ and stirred for $18 \mathrm{~h}$. The reaction was cooled to room temperature, diluted with water, and extracted with EtOAc 3x. The organic layer was washed 
with brine, dried with $\mathrm{MgSO}_{4}$, and concentrated in vacuo to afford the title compound as a colorless oil (834 mg, $>99 \%)$.

${ }^{1} \mathbf{H}$ NMR $\left(600 \mathrm{MHz}, \mathrm{CDCl}_{3}\right) \delta 7.90(\mathrm{dt}, J=4.6,1.3 \mathrm{~Hz}, 1 \mathrm{H}), 7.41-7.37(\mathrm{~m}, 2 \mathrm{H}), 7.35(\mathrm{tt}, J=$ 6.5, 1.0 Hz, 2H), $7.31-7.24(\mathrm{~m}, 1 \mathrm{H}), 7.01(\mathrm{ddt}, J=8.2,4.6,1.2 \mathrm{~Hz}, 1 \mathrm{H}), 6.99-6.95(\mathrm{~m}, 1 \mathrm{H})$, $5.35(\mathrm{q}, J=6.4 \mathrm{~Hz}, 1 \mathrm{H}), 1.72(\mathrm{dd}, J=6.4,1.1 \mathrm{~Hz}, 3 \mathrm{H})$.

${ }^{13} \mathbf{C}$ NMR $\left(151 \mathrm{MHz}, \mathrm{CDCl}_{3}\right) \delta 151.4,141.5,141.3,133.8,128.9,128.0,125.6,123.2,121.9$, 77.8, 24.4.

LRMS (APCI) m/z: $[\mathrm{M}+\mathrm{H}]^{+}$calc'd. for $\mathrm{C}_{13} \mathrm{H}_{13} \mathrm{BrNO}, 278.0$; found 277.8 .<smiles>Brc1ncccc1OCCc1ccccc1</smiles>

2-bromo-3-phenethoxypyridine (S9): A 20mL screw-top vial was charged with 2-bromo-3hydroxypyridine (452 mg, $2.6 \mathrm{mmol}, 1.0$ equiv) and $\mathrm{K}_{2} \mathrm{CO}_{3}(716 \mathrm{mg}, 5.1 \mathrm{mmol}, 2.0$ equiv). DMF $(15 \mathrm{~mL})$ was added, followed by 2 (bromoethyl)benzene $(380 \mu \mathrm{L}, 2.9 \mathrm{mmol}, 1.1$ equiv). The reaction was heated to $80{ }^{\circ} \mathrm{C}$ and stirred for $16 \mathrm{~h}$. The reaction was cooled to room temperature and then partitioned between EtOAc and water. The organic layer was washed with brine $3 \mathrm{x}$, dried with $\mathrm{MgSO}_{4}$ and purified on silica gel (20-60\% EtOAc/hexanes eluent) to afford the title compound as a white solid (378 $\mathrm{mg}, 52 \%)$.

${ }^{1} \mathbf{H}$ NMR $\left(399 \mathrm{MHz}, \mathrm{CDCl}_{3}\right) \delta 7.93(\mathrm{dd}, J=4.6,1.6 \mathrm{~Hz}, 1 \mathrm{H}), 7.34-7.31(\mathrm{~m}, 4 \mathrm{H}), 7.27-7.22$ $(\mathrm{m}, 1 \mathrm{H}), 7.14(\mathrm{dd}, J=8.1,4.6 \mathrm{~Hz}, 1 \mathrm{H}), 7.04(\mathrm{dd}, J=8.2,1.5 \mathrm{~Hz}, 1 \mathrm{H}), 4.18(\mathrm{t}, J=6.8 \mathrm{~Hz}, 2 \mathrm{H})$, $3.15(\mathrm{t}, J=6.8 \mathrm{~Hz}, 2 \mathrm{H})$.

${ }^{1} \mathrm{H}$ NMR spectrum is consistent with reported values ${ }^{6}$<smiles>O=C(Nc1cccc([N+](=O)[O-])c1Br)c1ccccc1</smiles>

N-(2-bromo-3-methylphenyl)benzamide (S10): To a solution of 2-bromo-3-methylaniline (0.41 mL, $3.3 \mathrm{mmol}, 1.1$ equiv) in DCM $(30 \mathrm{~mL})$ was added benzoyl chloride $(0.35 \mathrm{~mL}, 3.0$ mmol, 1.0 equiv) dropwise via syringe, followed by triethylamine $(0.46 \mathrm{~mL}, 3.3 \mathrm{mmol}, 1.1$ equiv). The resulting mixture was stirred at room temperature for $22 \mathrm{~h}$, washed with $1 \mathrm{M} \mathrm{HCl}$ (aq), dried over $\mathrm{MgSO}_{4}$, and concentrated in vacuo to afford the title compound as a white solid. (732 mg, 84\%).

${ }^{1} \mathbf{H}$ NMR $\left(400 \mathrm{MHz}, \mathrm{CDCl}_{3}\right) \delta 8.60(\mathrm{~s}, 1 \mathrm{H}), 8.43-8.37(\mathrm{~m}, 1 \mathrm{H}), 7.99-7.91(\mathrm{~m}, 2 \mathrm{H}), 7.64-$ $7.56(\mathrm{~m}, 1 \mathrm{H}), 7.56-7.49(\mathrm{~m}, 2 \mathrm{H}), 7.29$ (d, J = 7.8 Hz, 1H), 7.05 (ddd, J = 7.5, 1.7, $0.8 \mathrm{~Hz}, 1 \mathrm{H})$, $2.46(\mathrm{~s}, 3 \mathrm{H}) \mathrm{ppm}$.

${ }^{13}$ C NMR $(151 \mathrm{MHz}, \mathrm{CDCl} 3) \delta 165.5,138.7,136.1,135.0,132.3,129.1,127.9,127.3,126.4$, $119.3,116.7,24.0 \mathrm{ppm}$.

LRMS (APCI) m/z: $[\mathrm{M}+\mathrm{H}]^{+}$calc'd. for $\mathrm{C}_{14} \mathrm{H}_{13} \mathrm{BrNO}, 290.0$; found 289.7 
<smiles>O=C(c1ccccc1)N(c1cccc([N+](=O)[O-])c1Br)[N+](=O)[O-]</smiles>

$N$-(2-bromo-3-methylphenyl)- $N$-methylbenzamide (S11): In a vial under nitrogen, sodium hydride as a $60 \%$ dispersion in mineral oil (120 mg, $3.0 \mathrm{mmol}, 1.5$ equiv) was suspended in DMF (15 mL) and cooled to $0{ }^{\circ} \mathrm{C}$. $\mathbf{S 1 0}(580 \mathrm{mg}, 2.0 \mathrm{mmol}, 1.0$ equiv) as a solution in DMF (6 $\mathrm{mL}$ ) was added dropwise to the sodium hydride suspension and stirred for 30 minutes before the addition of methyl iodide $(0.15 \mathrm{~mL}, 2.4 \mathrm{mmol}, 1.2$ equiv). The reaction was removed from the ice bath, and after reacting for $1.5 \mathrm{~h}$ was quenched water. The resulting mixture was diluted with ethyl acetate and washed with brine 3x. The organic layer was dried with $\mathrm{MgSO}_{4}$ and concentrated in vacuo to afford the title compound as a light pink solid (573 $\mathrm{mg}, 94 \%)$. ${ }^{1} \mathbf{H}$ NMR $\left(400 \mathrm{MHz}, \mathrm{CDCl}_{3}\right) \delta 7.35(\mathrm{dt}, \mathrm{J}=7.0,1.4 \mathrm{~Hz}, 2 \mathrm{H}), 7.26-7.17(\mathrm{~m}, 1 \mathrm{H}), 7.14(\mathrm{tt}, \mathrm{J}=$ 6.7, 1.7 Hz, 2H), $7.09-7.01(\mathrm{~m}, 2 \mathrm{H}), 6.91(\mathrm{dd}, \mathrm{J}=7.5,2.1 \mathrm{~Hz}, 1 \mathrm{H}), 3.38(\mathrm{~s}, 3 \mathrm{H}), 2.39(\mathrm{~s}, 3 \mathrm{H})$ ppm.

${ }^{13} \mathrm{C}$ NMR $\left(151 \mathrm{MHz}, \mathrm{CDCl}_{3}\right) \delta 171.2,144.1,140.4,136.1,129.9,129.8,128.2,127.8,127.7$, $125.5,37.3,23.9 \mathrm{ppm}$.

LRMS (APCI) m/z: [M+H] $]^{+}$calc'd. for $\mathrm{C}_{15} \mathrm{H}_{15} \mathrm{BrNO}, 304.0$; found 303.7<smiles>Cc1ccc(Br)c(NC(=O)c2ccccc2)c1</smiles>

$\mathbf{N}$-(2-bromo-5-methylphenyl)benzamide (S12): To a solution of 2-bromo-5-methylaniline (614 $\mathrm{mg}, 3.3 \mathrm{mmol}, 1.1$ equiv) in DCM $(30 \mathrm{~mL})$ was added benzoyl chloride $(0.35 \mathrm{~mL}, 3.0 \mathrm{mmol}, 1.0$ equiv) dropwise via syringe, followed by triethylamine $(0.46 \mathrm{~mL}, 3.3 \mathrm{mmol}, 1.1$ equiv $)$. The resulting mixture was stirred at room temperature for $16 \mathrm{~h}$, quenched with sat. aq. $\mathrm{NH}_{4} \mathrm{Cl}$, and extracted with DCM 3x. The combined organic layers were washed with $1 \mathrm{M} \mathrm{HCl} \mathrm{(aq)} \mathrm{and} \mathrm{brine,}$ dried over MgSO4, and concentrated in vacuo to afford the title compound as an off-white solid (839 mg, 96\%).

${ }^{1}$ H NMR $\left(400 \mathrm{MHz}, \mathrm{CDCl}_{3}\right) \delta 8.46-8.37(\mathrm{~m}, 2 \mathrm{H}), 7.92(\mathrm{~d}, \mathrm{~J}=7.0 \mathrm{~Hz}, 1 \mathrm{H}), 7.57(\mathrm{t}, \mathrm{J}=7.3 \mathrm{~Hz}$, $1 \mathrm{H}), 7.51(\mathrm{t}, \mathrm{J}=7.3 \mathrm{~Hz}, 2 \mathrm{H}), 7.43(\mathrm{~d}, \mathrm{~J}=8.2 \mathrm{~Hz}, 1 \mathrm{H}), 6.83(\mathrm{dd}, \mathrm{J}=8.2,2.1 \mathrm{~Hz}, 1 \mathrm{H}), 2.35(\mathrm{~s}, 3 \mathrm{H})$ ppm.

${ }^{1} \mathrm{H}$ NMR spectrum is consistent with reported values ${ }^{7}$<smiles>Cc1ccc(Br)c(N(C(=O)[O-])C(=O)c2ccccc2)c1</smiles>

$\boldsymbol{N}$-(2-bromo-5-methylphenyl)- $\boldsymbol{N}$-methylbenzamide (S13): In a vial under nitrogen, sodium hydride as a $60 \%$ dispersion in mineral oil (120 mg, $3.0 \mathrm{mmol}, 1.5$ equiv) was suspended in DMF (20 mL) and cooled to $0{ }^{\circ} \mathrm{C} . \mathbf{S 1 2}$ as a solution in DMF (580 mg, $2.0 \mathrm{mmol}, 1.0$ equiv in about $6 \mathrm{~mL}$ DMF) was added dropwise to the sodium hydride suspension and stirred for 30 minutes before the addition of methyl iodide $(0.15 \mathrm{~mL}, 2.4 \mathrm{mmol}, 1.2$ equiv). The reaction was removed from the ice bath, and after reacting for $1 \mathrm{~h}$ was quenched with water and extracted with EtOAc 3x. The combined organic layers were washed with water and brine, dried with $\mathrm{MgSO}_{4}$, and concentrated in vacuo to afford the title compound as a light yellow solid (577 mg, 95\%). 
${ }^{1} \mathbf{H}$ NMR $\left(400 \mathrm{MHz}, \mathrm{CDCl}_{3}\right) \delta 7.41-7.32(\mathrm{~m}, 4 \mathrm{H}), 7.27-7.18(\mathrm{~m}, 1 \mathrm{H}), 7.15(\mathrm{t}, \mathrm{J}=7.5 \mathrm{~Hz}, 2 \mathrm{H})$, $6.92-6.83(\mathrm{~m}, 2 \mathrm{H}), 3.37(\mathrm{~s}, 3 \mathrm{H}), 2.17(\mathrm{~s}, 3 \mathrm{H}) \mathrm{ppm}$.

${ }^{13} \mathbf{C}$ NMR $\left(126 \mathrm{MHz}, \mathrm{CDCl}_{3}\right) \delta 171.0,143.5,138.8,135.9,133.4,131.3,130.0,129.8,128.2$, 127.7, 119.3, 37.2, $20.8 \mathrm{ppm}$.

LRMS (APCI) m/z: $[\mathrm{M}+\mathrm{H}]^{+}$calc'd. for $\mathrm{C}_{15} \mathrm{H}_{15} \mathrm{BrNO}, 304.0$; found 303.7<smiles>CC(=O)c1ccc(I)c(OCc2ccccc2)c1</smiles>

Methyl 3-(benzyloxy)-4-iodobenzoate (S14): A round bottom flask was charged with methyl 3hydroxy-4-iodobenzoate (417 mg, $1.5 \mathrm{mmol}, 1.0$ equiv) and $\mathrm{K}_{2} \mathrm{CO}_{3}(415 \mathrm{mg}, 1.5 \mathrm{mmol}, 1.0$ equiv). MeCN (10 mL) was added, followed by benzyl bromide (0.18 mL, $3.0 \mathrm{mmol}, 2.0$ equiv). The reaction was heated to $60^{\circ} \mathrm{C}$ and stirred for $18 \mathrm{~h}$. The reaction was cooled to room temperature, diluted with water, and extracted with EtOAc 3x. The combined organic layers were washed with brine, dried over $\mathrm{MgSO}_{4}$, and concentrated in vacuo to afford the title compound as a white solid (535 $\mathrm{mg}, 97 \%)$.

${ }^{1} \mathbf{H}$ NMR $\left(500 \mathrm{MHz}, \mathrm{CDCl}_{3}\right) \delta 7.88(\mathrm{~d}, \mathrm{~J}=8.1 \mathrm{~Hz}, 1 \mathrm{H}), 7.56-7.50(\mathrm{~m}, 3 \mathrm{H}), 7.44-7.37$ (m, $3 \mathrm{H}), 7.34(\mathrm{t}, \mathrm{J}=7.3 \mathrm{~Hz}, 1 \mathrm{H}), 5.21(\mathrm{~s}, 2 \mathrm{H}), 3.91(\mathrm{~s}, 3 \mathrm{H}) \mathrm{ppm}$.

${ }^{1} \mathrm{H}$ NMR spectra are consistent with reported values ${ }^{8}$<smiles>N#Cc1ccc(OCc2ccccc2)c(Cl)c1</smiles>

4-(benzyloxy)-3-chlorobenzonitrile (S15): A round bottom flask was charged with 3-chloro-4hydroxybenzonitrile (461 mg, $3.0 \mathrm{mmol}, 1.0$ equiv) and $\mathrm{K}_{2} \mathrm{CO}_{3}(829 \mathrm{mg}, 6.0 \mathrm{mmol}, 2.0$ equiv). MeCN (15 mL) was added, followed by benzyl bromide $(0.36 \mathrm{~mL}, 3.0 \mathrm{mmol}, 1.0$ equiv). The reaction was heated to $60{ }^{\circ} \mathrm{C}$ and stirred for $16 \mathrm{~h}$. The reaction was cooled to room temperature, diluted with water, and extracted with EtOAc 3x. The combined organic layers were washed with brine, dried over $\mathrm{MgSO}_{4}$, and purified on silica gel (5-10\% EtOAc/hexanes eluent) to afford the title compound as a white solid $(303 \mathrm{mg}, 41 \%)$.

${ }^{1} \mathbf{H}$ NMR $\left(400 \mathrm{MHz}, \mathrm{CDCl}_{3}\right) \delta 7.68(\mathrm{~d}, \mathrm{~J}=2.0 \mathrm{~Hz}, 1 \mathrm{H}), 7.51(\mathrm{ddd}, \mathrm{J}=8.6,2.1,0.3 \mathrm{~Hz}, 1 \mathrm{H}), 7.47$ $-7.31(\mathrm{~m}, 5 \mathrm{H}), 7.01(\mathrm{~d}, \mathrm{~J}=8.6 \mathrm{~Hz}, 1 \mathrm{H}), 5.23(\mathrm{~s}, 2 \mathrm{H}) \mathrm{ppm}$.

${ }^{13} \mathbf{C}$ NMR $\left(151 \mathrm{MHz}, \mathrm{CDCl}_{3}\right) \delta 157.9,135.3,133.9,132.5,129.0,128.7,127.2,124.4,118.1$, $113.9,105.2,71.2 \mathrm{ppm}$.

LRMS (EI) m/z: [M] $]^{+}$calc'd. for $\mathrm{C}_{14} \mathrm{H}_{10} \mathrm{ClNO}$, 243.0; found 243.1<smiles>O=C(Nc1ncccc1Br)c1ccccc1</smiles>

tert-butyl (3-bromopyridin-2-yl)carbamate (S16): To a solution of 2-amino-3-bromopyridine (692 mg, $4.0 \mathrm{mmol}, 1.0$ equiv) in THF (40 mL) was added triethylamine (1.3 mL, $9.6 \mathrm{mmol}, 2.4$ equiv), di-tert-butyl decarbonate (1.92 g, $8.8 \mathrm{mmol}, 2.2$ equiv), and DMAP (49 mg, $0.4 \mathrm{mmol}$, 0.1 equiv). The resulting solution was stirred for $19 \mathrm{~h}$, quenched with sat. aq. $\mathrm{NH}_{4} \mathrm{Cl}$, and extracted with EtOAc 3x. The combined organic layers were dried over $\mathrm{MgSO}_{4}$ and concentrated in vacuo. The resulting solid was dissolved in DCM $(40 \mathrm{~mL})$ and cooled to $0{ }^{\circ} \mathrm{C}$. Trifluoroacetic 
acid was added dropwise, and the resulting solution was stirred for $5.5 \mathrm{~h}$, quenched with sat. aq. $\mathrm{NaHCO}_{3}$, extracted with DCM 3x, dried over $\mathrm{MgSO}_{4}$, and concentrated in vacuo to afford the title compound as a light yellow solid (997 mg, 91\%).

${ }^{1} \mathbf{H}$ NMR $\left(400 \mathrm{MHz}, \mathrm{CDCl}_{3}\right) \delta 8.41(\mathrm{dd}, \mathrm{J}=4.8,1.6 \mathrm{~Hz}, 2 \mathrm{H}), 7.82(\mathrm{dd}, \mathrm{J}=7.9,1.7 \mathrm{~Hz}, 2 \mathrm{H}), 7.30$ (s, 1H), 6.89 (dd, J = 7.9, $4.7 \mathrm{~Hz}, 2 \mathrm{H}), 1.55$ (s, 17H) ppm.

${ }^{13} \mathbf{C}$ NMR $\left(151 \mathrm{MHz}, \mathrm{CDCl}_{3}\right) \delta 150.7,148.8,147.5,141.0,119.8,109.4,81.6,28.3 \mathrm{ppm}$.

LRMS (APCI) m/z: [M+H] calc'd. for $\mathrm{C}_{10} \mathrm{H}_{14} \mathrm{BrN}_{2} \mathrm{O}_{2}, 273.0$; found 272.7<smiles>O=C(c1ccccc1)N(Br)c1ncccc1Br</smiles>

tert-butyl benzyl(3-bromopyridin-2-yl)carbamate (S17): In a round bottom flask under nitrogen, sodium hydride as a $60 \%$ dispersion in mineral oil ( $180 \mathrm{mg}, 4.5 \mathrm{mmol}, 1.5$ equiv) was suspended in DMF (30 mL) and cooled to $0{ }^{\circ} \mathrm{C}$. $\mathbf{S 1 6}$ as a solution in DMF $(819 \mathrm{mg}, 3.0 \mathrm{mmol}$, 1.0 equiv in about $8 \mathrm{~mL}$ DMF) was added dropwise to the sodium hydride suspension and stirred for 30 minutes before the addition of benzyl bromide $(0.43 \mathrm{~mL}, 3.6 \mathrm{mmol}, 1.2$ equiv). The reaction was removed from the ice bath, and after reacting for $1.5 \mathrm{~h}$ was quenched with water and extracted with EtOAc 3x. The combined organic layers were washed with brine, dried over $\mathrm{MgSO}_{4}$, concentrated in vacuo, and purified on silica gel (10-20\% EtOAc/Hex eluent) to afford the title compound as a white solid (830 $\mathrm{mg}, 76 \%)$.

${ }^{1} \mathbf{H}$ NMR $\left(400 \mathrm{MHz}, \mathrm{CDCl}_{3}\right) \delta 8.41(\mathrm{~d}, \mathrm{~J}=3.4 \mathrm{~Hz}, 1 \mathrm{H}), 7.85(\mathrm{~d}, \mathrm{~J}=7.9 \mathrm{~Hz}, 1 \mathrm{H}), 7.32(\mathrm{~s}, 2 \mathrm{H})$, $7.25-7.16(\mathrm{~m}, 3 \mathrm{H}), 7.03(\mathrm{dd}, \mathrm{J}=7.9,4.7 \mathrm{~Hz}, 1 \mathrm{H}), 5.00(\mathrm{~s}, 1 \mathrm{H}), 4.89(\mathrm{~s}, 1 \mathrm{H}), 1.41(\mathrm{~s}, 9 \mathrm{H}) \mathrm{ppm}$. ${ }^{13} \mathrm{C}$ NMR $\left(100 \mathrm{MHz}, \mathrm{CDCl}_{3}, 50{ }^{\circ} \mathrm{C}\right) \delta 153.7,153.6,147.5,142.0,137.9,128.3,127.3,123.2$, $120.8,81.4,52.4,28.4 \mathrm{ppm}$.

LRMS (APCI) m/z: $[\mathrm{M}+\mathrm{H}]^{+}$calc'd. for $\mathrm{C}_{17} \mathrm{H}_{20} \mathrm{BrN}_{2} \mathrm{O}_{2}, 363.1$; found 362.8<smiles>CC(C)(C)Nc1ccncc1Br</smiles>

tert-butyl (3-bromopyridin-4-yl)carbamate (S18): To a solution of 3-bromo-4-pyradinamine (692 mg, $4.0 \mathrm{mmol}, 1.0$ equiv) in THF $(20 \mathrm{~mL})$ was added triethylamine $(1.3 \mathrm{~mL}, 9.6 \mathrm{mmol}, 2.4$ equiv), di-tert-butyl decarbonate ( $1.92 \mathrm{~g}, 8.8 \mathrm{mmol}, 2.2$ equiv), and DMAP (49 mg, $0.4 \mathrm{mmol}$, 0.1 equiv). After stirring for $2.5 \mathrm{~h}, 1 \mathrm{M}$ aq. $\mathrm{HCl}(20 \mathrm{~mL})$ was added, and the resulting solution was stirred for $17 \mathrm{~h}$. The reaction was neutralized with $1 \mathrm{M}$ aq. $\mathrm{NaOH}(20 \mathrm{~mL})$, extracted with EtOAc 3x, dried over $\mathrm{MgSO}_{4}$, concentrated in vacuo, and purified on silica gel $(30 \% \mathrm{EtOAc} / \mathrm{Hex}$ eluent) to afford the title compound as a white solid $(807 \mathrm{mg}, 74 \%)$.

${ }^{1} \mathbf{H}$ NMR $\left(400 \mathrm{MHz}, \mathrm{CDCl}_{3}\right) \delta 8.58(\mathrm{~d}, \mathrm{~J}=0.4 \mathrm{~Hz}, 1 \mathrm{H}), 8.37(\mathrm{dd}, \mathrm{J}=5.7,0.6 \mathrm{~Hz}, 1 \mathrm{H}), 8.15(\mathrm{~d}, \mathrm{~J}$ $=5.7 \mathrm{~Hz}, 1 \mathrm{H}), 7.17(\mathrm{~s}, 1 \mathrm{H}), 1.54(\mathrm{~s}, 9 \mathrm{H}) \mathrm{ppm}$.

${ }^{1} \mathrm{H}$ NMR spectrum is consistent with reported values ${ }^{9}$ 
<smiles>O=C(c1ccccc1)N(Cc1ccccc1)c1ccncc1Br</smiles>

tert-butyl benzyl(3-bromopyridin-4-yl)carbamate (S19): In a round bottom flask under nitrogen, sodium hydride as a $60 \%$ dispersion in mineral oil (120 mg, $3.0 \mathrm{mmol}, 1.5$ equiv) was suspended in DMF (20 mL)and cooled to $0{ }^{\circ} \mathrm{C}$. $\mathbf{S 1 8}(546 \mathrm{mg}, 2.0 \mathrm{mmol}, 1.0$ equiv) as a solution in DMF $(5 \mathrm{~mL})$ was added dropwise to the sodium hydride suspension and stirred for 30 minutes before the addition of benzyl bromide $(0.29 \mathrm{~mL}, 2.4 \mathrm{mmol}, 1.2$ equiv). The reaction was removed from the ice bath, and after reacting for $4 \mathrm{~h}$ was quenched water and extracted with EtOAc 3x. The combined organic layers were washed with water and brine, dried with $\mathrm{MgSO}_{4}$, concentrated in vacuo, and purified on silica gel (10-20\% EtOAc/Hex eluent) to afford the title compound as a yellow oil (488 $\mathrm{mg}, 67 \%)$.

${ }^{1}$ H NMR $\left(500 \mathrm{MHz}, \mathrm{CDCl}_{3}\right) \delta 8.75(\mathrm{~s}, 1 \mathrm{H}), 8.37(\mathrm{~d}, \mathrm{~J}=5.1 \mathrm{~Hz}, 1 \mathrm{H}), 7.30-7.26(\mathrm{~m}, 3 \mathrm{H}), 7.21$ $(\mathrm{dd}, \mathrm{J}=7.5,2.0 \mathrm{~Hz}, 2 \mathrm{H}), 6.86(\mathrm{~s}, 1 \mathrm{H}), 5.12(\mathrm{~s}, 1 \mathrm{H}), 4.43(\mathrm{~s}, 1 \mathrm{H}), 1.42(\mathrm{~s}, 9 \mathrm{H}) \mathrm{ppm}$.

${ }^{13} \mathrm{C} \mathrm{NMR}\left(151 \mathrm{MHz}, \mathrm{CDCl}_{3}, 50{ }^{\circ} \mathrm{C}\right) \delta 153.5,153.4,149.3,148.8,137.2,128.7,127.9,125.3$, $122.0,81.7,65.4,52.7,28.3 \mathrm{ppm}$.

LRMS (APCI) m/z: $[\mathrm{M}+\mathrm{H}]^{+}$calc'd. for $\mathrm{C}_{17} \mathrm{H}_{20} \mathrm{BrN}_{2} \mathrm{O}_{2}, 363.0$; found 362.8<smiles>O=[N+]([O-])c1ccccc1COc1cccnc1Br</smiles>

2-bromo-3-((2-methylbenzyl)oxy)pyridine (S20): A round bottom flask was charged with 2bromo-3-hydroxypyridine (522 mg, $3.0 \mathrm{mmol}, 1.0$ equiv) and $\mathrm{K}_{2} \mathrm{CO}_{3}(829 \mathrm{mg}, 6.0 \mathrm{mmol}, 2.0$ equiv). MeCN (15 mL) was added, followed by 2-methylbenzyl bromide $(0.40 \mathrm{~mL}, 3.0 \mathrm{mmol}$, 1.0 equiv). The reaction was heated to $60^{\circ} \mathrm{C}$ and stirred for $16 \mathrm{~h}$. The reaction was cooled to room temperature, diluted with water, and extracted with EtOAc 3x. The combined organic layers were washed with brine, dried over $\mathrm{MgSO}_{4}$, and purified on silica gel $(20 \%$ EtOAc/hexanes eluent) to afford the title compound as a white solid (677 $\mathrm{mg}, 81 \%)$.

${ }^{1} \mathbf{H}$ NMR $\left(400 \mathrm{MHz} \mathrm{CDCl}_{3}\right) \delta 8.00(\mathrm{t}, \mathrm{J}=3.1 \mathrm{~Hz}, 1 \mathrm{H}), 7.47-7.41(\mathrm{~m}, 1 \mathrm{H}), 7.32-7.22(\mathrm{~m}, 4 \mathrm{H})$, $7.20(\mathrm{~d}, \mathrm{~J}=3.1 \mathrm{~Hz}, 1 \mathrm{H}), 5.14(\mathrm{~s}, 2 \mathrm{H}), 2.41(\mathrm{~s}, 3 \mathrm{H}) \mathrm{ppm}$.

${ }^{13} \mathrm{C}$ NMR $\left(151 \mathrm{MHz}, \mathrm{CDCl}_{3}\right) \delta 152.3,141.7,136.7,133.6,133.5,130.7,128.8,128.5,126.3$, 123.5, 120.4, 69.8, $19.2 \mathrm{ppm}$.

LRMS (APCI) m/z: $[\mathrm{M}+\mathrm{H}]^{+}$calc'd. for $\mathrm{C}_{13} \mathrm{H}_{13} \mathrm{BrNO}, 278.0$; found 277.8<smiles>Cc1cccc(COc2cccnc2Br)c1</smiles>

2-bromo-3-((3-methylbenzyl)oxy)pyridine (S21): A round bottom flask was charged with 2bromo-3-hydroxypyridine (522 mg, $3.0 \mathrm{mmol}, 1.0$ equiv) and $\mathrm{K}_{2} \mathrm{CO}_{3}(829 \mathrm{mg}, 6.0 \mathrm{mmol}, 2.0$ equiv). MeCN (15 mL) was added, followed by 1-(bromomethyl)-3-methylbenzene $(0.41 \mathrm{~mL}$, $3.0 \mathrm{mmol}, 1.0$ equiv). The reaction was heated to $60^{\circ} \mathrm{C}$ and stirred for $15.5 \mathrm{~h}$. The reaction was cooled to room temperature, diluted with water, and extracted with EtOAc 3x. The combined organic layers were washed with brine, dried over $\mathrm{MgSO}_{4}$, and concentrated in vacuo to afford the title compound as a light brown solid (826 mg, 99\%). 
${ }^{1} \mathbf{H}$ NMR $\left(400 \mathrm{MHz}, \mathrm{CDCl}_{3}\right) \delta 7.99(\mathrm{dd}, \mathrm{J}=4.1,2.1 \mathrm{~Hz}, 1 \mathrm{H}), 7.32-7.22(\mathrm{~m}, 3 \mathrm{H}), 7.19-7.11$ (m, 3H), 5.15 (s, 2H), 2.38 (s, 3H) ppm.

${ }^{13}$ C NMR $\left(151 \mathrm{MHz}, \mathrm{CDCl}_{3}\right) \delta 152.3,141.7,138.7,135.6,133.6,129.3,128.8,127.9,124.3$, $123.5,120.7,71.2,21.6 \mathrm{ppm}$.

LRMS (APCI) m/z: $[\mathrm{M}+\mathrm{H}]^{+}$calc'd. for $\mathrm{C}_{13} \mathrm{H}_{13} \mathrm{BrNO}, 278.0$; found 277.8<smiles>COc1cccc(COc2cccnc2Br)c1</smiles>

2-bromo-3-((3-methoxybenzyl)oxy)pyridine (S22): A round bottom flask was charged with 2bromo-3-hydroxypyridine (522 mg, $3.0 \mathrm{mmol}, 1.0$ equiv) and $\mathrm{K}_{2} \mathrm{CO}_{3}(829 \mathrm{mg}, 6.0 \mathrm{mmol}, 2.0$ equiv). MeCN (15 mL) was added, followed by 3-methoxybenzyl bromide $(0.42 \mathrm{~mL}, 3.0 \mathrm{mmol}$, 1.0 equiv). The reaction was heated to $60^{\circ} \mathrm{C}$ and stirred for $15 \mathrm{~h}$. The reaction was cooled to room temperature, diluted with water, and extracted with EtOAc 3x. The combined organic layers were washed with brine, dried over $\mathrm{MgSO}_{4}$, and concentrated in vacuo to afford the title compound as a white solid (733 $\mathrm{mg}, 83 \%)$.

${ }^{1} \mathbf{H}$ NMR $\left(600 \mathrm{MHz}, \mathrm{CDCl}_{3}\right) \delta 7.99(\mathrm{dd}, J=4.2,2.0 \mathrm{~Hz}, 1 \mathrm{H}), 7.36-7.29(\mathrm{~m}, 1 \mathrm{H}), 7.21-7.14$ (m, 2H), $7.07-6.98$ (m, 2H), 6.88 (ddd, $J=8.3,2.6,0.9 \mathrm{~Hz}, 1 \mathrm{H}), 5.17$ (s, 2H), 3.83 (s, 3H).

${ }^{13}$ C NMR $\left(151 \mathrm{MHz}, \mathrm{CDCl}_{3}\right) \delta 156.0,152.0,141.6,137.1,133.3,129.8,123.4,120.5,119.1$, 113.8, 112.4, 70.7, 55.3.

LRMS (APCI) m/z: [M+H] $]^{+}$calc'd. for $\mathrm{C}_{13} \mathrm{H}_{13} \mathrm{BrNO}_{2}$, 294.0; found 293.8 .

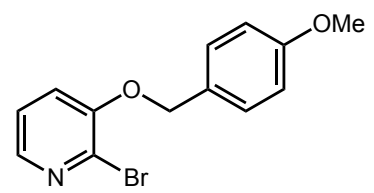

2-bromo-3-((4-methoxybenzyl)oxy)pyridine (S23): A round bottom flask was charged with 2bromo-3-hydroxypyridine (522 mg, $3.0 \mathrm{mmol}, 1.0$ equiv) and $\mathrm{K}_{2} \mathrm{CO}_{3}(829 \mathrm{mg}, 6.0 \mathrm{mmol}, 2.0$ equiv). $\mathrm{MeCN}(15 \mathrm{~mL})$ was added, followed by 4-methoxybenzyl bromide $(0.49 \mathrm{~mL}, 3.6 \mathrm{mmol}$, 1.2 equiv). The reaction was heated to $60^{\circ} \mathrm{C}$ and stirred for $22 \mathrm{~h}$. The reaction was cooled to room temperature, diluted with water, and extracted with EtOAc 3x. The combined organic layers were washed with brine, dried over $\mathrm{MgSO}_{4}$, and purified on silica gel (10-40\% EtOAc/hexanes eluent) to afford the title compound as a white solid (699 mg, 79\%).

${ }^{1} \mathbf{H}$ NMR $\left(400 \mathrm{MHz}, \mathrm{CDCl}_{3}\right) \delta 7.99(\mathrm{dd}, \mathrm{J}=3.7,2.5 \mathrm{~Hz}, 1 \mathrm{H}), 7.38(\mathrm{dt}, \mathrm{J}=8.8,0.6 \mathrm{~Hz}, 2 \mathrm{H}), 7.19$ $-7.14(\mathrm{~m}, 2 \mathrm{H}), 6.93(\mathrm{~d}, \mathrm{~J}=8.7 \mathrm{~Hz}, 2 \mathrm{H}), 5.11(\mathrm{~s}, 2 \mathrm{H}), 3.82(\mathrm{~s}, 3 \mathrm{H}) \mathrm{ppm}$.

${ }^{13}$ C NMR $\left(151 \mathrm{MHz}, \mathrm{CDCl}_{3}\right) \delta 159.9,152.3,141.7,133.7,129.0,127.7,123.5,120.8,114.3$, 71.1, $55.5 \mathrm{ppm}$.

LRMS (APCI) m/z: $[\mathrm{M}+\mathrm{H}]^{+}$calc'd. for $\mathrm{C}_{13} \mathrm{H}_{13} \mathrm{BrNO}_{2}, 294.0$; found 293.8<smiles>COc1cc(F)cc(C(=O)Nc2ccccc2I)c1</smiles>

3-fluoro- $\mathrm{N}$-(2-iodophenyl)-5-methoxybenzamide (S24): To a solution of 3-fluoro-5methoxybenzoic acid $(510 \mathrm{mg}, 3.0 \mathrm{mmol}, 1.0$ equiv) in DMF $(12 \mathrm{~mL})$ was added HBTU $(1.25 \mathrm{~g}$, 
$3.3 \mathrm{mmol}, 1.1$ equiv), 2-iodoaniline ( $723 \mathrm{mg}, 3.3 \mathrm{mmol}, 1.1$ equiv), and diisopropylethylamine $\left(1.04 \mathrm{~mL}, 6.0 \mathrm{mmol}, 2.0\right.$ equiv). After heating at $80^{\circ} \mathrm{C}$ for $16.5 \mathrm{~h}$, the reaction was quenched with sat. aq. $\mathrm{NH}_{4} \mathrm{Cl}$ and extracted with EtOAc $3 \mathrm{x}$. The combined organic layers were washed with water, $1 \mathrm{M}$ aq $\mathrm{HCl}$, and brine, dried over $\mathrm{MgSO}_{4}$, and purified on silica gel $(5 \%$ EtOAc/hexanes eluent) to afford the title compound as a light yellow solid (334 mg, 30\%). ${ }^{1} \mathbf{H}$ NMR $\left(400 \mathrm{MHz}, \mathrm{CDCl}_{3}\right) \delta 8.42(\mathrm{dd}, \mathrm{J}=8.3,1.6 \mathrm{~Hz}, 1 \mathrm{H}), 8.20(\mathrm{~s}, 1 \mathrm{H}), 7.83(\mathrm{dd}, \mathrm{J}=8.0,1.4$ $\mathrm{Hz}, 1 \mathrm{H}), 7.46-7.37(\mathrm{~m}, 1 \mathrm{H}), 7.30(\mathrm{t}, \mathrm{J}=1.9 \mathrm{~Hz}, 1 \mathrm{H}), 7.23(\mathrm{dt}, \mathrm{J}=8.6,1.9 \mathrm{~Hz}, 1 \mathrm{H}), 6.91(\mathrm{td}, \mathrm{J}=$ 7.7, $1.6 \mathrm{~Hz}, 1 \mathrm{H}), 6.83(\mathrm{dt}, \mathrm{J}=10.2,2.3 \mathrm{~Hz}, 1 \mathrm{H}), 3.89(\mathrm{~s}, 3 \mathrm{H}) \mathrm{ppm}$.

${ }^{13} \mathbf{C ~ N M R}\left(125 \mathrm{MHz}, \mathrm{CDCl}_{3}\right) \delta 164.2\left(\mathrm{~d},{ }^{4} \mathrm{~J}_{\mathrm{C}-\mathrm{F}}=3.2 \mathrm{~Hz}\right), 163.7\left(\mathrm{~d},{ }^{1} \mathrm{~J}_{\mathrm{C}-\mathrm{F}}=247.5 \mathrm{~Hz}\right), 161.5(\mathrm{~d}$, $\left.{ }^{3} \mathrm{~J}_{\mathrm{C}-\mathrm{F}}=11.1 \mathrm{~Hz}\right), 139.0,138.1,137.4\left(\mathrm{~d},{ }^{3} \mathrm{~J}_{\mathrm{C}-\mathrm{F}}=8.6 \mathrm{~Hz}\right), 129.6,126.5,122.0,109.0\left(\mathrm{~d},{ }^{4} \mathrm{~J}_{\mathrm{C}-\mathrm{F}}=2.6\right.$ $\mathrm{Hz}), 106.6\left(\mathrm{~d},{ }^{2} \mathrm{~J}_{\mathrm{C}-\mathrm{F}}=23.5 \mathrm{~Hz}\right), 105.6\left(\mathrm{~d},{ }^{2} \mathrm{~J}_{\mathrm{C}-\mathrm{F}}=25.1 \mathrm{~Hz}\right), 90.5,56.0 \mathrm{ppm}$.

${ }^{19}$ F NMR $\left(376 \mathrm{MHz}, \mathrm{CDCl}_{3}\right) \delta-109.6(\mathrm{dd}, \mathrm{J}=10.0,8.5 \mathrm{~Hz}) \mathrm{ppm}$.

LRMS (APCI) m/z: $[\mathrm{M}+\mathrm{H}]^{+}$calc'd. for $\mathrm{C}_{14} \mathrm{H}_{12} \mathrm{FINO}_{2}, 372.0$; found 371.6<smiles>COc1cc(F)cc(C(=O)N(C)c2ccccc2Cl)c1</smiles>

3-fluoro- $N$-(2-iodophenyl)-5-methoxy- $N$-methylbenzamide (S25): In a vial under nitrogen, sodium hydride as a $60 \%$ dispersion in mineral oil ( $48 \mathrm{mg}, 1.2 \mathrm{mmol}, 1.5$ equiv) was suspended in DMF $(10 \mathrm{~mL})$ and cooled to $0{ }^{\circ} \mathrm{C}$. $\mathbf{S 2 4}(297 \mathrm{mg}, 0.80 \mathrm{mmol}, 1.0$ equiv) as a solution in DMF $(3 \mathrm{~mL})$ was added dropwise to the sodium hydride suspension and stirred for 30 minutes before the addition of methyl iodide ( $60 \mu \mathrm{L}, 0.96 \mathrm{mmol}, 1.5$ equiv). The reaction was removed from the ice bath, and after reacting for $1 \mathrm{~h}$ was quenched with water and extracted with EtOAc 3x. The combined organic layers were washed with water and brine, dried with $\mathrm{MgSO}_{4}$, and concentrated in vacuo to afford the title compound as a yellow solid (287 $\mathrm{mg}, 93 \%)$.

${ }^{1} \mathbf{H}$ NMR $\left(400 \mathrm{MHz}, \mathrm{CDCl}_{3}\right) \delta 7.83(\mathrm{dd}, \mathrm{J}=7.9,1.4 \mathrm{~Hz}, 1 \mathrm{H}), 7.25-7.21(\mathrm{~m}, 1 \mathrm{H}), 7.09(\mathrm{dd}, \mathrm{J}=$ $7.9,1.6 \mathrm{~Hz}, 1 \mathrm{H}), 6.94(\mathrm{td}, \mathrm{J}=7.8,1.6 \mathrm{~Hz}, 1 \mathrm{H}), 6.73-6.65(\mathrm{~m}, 2 \mathrm{H}), 6.48(\mathrm{dt}, \mathrm{J}=10.4,2.4 \mathrm{~Hz}$, $1 \mathrm{H}), 3.66(\mathrm{~s}, 3 \mathrm{H}), 3.36(\mathrm{~s}, 3 \mathrm{H}) \mathrm{ppm}$.

${ }^{13}$ C NMR $\left(126 \mathrm{MHz}, \mathrm{CDCl}_{3}\right) \delta 169.2\left(\mathrm{~d},{ }^{4} \mathrm{~J}_{\mathrm{C}-\mathrm{F}}=3.3 \mathrm{~Hz}\right), 162.6\left(\mathrm{~d},{ }^{1} \mathrm{~J}_{\mathrm{C}-\mathrm{F}}=246.0 \mathrm{~Hz}\right), 160.1(\mathrm{~d}$, $\left.{ }^{3} \mathrm{~J}_{\mathrm{C}-\mathrm{F}}=10.9 \mathrm{~Hz}\right), 146.6,140.2,138.0\left(\mathrm{~d},{ }^{3} \mathrm{~J}_{\mathrm{C}-\mathrm{F}}=8.3 \mathrm{~Hz}\right), 130.0,129.5,129.4,109.2,107.9\left(\mathrm{~d},{ }^{2} \mathrm{~J}_{\mathrm{C}-}\right.$ $\mathrm{F}=23.8 \mathrm{~Hz}), 103.8\left(\mathrm{~d},{ }^{4} \mathrm{~J}_{\mathrm{C}-\mathrm{F}}=24.5 \mathrm{~Hz}\right), 98.9,55.6,37.5 \mathrm{ppm}$.

${ }^{19} \mathbf{F}$ NMR $\left(376 \mathrm{MHz}, \mathrm{CDCl}_{3}\right) \delta-111.5(\mathrm{t}, \mathrm{J}=9.6 \mathrm{~Hz}) \mathrm{ppm}$.

LRMS (APCI) $\mathrm{m} / \mathrm{z}$ : $[\mathrm{M}+\mathrm{H}]^{+}$calc'd. for $\mathrm{C}_{15} \mathrm{H}_{14} \mathrm{FINO}_{2}, 386.0$; found 385.6<smiles>O=C(Nc1ccccc1I)c1cccc2ncccc12</smiles>

$\mathrm{N}$-(2-iodophenyl)quinoline-5-carboxamide (S26): To a solution of quinoline-5-carboxylic acid (520 mg, 3.0 mmol, 1.0 equiv) in DMF (12 mL) was added HBTU (1.25 g, $3.3 \mathrm{mmol}, 1.1$ equiv), 2-iodoaniline (723 mg, $3.3 \mathrm{mmol}, 1.1$ equiv), and diisopropylethylamine (1.04 mL, $6.0 \mathrm{mmol}$, 2.0 equiv). After heating at $80^{\circ} \mathrm{C}$ for $20.5 \mathrm{~h}$, the reaction was quenched with sat. aq. $\mathrm{NH}_{4} \mathrm{Cl}$ and extracted with EtOAc 3x. The combined organic layers were washed with water, $1 \mathrm{M} \mathrm{aq} \mathrm{HCl}$, and brine, dried over $\mathrm{MgSO}_{4}$, and purified on silica gel (30-50\% EtOAc/hexanes eluent) to afford the title compound as an off-white solid (385 mg, 34\%). 
${ }^{1} \mathbf{H}$ NMR $\left(500 \mathrm{MHz}, \mathrm{CDCl}_{3}\right) \delta 9.01(\mathrm{dd}, \mathrm{J}=4.3,1.6 \mathrm{~Hz}, 1 \mathrm{H}), 8.95(\mathrm{~d}, \mathrm{~J}=8.7 \mathrm{~Hz}, 1 \mathrm{H}), 8.48(\mathrm{~d}, \mathrm{~J}$ $=7.9 \mathrm{~Hz}, 1 \mathrm{H}), 8.33(\mathrm{~d}, \mathrm{~J}=8.5 \mathrm{~Hz}, 1 \mathrm{H}), 8.12(\mathrm{~s}, 1 \mathrm{H}), 8.00(\mathrm{~d}, \mathrm{~J}=7.2 \mathrm{~Hz}, 1 \mathrm{H}), 7.86(\mathrm{dd}, \mathrm{J}=8.0$, $1.4 \mathrm{~Hz}, 1 \mathrm{H}), 7.82(\mathrm{t}, \mathrm{J}=7.8 \mathrm{~Hz}, 1 \mathrm{H}), 7.55(\mathrm{dd}, \mathrm{J}=8.7,4.2 \mathrm{~Hz}, 1 \mathrm{H}), 7.46(\mathrm{dd}, \mathrm{J}=8.5,7.1 \mathrm{~Hz}$, $1 \mathrm{H}), 6.97-6.92(\mathrm{~m}, 1 \mathrm{H}) \mathrm{ppm}$.

${ }^{13}$ C NMR $\left(151 \mathrm{MHz}, \mathrm{CDCl}_{3}\right) \delta 166.3,151.3,148.5,139.2,138.4,134.5,134.0,133.3,129.7$, $128.6,126.8,126.2,125.9,122.5,122.4,90.7 \mathrm{ppm}$.

LRMS (APCI) m/z: $[\mathrm{M}+\mathrm{H}]^{+}$calc'd. for $\mathrm{C}_{16} \mathrm{H}_{12} \mathrm{IN}_{2} \mathrm{O}, 375.0$; found 374.6<smiles>CN(C(=O)c1cccc2ncccc12)c1ccccc1I</smiles>

$N$-(2-iodophenyl)- $N$-methylquinoline-5-carboxamide (S27): In a vial under nitrogen, sodium hydride as a $60 \%$ dispersion in mineral oil ( $48 \mathrm{mg}, 1.2 \mathrm{mmol}, 1.5$ equiv) was suspended in DMF $\left(5 \mathrm{~mL}\right.$ ) and cooled to $0{ }^{\circ} \mathrm{C}$. S26 (299 $\mathrm{mg}, 0.80 \mathrm{mmol}, 1.0$ equiv) as a solution in DMF (3 mL) was added dropwise to the sodium hydride suspension and stirred for 30 minutes before the addition of methyl iodide ( $60 \mu \mathrm{L}, 0.96 \mathrm{mmol}, 1.5$ equiv). The reaction was removed from the ice bath, and after reacting for $1 \mathrm{~h}$ was quenched with water and extracted with EtOAc 3x. The combined organic layers were washed with water and brine, dried over $\mathrm{MgSO}_{4}$, and purified on silica gel (30-50\% EtOAc/hexanes eluent) to afford the title compound as a white solid (218 $\mathrm{mg}$, $70 \%$ ). Appeared as rotameric mixtures in ${ }^{1} \mathrm{H}$ NMR; no coalescence of peaks in $\mathrm{CDCl}_{3}$ up to 60 ${ }^{\circ} \mathrm{C}$; major observed reported.

${ }^{1} \mathbf{H}$ NMR $\left(400 \mathrm{MHz}, \mathrm{CDCl}_{3}\right) \delta 8.92(\mathrm{dd}, \mathrm{J}=4.2,1.7 \mathrm{~Hz}, 1 \mathrm{H}), 8.66-8.60(\mathrm{~m}, 1 \mathrm{H}), 7.95(\mathrm{dt}, \mathrm{J}=$ $8.2,1.2 \mathrm{~Hz}, 1 \mathrm{H}), 7.74(\mathrm{dd}, \mathrm{J}=7.9,1.4 \mathrm{~Hz}, 1 \mathrm{H}), 7.53-7.37(\mathrm{~m}, 3 \mathrm{H}), 7.04-6.92(\mathrm{~m}, 2 \mathrm{H}), 6.80$ (ddd, J = 7.9, 7.2, $1.8 \mathrm{~Hz}, 1 \mathrm{H}), 3.52(\mathrm{~s}, 3 \mathrm{H}) \mathrm{ppm}$.

${ }^{13}$ C NMR $\left(126 \mathrm{MHz}, \mathrm{CDCl}_{3}\right) \delta 169.3,150.7,148.1,146.3,140.4,134.5,133.8,131.1,129.5$, $129.4,129.4,128.0,126.0,125.6,121.7,98.8,37.2 \mathrm{ppm}$.

LRMS (APCI) m/z: $[\mathrm{M}+\mathrm{H}]^{+}$calc'd. for $\mathrm{C}_{17} \mathrm{H}_{14} \mathrm{IN}_{2} \mathrm{O}, 389.0$; found 388.6<smiles>O=C(Nc1ccccc1I)c1ccccc1Cl</smiles>

2-chloro- $\boldsymbol{N}$-(2-iodophenyl)benzamide (S28): To a solution of 2-iodoaniline (604 $\mathrm{mg}, 2.8 \mathrm{mmol}$, 1.0 equiv) in DCM (30 mL) was added 2-chlorobenzoyl chloride (390 $\mu \mathrm{L}, 3.0 \mathrm{mmol}, 1.1$ equiv) dropwise via syringe, followed by triethylamine $(450 \mu \mathrm{L}, 3.2 \mathrm{mmol}, 1.1$ equiv). The resulting mixture was stirred at room temperature for $4 \mathrm{~h}$, quenched with methanol, and concentrated. The resulting solid was purified on silica gel (10-20\% eluent) to afford the title compound as a white solid. (695 mg, $71 \%$ ).

${ }^{1}$ H NMR $\left(399 \mathrm{MHz}, \mathrm{CDCl}_{3}\right) \delta 8.39(\mathrm{~d}, J=8.3 \mathrm{~Hz}, 1 \mathrm{H}), 8.16(\mathrm{~s}, 1 \mathrm{H}), 7.81(\mathrm{dd}, J=8.0,1.5 \mathrm{~Hz}$, $1 \mathrm{H}), 7.76(\mathrm{dd}, J=7.5,2.0 \mathrm{~Hz}, 1 \mathrm{H}), 7.55-7.31(\mathrm{~m}, 4 \mathrm{H}), 6.89(\mathrm{td}, J=7.7,1.6 \mathrm{~Hz}, 1 \mathrm{H})$.

${ }^{13}$ C NMR $\left(100 \mathrm{MHz}, \mathrm{CDCl}_{3}\right) \delta 164.6,139.1,138.2,134.9,131.9,130.9,130.6,130.2,129.3$, 127.3, 126.5, 122.4, 90.1.

LRMS (APCI) m/z: $[\mathrm{M}+\mathrm{H}]^{+}$calc'd. for $\mathrm{C}_{13} \mathrm{H}_{10} \mathrm{ClINO}, 357.9$; found 357.6 
<smiles>CN(C(=O)c1ccccc1Cl)c1ccccc1I</smiles>

2-chloro- $\boldsymbol{N}$-(2-iodophenyl)- $\boldsymbol{N}$-methylbenzamide (S29): In a vial under nitrogen, sodium hydride as a $60 \%$ dispersion in mineral oil ( $90 \mathrm{mg}, 2.2 \mathrm{mmol}, 1.8$ equiv) was suspended in DMF $(15 \mathrm{~mL})$ and cooled to $0{ }^{\circ} \mathrm{C}$. $\mathbf{S 2 8}$ as a solution in DMF (441 mg, $1.2 \mathrm{mmol}, 1.0$ equiv in about 4 $\mathrm{mL}$ DMF) was added to the sodium hydride suspension dropwise and stirred for 30 minutes before the addition of methyl iodide $(120 \mu \mathrm{L}, 1.8 \mathrm{mmol}, 1.5$ equiv). The reaction was removed from the ice bath, and after reacting for $1.5 \mathrm{~h}$ was quenched with methanol then water at $0{ }^{\circ} \mathrm{C}$. The resulting mixture was diluted with ethyl acetate and washed with brine 3x. The organic layer was dried with $\mathrm{MgSO}_{4}$, concentrated in vacuo, and purified on silica gel (10-25\% EtOAc/Hex eluent) to afford the title compound as a white solid (384 mg, 84\%). Appeared as rotameric mixtures in ${ }^{1} \mathrm{H}$ NMR; no coalescence of peaks in $\mathrm{CDCl}_{3}$ up to $60{ }^{\circ} \mathrm{C}$; major observed reported. ${ }^{1} \mathbf{H}$ NMR $\left(400 \mathrm{MHz}, \mathrm{CDCl}_{3}\right) \delta 7.75(\mathrm{dd}, J=7.9,1.4 \mathrm{~Hz}, 1 \mathrm{H}), 7.40(\mathrm{dd}, J=7.6,1.8 \mathrm{~Hz}, 1 \mathrm{H}), 7.35$ $(\mathrm{dd}, J=7.8,1.6 \mathrm{~Hz}, 1 \mathrm{H}), 7.20(\mathrm{dd}, J=8.0,1.3 \mathrm{~Hz}, 1 \mathrm{H}), 7.14(\mathrm{td}, J=7.6,1.4 \mathrm{~Hz}, 1 \mathrm{H}), 7.07$ (td, $J$ $=7.7,1.8 \mathrm{~Hz}, 1 \mathrm{H}), 7.00(\mathrm{td}, J=7.5,1.3 \mathrm{~Hz}, 1 \mathrm{H}), 6.83(\mathrm{td}, J=7.6,1.6 \mathrm{~Hz}, 1 \mathrm{H}), 3.39(\mathrm{~s}, 3 \mathrm{H})$. ${ }^{13} \mathrm{C}$ NMR $\left(100 \mathrm{MHz}, \mathrm{CDCl}_{3}\right) \delta 167.9,145.4,139.9,136.0,130.0,129.6,129.4,129.3,129.0$, 127.9, 127.0, $126.2098 .8,36.4$.

LRMS (APCI) m/z: [M+H] ${ }^{+}$calc'd. for $\mathrm{C}_{14} \mathrm{H}_{12} \mathrm{ClINO}, 371.9$; found 371.6<smiles>O=C(Nc1ccccc1I)c1cccc(Cl)c1</smiles>

3-chloro- $\boldsymbol{N}$-(2-iodophenyl)benzamide (S30): To a solution of 2-iodoaniline (608 $\mathrm{mg}, 2.8 \mathrm{mmol}$, 1.0 equiv) in DCM $(30 \mathrm{~mL})$ was added 3-chlorobenzoyl chloride ( $380 \mu \mathrm{L}, 3.0 \mathrm{mmol}, 1.1$ equiv) dropwise via syringe, followed by triethylamine $(450 \mu \mathrm{L}, 3.2 \mathrm{mmol}, 1.1$ equiv). The resulting mixture was stirred at room temperature for $4 \mathrm{~h}$, quenched with methanol, and concentrated. The resulting solid was purified on silica gel (10-20\% eluent) to afford the title compound as a white solid. (767 mg, $77 \%$ ).

${ }^{1}$ H NMR $\left(399 \mathrm{MHz}, \mathrm{CDCl}_{3}\right) \delta 8.39(\mathrm{dd}, J=8.2,1.6 \mathrm{~Hz}, 1 \mathrm{H}), 8.20(\mathrm{~s}, 1 \mathrm{H}), 8.01-7.90(\mathrm{~m}, 1 \mathrm{H})$, $7.86-7.75(\mathrm{~m}, 2 \mathrm{H}), 7.55(\mathrm{ddd}, J=8.0,2.1,1.1 \mathrm{~Hz}, 1 \mathrm{H}), 7.46(\mathrm{t}, J=7.9 \mathrm{~Hz}, 1 \mathrm{H}), 7.40(\mathrm{~m}, 1 \mathrm{H})$, 6.89 (ddd, $J=8.0,7.3,1.6 \mathrm{~Hz}, 1 \mathrm{H}$ ).

${ }^{13}$ C NMR $\left(100 \mathrm{MHz}, \mathrm{CDCl}_{3}\right) \delta 163.9,138.8,137.9,136.3,135.2,132.2,130.2,129.4,127.7$, 126.4, 125.0, 121.9, 90.4.

LRMS (APCI) m/z: $[\mathrm{M}+\mathrm{H}]^{+}$calc'd. for $\mathrm{C}_{13} \mathrm{H}_{10} \mathrm{ClINO}, 357.9$; found 357.6<smiles>O=C(c1cccc(Cl)c1)N(c1ccccc1I)[N+](=O)[O-]</smiles>

3-chloro- $\boldsymbol{N}$-(2-iodophenyl)- $\boldsymbol{N}$-methylbenzamide (S31): In a vial under nitrogen, sodium hydride as a $60 \%$ dispersion in mineral oil (66 mg, $1.7 \mathrm{mmol}, 1.9$ equiv) was suspended in DMF $(15 \mathrm{~mL})$ and cooled to $0{ }^{\circ} \mathrm{C}$. $\mathbf{S 3 0}$ as a solution in DMF (321 mg, $0.9 \mathrm{mmol}, 1.0$ equiv in about 3 $\mathrm{mL}$ DMF) was added dropwise to the sodium hydride suspension and stirred for 30 minutes before the addition of methyl iodide $(90 \mu \mathrm{L}, 1.4 \mathrm{mmol}, 1.6$ equiv). The reaction was removed from the ice bath, and after reacting for $1.5 \mathrm{~h}$ was quenched with methanol then water at $0{ }^{\circ} \mathrm{C}$. 
The resulting mixture was diluted with ethyl acetate and washed with brine $3 \mathrm{x}$. The organic layer was dried with $\mathrm{MgSO}_{4}$, concentrated in vacuo, and purified on silica gel (10-25\% EtOAc/Hex eluent) to afford the title compound as a white solid (215 mg, 64\%).

${ }^{1} \mathbf{H}$ NMR $\left(399 \mathrm{MHz}, \mathrm{CDCl}_{3}\right) \delta 7.77(\mathrm{dd}, J=7.9,1.4 \mathrm{~Hz}, 1 \mathrm{H}), 7.39(\mathrm{t}, J=1.9 \mathrm{~Hz}, 1 \mathrm{H}), 7.24-$

$7.19(\mathrm{~m}, 1 \mathrm{H}), 7.16(\mathrm{dd}, J=7.9,1.9 \mathrm{~Hz}, 2 \mathrm{H}), 7.09$ (dd, $J=7.9,1.6 \mathrm{~Hz}, 1 \mathrm{H}), 7.03$ (dd, $J=8.4,7.3$ $\mathrm{Hz}, 1 \mathrm{H}), 6.90(\mathrm{td}, J=7.7,1.6 \mathrm{~Hz}, 1 \mathrm{H}), 3.34(\mathrm{~s}, 3 \mathrm{H})$.

${ }^{13}$ C NMR $\left(100 \mathrm{MHz}, \mathrm{CDCl}_{3}\right) \delta 169.2,146.4,140.2,137.3,133.7,130.0,129.9,129.5,129.4$, $128.9,128.6,126.3,98.9,37.5$.

LRMS (APCI) m/z: [M+H] ${ }^{+}$calc'd. for $\mathrm{C}_{14} \mathrm{H}_{12} \mathrm{ClINO}, 372.0$; found 371.6<smiles>Clc1ccc(COc2cccnc2Br)cc1</smiles>

2-bromo-3-((4-chlorobenzyl)oxy)pyridine (S32): A round bottom flask was charged with 2bromo-3-hydroxypyridine (522 mg, $3.0 \mathrm{mmol}, 1.0$ equiv) and $\mathrm{K}_{2} \mathrm{CO}_{3}(829 \mathrm{mg}, 6.0 \mathrm{mmol}, 2.0$ equiv). MeCN (15 mL) was added, followed by 4-chlorobenzyl bromide (740 mg, $3.6 \mathrm{mmol}, 1.2$ equiv). The reaction was heated to $60^{\circ} \mathrm{C}$ and stirred for $20 \mathrm{~h}$. The reaction was cooled to room temperature, diluted with water, and extracted with EtOAc 3x. The combined organic layers were washed with brine, dried over $\mathrm{MgSO}_{4}$, and purified on silica gel (20\% EtOAc/hexanes eluent) to afford the title compound as a white solid (771 $\mathrm{mg}, 86 \%$ ).

${ }^{1} \mathbf{H}$ NMR $\left(500 \mathrm{MHz}, \mathrm{CDCl}_{3}\right) \delta 8.02(\mathrm{dd}, \mathrm{J}=4.6,1.6 \mathrm{~Hz}, 1 \mathrm{H}), 7.44-7.34(\mathrm{~m}, 4 \mathrm{H}), 7.19(\mathrm{dd}, \mathrm{J}=$ $8.1,4.6 \mathrm{~Hz}, 1 \mathrm{H}), 7.14(\mathrm{dd}, \mathrm{J}=8.1,1.6 \mathrm{~Hz}, 1 \mathrm{H}), 5.15$ (s, 2H) ppm.

${ }^{13} \mathbf{C}$ NMR $\left(151 \mathrm{MHz}, \mathrm{CDCl}_{3}\right) \delta 151.9,141.9,134.3,134.1,133.5,129.0,128.5,123.4,120.5$, $70.3 \mathrm{ppm}$.

LRMS (APCI) m/z: [M+H] $]^{+}$calc'd. for $\mathrm{C}_{12} \mathrm{H}_{10} \mathrm{BrClNO}, 298.0$; found 297.7<smiles>Fc1ccccc1COc1cccnc1Br</smiles>

2-bromo-3-((2-fluorobenzyl)oxy)pyridine (S33): A round bottom flask was charged with 2bromo-3-hydroxypyridine (522 mg, $3.0 \mathrm{mmol}, 1.0$ equiv) and $\mathrm{K}_{2} \mathrm{CO}_{3}(829 \mathrm{mg}, 6.0 \mathrm{mmol}, 2.0$ equiv). MeCN (15 mL) was added, followed by 2-fluorobenzyl bromide (0.36 mL, $3.0 \mathrm{mmol}, 1.0$ equiv). The reaction was heated to $60{ }^{\circ} \mathrm{C}$ and stirred for $15 \mathrm{~h}$. The reaction was cooled to room temperature, diluted with water, and extracted with EtOAc 3x. The combined organic layers were washed with brine, dried over $\mathrm{MgSO}_{4}$, and purified on silica gel (10-30\% EtOAc/hexanes eluent) to afford the title compound as a white solid (753 $\mathrm{mg}, 89 \%)$.

${ }^{1} \mathbf{H}$ NMR $\left(400 \mathrm{MHz}, \mathrm{CDCl}_{3}\right) \delta 8.02(\mathrm{dd}, \mathrm{J}=3.8,2.4 \mathrm{~Hz}, 1 \mathrm{H}), 7.60(\mathrm{tdd}, \mathrm{J}=7.5,1.9,0.8 \mathrm{~Hz}, 1 \mathrm{H})$, $7.38-7.30(\mathrm{~m}, 1 \mathrm{H}), 7.24-7.17(\mathrm{~m}, 3 \mathrm{H}), 7.10$ (ddd, J = 10.3, 8.2, $1.1 \mathrm{~Hz}, 1 \mathrm{H}), 5.25(\mathrm{~s}, 3 \mathrm{H}) \mathrm{ppm}$. ${ }^{13} \mathrm{C}$ NMR $\left(151 \mathrm{MHz}, \mathrm{CDCl}_{3}\right) \delta 160.3\left(\mathrm{~d},{ }^{1} \mathrm{~J}_{\mathrm{C}-\mathrm{F}}=246.6 \mathrm{~Hz}\right), 152.0,142.1,133.6,130.2\left(\mathrm{~d},{ }^{3} \mathrm{~J}_{\mathrm{C}-\mathrm{F}}=\right.$ $8.3 \mathrm{~Hz}), 129.5\left(\mathrm{~d},{ }^{3} \mathrm{~J}_{\mathrm{C}-\mathrm{F}}=3.8 \mathrm{~Hz}\right), 124.8\left(\mathrm{~d},{ }^{4} \mathrm{~J}_{\mathrm{C}-\mathrm{F}}=3.7 \mathrm{~Hz}\right), 123.6,123.0\left(\mathrm{~d},{ }^{2} \mathrm{~J}_{\mathrm{C}-\mathrm{F}}=13.9 \mathrm{~Hz}\right)$, $120.5,115.5\left(\mathrm{~d},{ }^{2} \mathrm{~J}_{\mathrm{C}-\mathrm{F}}=21.0 \mathrm{~Hz}\right), 64.8\left(\mathrm{~d},{ }^{3} \mathrm{~J}_{\mathrm{C}-\mathrm{F}}=4.6 \mathrm{~Hz}\right) \mathrm{ppm}$.

${ }^{19}$ F NMR (376 MHz, $\mathrm{CDCl}_{3}$-d) $\delta-117.7--121.1$ (m) ppm.

LRMS (APCI) m/z: $[\mathrm{M}+\mathrm{H}]^{+}$calc'd. for $\mathrm{C}_{12} \mathrm{H}_{10} \mathrm{BrFNO}$, 282.0; found 281.8 
<smiles>Fc1cccc(COc2cccnc2Br)c1</smiles>

2-bromo-3-((3-fluorobenzyl)oxy)pyridine (S34): A round bottom flask was charged with 2bromo-3-hydroxypyridine (522 mg, $3.0 \mathrm{mmol}, 1.0$ equiv) and $\mathrm{K}_{2} \mathrm{CO}_{3}(829 \mathrm{mg}, 6.0 \mathrm{mmol}, 2.0$ equiv). $\mathrm{MeCN}(15 \mathrm{~mL})$ was added, followed by 3 -fluorobenzyl bromide $(0.37 \mathrm{~mL}, 3.0 \mathrm{mmol}, 1.0$ equiv). The reaction was heated to $60{ }^{\circ} \mathrm{C}$ and stirred for $15 \mathrm{~h}$. The reaction was cooled to room temperature, diluted with water, and extracted with EtOAc 3x. The combined organic layers were washed with brine, dried over $\mathrm{MgSO}_{4}$, and purified on silica gel (10-30\% EtOAc/hexanes eluent) to afford the title compound as a white solid (765 $\mathrm{mg}, 90 \%)$.

${ }^{1} \mathbf{H}$ NMR $\left(400 \mathrm{MHz}, \mathrm{CDCl}_{3}\right) \delta 8.02(\mathrm{dd}, \mathrm{J}=4.6,1.7 \mathrm{~Hz}, 1 \mathrm{H}), 7.37(\mathrm{td}, \mathrm{J}=7.9,5.7 \mathrm{~Hz}, 1 \mathrm{H}), 7.25$

- 7.17 (m, 3H), $7.14(\mathrm{dd}, \mathrm{J}=8.1,1.7 \mathrm{~Hz}, 1 \mathrm{H}), 7.04$ (tdd, J = 8.6, 2.7, $0.9 \mathrm{~Hz}, 1 \mathrm{H}), 5.17(\mathrm{~s}, 2 \mathrm{H})$ ppm.

${ }^{13}$ C NMR $\left(151 \mathrm{MHz}, \mathrm{CDCl}_{3}\right) \delta 163.2\left(\mathrm{~d},{ }^{1} \mathrm{~J}_{\mathrm{C}-\mathrm{F}}=247.0 \mathrm{~Hz}\right), 152.0,142.1,138.3\left(\mathrm{~d},{ }^{3} \mathrm{~J}_{\mathrm{C}-\mathrm{F}}=7.4\right.$ $\mathrm{Hz}), 133.6,130.6\left(\mathrm{~d},{ }^{3} \mathrm{~J}_{\mathrm{C}-\mathrm{F}}=8.3 \mathrm{~Hz}\right), 123.5,122.5\left(\mathrm{~d},{ }^{4} \mathrm{~J}_{\mathrm{C}-\mathrm{F}}=3.0 \mathrm{~Hz}\right), 120.5,115.4\left(\mathrm{~d},{ }^{2} \mathrm{~J}_{\mathrm{C}-\mathrm{F}}=21.2\right.$ $\mathrm{Hz}), 114.1\left(\mathrm{~d},{ }^{2} \mathrm{~J}_{\mathrm{C}-\mathrm{F}}=22.6 \mathrm{~Hz}\right), 70.3\left(\mathrm{~d},{ }^{4} \mathrm{~J}_{\mathrm{C}-\mathrm{F}}=2.1 \mathrm{~Hz}\right) \mathrm{ppm}$.

${ }^{19}$ F NMR $\left(376 \mathrm{MHz}, \mathrm{CDCl}_{3}\right) \delta-112.2(\mathrm{td}, \mathrm{J}=9.1,5.9 \mathrm{~Hz}) \mathrm{ppm}$.

LRMS (APCI) m/z: $[\mathrm{M}+\mathrm{H}]^{+}$calc'd. for $\mathrm{C}_{12} \mathrm{H}_{10} \mathrm{BrFNO}, 282.0$; found 281.8<smiles>Fc1cccc(F)c1COc1cccnc1Br</smiles>

2-bromo-3-((2,6-difluorobenzyl)oxy)pyridine (S35): A round bottom flask was charged with 2-bromo-3-hydroxypyridine (522 mg, $3.0 \mathrm{mmol}, 1.0$ equiv) and $\mathrm{K}_{2} \mathrm{CO}_{3}(829 \mathrm{mg}, 6.0 \mathrm{mmol}, 2.0$ equiv). MeCN (15 mL) was added, followed by 2,6-difluorobenzyl bromide (621 mg, $3.0 \mathrm{mmol}$, 1.0 equiv). The reaction was heated to $60{ }^{\circ} \mathrm{C}$ and stirred for $15 \mathrm{~h}$. The reaction was cooled to room temperature, diluted with water, and extracted with EtOAc 3x. The combined organic layers were washed with brine and dried over $\mathrm{MgSO}_{4}$ to afford the title compound as an offwhite solid (868 mg, 96\%).

${ }^{1} \mathbf{H}$ NMR $\left(400 \mathrm{MHz}, \mathrm{CDCl}_{3}\right) \delta 8.04-8.00(\mathrm{~m}, 1 \mathrm{H}), 7.41-7.31(\mathrm{~m}, 2 \mathrm{H}), 7.25-7.21(\mathrm{~m}, 1 \mathrm{H})$, $6.96(\mathrm{dd}, \mathrm{J}=8.3,7.4 \mathrm{~Hz}, 2 \mathrm{H}), 5.22(\mathrm{~s}, 2 \mathrm{H})$.

${ }^{13} \mathrm{C}$ NMR $\left(151 \mathrm{MHz}, \mathrm{CDCl}_{3}\right) \delta 162.1\left(\mathrm{dd},{ }^{1} \mathrm{~J}_{\mathrm{C}-\mathrm{F}}=251.6,{ }^{3} \mathrm{~J}_{\mathrm{C}-\mathrm{F}}=7.3 \mathrm{~Hz}\right), 152.2,142.4,134.0$, $131.5\left(\mathrm{t},{ }^{3} \mathrm{~J}_{\mathrm{C}-\mathrm{F}}=10.5 \mathrm{~Hz}\right), 123.5,121.4,111.8\left(\mathrm{dd},{ }^{2} \mathrm{~J}_{\mathrm{C}-\mathrm{F}}=21.0,{ }^{4} \mathrm{~J}_{\mathrm{C}-\mathrm{F}}=4.8 \mathrm{~Hz}\right), 111.7\left(\mathrm{t},{ }^{2} \mathrm{~J}_{\mathrm{C}-\mathrm{F}}=\right.$ $18.8 \mathrm{~Hz}), 59.6\left(\mathrm{t},{ }^{3} \mathrm{~J}_{\mathrm{C}-\mathrm{F}}=3.7 \mathrm{~Hz}\right) \mathrm{ppm}$.

${ }^{19}$ F NMR $\left(376 \mathrm{MHz}, \mathrm{CDCl}_{3}\right) \delta-114.1(\mathrm{t}, \mathrm{J}=6.8 \mathrm{~Hz}) \mathrm{ppm}$.

LRMS (APCI) m/z: $[\mathrm{M}+\mathrm{H}]^{+}$calc'd. for $\mathrm{C}_{12} \mathrm{H}_{9} \mathrm{BrF}_{2} \mathrm{NO}, 300.0$; found 299.8 


\section{Preparation of Products from the Substrate Table}

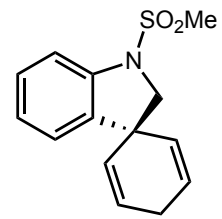

1'-(methylsulfonyl)spiro[cyclohexane-1,3'-indoline]-2,5-diene (9): Prepared according to General Procedure A using $N$-benzyl- $N$-(2 iodophenyl) methanesulfonamide (S3) (145 mg, 0.4 mmol, 1.0 equiv), DIPEA (210 $\mu \mathrm{L}, 1.2 \mathrm{mmol}, 3$ equiv) and 3DPAFIPN (11.8 mg, $5 \mathrm{~mol} \%)$. After $16 \mathrm{~h}$, the reaction was purified on silica $(10-30 \%$ EtOAc/hexanes) to provide the desired product as a colorless oil $(63.3 \mathrm{mg}, 65 \%$ yield $)$.

${ }^{1}$ H NMR $\left(500 \mathrm{MHz}, \mathrm{CDCl}_{3}\right) \delta 7.41(\mathrm{~d}, J=8.1,0.7 \mathrm{~Hz}, 1 \mathrm{H}), 7.22(\mathrm{ddd}, J=8.0,5.2,3.5 \mathrm{~Hz}, 1 \mathrm{H})$, $7.08-7.03$ (m, 3H), 5.91 (dtt, $J=10.3,3.4,1.1 \mathrm{~Hz}, 3 \mathrm{H}), 5.69$ (app. dp, $J=10.4,2.3 \mathrm{~Hz}, 2 \mathrm{H}$ ), $3.81(\mathrm{~s}, 2 \mathrm{H}), 2.92(\mathrm{~s}, 3 \mathrm{H}), 2.85-2.70(\mathrm{~m}, 3 \mathrm{H})$.

${ }^{13} \mathrm{C}$ NMR $\left(126 \mathrm{MHz}_{\mathrm{CDCl}}\right) \delta 140.3,138.1,128.6,128.6,125.5,124.7,124.1,113.3,63.4$, 45.2, 34.5, 25.9 .

HRMS (ESI) m/z: $[\mathrm{M}+\mathrm{H}]^{+}$calc'd. for $\mathrm{C}_{14} \mathrm{H}_{16} \mathrm{NO}_{2} \mathrm{~S}, 262.0902$, found 262.0884.<smiles>CCCCC=CC1(C(=O)c2ccccc2)C=CCC=C1</smiles>

tert-butyl spiro[cyclohexane-1,3'-indoline]-2,5-diene-1'-carboxylate (10): Prepared according to General Procedure A using tert-butyl benzyl(2-bromophenyl)carbamate

(S4) $(69 \mathrm{mg}, 0.2 \mathrm{mmol}, 1$ equiv), DIPEA (105 $\mu \mathrm{L}, 0.6 \mathrm{mmol}, 3$ equiv) and 3DPAFIPN (16.2 mg, $5 \mathrm{~mol} \%)$. After $16 \mathrm{~h}$, the reaction was purified on silica (0-5\% EtOAc/hexanes) to provide the desired product as a light yellow oil (47 $\mathrm{mg}, 79 \%$ yield).

${ }^{1} \mathbf{H}$ NMR $\left(600 \mathrm{MHz}, \mathrm{CDCl}_{3}\right) \delta 7.68(\mathrm{bs}, 1 \mathrm{H}), 7.20(\mathrm{ddd}, J=8.3,7.4,1.5 \mathrm{~Hz}, 1 \mathrm{H}), 7.02(\mathrm{dd}, J=$ $7.5,1.3 \mathrm{~Hz}, 1 \mathrm{H}), 6.97(\mathrm{td}, J=7.4,1.1 \mathrm{~Hz}, 1 \mathrm{H}), 5.87(\mathrm{dt}, J=10.2,3.4 \mathrm{~Hz}, 2 \mathrm{H}), 5.71(\mathrm{dt}, J=10.3$, $2.0 \mathrm{~Hz}, 2 \mathrm{H}), 3.87(\mathrm{~s}, 2 \mathrm{H}), 2.81$ (dddd, $J=23.1,5.4,3.3,2.1 \mathrm{~Hz}, 1 \mathrm{H}), 2.74$ (dtt, $J=23.2,3.5,2.0$ $\mathrm{Hz}, 1 \mathrm{H}), 1.60(\mathrm{~s}, 9 \mathrm{H})$.

${ }^{13}$ C NMR $\left(151 \mathrm{MHz}, \mathrm{CDCl}_{3}\right) \delta 152.4,141.1,138.1,130.0,128.0,124.8,123.4,122.7,114.7$, $80.9,61.7,44.5,28.5,25.9$.

HRMS (ESI) m/z: [M+H] $]^{+}$calc'd. for $\mathrm{C}_{18} \mathrm{H}_{22} \mathrm{NO}_{2}, 284.1650$; found 284.1657<smiles>CN1C(=O)C2(C=CCC=C2)c2ccccc21</smiles>

1'-methylspiro[cyclohexane-1,3'-indoline]-2,5-dien-2'-one (11): Prepared according to General Procedure A using $N$-(2-iodophenyl)- $N$-methylbenzamide (S6) (165 mg, 0.5 mmol, 1.0 equiv), DIPEA ( $260 \mu \mathrm{L}, 1.5 \mathrm{mmol}, 3$ equiv) and 3DPAFIPN (14 mg, $4 \mathrm{~mol} \%)$. After $16 \mathrm{~h}$, the reaction was purified on silica (10-20\% EtOAc/hexanes) to provide the desired product as a white solid (58 mg, 55\% yield). 
${ }^{1} \mathbf{H}$ NMR $\left(500 \mathrm{MHz}, \mathrm{CDCl}_{3}\right) \delta 7.29(\mathrm{tt}, J=7.7,1.2 \mathrm{~Hz}, 1 \mathrm{H}), 7.14-7.11(\mathrm{~m}, 1 \mathrm{H}), 7.06(\mathrm{tt}, J=$ 7.4, $1.0 \mathrm{~Hz}, 1 \mathrm{H}), 6.85$ (d, $J=7.8,0.8 \mathrm{~Hz}, 1 \mathrm{H}), 6.14$ (dtd, $J=10.3,3.4,0.9 \mathrm{~Hz}, 2 \mathrm{H}), 5.39$ (dtd, $J=$ $10.5,2.0,0.9 \mathrm{~Hz}, 2 \mathrm{H}), 3.23(\mathrm{~s}, 3 \mathrm{H}), 3.02-2.94(\mathrm{~m}, 1 \mathrm{H}), 2.90-2.81(\mathrm{~m}, 1 \mathrm{H})$.

${ }^{13} \mathbf{C}$ NMR $\left(126 \mathrm{MHz}, \mathrm{CDCl}_{3}\right) \delta 177.9,143.0,134.2,128.4,127.3,124.7,123.8,122.9,108.0$, $51.8,26.6,25.7$.

HRMS (ESI) m/z: [M+H] $]^{+}$calc'd. for $\mathrm{C}_{14} \mathrm{H}_{14} \mathrm{NO}, 212.1075$; found 212.1118 .

${ }^{1} \mathrm{H}$ NMR spectrum is consistent with reported values ${ }^{10}$

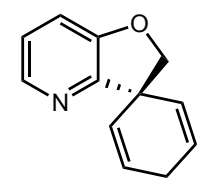

2' $H$-spiro[cyclohexane-1,3'-furo[3,2-b]pyridine]-2,5-diene (12): Prepared according to General Procedure A using 3-(benzyloxy)-2-bromopyridine (S7) (128 mg, $0.5 \mathrm{mmol}, 1$ equiv), DIPEA $(270 \mu \mathrm{L}, 1.5 \mathrm{mmol}, 3$ equiv) and 3DPAFIPN (18 mg, $6 \mathrm{~mol} \%)$. After $16 \mathrm{~h}$, the reaction was purified on silica $\left(20-40 \% \mathrm{Et}_{2} \mathrm{O} /\right.$ hexanes $)$ to provide the desired product as a colorless oil (65 mg, 72\% yield).

${ }^{1} \mathbf{H}$ NMR $\left(600 \mathrm{MHz}, \mathrm{CDCl}_{3}\right) \delta 8.14(\mathrm{dd}, J=4.7,1.4 \mathrm{~Hz}, 1 \mathrm{H}), 7.09(\mathrm{dd}, J=8.1,1.4 \mathrm{~Hz}, 1 \mathrm{H}), 7.05$ (dd, $J=8.1,4.7 \mathrm{~Hz}, 1 \mathrm{H}), 6.02$ (dt, $J=10.2,3.4 \mathrm{~Hz}, 2 \mathrm{H}), 5.75(\mathrm{dt}, J=10.3,2.0 \mathrm{~Hz}, 2 \mathrm{H}), 4.46$ (s, 2H), $2.93(\mathrm{dtt}, J=23.3,3.3,2.1 \mathrm{~Hz}, 1 \mathrm{H}), 2.74(\mathrm{dtt}, J=23.4,3.5,2.1 \mathrm{~Hz}, 1 \mathrm{H})$.

${ }^{13}$ C NMR (151 MHz, $\left.\mathrm{CDCl}_{3}\right) \delta 155.1,152.6,142.8,127.0,125.8,122.8,116.6,83.0,47.6,26.0$ HRMS (ESI) m/z: [M+H] $]^{+}$calc'd. for $\mathrm{C}_{12} \mathrm{H}_{12} \mathrm{NO}, 186.0918$; found 186.1081 .

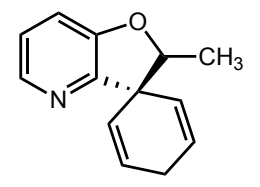

2'-methyl-2' $H$-spiro[cyclohexane-1,3'-furo[3,2-b]pyridine]-2,5-diene (13): Prepared according to General Procedure B using 2-bromo-3-(1-phenylethoxy)pyridine (S8) (152 mg, 0.6 mmol, 1 equiv), DIPEA( $1.1 \mathrm{~mL}, 6.2 \mathrm{mmol}, 10$ equiv) and 3DPAFIPN (17 mg, $4 \mathrm{~mol} \%)$.. After $16 \mathrm{~h}$, the reaction was purified on silica (15-20\% EtOAc/hexanes) to provide the desired product as a yellow oil ( $54 \mathrm{mg}, 50 \%$ yield).

${ }^{1}$ H NMR $\left(600 \mathrm{MHz}, \mathrm{CDCl}_{3}\right) \delta 8.12(\mathrm{dd}, J=4.5,1.7 \mathrm{~Hz}, 1 \mathrm{H}), 7.07(\mathrm{dd}, J=8.1,1.7 \mathrm{~Hz}, 1 \mathrm{H}), 7.04$ (dd, $J=8.1,4.5 \mathrm{~Hz}, 1 \mathrm{H}), 6.15$ (dtd, $J=10.0,3.4,1.6 \mathrm{~Hz}, 1 \mathrm{H}), 5.98$ (dtd, $J=10.1,3.4,1.6 \mathrm{~Hz}$, $1 \mathrm{H}), 5.67(\mathrm{dq}, J=10.0,2.1 \mathrm{~Hz}, 1 \mathrm{H}), 5.59(\mathrm{dq}, J=10.1,2.1 \mathrm{~Hz}, 1 \mathrm{H}), 4.57(\mathrm{q}, J=6.6 \mathrm{~Hz}, 1 \mathrm{H})$, $2.91(\mathrm{dtt}, J=23.4,3.7,2.0 \mathrm{~Hz}, 1 \mathrm{H}), 2.76(\mathrm{dtt}, J=23.3,3.2,2.2 \mathrm{~Hz}, 1 \mathrm{H}), 1.42(\mathrm{~d}, J=6.6 \mathrm{~Hz}$, $3 \mathrm{H})$.

${ }^{13} \mathbf{C}$ NMR $\left(151 \mathrm{MHz}, \mathrm{CDCl}_{3}\right) \delta 156.3,152.4,142.7,127.9,126.4,125.9,124.5,122.8,116.4$, $88.7,50.7,26.3,15.2$.

HRMS (ESI) m/z: $[\mathrm{M}+\mathrm{H}]^{+}$calc'd. for $\mathrm{C}_{13} \mathrm{H}_{14} \mathrm{NO}$, 200.1075; found 200.1184 
<smiles>C1=CC2(C=C1)CCOc1cccnc12</smiles>

2',3'-dihydrospiro[cyclohexane-1,4'-pyrano[3,2-b]pyridine]-2,5-diene (14): Prepared according to General Procedure A using 2-bromo-3-phenethoxypyridine (S9) (59 mg, $0.2 \mathrm{mmol}$, 1 equiv) DIPEA(105 $\mu \mathrm{L}, 0.6 \mathrm{mmol}, 3$ equiv) and 3DPAFIPN ( $6 \mathrm{mg}, 5 \mathrm{~mol} \%)$. After $16 \mathrm{~h}$, the reaction was purified on silica $(20-30 \%$ EtOAc/hexanes) to provide the desired product as a colorless oil (18 mg, $46 \%$ yield).

${ }^{1}$ H NMR $\left(500 \mathrm{MHz}, \mathrm{CDCl}_{3}\right) \delta 8.24(\mathrm{dd}, J=4.5,1.5 \mathrm{~Hz}, 1 \mathrm{H}), 7.12(\mathrm{dd}, J=8.2,1.5 \mathrm{~Hz}, 1 \mathrm{H}), 7.05$ $(\mathrm{dd}, J=8.2,4.5 \mathrm{~Hz}, 1 \mathrm{H}), 5.96(\mathrm{dt}, J=10.3,3.4 \mathrm{~Hz}, 2 \mathrm{H}), 5.77(\mathrm{dt}, J=10.4,2.0 \mathrm{~Hz}, 2 \mathrm{H}), 4.35-$ $4.19(\mathrm{~m}, 2 \mathrm{H}), 2.92$ (dtt, $J=23.0,3.6,1.8 \mathrm{~Hz}, 1 \mathrm{H}), 2.73$ (dddd, $J=23.0,5.5,3.1,2.4 \mathrm{~Hz}, 1 \mathrm{H}$ ), $2.11-2.01(\mathrm{~m}, 2 \mathrm{H})$.

${ }^{13} \mathrm{C}$ NMR $\left(151 \mathrm{MHz}, \mathrm{CDCl}_{3}\right) \delta 150.4,148.4,142.4,131.0,124.4,124.4,122.8,77.2,77.0,76.8$, $62.4,39.3,37.4,26.2$.

HRMS (ESI) m/z: $[\mathrm{M}+\mathrm{H}]^{+}$calc'd. for $\mathrm{C}_{13} \mathrm{H}_{14} \mathrm{NO}, 200.1075$, found 200.1247 .<smiles>Cc1cccc2c1C1(C=CCC=C1)C(=O)N2C</smiles>

1',4'-dimethylspiro[cyclohexane-1,3'-indoline]-2,5-dien-2'-one (15): Prepared according to General Procedure A using $N$-(2-bromo-3-methylphenyl)- $N$-methylbenzamide (S11) (170 mg, $0.6 \mathrm{mmol}, 1$ equiv), DIPEA(300 $\mu \mathrm{L}, 1.7 \mathrm{mmol}, 3$ equiv) and 3DPAFIPN (15 mg, $4 \mathrm{~mol} \%$ ). After $16 \mathrm{~h}$, the reaction was purified on silica ( $20 \%$ EtOAc/hexanes) to provide the desired product as a yellow solid (106 $\mathrm{mg}, 84 \%$ yield).

${ }^{1} \mathbf{H}$ NMR $\left(600 \mathrm{MHz}, \mathrm{CDCl}_{3}\right) \delta 7.22(\mathrm{t}, J=7.8 \mathrm{~Hz}, 1 \mathrm{H}), 6.85(\mathrm{dt}, J=7.8,0.8 \mathrm{~Hz}, 1 \mathrm{H}), 6.72(\mathrm{dt}, J$ $=7.7,0.8 \mathrm{~Hz}, 1 \mathrm{H}), 6.17(\mathrm{dt}, J=10.3,3.4 \mathrm{~Hz}, 2 \mathrm{H}), 5.36(\mathrm{dt}, J=10.3,2.0 \mathrm{~Hz}, 2 \mathrm{H}), 3.23(\mathrm{~s}, 3 \mathrm{H})$, $3.04(\mathrm{dtt}, J=23.3,3.4,2.1 \mathrm{~Hz}, 1 \mathrm{H}), 2.82(\mathrm{dtt}, J=23.2,3.4,2.1 \mathrm{~Hz}, 1 \mathrm{H}), 2.22(\mathrm{~s}, 3 \mathrm{H})$.

${ }^{13}$ C NMR $\left(151 \mathrm{MHz}, \mathrm{CDCl}_{3}\right) \delta 177.6,143.1,136.0,130.1,128.3,127.7,125.1,122.7,105.7$, $51.8,26.7,25.8,16.7$.

HRMS (ESI) m/z: [M+H] $]^{+}$calc'd. for $\mathrm{C}_{15} \mathrm{H}_{16} \mathrm{NO}, 226.1232$; found 226.1323 .<smiles>Cc1ccc2c(c1)N(C)C(=O)C21C=CCC=C1</smiles>

\section{1',6'-dimethylspiro[cyclohexane-1,3'-indoline]-2,5-dien-2'-one (16)}

Prepared according to General Procedure A using N-(2-bromo-5-methylphenyl)-Nmethylbenzamide (S13) (152 mg, $0.5 \mathrm{mmol}, 1$ equiv), DIPEA (280 $\mu \mathrm{L}, 1.5 \mathrm{mmol}, 3$ equiv) and 3DPAFIPN (15 mg, $5 \mathrm{~mol} \%$ ).After $16 \mathrm{~h}$, purification via preparative HPLC on an Agilent 1200 Infinity Series chromatograph using an Agilent PrepC18 30 x $250 \mathrm{~mm} 10 \mu \mathrm{m}$ column, with a linear gradient using water and $0.1 \%$ formic acid (FA) (Solvent A) and MeCN and 0.1\% FA 
(Solvent $\mathrm{B}$ ); $\mathrm{t}=0 \mathrm{~min}, 50 \% \mathrm{~B}, \mathrm{t}=25 \mathrm{~min}, 99 \% \mathrm{~B}$, with a flow rate $40 \mathrm{~mL} / \mathrm{min}$, to provide the desired product as a light yellow solid $(80.0 \mathrm{mg}, 71 \%$ yield $)$.

${ }^{1}$ H NMR $\left(400 \mathrm{MHz}, \mathrm{CDCl}_{3}\right) \delta 7.00(\mathrm{~d}, \mathrm{~J}=7.5 \mathrm{~Hz}, 1 \mathrm{H}), 6.87(\mathrm{ddd}, \mathrm{J}=7.4,1.5,0.8 \mathrm{~Hz}, 1 \mathrm{H}), 6.67$ $(\mathrm{dd}, \mathrm{J}=1.6,0.8 \mathrm{~Hz}, 1 \mathrm{H}), 6.16-6.07(\mathrm{~m}, 2 \mathrm{H}), 5.37(\mathrm{dt}, \mathrm{J}=10.3,2.0 \mathrm{~Hz}, 2 \mathrm{H}), 3.21(\mathrm{~s}, 3 \mathrm{H}), 2.97$ (dtt, J = 23.3, 3.3, 2.2 Hz, 1H), 2.84 (dtt, J = 23.2, 3.6, 2.0 Hz, 1H), 2.39 (d, J = 0.7 Hz, 3H) ppm. ${ }^{13} \mathrm{C}$ NMR $\left(126 \mathrm{MHz}, \mathrm{CDCl}_{3}\right) \delta 178.3,143.2,138.8,131.5,127.2,124.6,124.2,123.5,109.1$, 51.7, 26.7, 25.9, $21.9 \mathrm{ppm}$.

HRMS (ESI) m/z: [M+H] $]^{+}$calc'd. for $\mathrm{C}_{15} \mathrm{H}_{16} \mathrm{NO}, 226.1232$; found 226.1303.

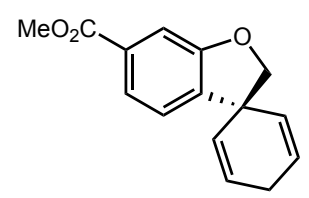

methyl $2 H$-spiro[benzofuran-3,1'-cyclohexane]-2',5'-diene-6-carboxylate (17): Prepared according to General Procedure A using methyl 3-(benzyloxy)-4-iodobenzoate

(S14) (156 mg, $0.4 \mathrm{mmol}, 1$ equiv), DIPEA (260 $\mu \mathrm{L}, 1.5 \mathrm{mmol}, 3$ equiv) and 3DPAFIPN (17 $\mathrm{mg}, 5 \mathrm{~mol} \%)$. After $16 \mathrm{~h}$, the reaction was purified on silica $(10-30 \%$ EtOAc/hexanes $)$ to provide the desired product as a yellow oil (66 $\mathrm{mg}, 64 \%$ yield).

${ }^{1}$ H NMR $\left(500 \mathrm{MHz}, \mathrm{CDCl}_{3}\right) \delta 7.60(\mathrm{dd}, J=7.8,1.5 \mathrm{~Hz}, 1 \mathrm{H}), 7.44(\mathrm{~d}, J=1.5 \mathrm{~Hz}, 1 \mathrm{H}), 7.06(\mathrm{~d}, J$ $=7.7 \mathrm{~Hz}, 1 \mathrm{H}), 5.90(\mathrm{dt}, J=10.1,3.4 \mathrm{~Hz}, 2 \mathrm{H}), 5.70(\mathrm{dt}, J=10.2,2.0 \mathrm{~Hz}, 2 \mathrm{H}), 4.39(\mathrm{~s}, 2 \mathrm{H}), 3.89$ (s, 3H), 2.81 (dddd, $J=23.3,5.4,3.2,2.1 \mathrm{~Hz}, 1 \mathrm{H}), 2.72$ (dtt, $J=23.3,3.5,2.1 \mathrm{~Hz}, 1 \mathrm{H})$. ${ }^{13} \mathrm{C}$ NMR $\left(151 \mathrm{MHz}, \mathrm{CDCl}_{3}\right) \delta 166.9,159.0,139.7,130.8,128.3,124.6,124.6,123.1,110.7$, 83.7, 77.2, 77.0, 76.8, 52.1, 47.4, 25.9.

HRMS (ESI) m/z: $[\mathrm{M}+\mathrm{H}]^{+}$calc'd. for $\mathrm{C}_{15} \mathrm{H}_{15} \mathrm{O}_{3}, 243.1021$; found 243.1062.

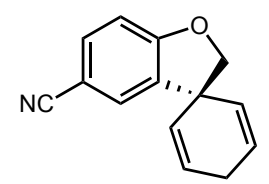

2H-spiro[benzofuran-3, 1'-cyclohexane]-2',5'-diene-5-carbonitrile (18): Prepared according to General Procedure B using 4-(benzyloxy)-3-chlorobenzonitrile (S15) (119 mg, 0.5 mmol, 1 equiv), ) DIPEA (900 $\mu \mathrm{L}, 5.2 \mathrm{mmol}, 10$ equiv) and 3DPAFIPN (18 mg, $6 \mathrm{~mol} \%$ ). After $16 \mathrm{~h}$, the reaction was purified on silica $(5 \%$ EtOAc/hexanes) to provide the desired product as a yellow solid (55 $\mathrm{mg}, 54 \%$ yield).

${ }^{1}$ H NMR $\left(600 \mathrm{MHz}, \mathrm{CDCl}_{3}\right) \delta 7.47(\mathrm{dd}, J=8.3,1.8 \mathrm{~Hz}, 1 \mathrm{H}), 7.31(\mathrm{~d}, J=1.8 \mathrm{~Hz}, 1 \mathrm{H}), 6.86(\mathrm{~d}, J$ $=8.3 \mathrm{~Hz}, 1 \mathrm{H}), 5.94(\mathrm{dt}, J=10.1,3.4 \mathrm{~Hz}, 2 \mathrm{H}), 5.69(\mathrm{dt}, J=10.2,2.0 \mathrm{~Hz}, 2 \mathrm{H}), 4.44(\mathrm{~s}, 2 \mathrm{H}), 2.83$ (dddd, $J=23.4,5.4,3.4,2.1 \mathrm{~Hz}, 1 \mathrm{H}), 2.75$ (dtt, $J=23.4,3.7,2.0 \mathrm{~Hz}, 1 \mathrm{H})$.

${ }^{13}$ C NMR $\left(151 \mathrm{MHz}, \mathrm{CDCl}_{3}\right) \delta 162.4,136.1,133.8,129.3,127.9,125.1,119.4,110.7,104.3$, 84.3, 47.0, 25.8 .

HRMS (ESI) m/z: [M+H] $]^{+}$calc'd. for $\mathrm{C}_{14} \mathrm{H}_{12} \mathrm{NO}, 210.0919$; found 210.0954.<smiles>CC1(C)CC2(C=CCC=C2)c2cccnc21</smiles>

tert-butyl spiro[cyclohexane-1,3'-pyrrolo[2,3-b]pyridine]-2,5-diene-1'(2'H)-carboxylate (19): Prepared according to General Procedure A using tert-butyl benzyl(3-bromopyridin-2- 
yl)carbamate (S17) (182 mg, $0.5 \mathrm{mmol}, 1$ equiv), DIPEA (260 $\mu \mathrm{L}, 1.5 \mathrm{mmol}, 3$ equiv) and 3DPAFIPN (16 mg, $5 \mathrm{~mol} \%)$. After $16 \mathrm{~h}$, the reaction was purified on silica $(10-30 \%$ EtOAc/hexanes) to provide the desired product as a yellow oil (109 $\mathrm{mg}, 77 \%$ yield).

${ }^{1} \mathbf{H}$ NMR $\left(600 \mathrm{MHz}, \mathrm{CDCl}_{3}\right) \delta 8.25(\mathrm{dd}, \mathrm{J}=5.1,1.7 \mathrm{~Hz}, 1 \mathrm{H}), 7.27-7.23(\mathrm{~m}, 1 \mathrm{H}), 6.84(\mathrm{dd}, \mathrm{J}=$ 7.4, $5.1 \mathrm{~Hz}, 1 \mathrm{H}), 5.88(\mathrm{dt}, \mathrm{J}=10.2,3.4 \mathrm{~Hz}, 2 \mathrm{H}), 5.65(\mathrm{dt}, \mathrm{J}=10.3,2.0 \mathrm{~Hz}, 2 \mathrm{H}), 3.85(\mathrm{~s}, 2 \mathrm{H})$, $2.78(\mathrm{dtt}, \mathrm{J}=23.3,3.3,2.1 \mathrm{~Hz}, 1 \mathrm{H}), 2.72(\mathrm{dtt}, \mathrm{J}=23.3,3.4,2.1 \mathrm{~Hz}, 1 \mathrm{H}), 1.55(\mathrm{~s}, 9 \mathrm{H}) \mathrm{ppm}$. ${ }^{13} \mathrm{C}$ NMR $\left(151 \mathrm{MHz}, \mathrm{CDCl}_{3}\right) \delta 155.4,151.0,148.1,133.3,131.7,129.2,124.4,118.1,81.6$, $60.9,42.5,28.5,26.0 \mathrm{ppm}$.

HRMS (ESI) m/z: [M+H] $]^{+}$calc'd. for $\mathrm{C}_{17} \mathrm{H}_{21} \mathrm{~N}_{2} \mathrm{O}_{2}, 285.1603$; found 285.1752 .

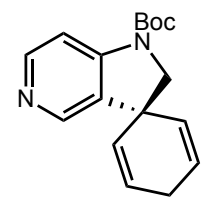

tert-butyl spiro[cyclohexane-1,3'-pyrrolo[3,2-c]pyridine]-2,5-diene-1'(2'H)-carboxylate (20): Prepared according to General Procedure A using tert-butyl benzyl(3-bromopyridin-4yl)carbamate (S19) (182 mg, $0.5 \mathrm{mmol}, 1$ equiv), DIPEA ( $260 \mu \mathrm{L}, 1.5 \mathrm{mmol}, 3$ equiv) and 3DPAFIPN (16 mg, $5 \mathrm{~mol} \%)$. After $16 \mathrm{~h}$, the reaction was purified on silica $(20-30 \%$ EtOAc/hexanes) to provide the desired product as a yellow oil (127 mg, 89\% yield). ${ }^{1} \mathbf{H}$ NMR $\left(600 \mathrm{MHz}, \mathrm{CDCl}_{3}\right) \delta 8.35(\mathrm{~d}, \mathrm{~J}=5.5 \mathrm{~Hz}, 1 \mathrm{H}), 8.12(\mathrm{~d}, \mathrm{~J}=0.8 \mathrm{~Hz}, 1 \mathrm{H}), 7.67(\mathrm{~s}, 1 \mathrm{H})$, $5.88(\mathrm{dt}, \mathrm{J}=10.1,3.4 \mathrm{~Hz}, 2 \mathrm{H}), 5.67(\mathrm{dt}, \mathrm{J}=10.3,2.0 \mathrm{~Hz}, 2 \mathrm{H}), 3.85$ (s, 2H), 2.81 (dddd, J = 23.3, 5.4, 3.3, 2.1 Hz, 1H), 2.73 (dtt, J = 23.4, 3.8, 2.1 Hz, 1H), 1.57 (s, 9H) ppm.

${ }^{13}$ C NMR $\left(151 \mathrm{MHz}, \mathrm{CDCl}_{3}\right) \delta 152.0,149.8,148.1,146.7,133.8,129.2,124.3,109.5,82.3$, 62.2, 43.4, 28.5, $25.9 \mathrm{ppm}$.

HRMS (ESI) m/z: $[\mathrm{M}+\mathrm{H}]^{+}$calc'd. for $\mathrm{C}_{17} \mathrm{H}_{21} \mathrm{~N}_{2} \mathrm{O}_{2}, 285.1603$; found 285.1696

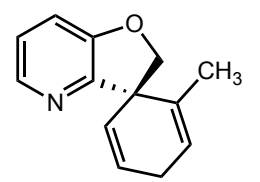

2-methyl-2' H-spiro[cyclohexane-1,3'-furo[3,2-b]pyridine]-2,5-diene (21): Prepared according to General Procedure A using 2-bromo-3-((2-methylbenzyl)oxy)pyridine (S20) (156 mg, $0.6 \mathrm{mmol}, 1$ equiv) DIPEA (260 $\mu \mathrm{L}, 1.5 \mathrm{mmol}, 3$ equiv) and 3DPAFIPN (16 $\mathrm{mg}, 4 \mathrm{~mol} \%)$. After $16 \mathrm{~h}$, the reaction was purified on silica (15-30\% EtOAc/hexanes) to provide the desired product as a yellow oil ( $97 \mathrm{mg}, 87 \%$ yield).

${ }^{1}$ H NMR $\left(600 \mathrm{MHz}, \mathrm{CDCl}_{3}\right) \delta 8.14(\mathrm{dd}, J=4.7,1.5 \mathrm{~Hz}, 1 \mathrm{H}), 7.07(\mathrm{dd}, J=8.1,1.6 \mathrm{~Hz}, 1 \mathrm{H}), 7.04$ $(\mathrm{dd}, J=8.1,4.6 \mathrm{~Hz}, 1 \mathrm{H}), 6.00(\mathrm{dtd}, J=9.9,3.4,1.5 \mathrm{~Hz}, 1 \mathrm{H}), 5.71-5.67(\mathrm{~m}, 2 \mathrm{H}), 4.65(\mathrm{~d}, J=$ $9.3 \mathrm{~Hz}, 1 \mathrm{H}), 4.37$ (d, $J=9.3 \mathrm{~Hz}, 1 \mathrm{H}), 2.91(\mathrm{dtt}, J=23.3,3.7,1.9 \mathrm{~Hz}, 1 \mathrm{H}), 2.73$ (dtt, $J=23.3$, $3.4,1.9 \mathrm{~Hz}, 1 \mathrm{H}), 1.53(\mathrm{q}, J=1.8 \mathrm{~Hz}, 3 \mathrm{H})$.

${ }^{13} \mathbf{C}$ NMR $\left(151 \mathrm{MHz}, \mathrm{CDCl}_{3}\right) \delta 154.5,153.3,142.8,132.0,127.7,125.6,122.7,122.2,116.6$, 81.5, 50.6, 27.0, 19.0.

HRMS (ESI) m/z: [M+H] ${ }^{+}$calc'd. for $\mathrm{C}_{13} \mathrm{H}_{14} \mathrm{NO}$, 200.1075; found 200.1057. 


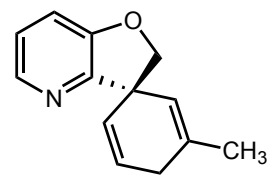

3-methyl-2' $H$-spiro[cyclohexane-1,3'-furo[3,2-b]pyridine]-2,5-diene (22): Prepared according to General Procedure A using 2-bromo-3-((3-methylbenzyl)oxy)pyridine (S21) (131 mg, $0.5 \mathrm{mmol}, 1$ equiv), DIPEA (260 $\mu \mathrm{L}, 1.5 \mathrm{mmol}, 3$ equiv) and 3DPAFIPN (17 $\mathrm{mg}, 5 \mathrm{~mol} \%)$. After $16 \mathrm{~h}$, the reaction was purified on silica $(20-30 \%$ EtOAc/hexanes $)$ to provide the desired product as a light yellow solid (94 $\mathrm{mg}, 72 \%$ yield). ${ }^{1} \mathbf{H}$ NMR $\left(600 \mathrm{MHz}, \mathrm{CDCl}_{3}\right) \delta 8.12(\mathrm{dd}, J=4.8,1.4 \mathrm{~Hz}, 1 \mathrm{H}), 7.07(\mathrm{dd}, J=8.1,1.4 \mathrm{~Hz}, 1 \mathrm{H}), 7.03$ $(\mathrm{dd}, J=8.1,4.8 \mathrm{~Hz}, 1 \mathrm{H}), 5.99(\mathrm{dt}, J=9.9,3.4 \mathrm{~Hz}, 1 \mathrm{H}), 5.72(\mathrm{dq}, J=9.9,2.1 \mathrm{~Hz}, 1 \mathrm{H}), 5.46(\mathrm{p}, J$ $=1.7 \mathrm{~Hz}, 1 \mathrm{H}), 4.41(\mathrm{~d}, J=1.2 \mathrm{~Hz}, 2 \mathrm{H}), 2.82(\mathrm{~d}, J=23.2 \mathrm{~Hz}, 1 \mathrm{H}), 2.62(\mathrm{~d}, J=23.5 \mathrm{~Hz}, 1 \mathrm{H}), 1.79$ (s, 3H).

${ }^{13} \mathrm{C}$ NMR $\left(151 \mathrm{MHz}, \mathrm{CDCl}_{3}\right) \delta 155.4,152.6,142.7,133.4,126.9,125.7,122.7,121.8,116.5$, 83.1, 48.8, 30.8, 23.2.

HRMS (ESI) m/z: $[\mathrm{M}+\mathrm{H}]^{+}$calc'd. for $\mathrm{C}_{13} \mathrm{H}_{14} \mathrm{NO}, 200.1075$; found 200.1304

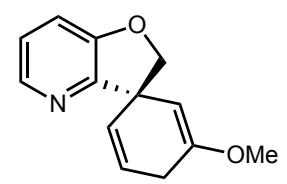

3-methoxy-2' $H$-spiro[cyclohexane-1,3'-furo[3,2-b]pyridine]-2,5-diene (23): Prepared according to General Procedure A using 2-bromo-3-((3-methoxybenzyl)oxy)pyridine (S22) (145 mg, 0.5 mmol, 1 equiv) DIPEA (260 $\mu \mathrm{L}, 1.5 \mathrm{mmol}, 3$ equiv) and 3DPAFIPN (16 mg, $5 \mathrm{~mol} \%$ ). After $16 \mathrm{~h}$, the reaction was purified on silica $(20-30 \% \mathrm{EtOAc} / \mathrm{hexanes})$ to provide the desired product as an orange solid ( $89 \mathrm{mg}, 84 \%$ yield).

${ }^{1}$ H NMR $\left(600 \mathrm{MHz}, \mathrm{CDCl}_{3}\right) \delta 8.14(\mathrm{dd}, J=4.8,1.4 \mathrm{~Hz}, 1 \mathrm{H}), 7.09(\mathrm{dd}, J=8.1,1.4 \mathrm{~Hz}, 1 \mathrm{H}), 7.05$ $(\mathrm{dd}, J=8.1,4.7 \mathrm{~Hz}, 1 \mathrm{H}), 5.91(\mathrm{dt}, J=9.9,3.5 \mathrm{~Hz}, 1 \mathrm{H}), 5.71(\mathrm{dq}, J=9.8,2.1 \mathrm{~Hz}, 1 \mathrm{H}), 4.69(\mathrm{q}, J$ $=1.3 \mathrm{~Hz}, 1 \mathrm{H}), 4.47(\mathrm{~d}, J=8.9 \mathrm{~Hz}, 1 \mathrm{H}), 4.42(\mathrm{~d}, J=9.0 \mathrm{~Hz}, 1 \mathrm{H}), 3.57(\mathrm{~s}, 3 \mathrm{H}), 2.97(\mathrm{~d}, J=22.0$ $\mathrm{Hz}, 1 \mathrm{H}), 2.78(\mathrm{~d}, J=22.0 \mathrm{~Hz}, 1 \mathrm{H})$.

${ }^{13}$ C NMR $\left(151 \mathrm{MHz}, \mathrm{CDCl}_{3}\right) \delta 155.6,154.7,152.5,142.8,127.4,124.2,122.7,116.6,95.5$, 83.7, 54.0, 49.6, 28.6.

HRMS (ESI) m/z: $[\mathrm{M}+\mathrm{H}]^{+}$calc'd. for $\mathrm{C}_{13} \mathrm{H}_{14} \mathrm{NO}_{2}, 216.1025$; found 216.1049

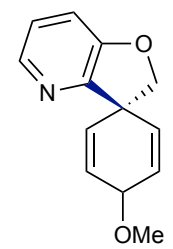

4-methoxy-2' $H$-spiro[cyclohexane-1,3'-furo[3,2-b]pyridine]-2,5-diene (24): Prepared according to General Procedure B using 2-bromo-3-((4-methoxybenzyl)oxy)pyridine (S23) (159 mg, $0.5 \mathrm{mmol}, 1$ equiv) DIPEA(900 $\mu \mathrm{L}, 5.2 \mathrm{mmol}, 10$ equiv) and 3DPAFIPN (19 $\mathrm{mg}, 5 \mathrm{~mol} \%)$. After $16 \mathrm{~h}$, the reaction was purified on silica $(20-50 \% \mathrm{EtOAc} / \mathrm{hexanes})$ to isolate a single diastereomer as a light yellow oil ( $72 \mathrm{mg}, 62 \%$ yield).

${ }^{1}$ H NMR $\left(600 \mathrm{MHz}, \mathrm{CDCl}_{3}\right) \delta 8.12(\mathrm{dd}, J=4.8,1.4 \mathrm{~Hz}, 1 \mathrm{H}), 7.13(\mathrm{dd}, J=8.1,1.4 \mathrm{~Hz}, 1 \mathrm{H}), 7.08$ $(\mathrm{dd}, J=8.1,4.8 \mathrm{~Hz}, 1 \mathrm{H}), 6.13(\mathrm{dd}, J=10.2,3.2 \mathrm{~Hz}, 2 \mathrm{H}), 6.02(\mathrm{dd}, J=10.1,1.6 \mathrm{~Hz}, 2 \mathrm{H}), 4.61$ $(\mathrm{tt}, J=3.2,1.6 \mathrm{~Hz}, 1 \mathrm{H}), 4.54(\mathrm{~s}, 2 \mathrm{H}), 3.39$ (s, 3H). 
${ }^{13}$ C NMR $\left(151 \mathrm{MHz}, \mathrm{CDCl}_{3}\right) \delta 153.3,153.1,142.8,130.7,126.6,123.2,117.0,80.7,69.2,54.4$, 48.5 .

HRMS (ESI) m/z: $[\mathrm{M}+\mathrm{H}]^{+}$calc'd. for $\mathrm{C}_{13} \mathrm{H}_{14} \mathrm{NO}_{2}, 216.1025$; found 216.1081 .

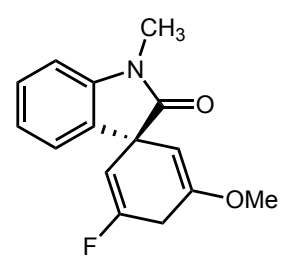

3-fluoro-5-methoxy-1'-methylspiro[cyclohexane-1,3'-indoline]-2,5-dien-2'-one (25):

Prepared according to General Procedure A using 3-fluoro- $N$-(2-iodophenyl)-5-methoxy- $N$ methylbenzamide (S25) (77 mg, $0.2 \mathrm{mmol}, 1$ equiv), DIPEA (105 $\mu \mathrm{L}, 0.6 \mathrm{mmol}, 3$ equiv) and 3DPAFIPN (6 mg, $5 \mathrm{~mol} \%)$. After $16 \mathrm{~h}$, the reaction was purified on silica $(10-30 \%$ EtOAc/hexanes) to provide the desired product as a yellow oil (35 $\mathrm{mg}, 68 \%$ yield).

${ }^{21} \mathbf{H}$ NMR $\left(400 \mathrm{MHz}, \mathrm{CDCl}_{3}\right) \delta 7.30(\mathrm{td}, \mathrm{J}=7.6,1.5 \mathrm{~Hz}, 1 \mathrm{H}), 7.13$ (ddd, J = 7.4, 1.5, $0.6 \mathrm{~Hz}$, $1 \mathrm{H}), 7.07(\mathrm{td}, \mathrm{J}=7.4,1.0 \mathrm{~Hz}, 1 \mathrm{H}), 6.85(\mathrm{dt}, \mathrm{J}=7.8,0.8 \mathrm{~Hz}, 1 \mathrm{H}), 4.98(\mathrm{dq}, \mathrm{J}=14.7,1.5 \mathrm{~Hz}, 1 \mathrm{H})$, $4.33(\mathrm{t}, \mathrm{J}=1.6 \mathrm{~Hz}, 1 \mathrm{H}), 3.54(\mathrm{~s}, 3 \mathrm{H}), 3.24(\mathrm{~s}, 3 \mathrm{H}), 3.24(\mathrm{dt}, \mathrm{J}=20.8,1.5 \mathrm{~Hz}, 1 \mathrm{H}), 3.09$ (dq, J = $21.0,1.3 \mathrm{~Hz}, 1 \mathrm{H}) \mathrm{ppm}$.

${ }^{13} \mathbf{C}$ NMR $\left(126 \mathrm{MHz}, \mathrm{CDCl}_{3}\right) \delta 178.2,158.9\left(\mathrm{~d},{ }^{1} \mathrm{~J}_{\mathrm{C}-\mathrm{F}}=257.2 \mathrm{~Hz}\right), 154.5\left(\mathrm{~d},{ }^{3} \mathrm{~J}_{\mathrm{C}-\mathrm{F}}=16.1 \mathrm{~Hz}\right)$, $142.8,133.9,128.7,124.8,123.2,101.6\left(\mathrm{~d},{ }^{2} \mathrm{~J}_{\mathrm{C}-\mathrm{F}}=18.4 \mathrm{~Hz}\right), 92.9,54.8,52.1\left(\mathrm{~d},{ }^{3} \mathrm{~J}_{\mathrm{C}-\mathrm{F}}=9.2 \mathrm{~Hz}\right)$, $29.6\left(\mathrm{~d},{ }^{2} \mathrm{~J}_{\mathrm{C}-\mathrm{F}}=28.2 \mathrm{~Hz}\right), 26.76 \mathrm{ppm}$.

${ }^{19}$ F NMR $\left(376 \mathrm{MHz}, \mathrm{CDCl}_{3}\right) \delta-103.4(\mathrm{~d}, \mathrm{~J}=14.6 \mathrm{~Hz}) \mathrm{ppm}$.

HRMS (ESI) m/z: [M+H] ${ }^{+}$calc'd. for $\mathrm{C}_{15} \mathrm{H}_{15} \mathrm{FNO}_{2}, 260.1087$; found 260.1191<smiles>CN1C(=O)c2ccccc2C12CC=CCC21C=CC=CC1</smiles>

1-methyl-8' $H$-spiro[indoline-3,5'-quinolin]-2-one (26): Prepared according to General Procedure A using $N$-(2-iodophenyl)- $N$-methylquinoline-5-carboxamide (S27) $(116 \mathrm{mg}, 0.3$ mmol, 1 equiv), DIPEA (160 $\mu \mathrm{L}, 0.9 \mathrm{mmol}, 3$ equiv) and 3DPAFIPN (10 mg, $5 \mathrm{~mol} \%)$. After 16 $\mathrm{h}$, the reaction was purified on silica (30-100\% EtOAc/hexanes) to provide the desired product as a yellow solid (74 $\mathrm{mg}, 94 \%$ yield).

${ }^{1} \mathbf{H}$ NMR $\left(400 \mathrm{MHz}, \mathrm{CDCl}_{3}\right) \delta 8.47(\mathrm{dd}, \mathrm{J}=4.7,1.7 \mathrm{~Hz}, 1 \mathrm{H}), 7.35(\mathrm{td}, \mathrm{J}=7.7,1.4 \mathrm{~Hz}, 1 \mathrm{H}), 7.07$ (td, J = 7.5, 1.0 Hz, 1H), $7.03-6.97(\mathrm{~m}, 2 \mathrm{H}), 6.95(\mathrm{dt}, \mathrm{J}=7.8,0.8 \mathrm{~Hz}, 1 \mathrm{H}), 6.87$ (dd, J = 7.9, 1.7 $\mathrm{Hz}, 1 \mathrm{H}), 6.37$ (ddd, J = 9.9, 4.1, 3.2 Hz, 1H), 5.54 (ddd, J = 9.9, 2.5, $1.8 \mathrm{~Hz}, 1 \mathrm{H}), 3.92$ (dt, J = $22.7,2.9 \mathrm{~Hz}, 1 \mathrm{H}), 3.74$ (ddd, J = 22.6, 4.0, $1.8 \mathrm{~Hz}, 1 \mathrm{H}), 3.28$ (s, 3H) ppm.

${ }^{13}$ C NMR $\left(126 \mathrm{MHz}, \mathrm{CDCl}_{3}\right) \delta 177.5,154.6,148.5,143.5,134.9,134.7,129.9,128.9,128.3$, $124.7,124.7,123.5,122.0,108.4,55.1,33.0,26.7 \mathrm{ppm}$.

HRMS (ESI) m/z: [M+H] calc'd. for $\mathrm{C}_{17} \mathrm{H}_{15} \mathrm{~N}_{2} \mathrm{O}$, 263.1184; found 263.1247 . 


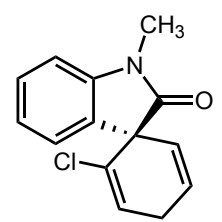

2-chloro-1'-methylspiro[cyclohexane-1,3'-indoline]-2,5-dien-2'-one (27): Prepared according to General Procedure A using 2-chloro- $N$-(2-iodophenyl)- $N$-methylbenzamide (S29) (186 mg, $0.5 \mathrm{mmol}, 1$ equiv), DIPEA (260 $\mu \mathrm{L}, 1.5 \mathrm{mmol}, 3$ equiv), and 3DPAFIPN (16 mg, $5 \mathrm{~mol} \%$ ). After $16 \mathrm{~h}$, the reaction was purified on silica (10-30\% EtOAc/hexanes) to provide the desired product as an off-white solid (86 $\mathrm{mg}, 70 \%$ yield).

${ }^{1}$ H NMR $\left(400 \mathrm{MHz}, \mathrm{CDCl}_{3}\right) \delta 7.32(\mathrm{t}, J=7.6 \mathrm{~Hz}, 1 \mathrm{H}), 7.14(\mathrm{~d}, J=8.1 \mathrm{~Hz}, 1 \mathrm{H}), 7.09(\mathrm{~d}, J=7.3$ $\mathrm{Hz}, 1 \mathrm{H}), 6.85(\mathrm{~d}, J=7.8 \mathrm{~Hz}, 1 \mathrm{H}), 6.23(\mathrm{t}, J=3.7 \mathrm{~Hz}, 1 \mathrm{H}), 6.04(\mathrm{dt}, J=9.8,3.4 \mathrm{~Hz}, 1 \mathrm{H}), 5.34$ $(\mathrm{dt}, J=9.8,2.1 \mathrm{~Hz}, 1 \mathrm{H}), 3.25(\mathrm{~s}, 3 \mathrm{H}), 3.16-3.05(\mathrm{~m}, 1 \mathrm{H}), 3.05-2.95(\mathrm{~m}, 1 \mathrm{H})$.

${ }^{13} \mathbf{C}$ NMR $\left(126 \mathrm{MHz}, \mathrm{CDCl}_{3}\right) \delta 175.4,143.7,131.6,129.1,128.0,126.3,125.5,124.3,124.2$, $123.1,108.2,56.7,28.3,26.71$.

HRMS (ESI) m/z: [M+H] ${ }^{+}$calc'd. for $\mathrm{C}_{14} \mathrm{H}_{13} \mathrm{ClNO}$, 246.0686; found 246.0675<smiles>CN1C(=O)C2(C=CCC(Cl)=C2)c2ccccc21</smiles>

3-chloro-1'-methylspiro[cyclohexane-1,3'-indoline]-2,5-dien-2'-one (28): Prepared according to General Procedure A using 3-chloro- $N$-(2-iodophenyl)- $N$-methylbenzamide (S31) (159 mg, $0.4 \mathrm{mmol}, 1$ equiv), DIPEA (210 $\mu \mathrm{L}, 1.2 \mathrm{mmol}, 3$ equiv), and 3DPAFIPN (14.0 $\mathrm{mg}, 5 \mathrm{~mol} \%$ ). After $16 \mathrm{~h}$, the reaction was purified on silica (10-20\% EtOAc/hexanes) to provide the desired product as light yellow solid (59.9 $\mathrm{mg}, 57 \%$ yield).

${ }^{1} \mathbf{H}$ NMR $\left(500 \mathrm{MHz}, \mathrm{CDCl}_{3}\right) \delta 7.31(\mathrm{tt}, J=7.7,1.3 \mathrm{~Hz}, 1 \mathrm{H}), 7.15-7.11(\mathrm{~m}, 1 \mathrm{H}), 7.08(\mathrm{tt}, J=$ $7.4,1.0 \mathrm{~Hz}, 1 \mathrm{H}), 6.88-6.82(\mathrm{~m}, 1 \mathrm{H}), 6.06(\mathrm{dtd}, J=9.8,3.5,1.0 \mathrm{~Hz}, 1 \mathrm{H}), 5.52$ (q, $J=1.7 \mathrm{~Hz}$, $1 \mathrm{H}), 5.40-5.35(\mathrm{~m}, 1 \mathrm{H}), 3.31-3.06(\mathrm{~m}, 5 \mathrm{H})$.

${ }^{13}$ C NMR $\left(126 \mathrm{MHz}, \mathrm{CDCl}_{3}\right) \delta 176.4,142.9,133.4,132.5,128.9,126.5,124.9,123.4,123.1$, 121.21, 121.20, 54.4, 33.2, 26.7.

HRMS (ESI) m/z: [M+H] $]^{+}$calc'd. for $\mathrm{C}_{14} \mathrm{H}_{13} \mathrm{ClNO}$, 246.0686; found 246.0770.<smiles>OC1C=CC2(C=C1)COc1cccnc12</smiles>

2'H-spiro[cyclohexane-1,3'-furo[3,2-b]pyridine]-2,5-dien-4-ol (29): Prepared according to General Procedure A using 2-bromo-3-((4-chlorobenzyl)oxy)pyridine (S32) (167 mg, $0.6 \mathrm{mmol}$, 1 equiv), DIPEA (315 $\mu \mathrm{L}, 1.8 \mathrm{mmol}, 3$ equiv) and 3DPAFIPN (19 mg, $5 \mathrm{~mol} \%)$. After $16 \mathrm{~h}$, the reaction was purified on silica $(100 \% \mathrm{EtOAc} /$ hexanes to $10 \% \mathrm{MeOH} / \mathrm{EtOAc})$ to provide the desired product as a 1.8: 1 mixture of diastereomers (combined yield $97 \mathrm{mg}, 85 \%$ yield). Major Diastereomer: 
${ }^{1} \mathbf{H}$ NMR $\left(600 \mathrm{MHz}, \mathrm{CDCl}_{3}\right) \delta 8.08(\mathrm{dd}, \mathrm{J}=4.8,1.3 \mathrm{~Hz}, 1 \mathrm{H}), 7.11(\mathrm{dd}, \mathrm{J}=8.1,1.4 \mathrm{~Hz}, 1 \mathrm{H}), 7.06$ (dd, J = 8.1, $4.8 \mathrm{~Hz}, 1 \mathrm{H}), 6.20$ (dd, J = 9.8, 4.2 Hz, 2H), $5.94(\mathrm{~d}, \mathrm{~J}=9.1 \mathrm{~Hz}, 2 \mathrm{H}), 4.54(\mathrm{~s}, 2 \mathrm{H})$, 4.50 (tt, J $=4.1,0.9 \mathrm{~Hz}, 1 \mathrm{H}) \mathrm{ppm}$.

${ }^{13}$ C NMR (151 MHz, $\left.\mathrm{CDCl}_{3}\right) \delta 153.7,152.1,142.6,131.5,130.2,123.3,117.4,81.7,60.9,49.0$ ppm.

HRMS (ESI) m/z: [M+H] calc'd for $\mathrm{C}_{12} \mathrm{H}_{13} \mathrm{NO}_{2}, 202.0868$, found 202.0874

Minor Diastereomer:

${ }^{1} \mathbf{H}$ NMR $\left(600 \mathrm{MHz}, \mathrm{CDCl}_{3}\right) \delta 8.06(\mathrm{dd}, J=4.8,1.3 \mathrm{~Hz}, 1 \mathrm{H}), 7.08(\mathrm{dd}, J=8.1,1.3 \mathrm{~Hz}, 1 \mathrm{H}), 7.03$ (dd, $J=8.1,4.8 \mathrm{~Hz}, 1 \mathrm{H}), 6.09$ (dd, $J=10.1,3.2 \mathrm{~Hz}, 2 \mathrm{H}), 5.88$ (dd, $J=10.0,1.5 \mathrm{~Hz}, 2 \mathrm{H}), 4.79$ (s, $1 \mathrm{H}), 4.47$ (s, 2H).

${ }^{13}$ C NMR (151 MHz, $\left.\mathrm{CDCl}_{3}\right) \delta 153.1,153.1,142.9,129.3,129.1,123.2,117.0,80.7,61.7,48.3$. HRMS (ESI) m/z: [M+H] calc'd for $\mathrm{C}_{12} \mathrm{H}_{12} \mathrm{NO}_{2}, 202.0868$, found 202.0929

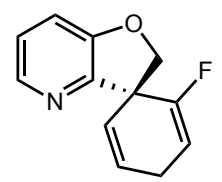

2-fluoro-2' $\boldsymbol{H}$-spiro[cyclohexane-1,3'-furo[3,2-b]pyridine]-2,5-diene (30): Prepared according to General Procedure A using 2-bromo-3-((2-fluorobenzyl)oxy)pyridine (S33) (144 mg, $0.5 \mathrm{mmol}, 1$ equiv), DIPEA (280 $\mu \mathrm{L}, 1.6 \mathrm{mmol}, 3$ equiv) and 3DPAFIPN (17 $\mathrm{mg}, 5 \mathrm{~mol} \%)$. After $16 \mathrm{~h}$, the reaction was purified on silica $(20-30 \%$ EtOAc/hexanes $)$ to provide the desired product as a yellow solid ( $86 \mathrm{mg}, 83 \%$ yield).

${ }^{1}$ H NMR $\left(600 \mathrm{MHz}, \mathrm{CDCl}_{3}\right) \delta 8.17(\mathrm{dd}, J=3.6,2.5 \mathrm{~Hz}, 1 \mathrm{H}), 7.11(\mathrm{~s}, 1 \mathrm{H}), 7.10(\mathrm{~d}, J=1.3 \mathrm{~Hz}$, $1 \mathrm{H}), 5.95$ (dddd, $J=10.7,4.5,3.4,1.2 \mathrm{~Hz}, 1 \mathrm{H}), 5.69$ (tt, $J=9.6,2.0 \mathrm{~Hz}, 1 \mathrm{H}), 5.54$ (dtd, $J=16.7$, 3.6, 1.2 Hz, 1H), 4.83 (d, $J=9.3 \mathrm{~Hz}, 1 \mathrm{H}), 4.45$ (d, $J=9.3 \mathrm{~Hz}, 1 \mathrm{H}), 3.09$ (ddtd, $J=22.8,5.4,3.5$, $2.0 \mathrm{~Hz}, 1 \mathrm{H}$ ), 2.91 (ddtd, $J=22.8,4.6,3.5,2.0 \mathrm{~Hz}, 1 \mathrm{H})$.

${ }^{13} \mathrm{C}$ NMR $\left(151 \mathrm{MHz}, \mathrm{CDCl}_{3}\right) \delta 156.2\left(\mathrm{~d},{ }^{1} J_{\mathrm{C}-F}=253.6 \mathrm{~Hz}\right), 153.6,151.3,142.8,127.1\left(\mathrm{~d},{ }^{3} J_{C-F}=\right.$ $5.8 \mathrm{~Hz}), 125.3\left(\mathrm{~d},{ }^{4} J_{C-F}=2.4 \mathrm{~Hz}\right), 123.5,116.8,102.5\left(\mathrm{~d},{ }^{2} J_{C-F}=16.5 \mathrm{~Hz}\right), 79.3,49.8\left(\mathrm{~d},{ }^{2} J_{C-F}=\right.$ $24.5 \mathrm{~Hz}), 26.4\left(\mathrm{~d},{ }^{3} J_{C-F}=6.7 \mathrm{~Hz}\right)$.

${ }^{19} \mathrm{~F}$ NMR $\left(565 \mathrm{MHz}, \mathrm{CDCl}_{3}\right) \delta-117.94--118.05(1 \mathrm{~F}, \mathrm{~m})$.

HRMS (ESI) m/z: [M+H] ${ }^{+}$calc'd. for $\mathrm{C}_{12} \mathrm{H}_{11} \mathrm{FNO}, 204.0825$; found 204.0956.

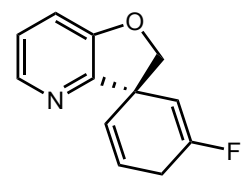

3-fluoro-2' $H$-spiro[cyclohexane-1,3'-furo[3,2-b]pyridine]-2,5-diene (31): Prepared according to General Procedure A using 2-bromo-3-((3-fluorobenzyl)oxy)pyridine (S34) (152 mg, $0.5 \mathrm{mmol}, 1$ equiv), DIPEA (300 $\mu \mathrm{L}, 1.7 \mathrm{mmol}, 3$ equiv) and 3DPAFIPN (17 $\mathrm{mg}, 5 \mathrm{~mol} \%)$. After $16 \mathrm{~h}$, the reaction was purified on silica $(20-30 \%$ EtOAc/hexanes) to provide the desired product as a colorless oil (91 $\mathrm{mg}, 83 \%$ yield).

${ }^{1}$ H NMR $\left(600 \mathrm{MHz}, \mathrm{CDCl}_{3}\right) \delta 8.14(\mathrm{dd}, J=4.6,1.6 \mathrm{~Hz}, 1 \mathrm{H}), 7.10(\mathrm{dd}, J=8.1,1.6 \mathrm{~Hz}, 1 \mathrm{H}), 7.07$ $(\mathrm{dd}, J=8.1,4.6 \mathrm{~Hz}, 1 \mathrm{H}), 5.89(\mathrm{ddt}, J=9.8,7.7,3.5 \mathrm{~Hz}, 2 \mathrm{H}), 5.73-5.69(\mathrm{~m}, 2 \mathrm{H}), 5.32(\mathrm{dq}, J=$ $16.3,1.5 \mathrm{~Hz}, 1 \mathrm{H}), 4.47(\mathrm{dd}, J=9.2,1.4 \mathrm{~Hz}, 1 \mathrm{H}), 4.44(\mathrm{dd}, J=9.2,0.7 \mathrm{~Hz}, 1 \mathrm{H}), 3.10$ (ddt, $J=$ 22.3, 3.1, 1.5 Hz, 2H), 2.92 (ddt, $J=22.3,3.4,2.1 \mathrm{~Hz}, 2 \mathrm{H}$ ). 
${ }^{13} \mathrm{C}$ NMR $\left(151 \mathrm{MHz}, \mathrm{CDCl}_{3}\right) \delta 158.8\left(\mathrm{~d},{ }^{1} J_{C-F}=258.2 \mathrm{~Hz}\right), 153.9\left(\mathrm{~d},{ }^{4} J_{C-F}=2.0 \mathrm{~Hz}\right), 152.5$, $142.9,127.4\left(\mathrm{~d},{ }^{3} J_{C-F}=2.8 \mathrm{~Hz}\right), 123.2,123.2,123.1,116.9,104.0\left(\mathrm{~d},{ }^{2} J_{C-F}=16.7 \mathrm{~Hz}\right), 82.4(\mathrm{~d}$, $\left.{ }^{4} J_{C-F}=2.8 \mathrm{~Hz}\right), 50.0\left(\mathrm{~d},{ }^{3} J_{C-F}=8.1 \mathrm{~Hz}\right), 26.8\left(\mathrm{~d},{ }^{2} J_{C-F}=26.1 \mathrm{~Hz}\right)$.

${ }^{19}$ F NMR $\left(565 \mathrm{MHz}, \mathrm{CDCl}_{3}\right) \delta-103.27(\mathrm{dd}, J=16.9,7.8 \mathrm{~Hz})$.

HRMS (ESI) m/z: [M+H] ${ }^{+}$calc'd. for $\mathrm{C}_{12} \mathrm{H}_{11} \mathrm{FNO}$, 204.0825; found 204.1005.

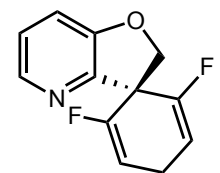

2,6-difluoro-2' $H$-spiro[cyclohexane-1,3'-furo[3,2-b]pyridine]-2,5-diene (32): Prepared according to General Procedure A using 2-bromo-3-((2,6-difluorobenzyl)oxy)pyridine (S35) (175 mg, $0.6 \mathrm{mmol}, 1$ equiv), DIPEA (300 $\mu \mathrm{L}, 1.5 \mathrm{mmol}, 3$ equiv) and 3DPAFIPN (16 $\mathrm{mg}, 4 \mathrm{~mol} \%)$. After $16 \mathrm{~h}$, the reaction was purified on silica $(10-30 \%$ EtOAc/hexanes $)$ to provide the desired product as a light yellow solid ( $83 \mathrm{mg}, 64 \%$ yield).

${ }^{1}$ H NMR $\left(600 \mathrm{MHz}, \mathrm{CDCl}_{3}\right) \delta 8.20(\mathrm{dd}, J=4.4,1.7 \mathrm{~Hz}, 1 \mathrm{H}), 7.16(\mathrm{dd}, J=8.2,4.4 \mathrm{~Hz}, 1 \mathrm{H}), 7.14$ $(\mathrm{dd}, J=8.2,1.7 \mathrm{~Hz}, 1 \mathrm{H}), 5.58(\mathrm{ddt}, J=10.4,5.3,3.7 \mathrm{~Hz}, 2 \mathrm{H}), 4.80(\mathrm{~s}, 2 \mathrm{H}), 3.07$ (dtt, $J=22.2$, $5.1,3.7 \mathrm{~Hz}, 1 \mathrm{H}), 2.89$ (dtt, $J=22.3,4.9,3.7 \mathrm{~Hz}, 1 \mathrm{H})$.

${ }^{13} \mathrm{C}$ NMR $\left(151 \mathrm{MHz}, \mathrm{CDCl}_{3}\right) \delta 154.4\left(\mathrm{dd},{ }^{1} J_{C-F}=254.8,{ }^{3} J_{C-F}=12.1 \mathrm{~Hz}\right), 154.6,147.7,142.8$, $124.2,117.0,102.3\left(\mathrm{~d},{ }^{2} J_{C-F}=14.4 \mathrm{~Hz}\right), 75.5,52.1\left(\mathrm{t},{ }^{2} J_{C-F}=27.8 \mathrm{~Hz}\right), 22.2\left(\mathrm{t},{ }^{3} J_{C-F}=8.0 \mathrm{~Hz}\right)$. ${ }^{19}$ F NMR $\left(565 \mathrm{MHz}, \mathrm{CDCl}_{3}\right) \delta-119.83(\mathrm{dq}, J=10.2,5.1 \mathrm{~Hz})$.

HRMS (ESI) m/z: [M+H] $]^{+}$calc'd. for $\mathrm{C}_{12} \mathrm{H}_{10} \mathrm{~F}_{2} \mathrm{NO}, 222.0730$; found 222.0972<smiles>[Y6]N(Cc1ccc(C(=O)O)cc1)c1ccccc1I</smiles>

4-(( $N$-(2-iodophenyl)methylsulfonamido)methyl)benzoic acid (33)

A $100 \mathrm{~mL}$ round bottom flask was charged with $N$-(2-iodophenyl)methanesulfonamide (S1), (414 mg, $1.4 \mathrm{mmol}, 1.0$ equiv) and $\mathrm{K}_{2} \mathrm{CO}_{3}$ (480 mg, $3.5 \mathrm{mmol}, 2.2$ equiv). DMF was added (50 $\mathrm{mL})$, followed by benzyl bromide $(350 \mu \mathrm{L}, 2.4 \mathrm{mmol}, 2.3$ equiv). The reaction was stirred overnight (ca. $16 \mathrm{~h}$ ) at $50^{\circ} \mathrm{C}$. The reaction was cooled to room temperature and then partitioned between EtOAc and water. The organic layer was washed with brine 3x, dried with $\mathrm{MgSO}_{4}$ and concentrated. The crude oil was dissolved in $\mathrm{THF} / \mathrm{H}_{2} \mathrm{O}(1: 1 \mathrm{v} / \mathrm{v})$ and lithium hydroxide (excess, ca 10 equiv) was added. The reaction was stirred at $50{ }^{\circ} \mathrm{C}$ until reaction completion as determined by TLC. The reaction was then cooled to room temperature and partitioned between EtOAc and water. The organic layer was washed $3 \mathrm{x}$ with $1 \mathrm{M} \mathrm{NaOH}$. The organic layer was then discarded. EtOAc was added and the aqueous layer was re-acidified with $\mathrm{HCl}$. The aqueous layer was extracted $3 x$ wth EtOAc. The combined organic layers were dried with $\mathrm{Na}_{2} \mathrm{SO}_{4}$ and concentrated. The desired product was purified by trituration with a minimal amount of EtOAc and was collected by filtration as a white solid (371 $\mathrm{mg}, 62 \%$ over 2 steps).

${ }^{1}$ H NMR $\left(400 \mathrm{MHz}, \mathrm{CDCl}_{3}\right) \delta 8.04(\mathrm{~d}, J=8.3 \mathrm{~Hz}, 1 \mathrm{H}), 7.94(\mathrm{dd}, J=7.9,1.5 \mathrm{~Hz}, 1 \mathrm{H}), 7.40(\mathrm{~d}, J$ $=8.3 \mathrm{~Hz}, 2 \mathrm{H}), 7.26(\mathrm{dd}, J=7.4,1.4 \mathrm{~Hz}, 1 \mathrm{H}), 7.09(\mathrm{dd}, J=8.0,1.6 \mathrm{~Hz}, 1 \mathrm{H}), 7.05(\mathrm{td}, J=7.5,1.6$ $\mathrm{Hz}, 1 \mathrm{H}), 5.16(\mathrm{~d}, J=14.9 \mathrm{~Hz}, 1 \mathrm{H}), 4.66(\mathrm{~d}, J=14.9 \mathrm{~Hz}, 1 \mathrm{H}), 3.13(\mathrm{~s}, 3 \mathrm{H})$.

${ }^{13}$ C NMR $\left(101 \mathrm{MHz}, \mathrm{CDCl}_{3}\right) \delta 171.2,141.6,140.6,140.2,134.3,130.4,129.7,129.2,129.0$, $126.6,101.8,55.2,40.4$.

LRMS (APCI) m/z: $[\mathrm{M}+\mathrm{H}]^{+}$calc'd. for $\mathrm{C}_{15} \mathrm{H}_{15} \mathrm{INO}_{4} \mathrm{~S} 432.0$, found 431.6 . 


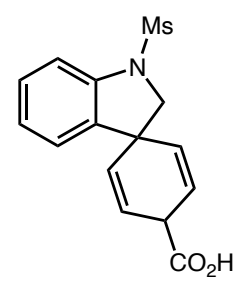

1'-(methylsulfonyl)spiro[cyclohexane-1,3'-indoline]-2,5-diene-4-carboxylic acid (34)

Prepared according to General Procedure A using 4-(( $N$-(2-iodophenyl) methylsulfonamido) methyl) benzoic acid 33 (120 mg, 0.28 mmol, 1.0 equiv), DIPEA ( $244 \mu \mathrm{L}, 1.4$ mmol, 5.0 equiv) and 3DPAFIPN (10.1 mg, $5 \mathrm{~mol} \%)$. After $16 \mathrm{~h}$, the reaction mixture was partitioned between EtOAc and water. The aqueous layer was acidified with $1 \mathrm{~N} \mathrm{HCl}$ and extracted $5 \mathrm{x}$. The combined organic layers were washed with brine, dried with $\mathrm{Na}_{2} \mathrm{SO}_{4}$, filtered, and concentrated. ${ }^{1} \mathrm{H} \mathrm{NMR}$ analysis of the crude reaction mixture indicated a 1:1 diastereomeric ratio. Purification of the residue by silica gel chromatography (EtOAc (containing 1\% v/v AcOH):Hex, 30-100\% gradient) afforded three fractions: the leading fraction contained a single diastereomer (f1: 30.8 $\mathrm{mg}$ ), followed by two fractions that were enriched in either diastereomer (f2: $176.9 \mathrm{mg}, 1.6: 1 \mathrm{dr}$; f3 $210.7 \mathrm{mg}, 1: 2 \mathrm{dr}$ ), combined yield: $418.4 \mathrm{mg}$ (95\%).

Diastereomer 1 (f1):

${ }^{1} \mathbf{H}$ NMR $\left(400 \mathrm{MHz}, \mathrm{CDCl}_{3}\right) \delta 6.04(\mathrm{dd}, J=10.1,3.6 \mathrm{~Hz}, 1 \mathrm{H}), 5.91(\mathrm{dd}, J=10.2,2.1 \mathrm{~Hz}, 1 \mathrm{H})$, $3.89(\mathrm{~m}, 1 \mathrm{H}), 3.87(\mathrm{~s}, 2 \mathrm{H}), 2.95(\mathrm{~s}, 3 \mathrm{H})$.

${ }^{13} \mathrm{C}$ NMR $\left(151 \mathrm{MHz}, \mathrm{CDCl}_{3}\right) \delta 177.2,141.1,136.2,130.9,129.1,125.8,124.4,121.7,113.3$, $62.3,45.3,41.8,34.7$.

Diastereomer 2 (characteristic peaks):

${ }^{1}$ H NMR $\left(400 \mathrm{MHz}, \mathrm{CDCl}_{3}\right) \delta 6.08(\mathrm{dd}, J=10.1,3.4 \mathrm{~Hz}, 1 \mathrm{H}), 5.92(\mathrm{dd}, J=10.1,2.2 \mathrm{~Hz}, 1 \mathrm{H})$, $3.95-3.91(\mathrm{~m}, 1 \mathrm{H})$

For the mixture of diastereomers (f2)

${ }^{13}$ C NMR $\left(151 \mathrm{MHz}, \mathrm{CDCl}_{3}\right) \delta 177.9,176.3,141.9,136.4,136.2,131.0,130.9,129.2,129.1$, $125.8,125.3,124.4,124.2,122.5,121.7,113.5,113.3,62.3,62.3,45.3,42.4,41.5,35.9,34.7$, 32.6 .

LRMS (APCI) m/z: [M-H]' calc'd for $\mathrm{C}_{15} \mathrm{H}_{14} \mathrm{NO}_{4} \mathrm{~S}$ 304.1, found 304.1

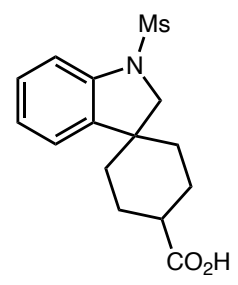

\section{1'-(methylsulfonyl)spiro[cyclohexane-1,3'-indoline]-4-carboxylic acid (S36)}

A $4 \mathrm{~mL}$ vial was charged with 1'-(methylsulfonyl)spiro[cyclohexane-1,3'-indoline]-2,5-diene-4carboxylic acid (S37, from f2 (1.6:1 dr; $15.4 \mathrm{mg}, 0.05 \mathrm{mmol}), 5 \mathrm{mg} \mathrm{5 \%} \mathrm{Pd/C} \mathrm{(wet} \mathrm{basis),} \mathrm{and} \mathrm{a}$ stir bar. To the vial was added $2 \mathrm{~mL}$ of 200 proof ethanol and the vial was placed in Parr highpressure reactor. The reactor was sealed, evacuated, and backfilled with hydrogen at 1 PSI. This was repeated for a total of 5 times. The reactor was then pressurized to 40 PSI with hydrogen and 
stirred for 72 hours. Upon reaction completion, the reactor was depressurized and dismantled. $0.5 \mathrm{~mL}$ of water was added to the reaction vial then the reaction mixture was filtered through celite. The filtrate was concentrated then azeotroped with $10 \mathrm{~mL}$ of $\mathrm{MeCN}$ to remove the remaining water. Quantitative conversion to the hydrogenated product was detected by ${ }^{1} \mathrm{H}$ NMR and LRMS. The crude residue was used in the next step without further purification.

LRMS (APCI) m/z: [M-H]' calc'd for $\mathrm{C}_{15} \mathrm{H}_{18} \mathrm{NO}_{4} \mathrm{~S}$ 308.1, found 308.1

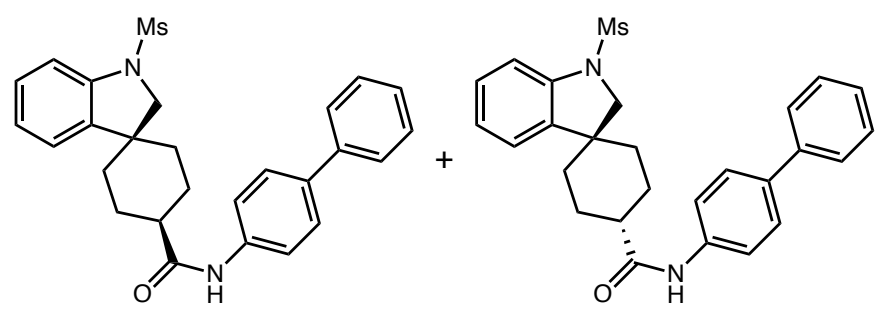

$N$-([1,1'-biphenyl]-4-yl)-1'-(methylsulfonyl)spiro[cyclohexane-1,3'-indoline]-4-carboxamide (35)

In an $8 \mathrm{~mL}$ reaction tube equipped with a stir bar, 1'-(methylsulfonyl)spiro[cyclohexane-1,3'indoline]-4-carboxylic acid (35) (15.4 $\mathrm{mg}, 0.05 \mathrm{mmol}, 1.0$ equiv) was dissolved in EtOAc to make a $0.1 \mathrm{M}$ solution. 4-aminobiphenyl $10 \mathrm{mg}, 0.06 \mathrm{mmol}, 1.2$ equiv) was added, followed by DIPEA $35 \mu \mathrm{L}, 0.2 \mathrm{mmol}, 4.0$ equiv). Propanephosphonic acid anhydride (as a 50\% w/w solution in EtOAc) $55 \mu \mathrm{L}, 0.08 \mathrm{mmol}, 1.6$ equiv) was then added in one portion. The reaction mixture was allowed to stir for $3 \mathrm{~h}$ before being partitioned between water and EtOAc. The organic layer was washed with $1 \mathrm{M} \mathrm{HCl} 3 \mathrm{x}$ then brine $3 \mathrm{x}$. The organic layer was then dried with $\mathrm{Na}_{2} \mathrm{SO}_{4}$, filtered, and concentrated. The crude residue was purified by preparatory TLC in $50 \%$ EtOAc/Hex eluent to separate both diastereomers and afford the desired products as white solids: diasteromer $1\left(\mathrm{R}_{\mathrm{f}} 0.47,50 \%\right.$ EtOAc/Hex $): 12.0 \mathrm{mg}$; diastereomer $2\left(\mathrm{R}_{\mathrm{f}} 0.35,50 \% \mathrm{EtOAc} / \mathrm{Hex}\right)$ : $5.8 \mathrm{mg}$; Combined yield: $17.8 \mathrm{mg}, 82 \%$ over 2 -steps).

Diastereomer $1\left(\mathrm{R}_{\mathrm{f}} 0.47\right)$ :

${ }^{1} \mathbf{H}$ NMR $\left(600 \mathrm{MHz}, \mathrm{CDCl}_{3}\right) \delta 7.61(\mathrm{~d}, J=8.5 \mathrm{~Hz}, 2 \mathrm{H}), 7.57(\mathrm{~d}, J=8.3 \mathrm{~Hz}, 4 \mathrm{H}), 7.46-7.39(\mathrm{~m}$, $3 \mathrm{H}), 7.37-7.31(\mathrm{~m}, 1 \mathrm{H}), 7.27-7.21(\mathrm{~m}, 2 \mathrm{H}), 7.15(\mathrm{~d}, J=7.6 \mathrm{~Hz}, 1 \mathrm{H}), 7.07(\mathrm{t}, J=7.5 \mathrm{~Hz}, 1 \mathrm{H})$, $3.87(\mathrm{~s}, 2 \mathrm{H}), 2.92(\mathrm{~s}, 3 \mathrm{H}), 2.43-2.32(\mathrm{~m}, 1 \mathrm{H}), 2.08(\mathrm{~d}, J=11.4 \mathrm{~Hz}, 2 \mathrm{H}), 1.91(\mathrm{~d}, J=11.0 \mathrm{~Hz}$, $2 \mathrm{H}), 1.83-1.71(\mathrm{~m}, 4 \mathrm{H})$.

${ }^{13}$ C NMR $\left(151 \mathrm{MHz}, \mathrm{CDCl}_{3}\right) \delta 173.0,141.4,140.5,139.0,137.8,137.1,129.3,128.3,127.7$, 127.2, 126.9, 123.7, 122.9, 120.7, 115.5, 58.4, 45.8, 44.8, 43.9, 35.9, 34.7, 29.7, 26.2.

HRMS (ESI) m/z: [M+H] $]^{+}$calc'd. for $\mathrm{C}_{27} \mathrm{H}_{29} \mathrm{~N}_{2} \mathrm{O}_{3} \mathrm{~S}$, 461.1821, found 461.1875

Diastereomer $2\left(\mathrm{R}_{\mathrm{f}} 0.35\right)$ :

${ }^{1}$ H NMR $\left(600 \mathrm{MHz}, \mathrm{CDCl}_{3}\right) \delta 7.63(\mathrm{~d}, J=8.6 \mathrm{~Hz}, 2 \mathrm{H}), 7.61-7.56(\mathrm{~m}, 4 \mathrm{H}), 7.48-7.38(\mathrm{~m}$, $4 \mathrm{H}), 7.36-7.31(\mathrm{~m}, 1 \mathrm{H}), 7.29(\mathrm{~s}, 1 \mathrm{H}), 7.23(\mathrm{ddd}, J=8.1,7.5,1.3 \mathrm{~Hz}, 1 \mathrm{H}), 7.06(\mathrm{td}, J=7.5,1.1$ $\mathrm{Hz}, 1 \mathrm{H}), 3.76(\mathrm{~s}, 2 \mathrm{H}), 2.91(\mathrm{~s}, 3 \mathrm{H}), 2.62-2.52(\mathrm{~m}, 1 \mathrm{H}), 2.25-2.12(\mathrm{~m}, 4 \mathrm{H}), 1.94-1.86(\mathrm{~m}$, $2 \mathrm{H}), 1.69-1.62(\mathrm{~m}, 2 \mathrm{H})$.

${ }^{13}$ C NMR $\left(151 \mathrm{MHz}, \mathrm{CDCl}_{3}\right) \delta 173.1,141.1,140.5,139.1,137.7,137.1,128.8,128.5,127.7$, 127.2, 126.9, 124.9, 123.7, 120.1, 115.3, 61.7, 45.8, 43.3, 42.1, 34.3, 34.1, 30.2, 25.8.

HRMS (ESI) m/z: [M+H] $]^{+}$calc'd. for $\mathrm{C}_{27} \mathrm{H}_{29} \mathrm{~N}_{2} \mathrm{O}_{3} \mathrm{~S}$, 461.1821, found 461.1874 . 


\section{Computational Details}

All DFT calculations were carried out using the Gaussian 16 software package ${ }^{11}$ at the uM06 ${ }^{12}$ level of theory with the $6-311+\mathrm{G}(\mathrm{d}, \mathrm{p})^{13}$ basis set. The CPCM formalism for the Self Consistent Reaction Field (SCRF) model of solvation was employed in calculations to account for solvation in $\mathrm{MeCN}$, and the default parameters as implemented in Gaussian were used. NBO charges were obtained using NBO Version 3.1 in Gaussian 16. ${ }^{14}$ Orbitals were visualized using Avagadro version 1.2.0 $0^{15}$ or GaussView $6 .{ }^{11}$

Reduction potentials were calculated using a modified procedure as described by Nicewicz and coworkers. ${ }^{16}$ Geometry optimizations were carried out for the reduced and neutral forms of each molecule, and frequency calculations were performed on the minimized structures to ensure no imaginary frequencies existed. Gibbs free energies $\left(\mathrm{G}_{298}\right)$ were obtained from the calculation and employed in the following equation:

$$
E_{1 / 2}^{0, \text { calc }}=-\frac{\left(G_{298}[\text { reduced }]-G_{298}[\text { oxidized }]\right)}{n_{e} \mathcal{F}}-E_{1 / 2}^{0, S H E}+E_{1 / 2}^{0, S C E}
$$

Where $n_{e}$ is the number of electrons transferred $\left(n_{e}=1\right.$ for all calculations here), $\mathcal{F}$ is the Faraday constant (value $23.061 \mathrm{kcal} \mathrm{mol}^{-1} \mathrm{~V}^{-1}$ ), $E_{1 / 2}^{0, S H E}$ is the absolute value for the standard hydrogen electrode $\left(\mathrm{SHE}\right.$, value $=4.281 \mathrm{~V}$ ) and $E_{1 / 2}^{0, S C E}$ is the potential of the saturated calomel electrode $(\mathrm{SCE})$ relative to the $\mathrm{SHE}$ in $\mathrm{MeCN}$ (value $=-0.141 \mathrm{~V}$ ) ${ }^{17}$, and $\mathrm{G}_{298}$ [oxidized] and $\mathrm{G}_{298}$ [reduced] are the Gibbs free energies in DMSO obtained from DFT calculations.

NBO coefficients for the cyclohexadienyl anion shown in Figure 3 are shown below. These values suggest that the diallyl anion is the dominant resonance contributor.

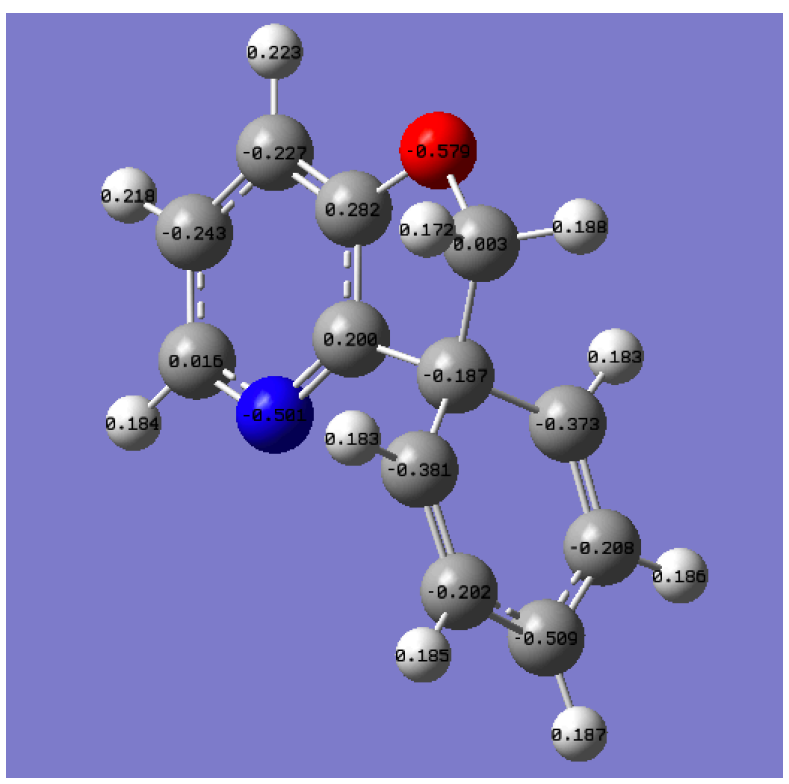


Molecular coordinates of optimized structures:

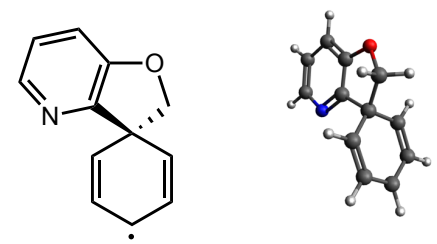

Charge: 0

Multiplicity: 2

Number of Imaginary Frequencies: 0

Solvation: $\mathrm{MeCN}$

$\mathrm{G}_{298}$ : -592.774968 Hartree

$\begin{array}{llll}\mathrm{C} & 2.1359520 & -1.8896820 & -0.0496070 \\ \mathrm{C} & 3.1861070 & -0.9987020 & 0.1321480 \\ \mathrm{C} & 2.9431520 & 0.3713730 & 0.1841100 \\ \mathrm{C} & 1.6254950 & 0.7551680 & 0.0419870 \\ \mathrm{C} & 0.6391270 & -0.2082310 & -0.1308360 \\ \mathrm{~N} & 0.8577230 & -1.5059140 & -0.1734550 \\ \mathrm{H} & 3.7393170 & 1.0946780 & 0.3238200 \\ \mathrm{H} & 2.3295360 & -2.9585960 & -0.0925660 \\ \mathrm{H} & 4.1976640 & -1.3776000 & 0.2302670 \\ \mathrm{O} & 1.1400950 & 2.0143860 & 0.0668640 \\ \mathrm{C} & -0.2220040 & 1.9418370 & -0.4049320 \\ \mathrm{H} & -0.2233980 & 2.1681040 & -1.4787000 \\ \mathrm{H} & -0.8062050 & 2.6922400 & 0.1295300 \\ \mathrm{C} & -0.7197230 & 0.4922050 & -0.1623780 \\ \mathrm{C} & -1.5940820 & -0.0037460 & -1.2661860 \\ \mathrm{C} & -1.3538670 & 0.3427030 & 1.1893470 \\ \mathrm{C} & -2.7817220 & -0.6228760 & -1.0343270 \\ \mathrm{H} & -1.2186370 & 0.1187960 & -2.2800550 \\ \mathrm{C} & -2.5460480 & -0.2838250 & 1.3700900 \\ \mathrm{H} & -0.7962480 & 0.7415160 & 2.0352210 \\ \mathrm{C} & -3.2796340 & -0.7941480 & 0.2761670 \\ \mathrm{H} & -3.3647350 & -0.9882490 & -1.8752470 \\ \mathrm{H} & -2.9500320 & -0.3834420 & 2.3738660 \\ \mathrm{H} & -4.2286040 & -1.2935920 & 0.4396380\end{array}$




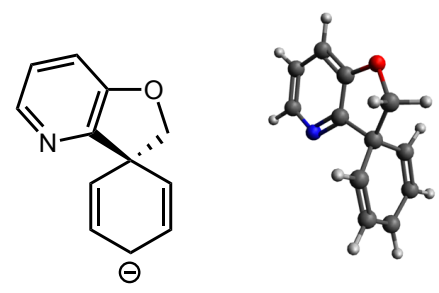

Charge: -1

Multiplicity: 1

Number of Imaginary Frequencies: 0

Solvation: MeCN

$\mathrm{G}_{298}$ : -592.888245 Hartree

$\begin{array}{llll}\mathrm{C} & 2.076487 & -1.923675 & -0.112260 \\ \mathrm{C} & 3.153155 & -1.081021 & 0.121502 \\ \mathrm{C} & 2.951311 & 0.296572 & 0.212533 \\ \mathrm{C} & 1.650719 & 0.725897 & 0.059913 \\ \mathrm{C} & 0.621043 & -0.189039 & -0.156695 \\ \mathrm{~N} & 0.812151 & -1.493178 & -0.247670 \\ \mathrm{H} & 3.769359 & 0.989395 & 0.383874 \\ \mathrm{H} & 2.235740 & -2.997189 & -0.193741 \\ \mathrm{H} & 4.149697 & -1.497808 & 0.224187 \\ \mathrm{O} & 1.220503 & 2.653200 & 0.102935 \\ \mathrm{C} & -0.155812 & 1.989316 & -0.358778 \\ \mathrm{H} & -0.152963 & 2.265084 & -1.423647 \\ \mathrm{H} & -0.708878 & 2.739142 & 0.211695 \\ \mathrm{C} & -0.710632 & 0.558718 & -0.164365 \\ \mathrm{C} & -1.671897 & 0.164641 & -1.256064 \\ \mathrm{C} & -1.383810 & 0.481000 & 1.186441 \\ \mathrm{C} & -2.795092 & -0.578860 & -1.972200 \\ \mathrm{H} & -1.389390 & 0.419182 & -2.278172 \\ \mathrm{C} & -2.512029 & -0.354137 & 1.356645 \\ \mathrm{H} & -0.879557 & 0.854767 & 2.040930 \\ \mathrm{C} & -3.227819 & -0.932789 & 0.286072 \\ \mathrm{H} & -3.399656 & -0.881098 & -1.867266 \\ \mathrm{H} & -2.895207 & -0.471807 & 2.372384 \\ \mathrm{H} & -4.151973 & -1.478266 & 0.448639\end{array}$




\section{References}

1. Pearson, R. M.; Lim, C.-H.; McCarthy, B. G.; Musgrave, C. B.; Miyake, G. M. Organocatalyzed Atom Transfer Radical Polymerization Using N-Aryl Phenoxazines as Photoredox Catalysts. J. Am. Chem. Soc. 2016, 138 (35), 11399-11407

2. Speckmeier, E.; Fischer, T.; Zeitler, K. A Toolbox Approach to Construct Broadly Applicable Metal-Free Catalysts for Photoredox Chemistry: Deliberate Tuning of Redox Potentials and Importance of Halogens in Donor-Acceptor Cyanoarenes. J. Am. Chem. Soc. 2018, 140 (45), 15354-15365.

3. Fernández, A.; Varela, J.; Saá, C. Formation of Indoles, Dihydroisoquinolines, and Dihydroquinolines by Ruthenium-catalyzed Heterocyclizations. Synthesis, 2012, 44, 3285-3295

4. Zhang, Z.; Liu, Y-H.; Zhang.X.; Wang, X-C. KMnO4-Mediated oxidative C-N bond cleavage of tertiary amines: synthesis of amides and sulfonamides. Tetrahedron, 2019, 75, 2763-2770

5. Colobert, F; Valdivia, V.; Choppin, S.; Leroux, F.; Fernández, I.; Álvarez, E.; Khiar, N. Axial chirality control during Suzuki-Miyaura cross-coupling reactions: the tertbutylsulfinyl group as an efficient chiral auxiliary. Org. Lett. 2009, 11(25), 5130-5133

6. Hu, Q.; Kunde, J.; Hanke, N; Hartmann, R. Identification of 4-(4-nitro-2phenethoxyphenyl)pyridine as a promising new lead for discovering inhibitors of both human and rat 11ß-hydroxylase. Eur. J. Med. Chem. 2015, 96, 139-150

7. Zheng, N.; Anderson, K.; Huang, X.; Nguyen, H.; Buchwald, S. A palladium-catalyzed regiospecific synthesis of N-aryl benzimidazoles. Angew. Chem. Int. Ed. 2007, 40, 75097512

8. Palmerinin, C.; Tartacca, F.; Mazzoni, M.; Granieri, L.; Goracci, L.; Scrascia, A.; Lepri, $\mathrm{S}$. Synthesis of new indole-based bisphosphonates and evaluation of their chelating ability in PE/CA-PJ15 cells. Eur. J. Med. Chem. 2015, 102, 403-442

9. Fan, J.; Yao, Q-J.; Liu, Y-H.; Liao, G.; Zhang, S.; Shi, B-F. Asymmetric total synthesis of TAN-1085 facilitated by Pd-catalyzed atroposelective C-H olefination. Org. Lett. 2019, 21(9), 3352-3356

10. Rousseau, G.; Robert, F.; Schenk, K.; Landais, Y. Org. Lett. 2008, 10, 20, 4441-4444

11. Frisch, M. J.; Trucks, G. W.; Schlegel, H. B.; Scuseria, G. E.; Robb, M. A.; Cheeseman, J. R.; Scalmani, G.; Barone, V.; Petersson, G. A.; Nakatsuji, H.; Li, X.; Caricato, M.; Marenich, A. V.; Bloino, J.; Janesko, B. G.; Gomperts, R.; Mennucci, B.; Hratchian, H. P.; Ortiz, J. V.; Izmaylov, A. F.; Sonnenberg, J. L.; Williams-Young, D.; Ding, F.; Lipparini, F.; Egidi, F.; Goings, J.; Peng, B.; Petrone, A.; Henderson, T.; Ranasinghe, D.; Zakrzewski, V. G.; Gao, J.; Rega, N.; Zheng, G.; Liang, W.; Hada, M.; Ehara, M.; Toyota, K.; Fukuda, R.; Hasegawa, J.; Ishida, M.; Nakajima, T.; Honda, Y.; Kitao, O.; Nakai, H.; Vreven, T.; Throssell, K.; Montgomery, J. A., Jr.; Peralta, J. E.; Ogliaro, F.; Bearpark, M. J.; Heyd, J. J.; Brothers, E. N.; Kudin, K. N.; Staroverov, V. N.; Keith, T. A.; Kobayashi, R.; Normand, J.; Raghavachari, K.; Rendell, A. P.; Burant, J. C.; Iyengar, S. S.; Tomasi, J.; Cossi, M.; Millam, J. M.; Klene, M.; Adamo, C.; Cammi, R.; Ochterski, J. W.; Martin, R. L.; Morokuma, K.; Farkas, O.; Foresman, J. B.; Fox, D. J. Gaussian Inc 16, Revision B.01. Gaussian Inc., Wallingford CT. 2016. 
12. Zhao, Y.; Truhlar, D. G. The M06 Suite of Density Functionals for Main Group Thermochemistry, Thermochemical Kinetics, Noncovalent Interactions, Excited States, and Transition Elements: Two New Functionals and Systematic Testing of Four M06Class Functionals and 12 Other Function. Theor. Chem. Acc. 2008, 120 (1), 215- 241.

13. McLean, A. D.; Chandler, G. S. Contracted Gaussian Basis Sets for Molecular Calculations. I. Second Row Atoms, $Z=11-18$. J. Chem. Phys. 1980, 72 (10), 5639- 5648

14. NBO Version 3.1, Glendening, E. D.; Reed, A. E.; Carpenter, J. E.; Weinhold, F.

15. Marcus D Hanwell, Donald E Curtis, David C Lonie, Tim Vandermeersch, Eva Zurek and Geoffrey R Hutchison; "Avogadro: An advanced semantic chemical editor, visualization, and analysis platform" Journal of Cheminformatics 2012, 4:17.

16. Roth, H. G.; Romero, N. A.; Nicewicz, D. A. Experimental and Calculated Electrochemical Potentials of Common Organic Molecules for Applications to SingleElectron Redox Chemistry. Synlett 2016, 27 (05), 714-723.

17. Isse, A. A.; Gennaro, A. Absolute Potential of the Standard Hydrogen Electrode and the Problem of Interconversion of Potentials in Different Solvents. J. Phys. Chem. B 2010, 114 (23), 7894-7899. 


\section{NMR Spectra}
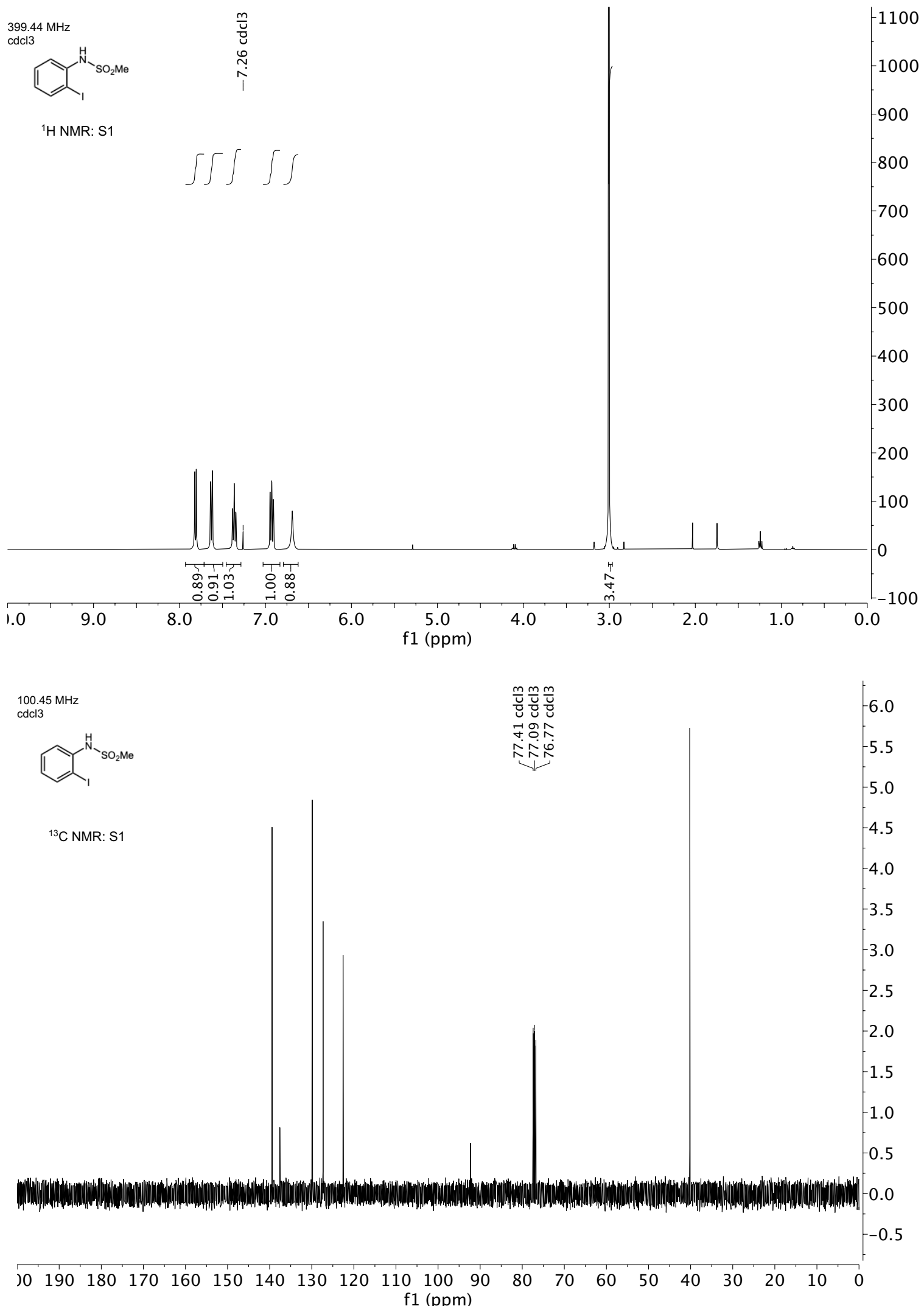

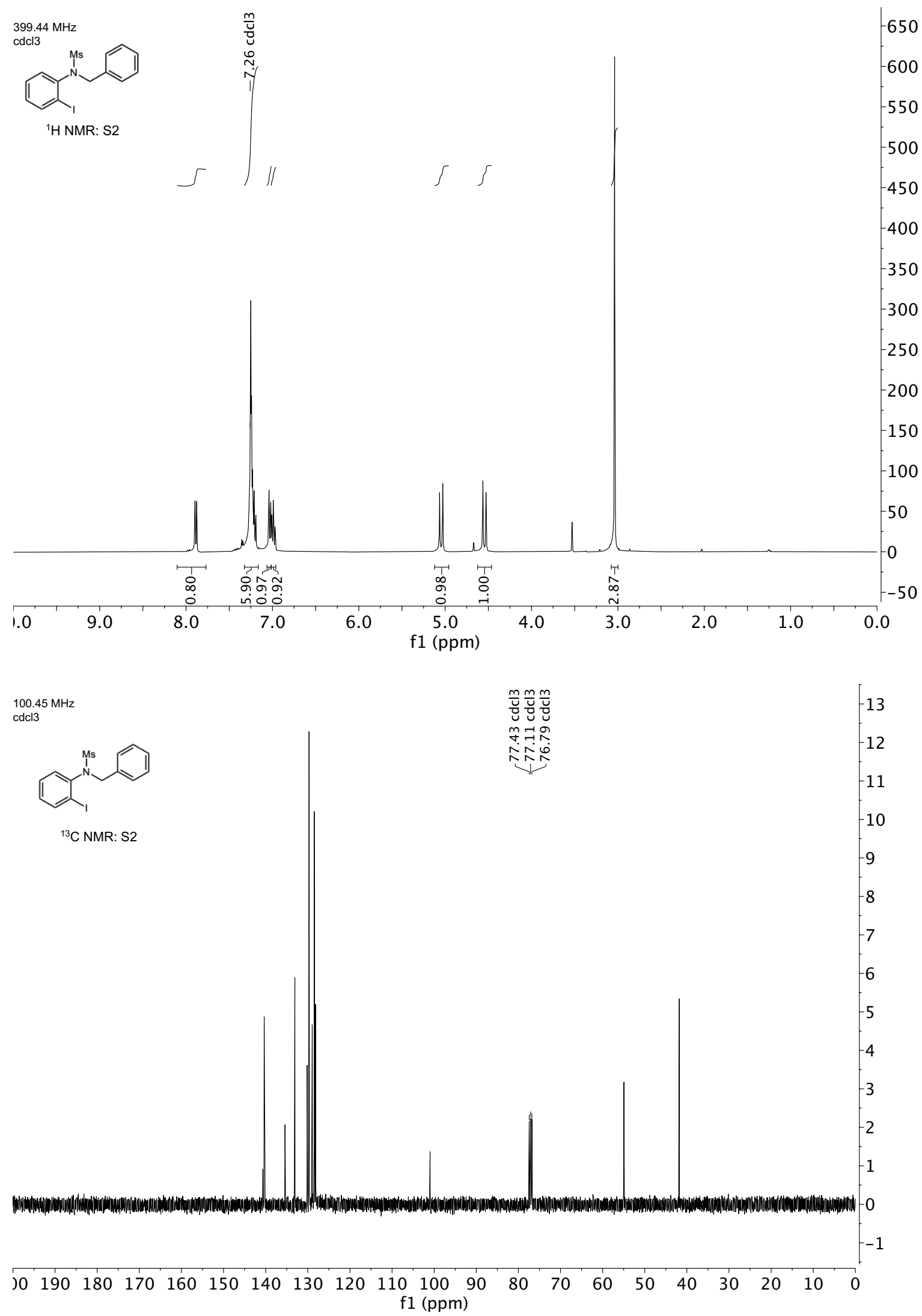


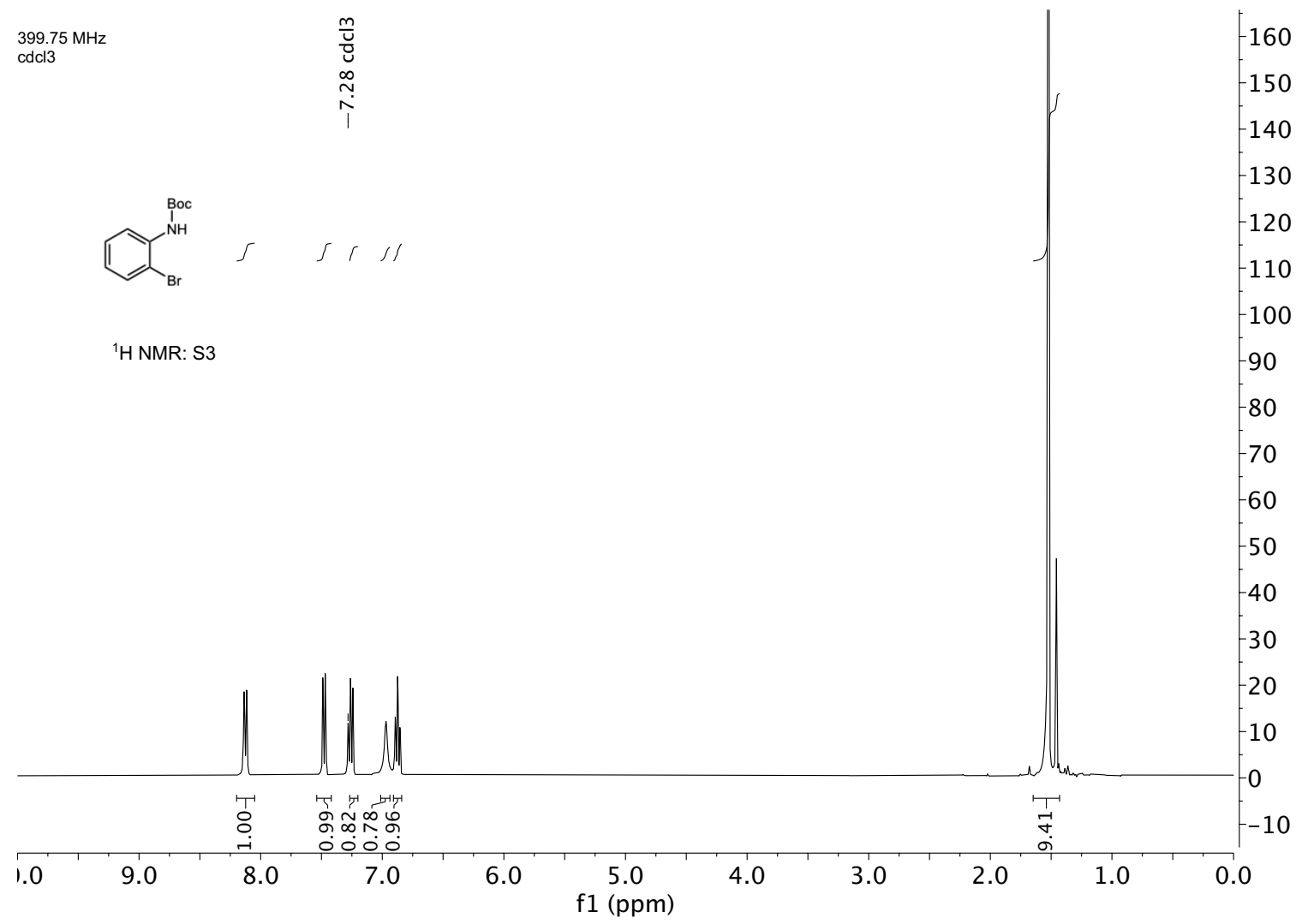



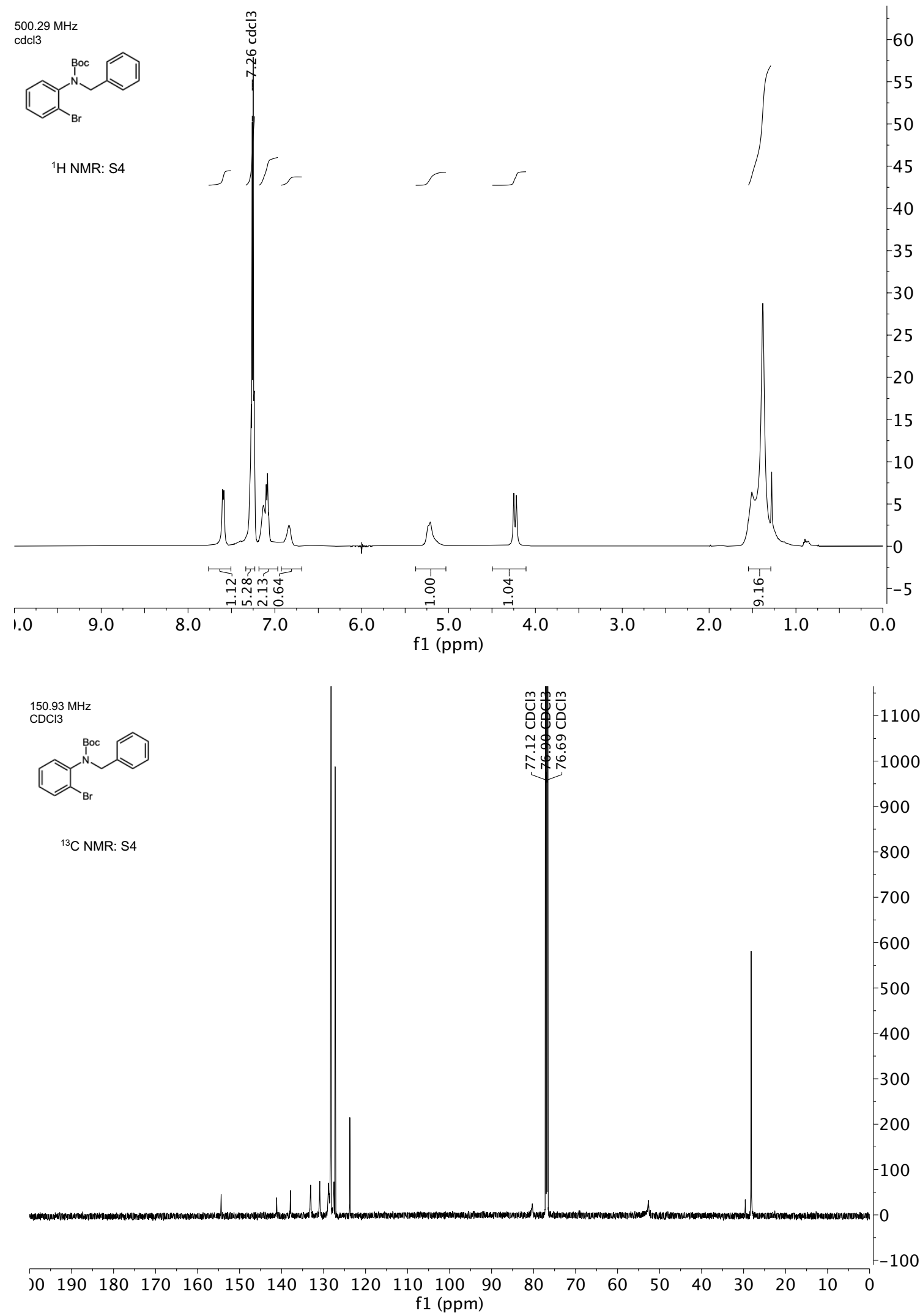

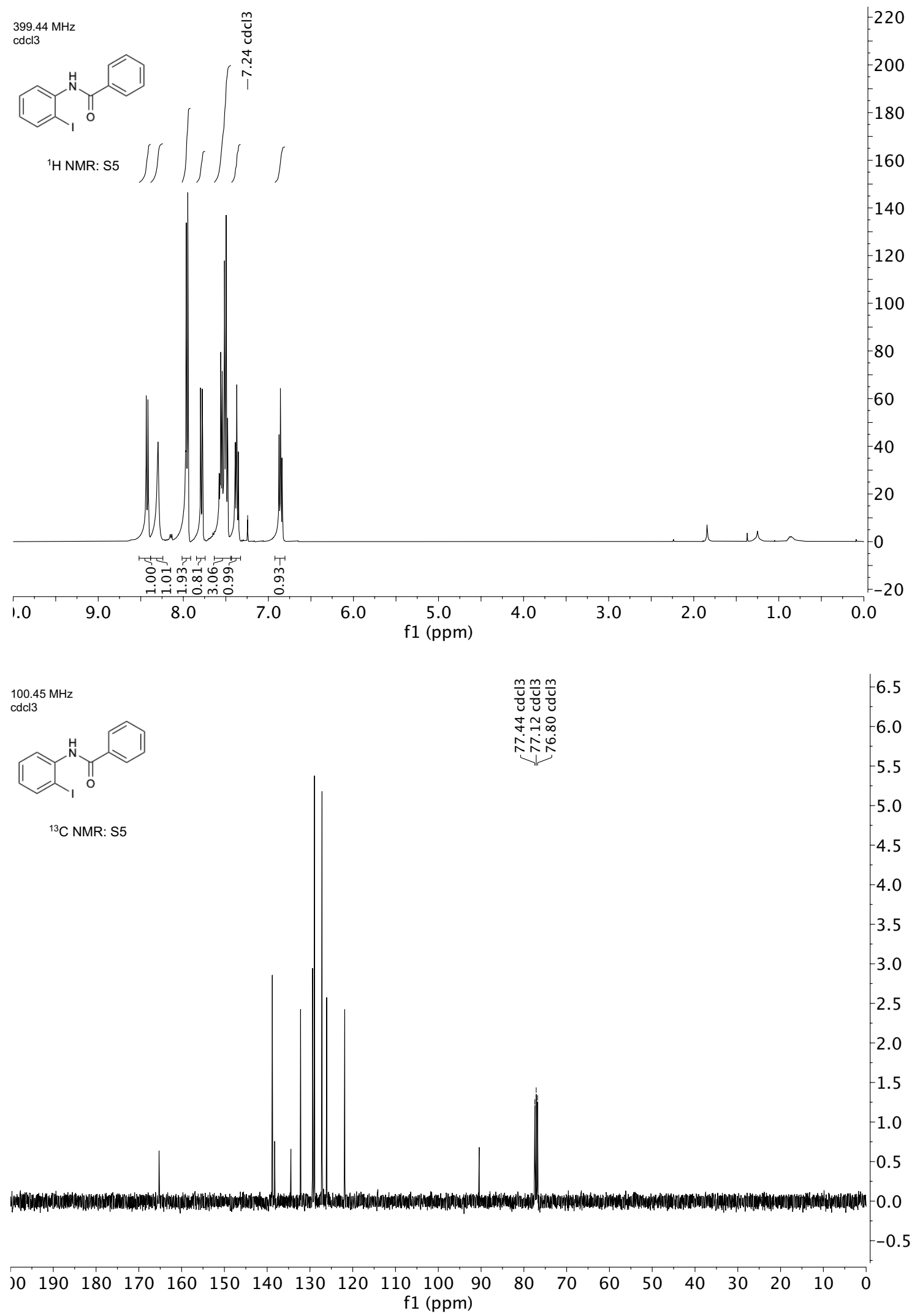


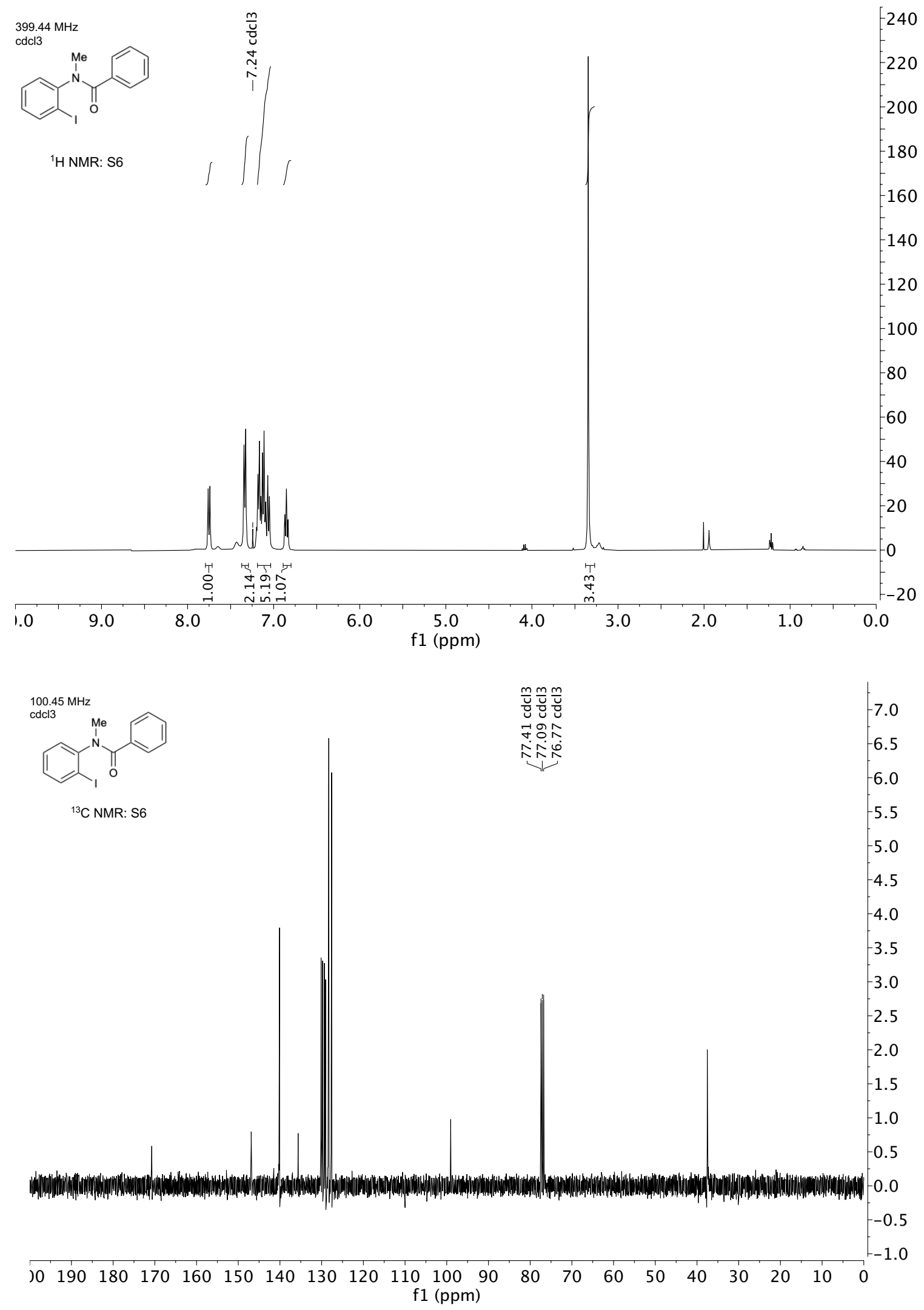



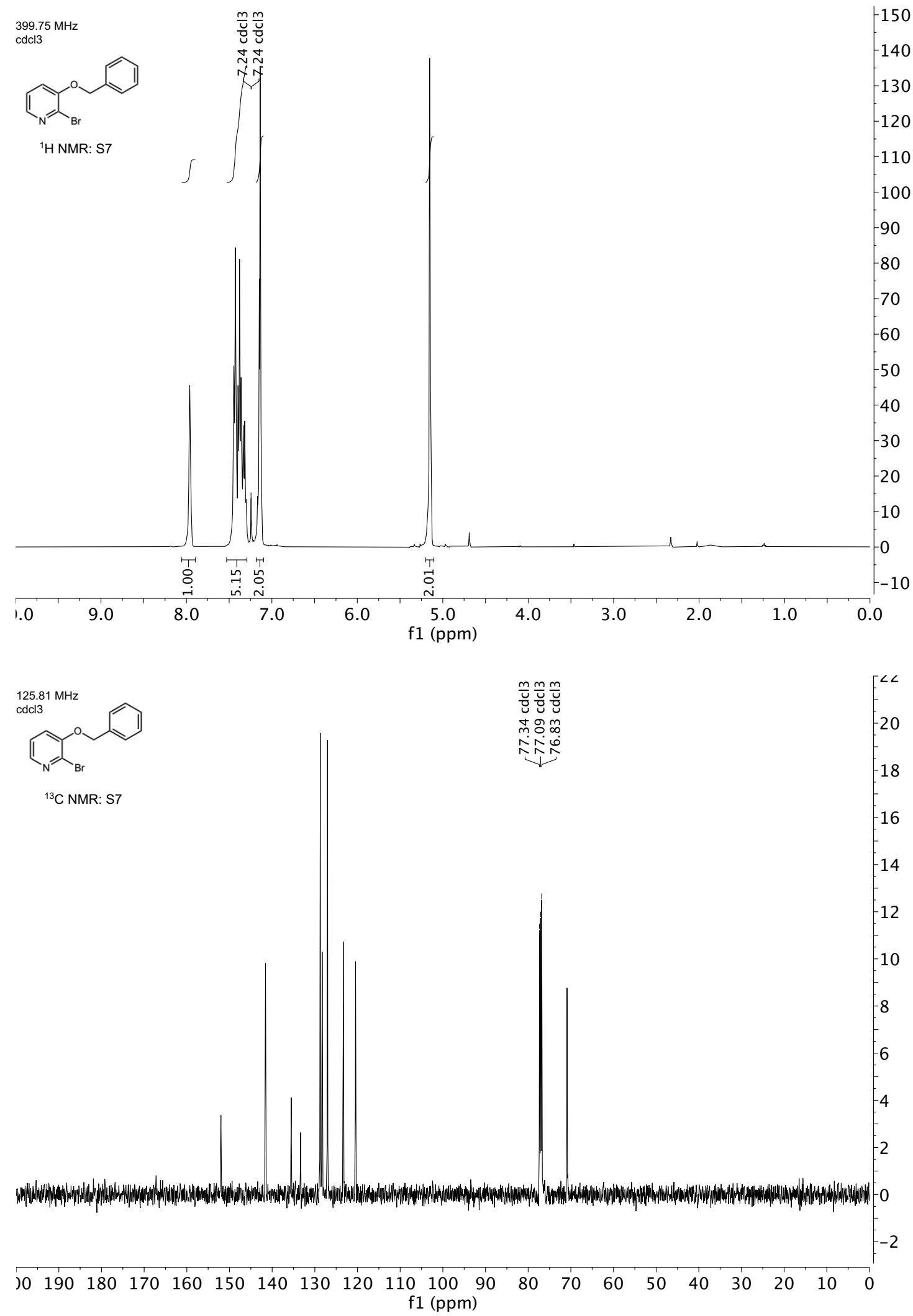


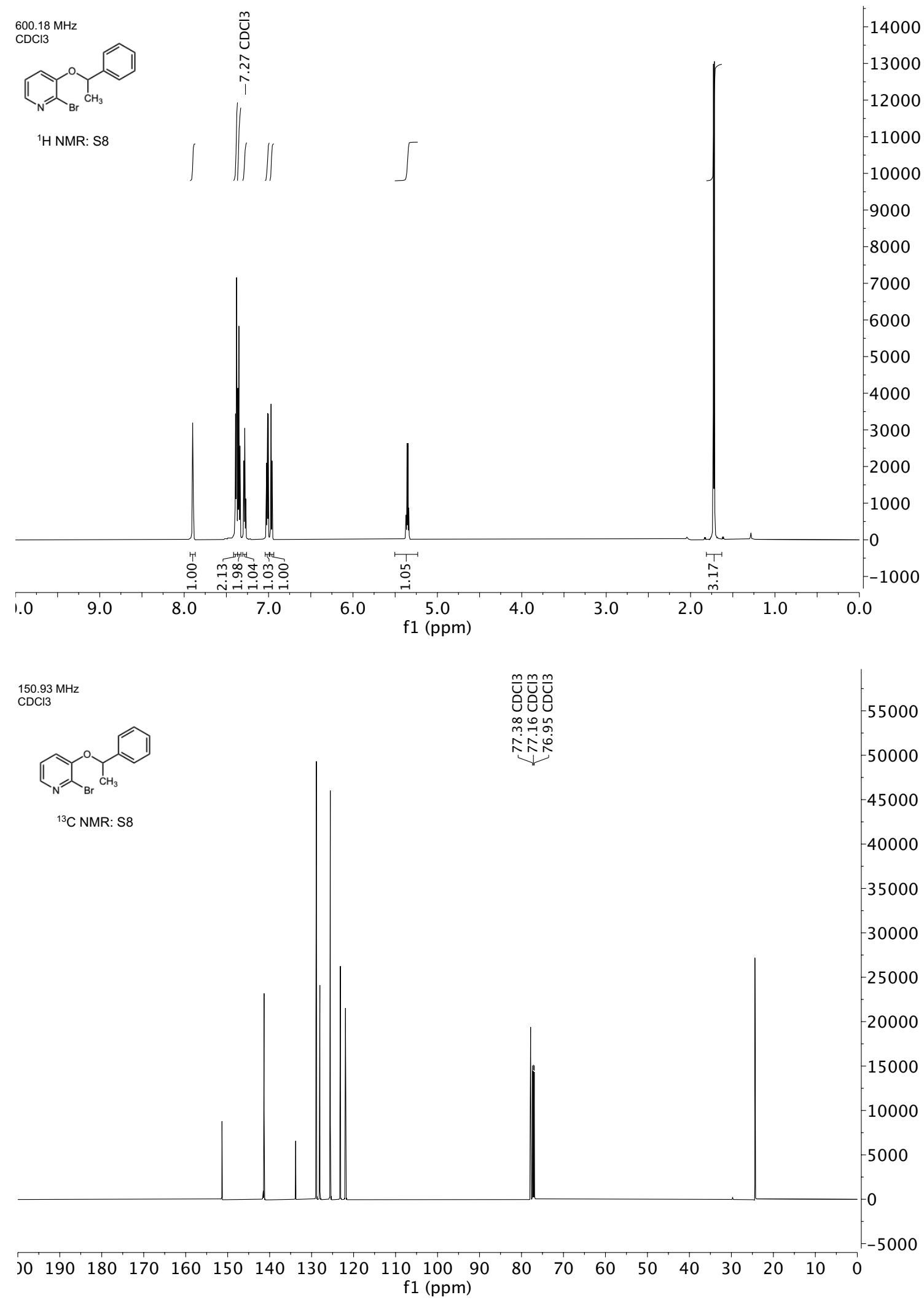




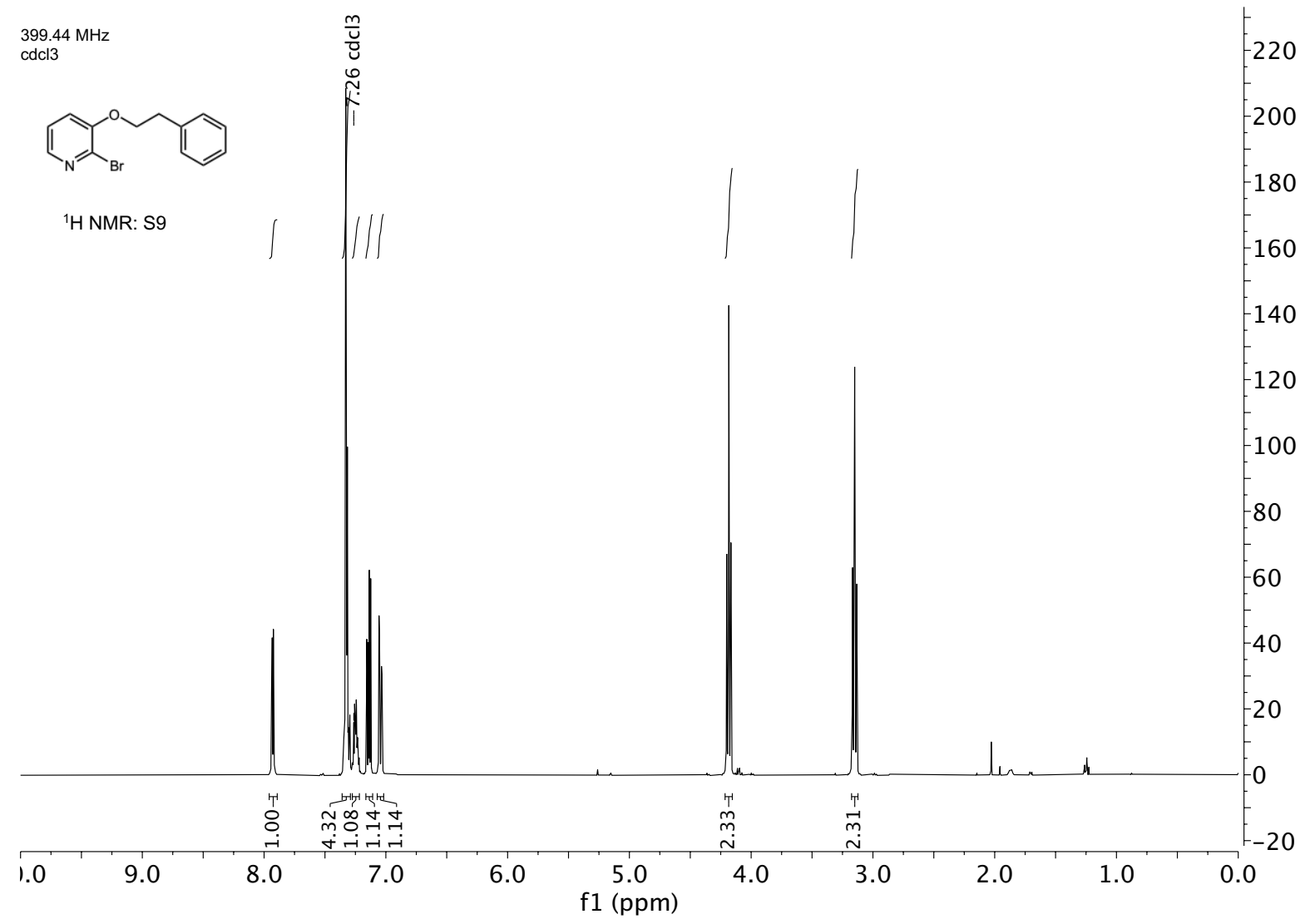



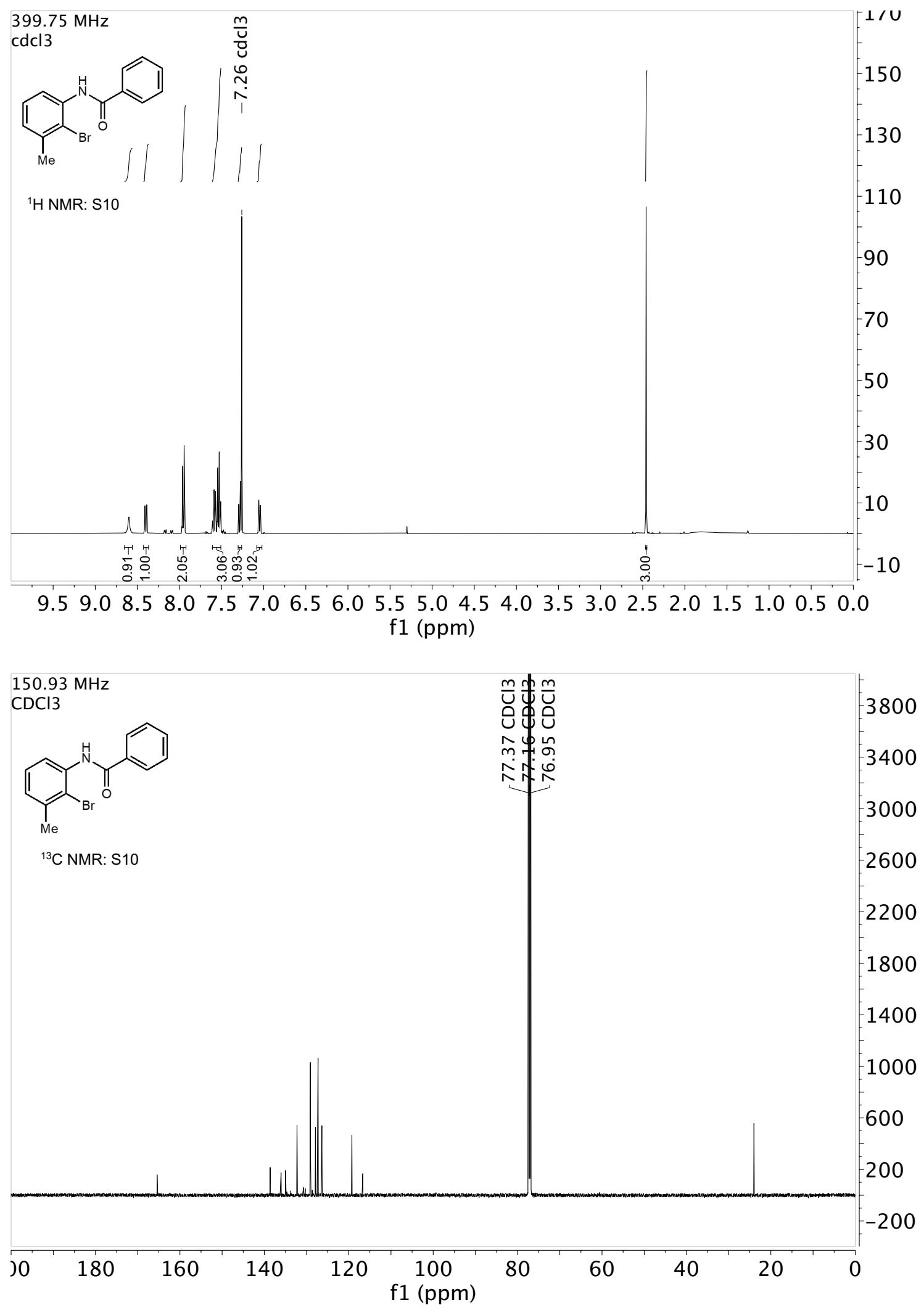

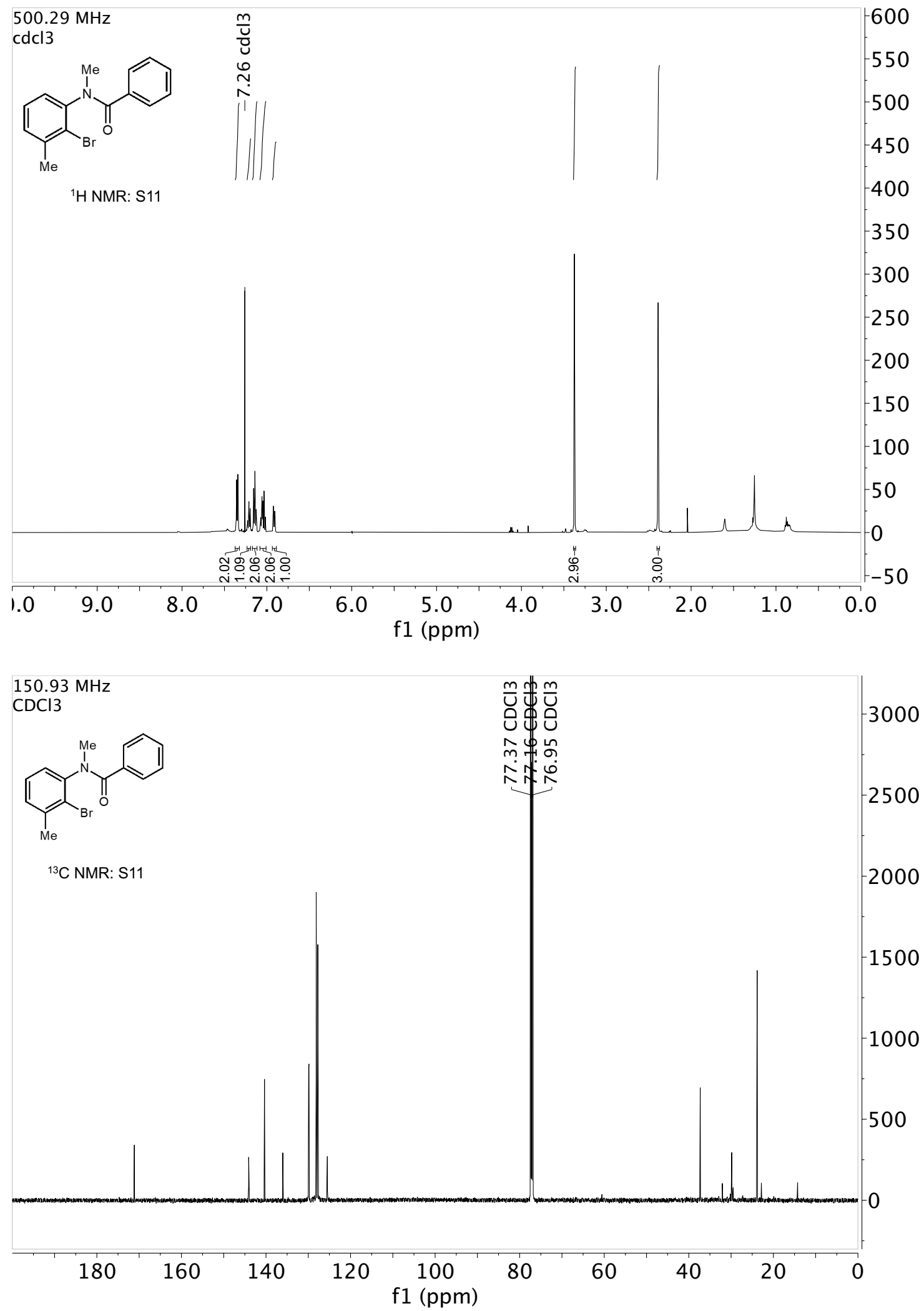


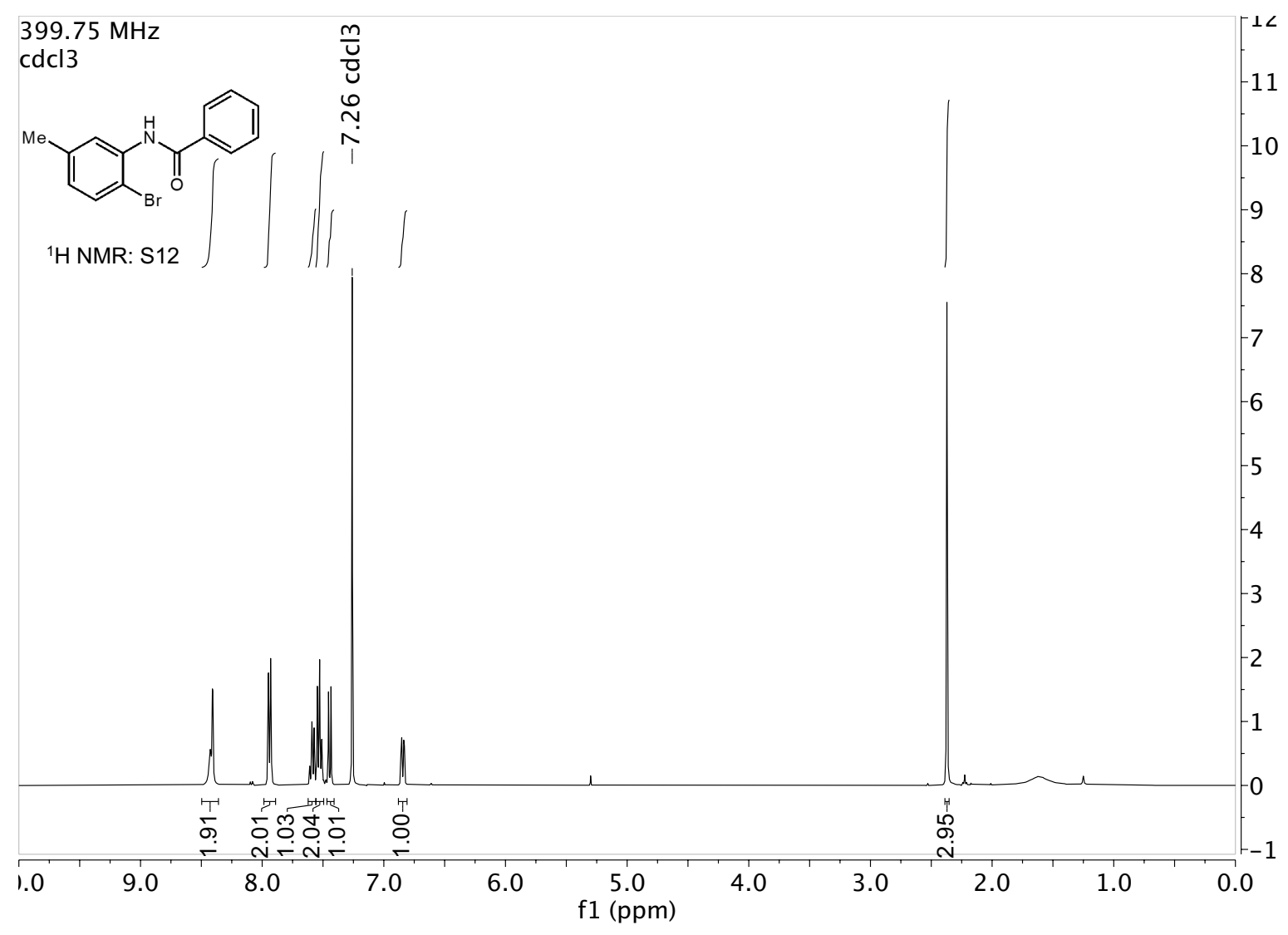



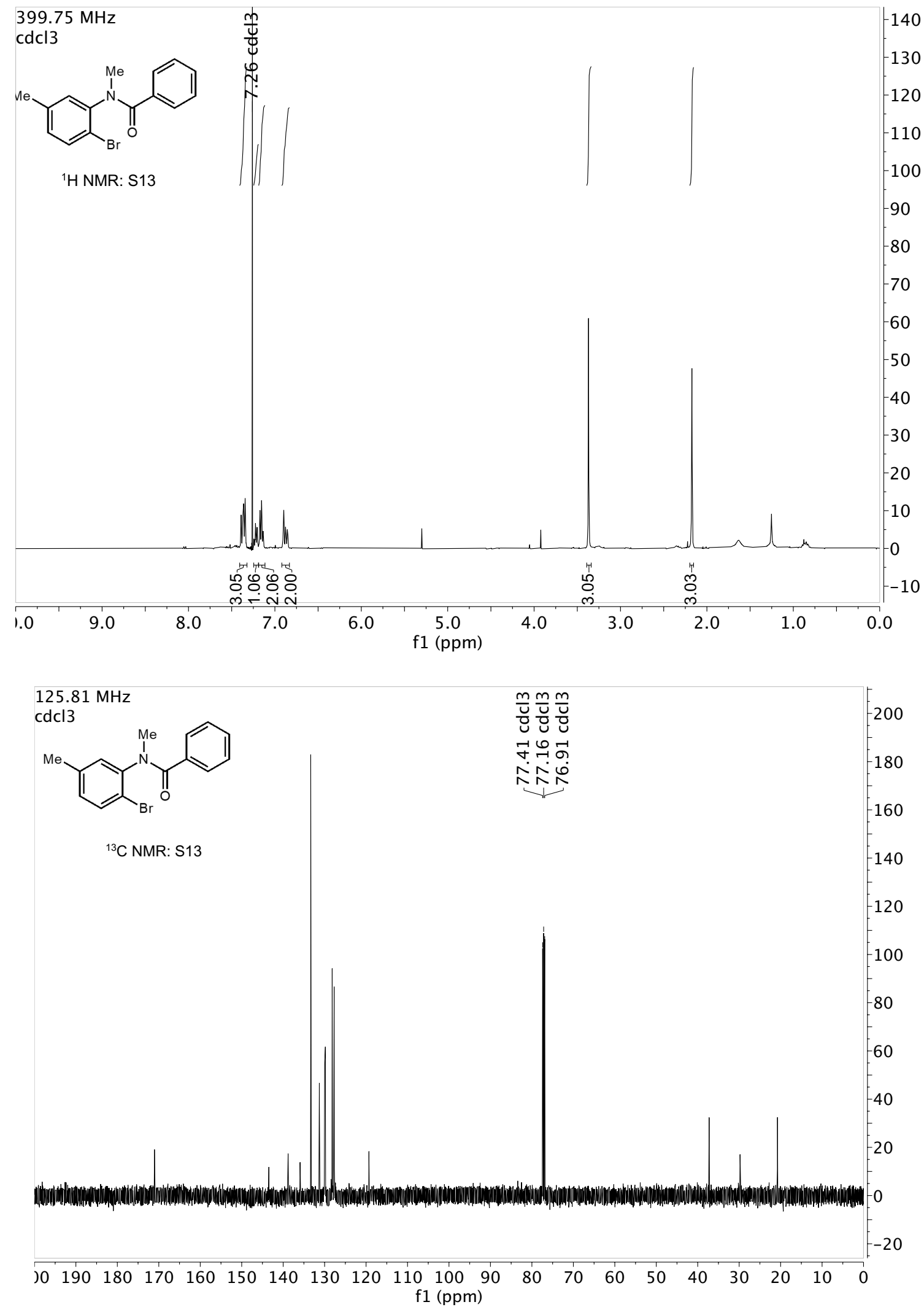


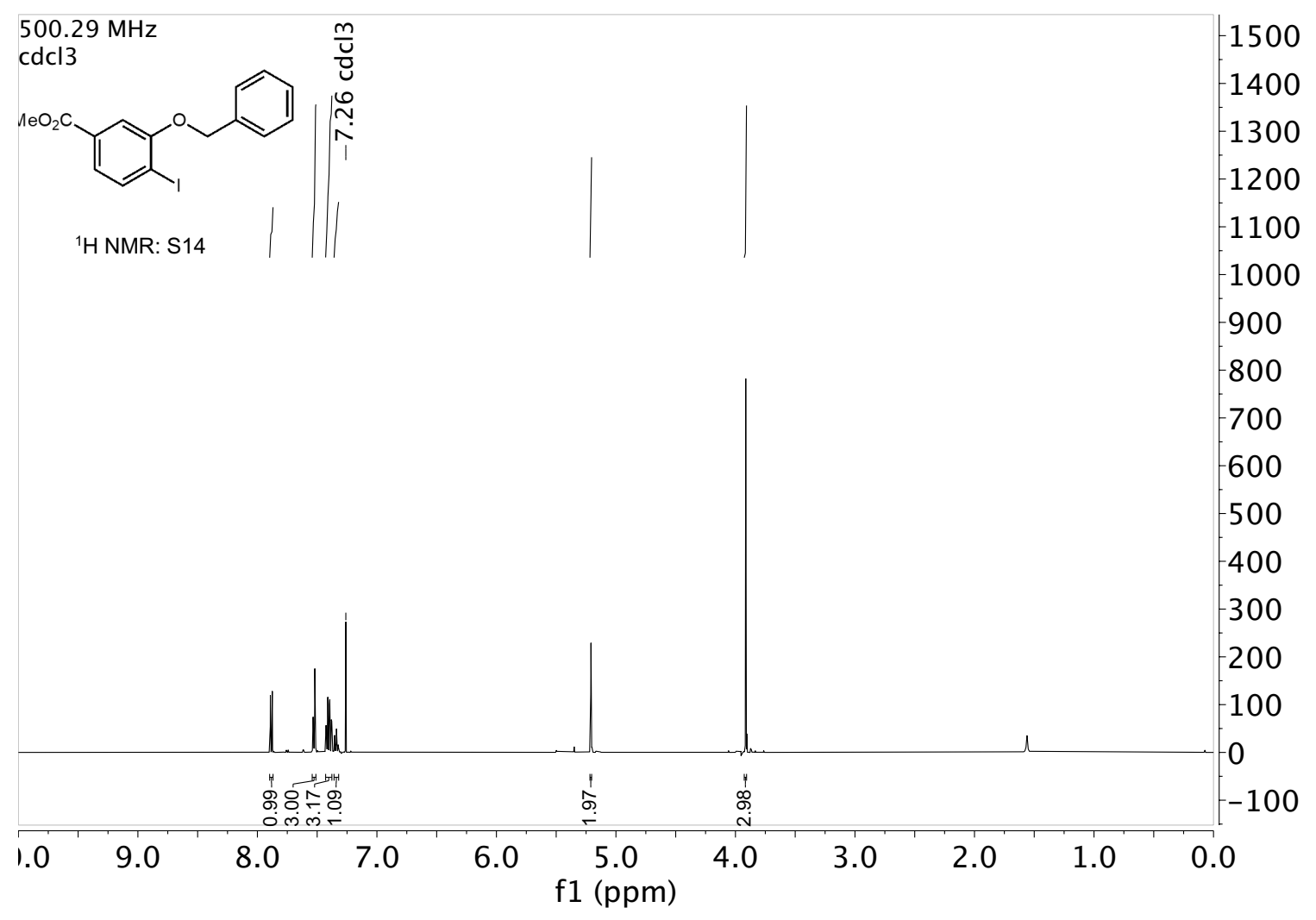



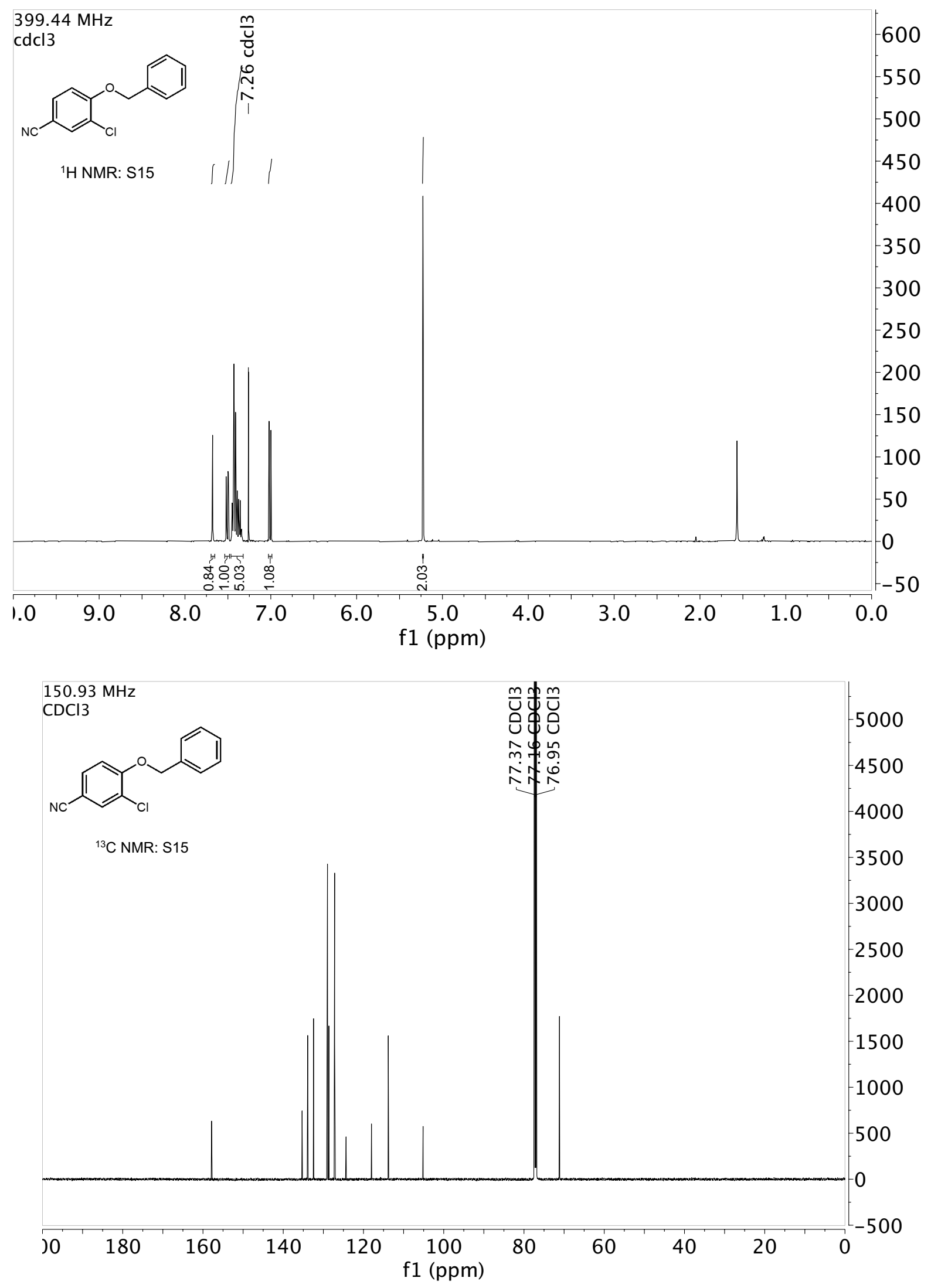


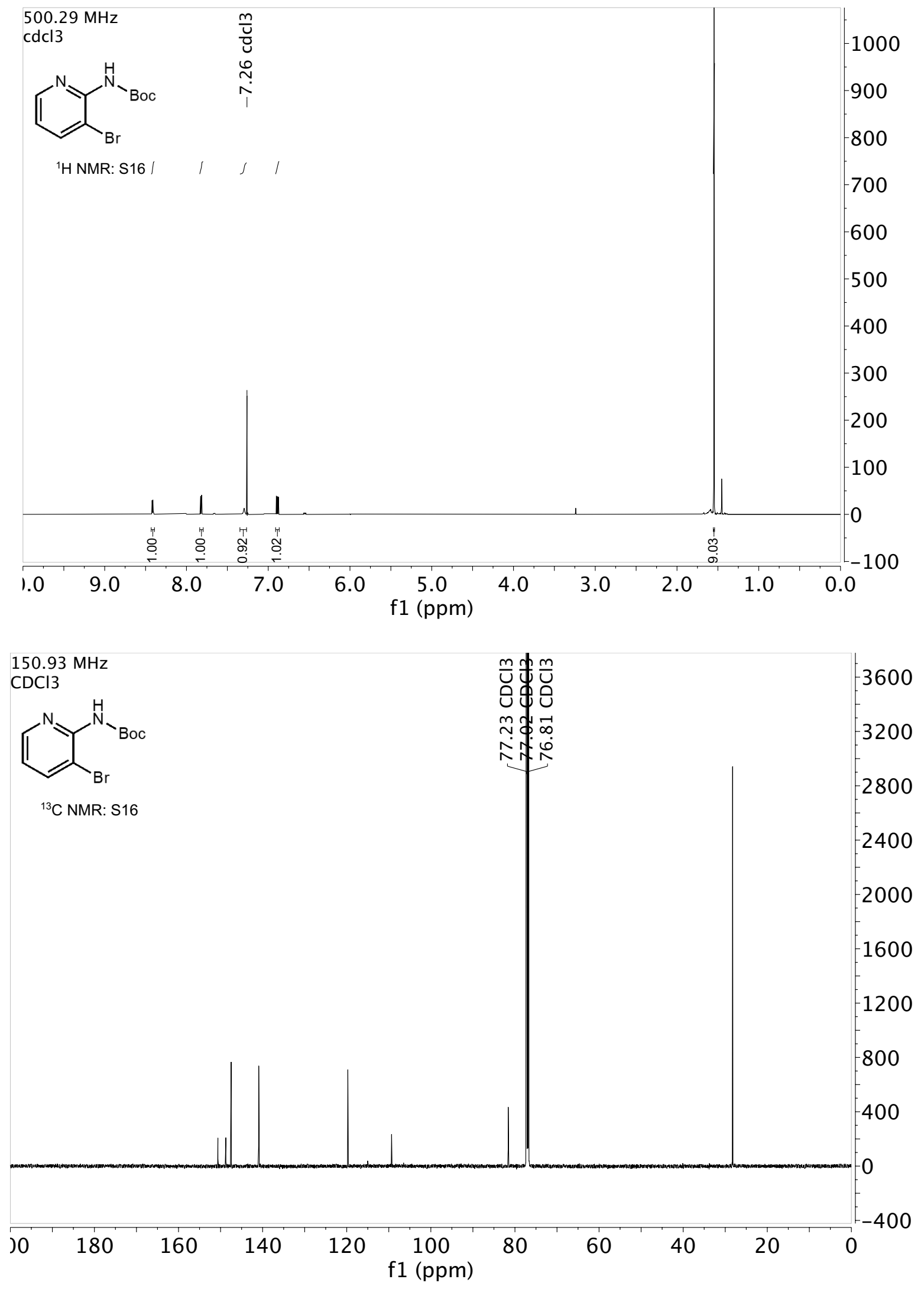



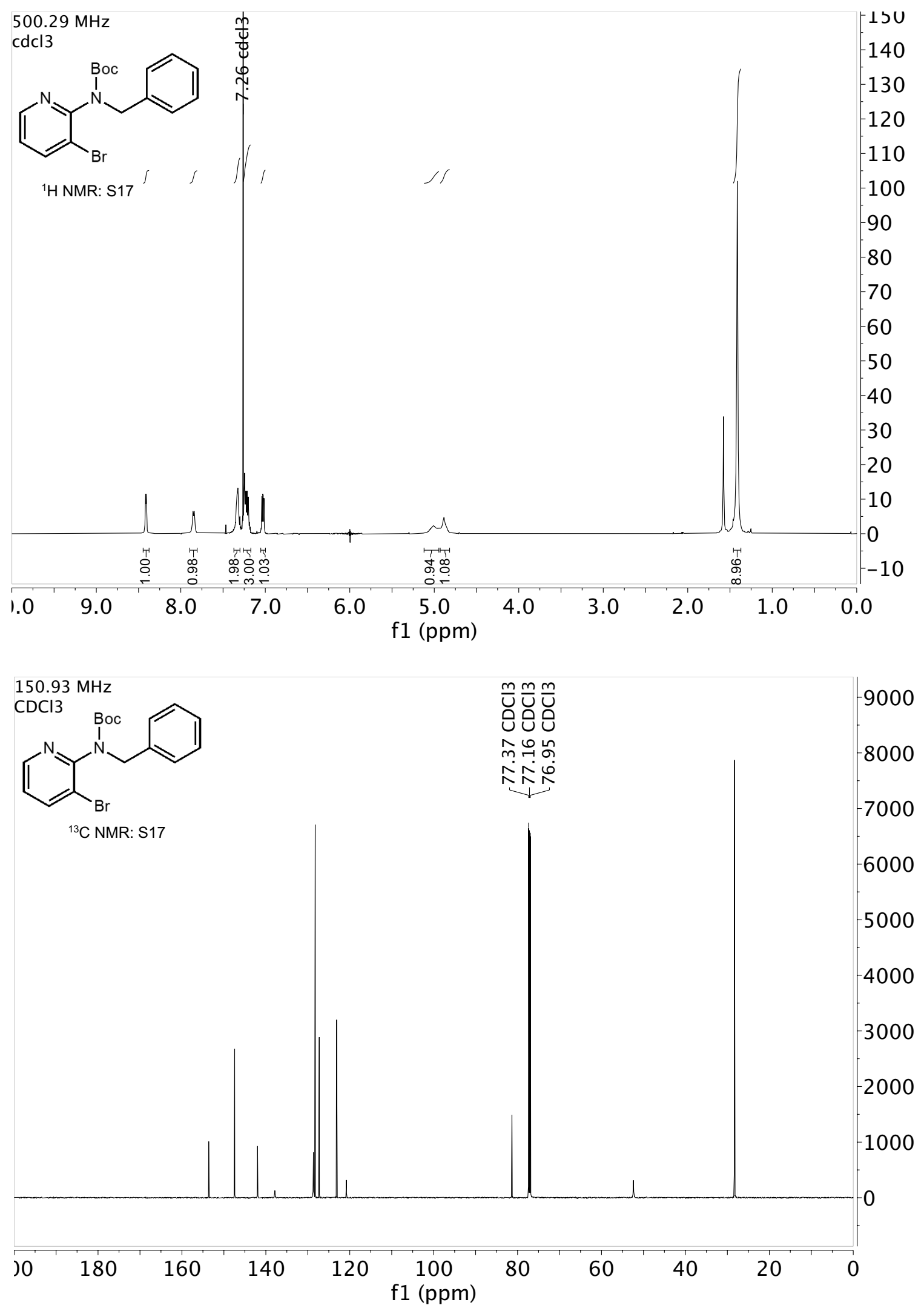


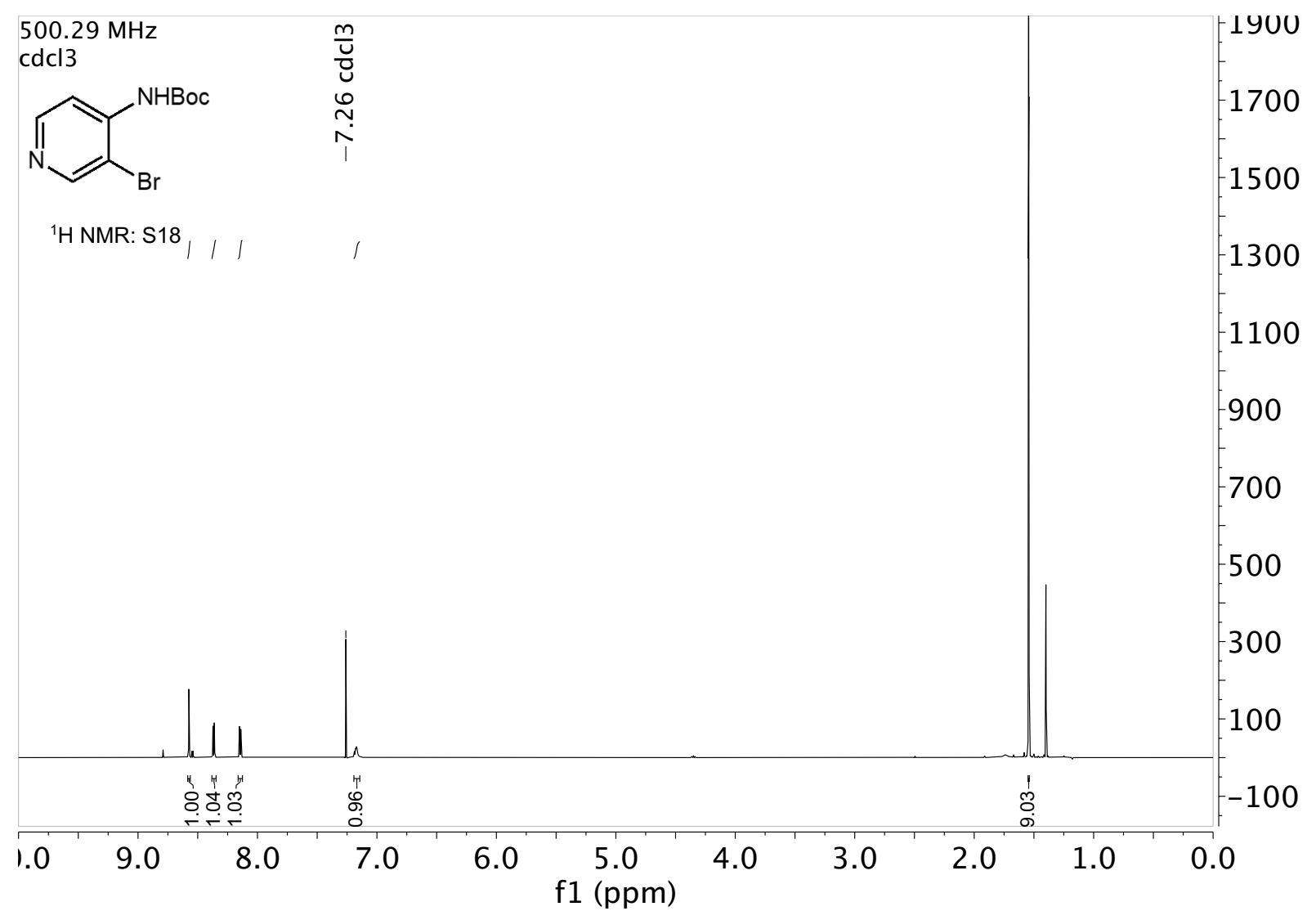




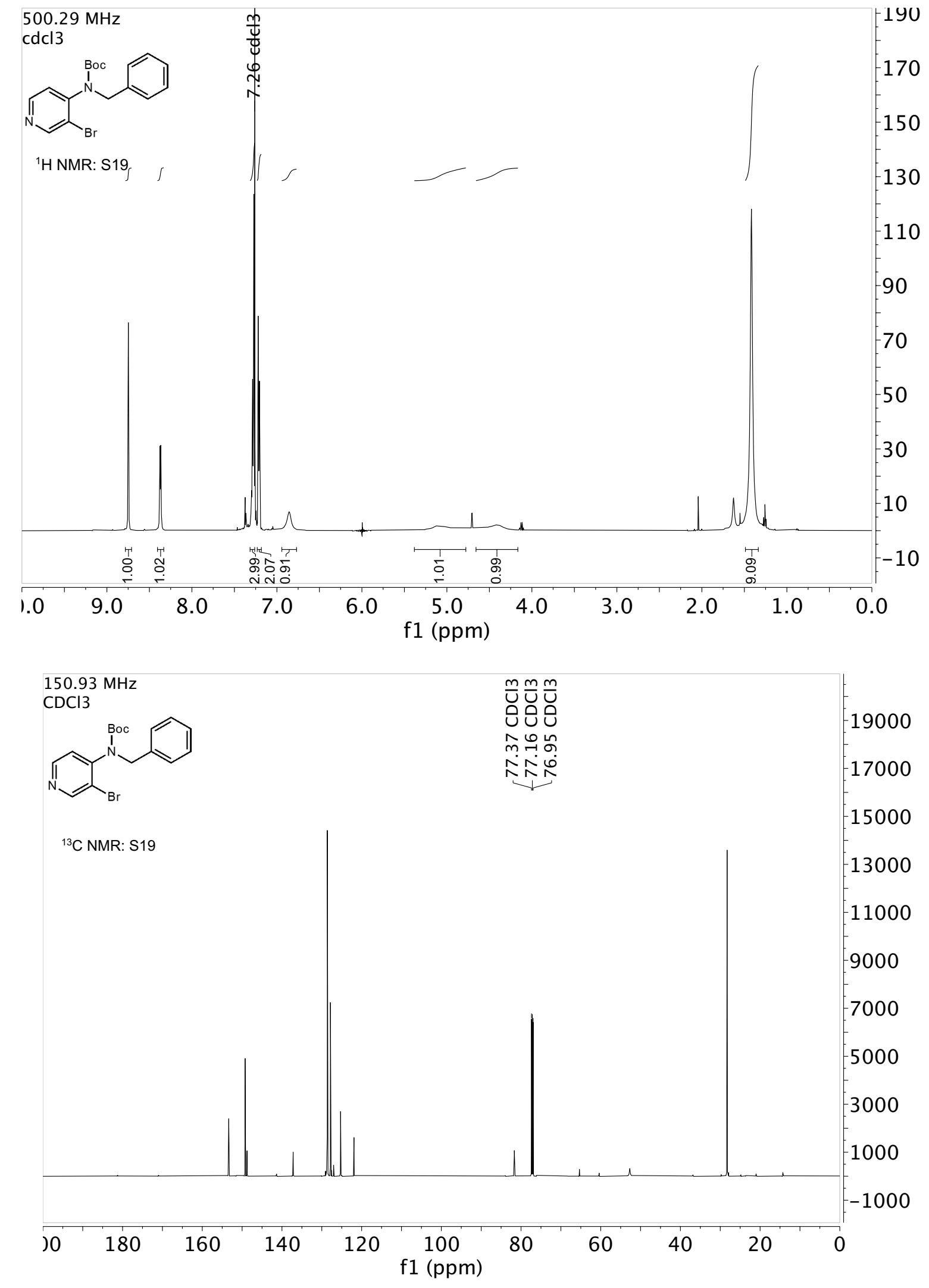



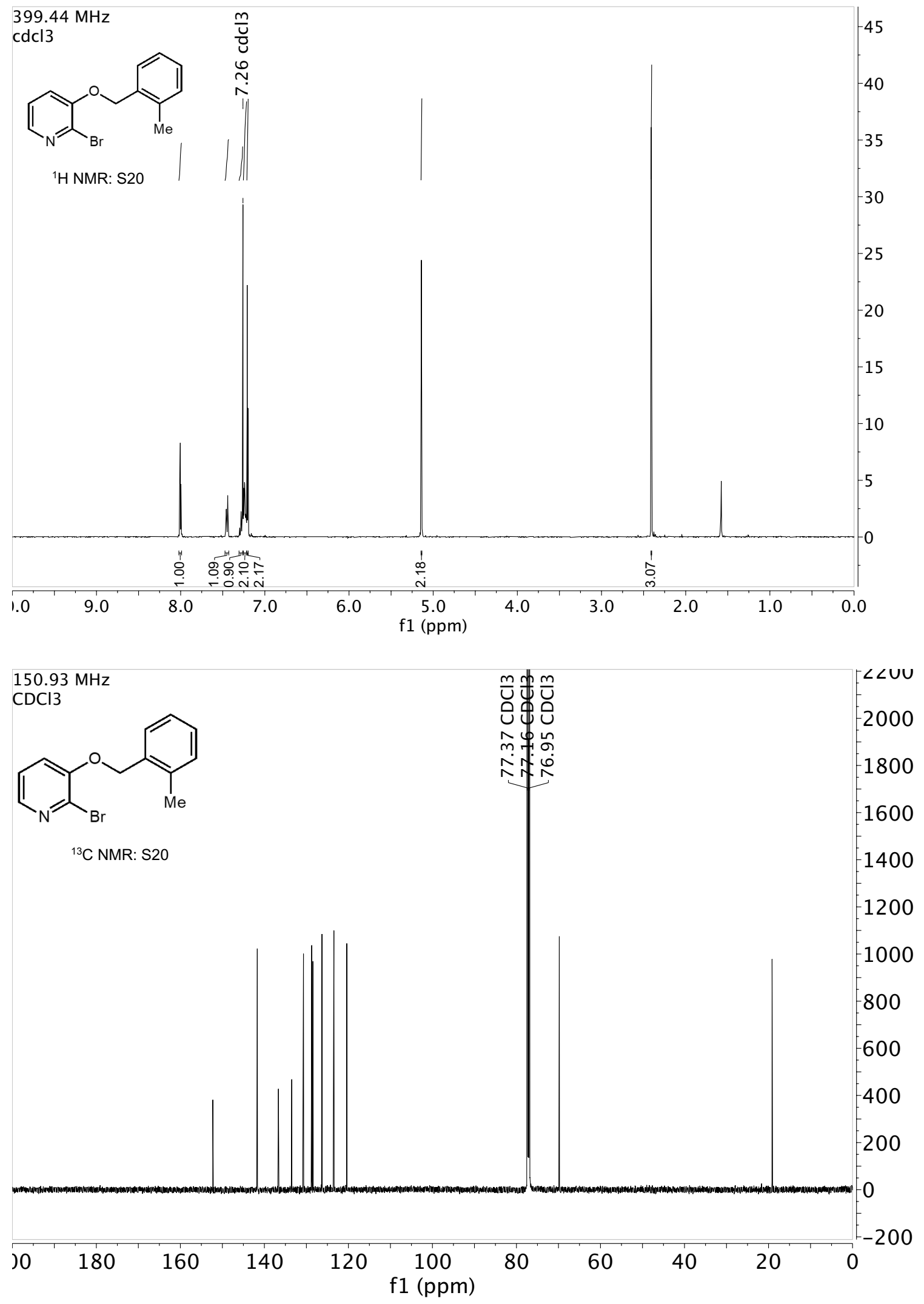


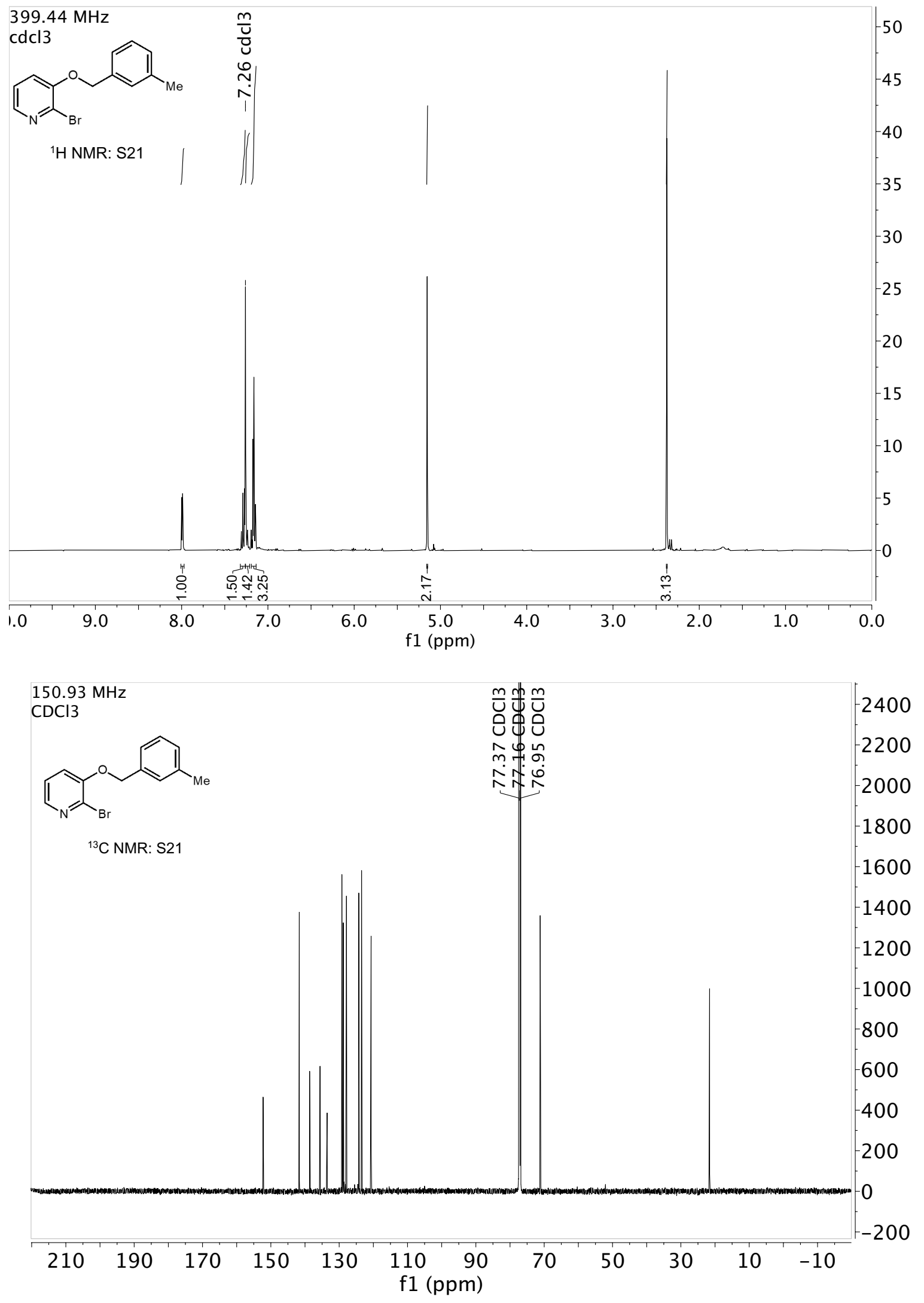



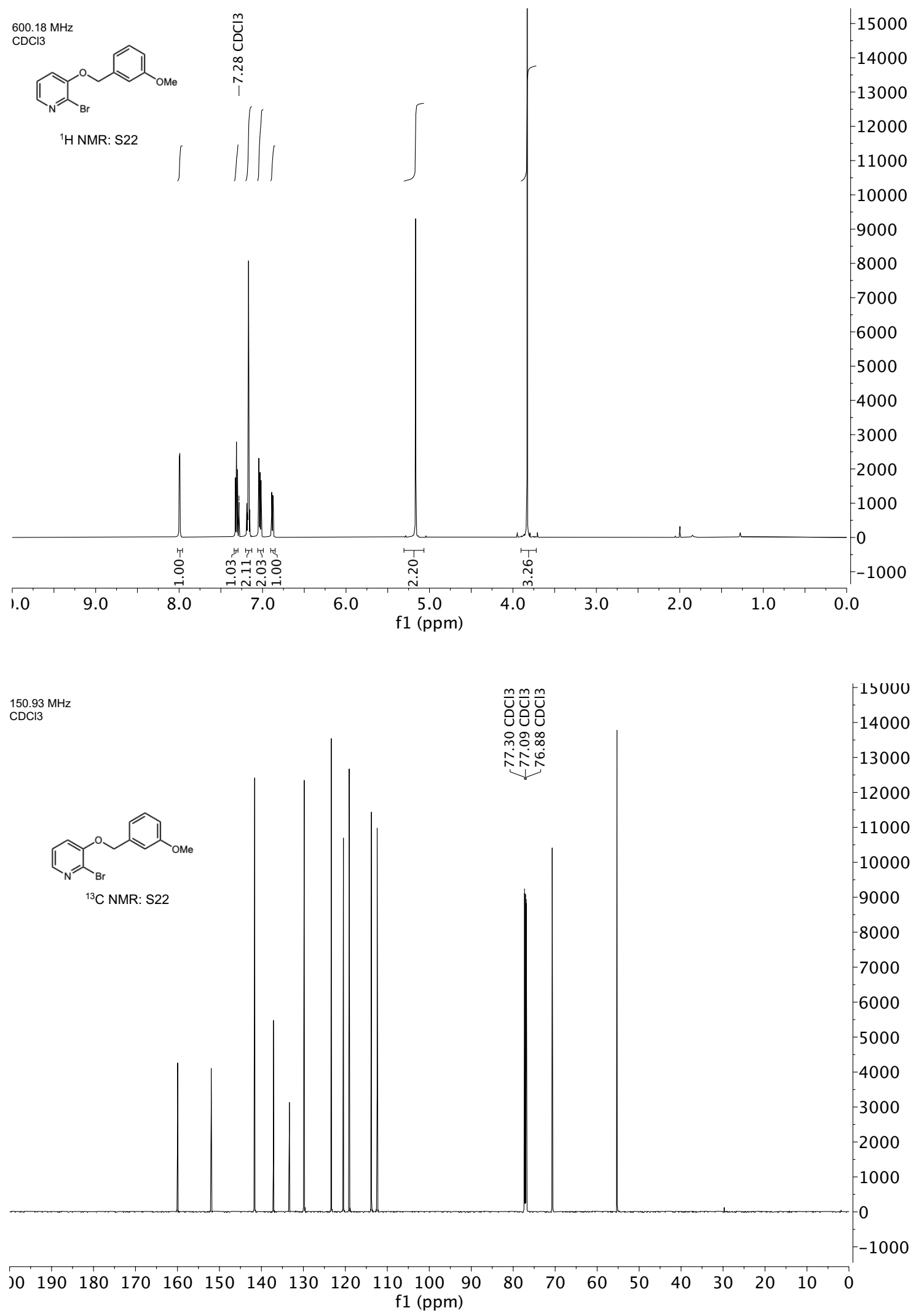

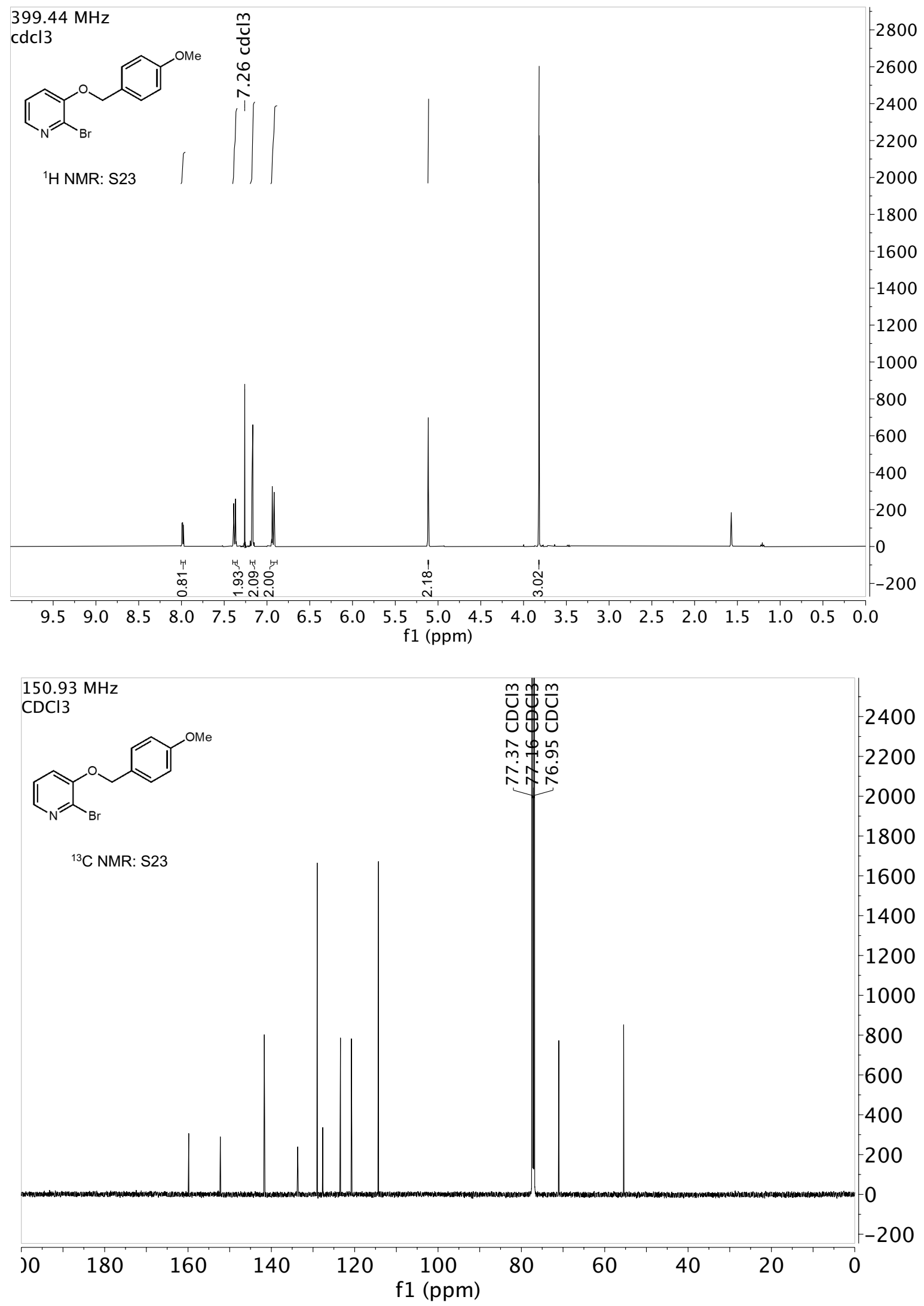

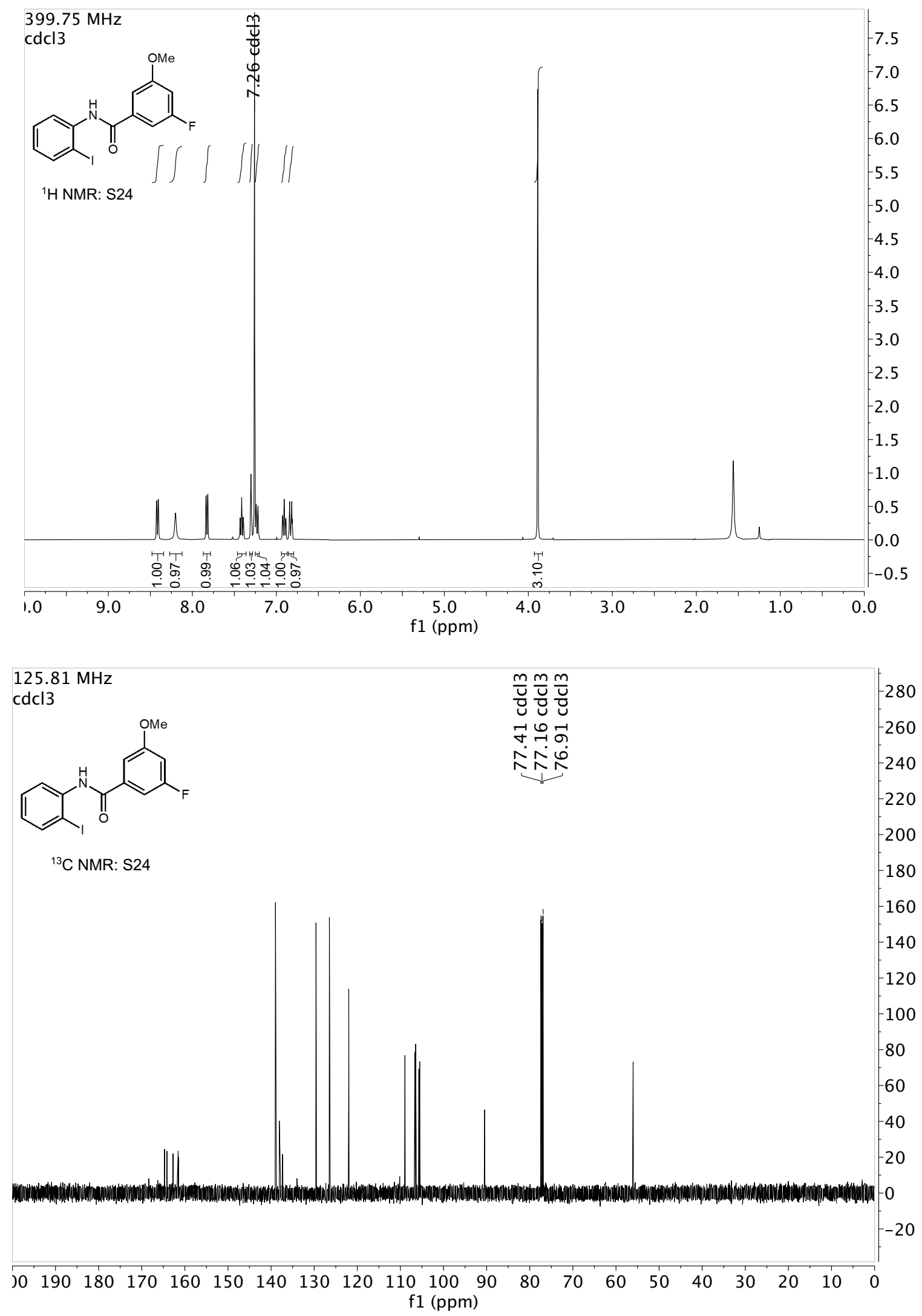


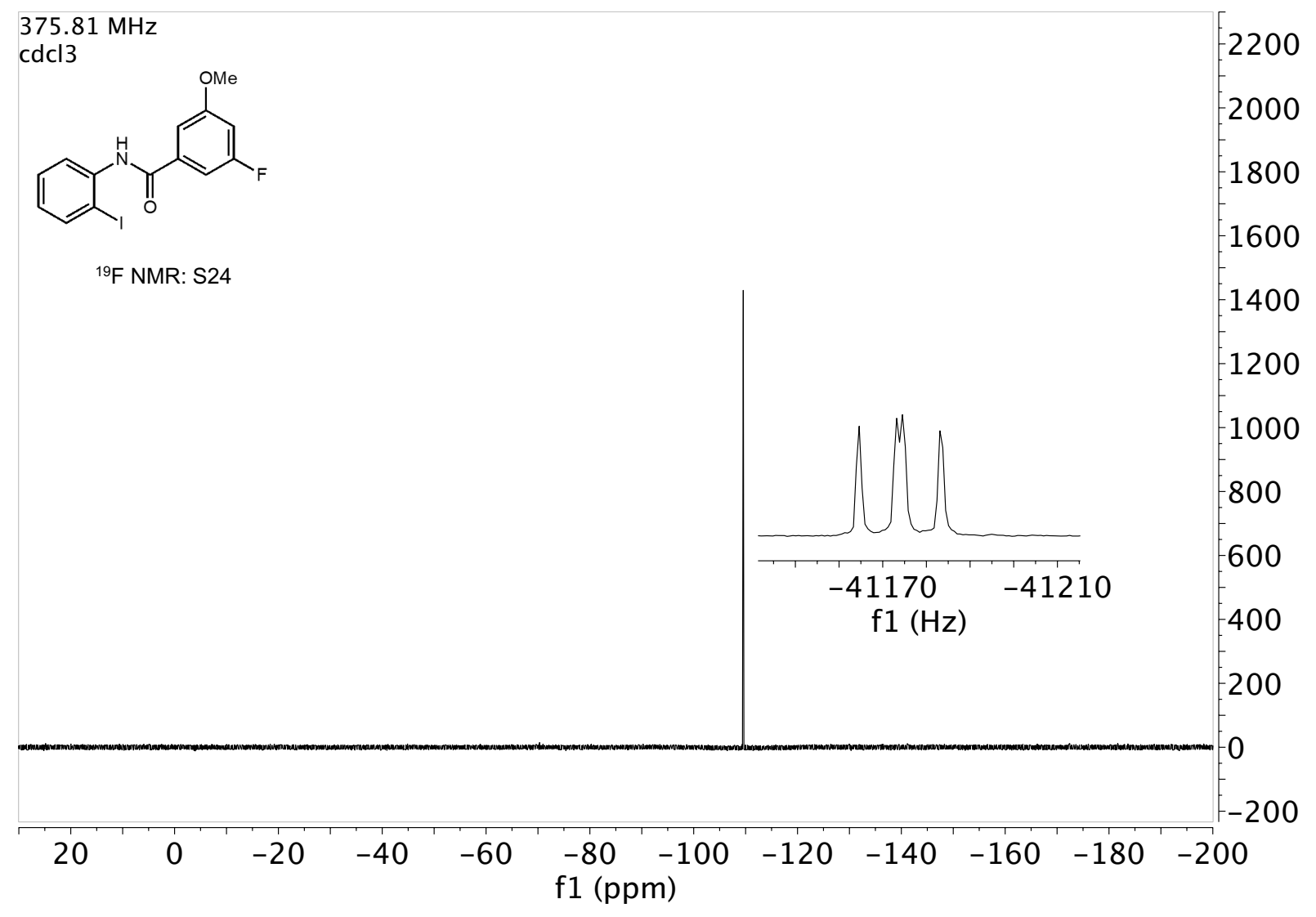




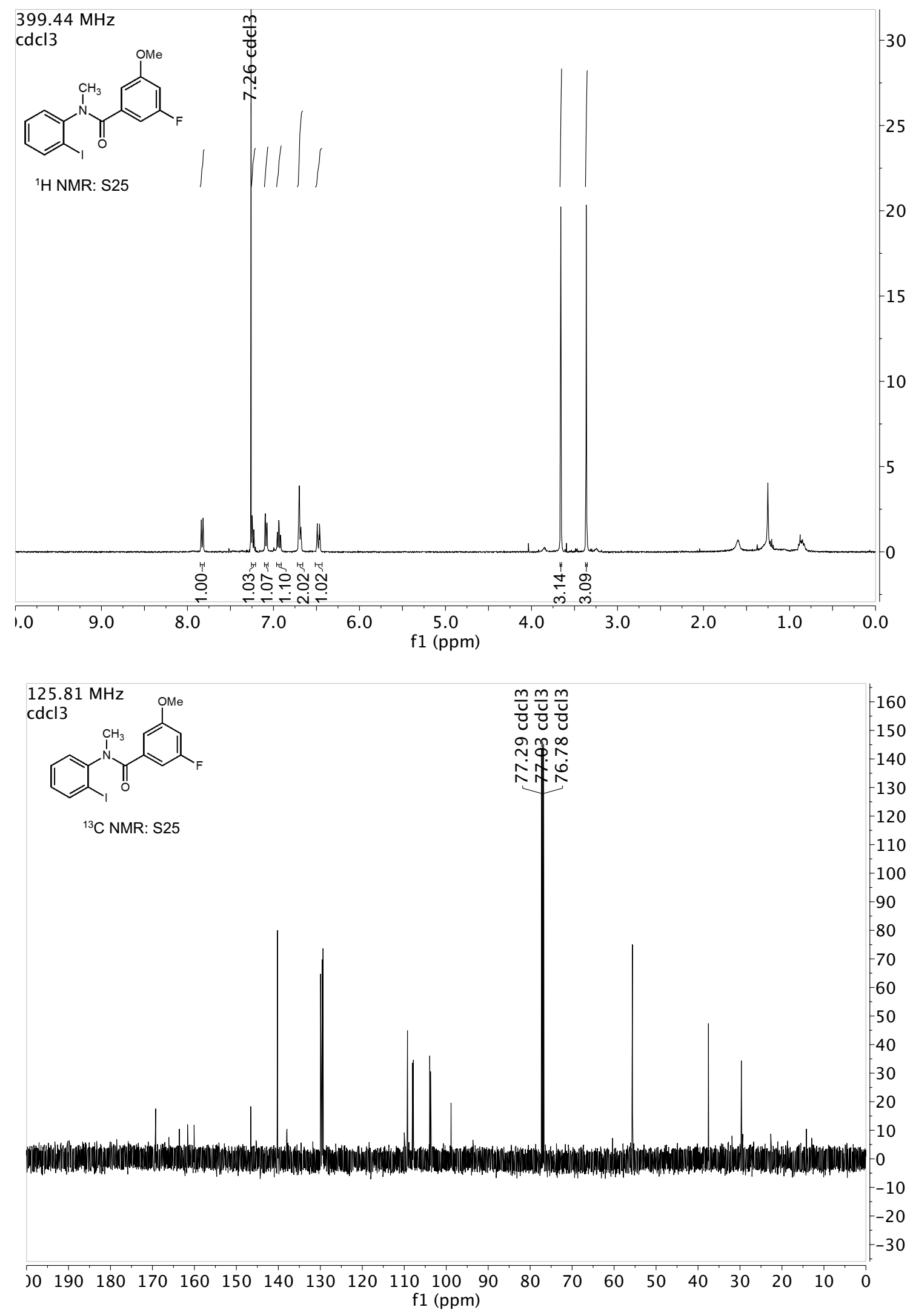




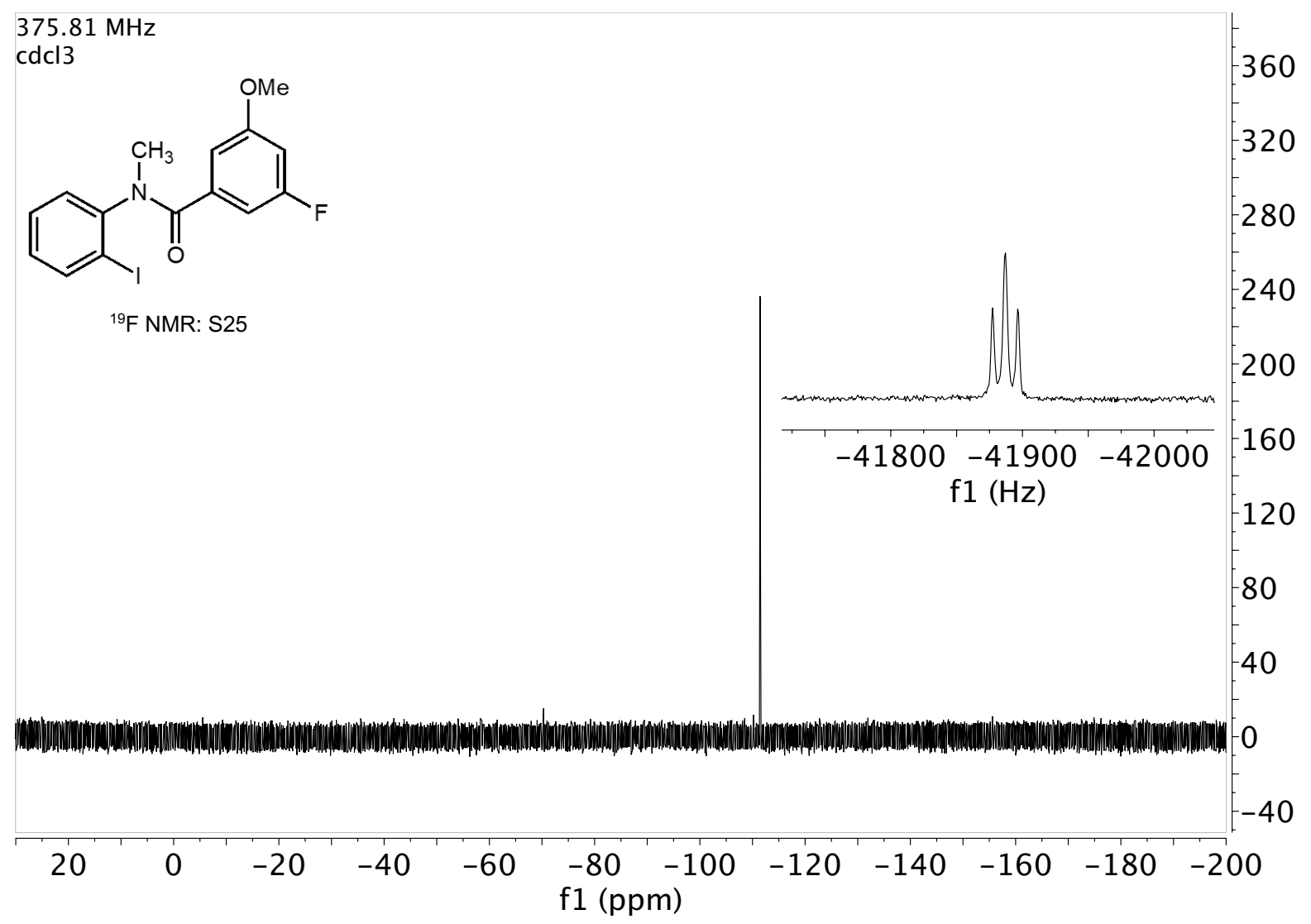




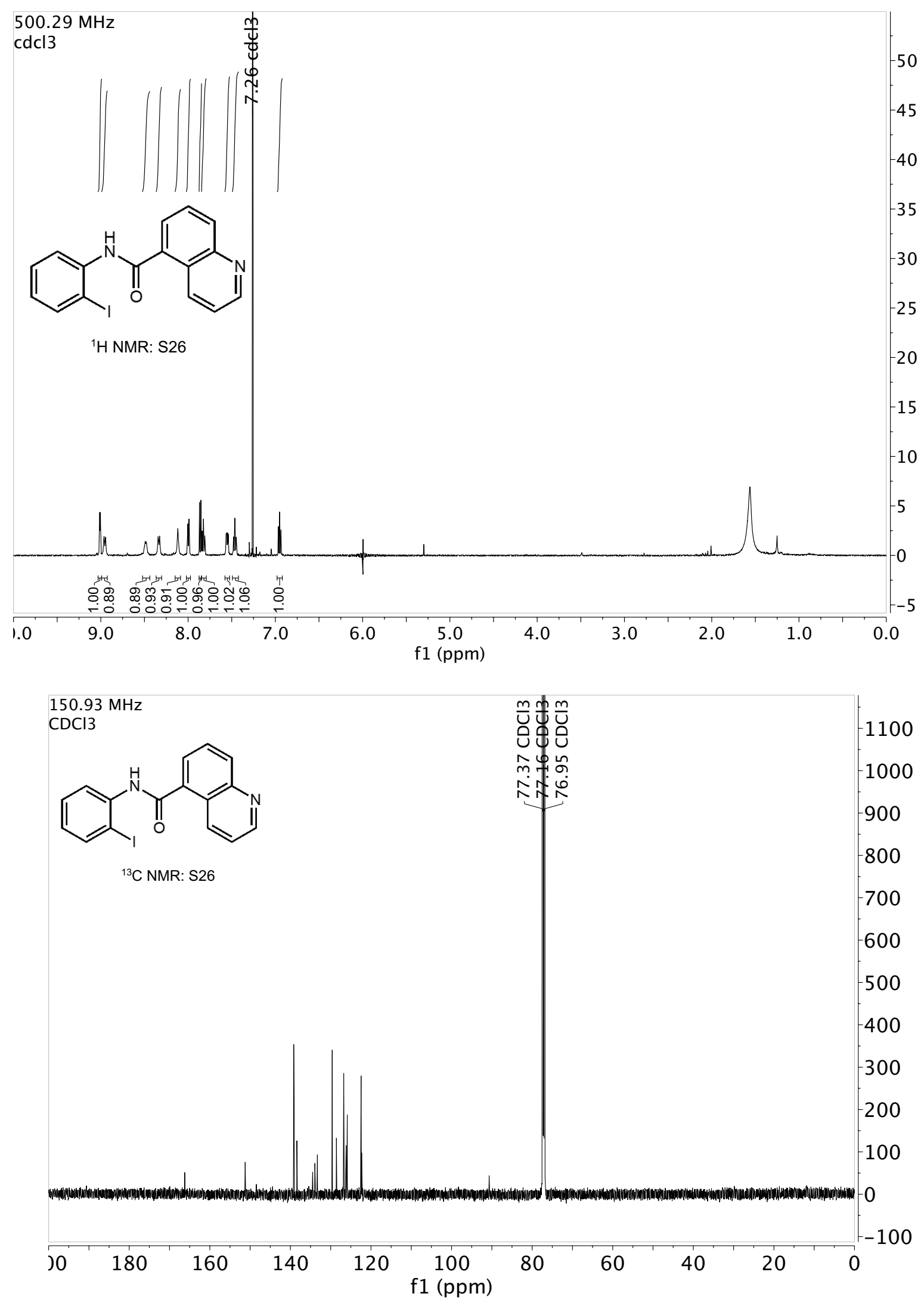



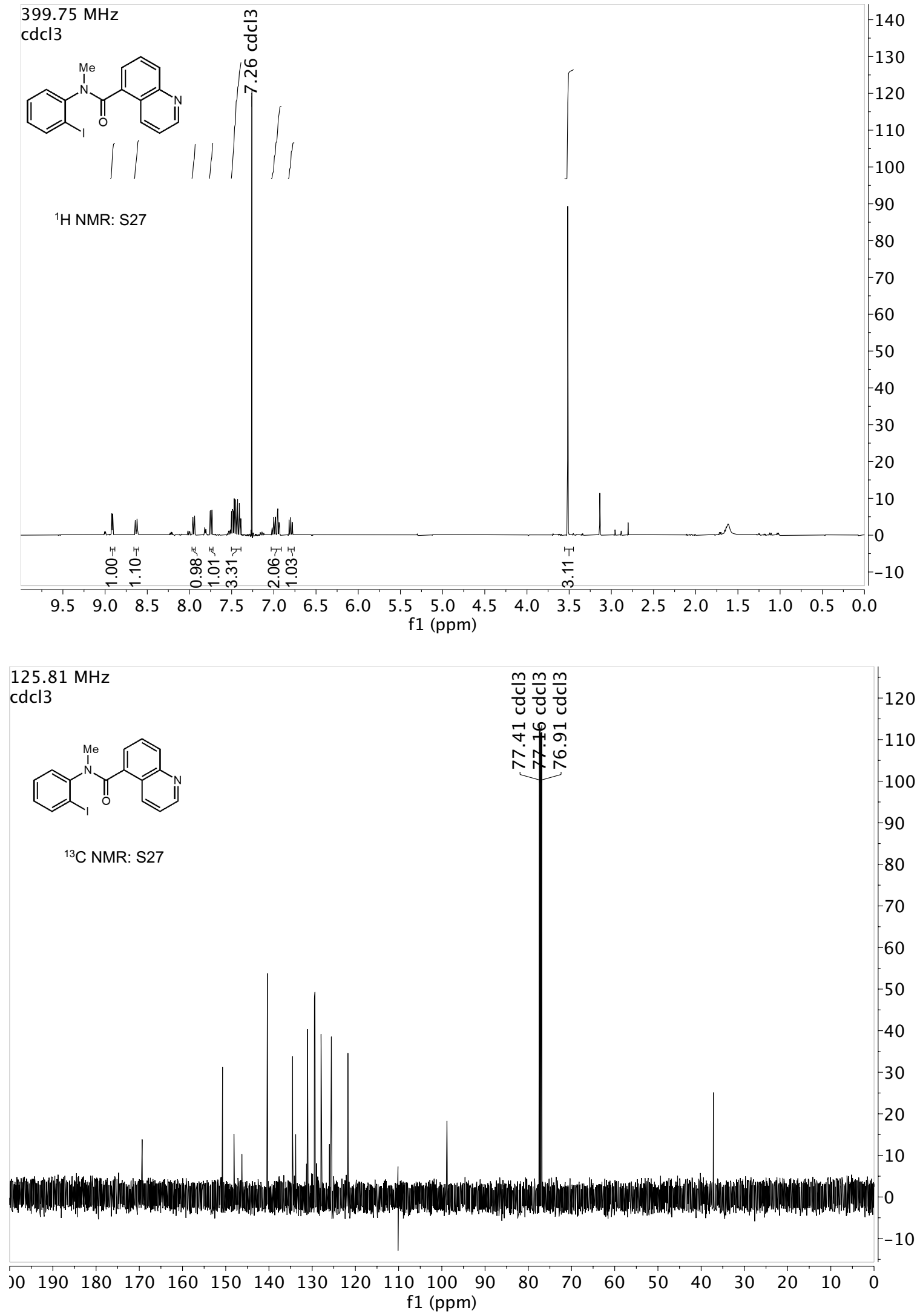

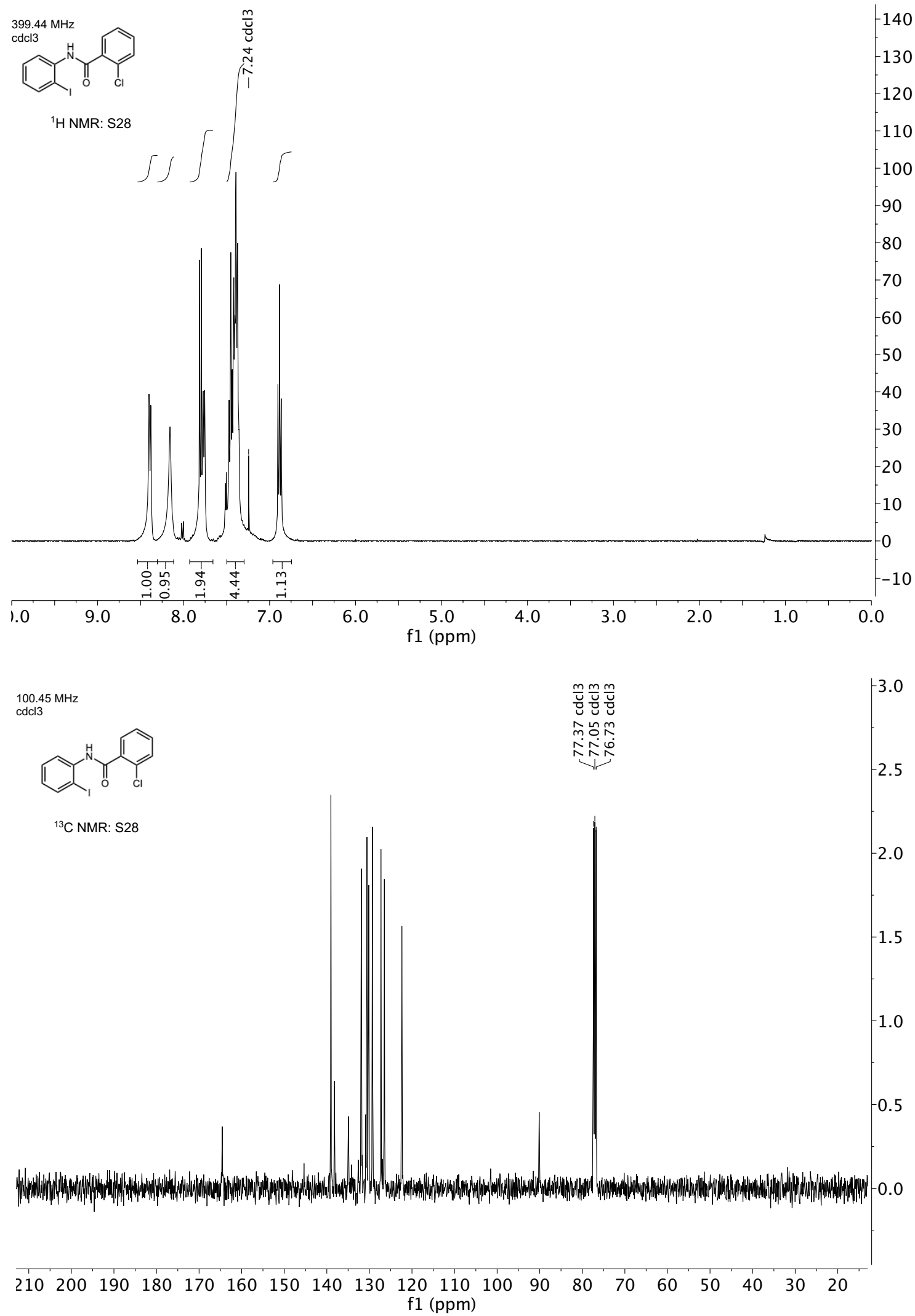

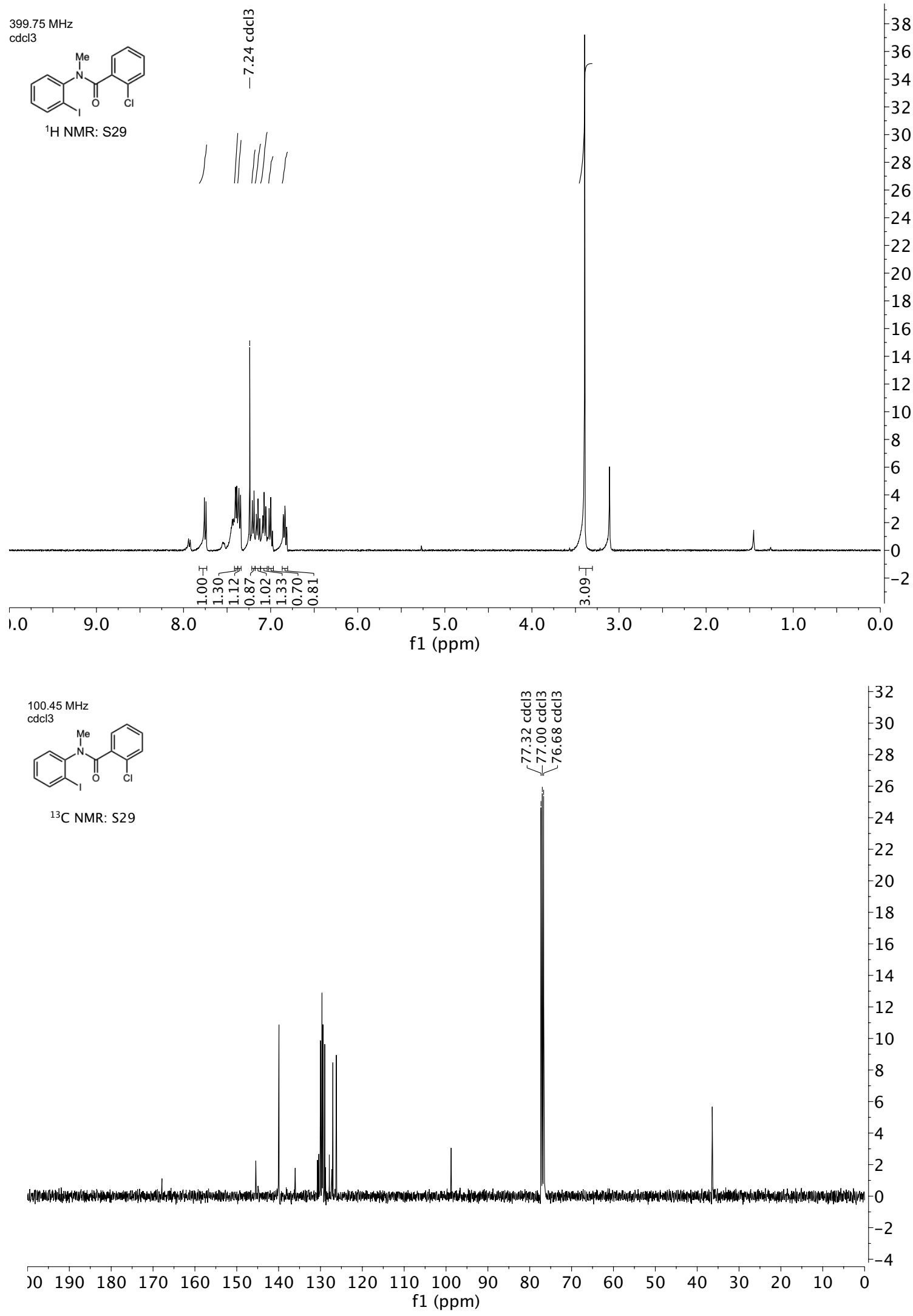


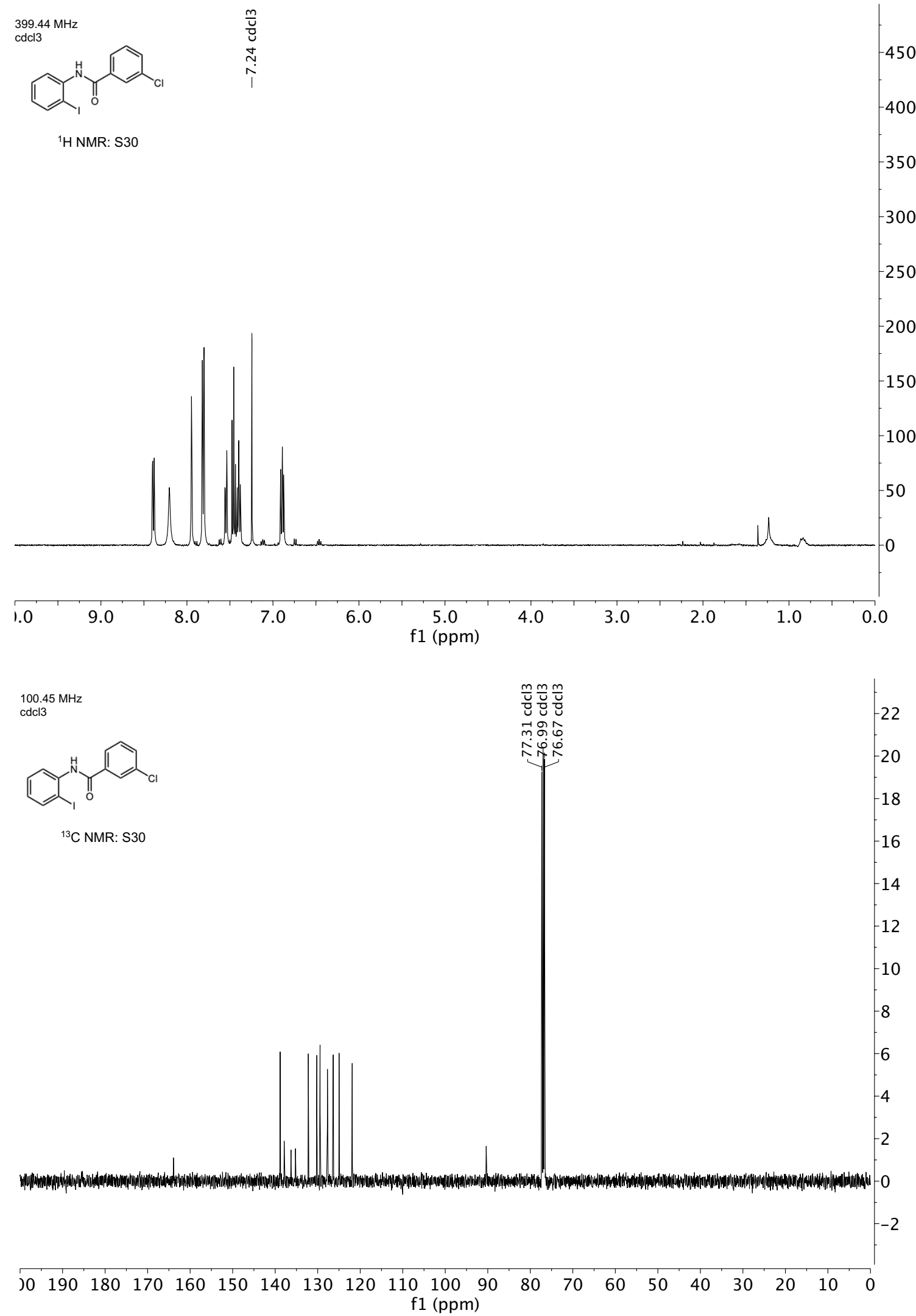




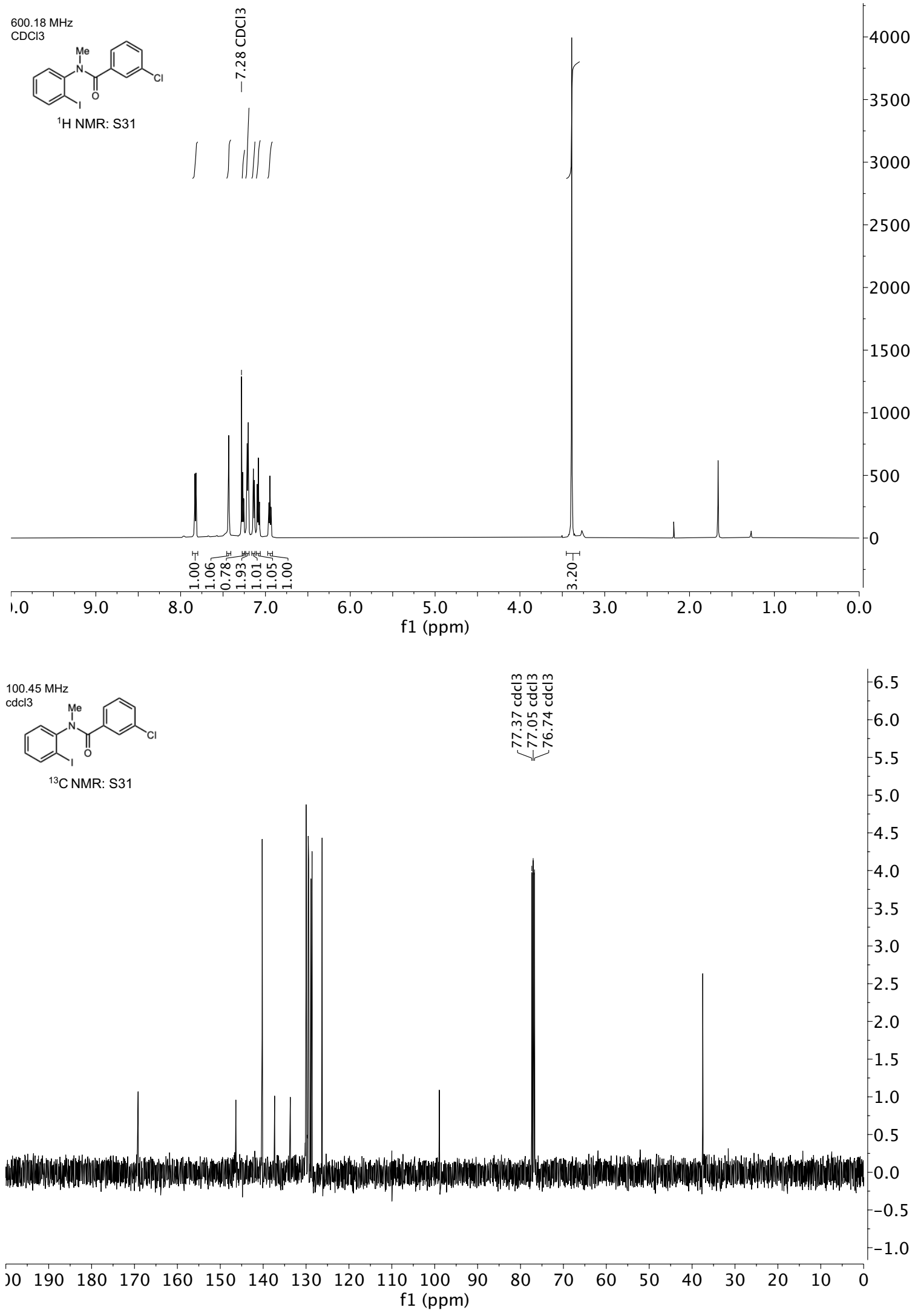



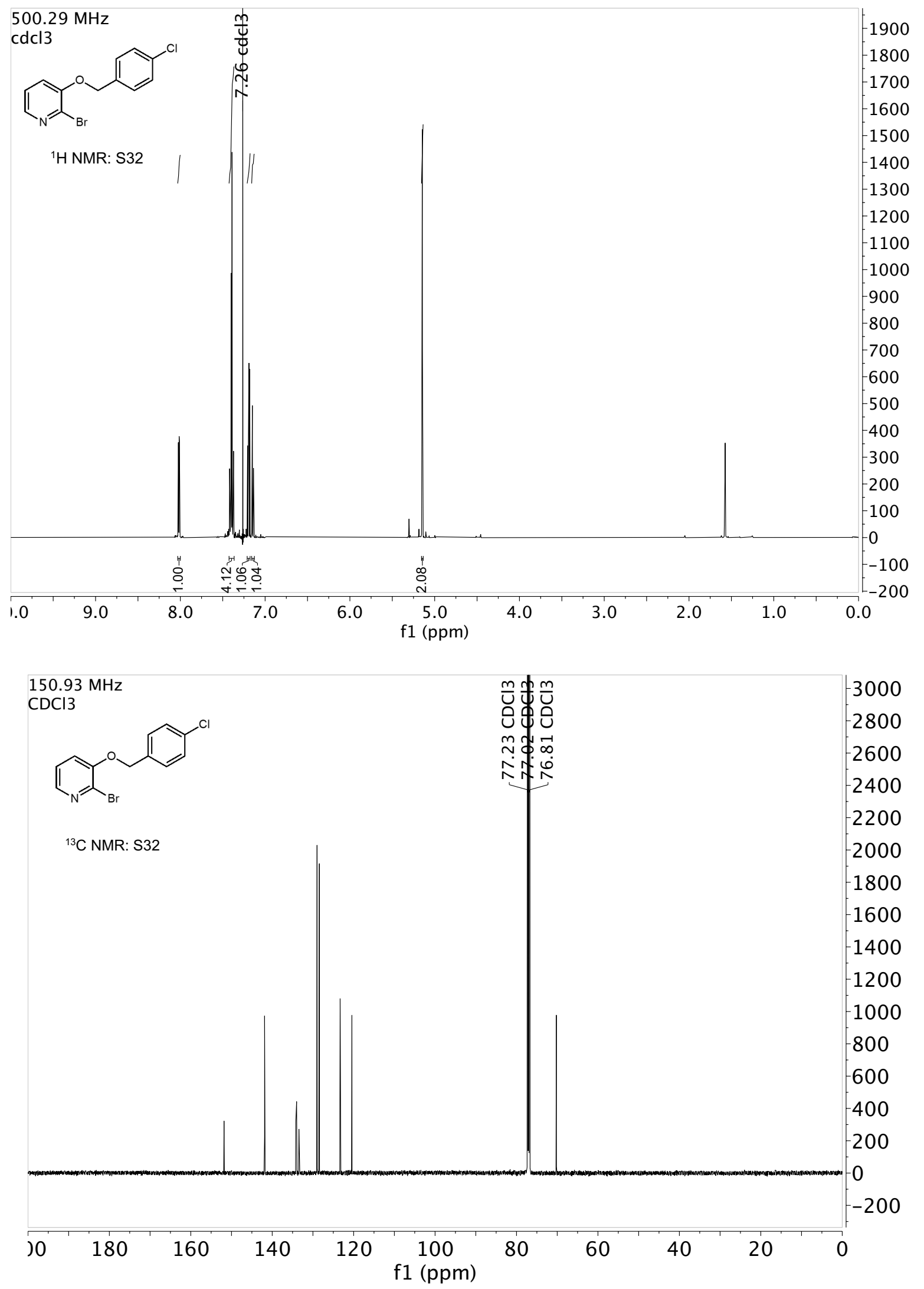

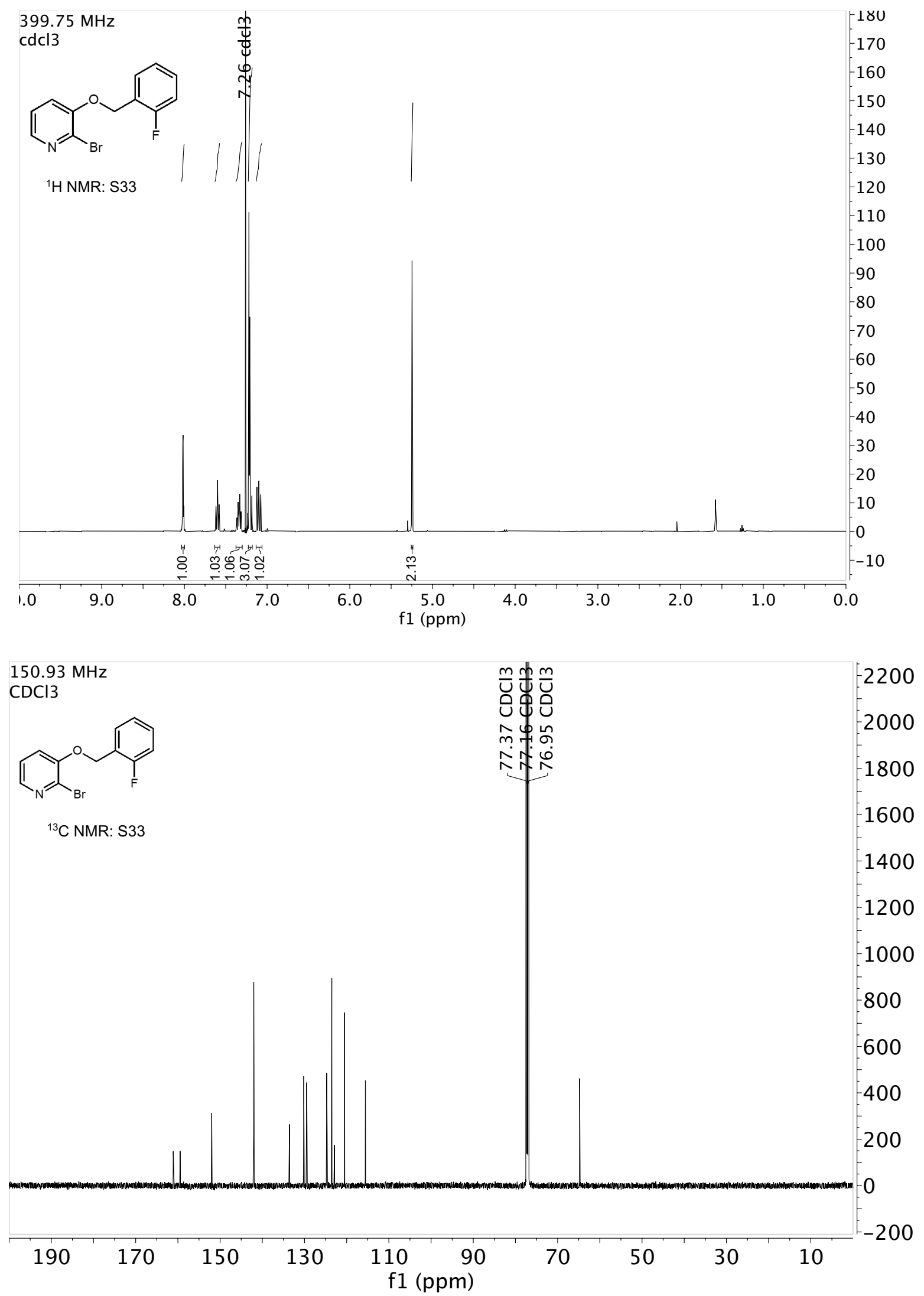


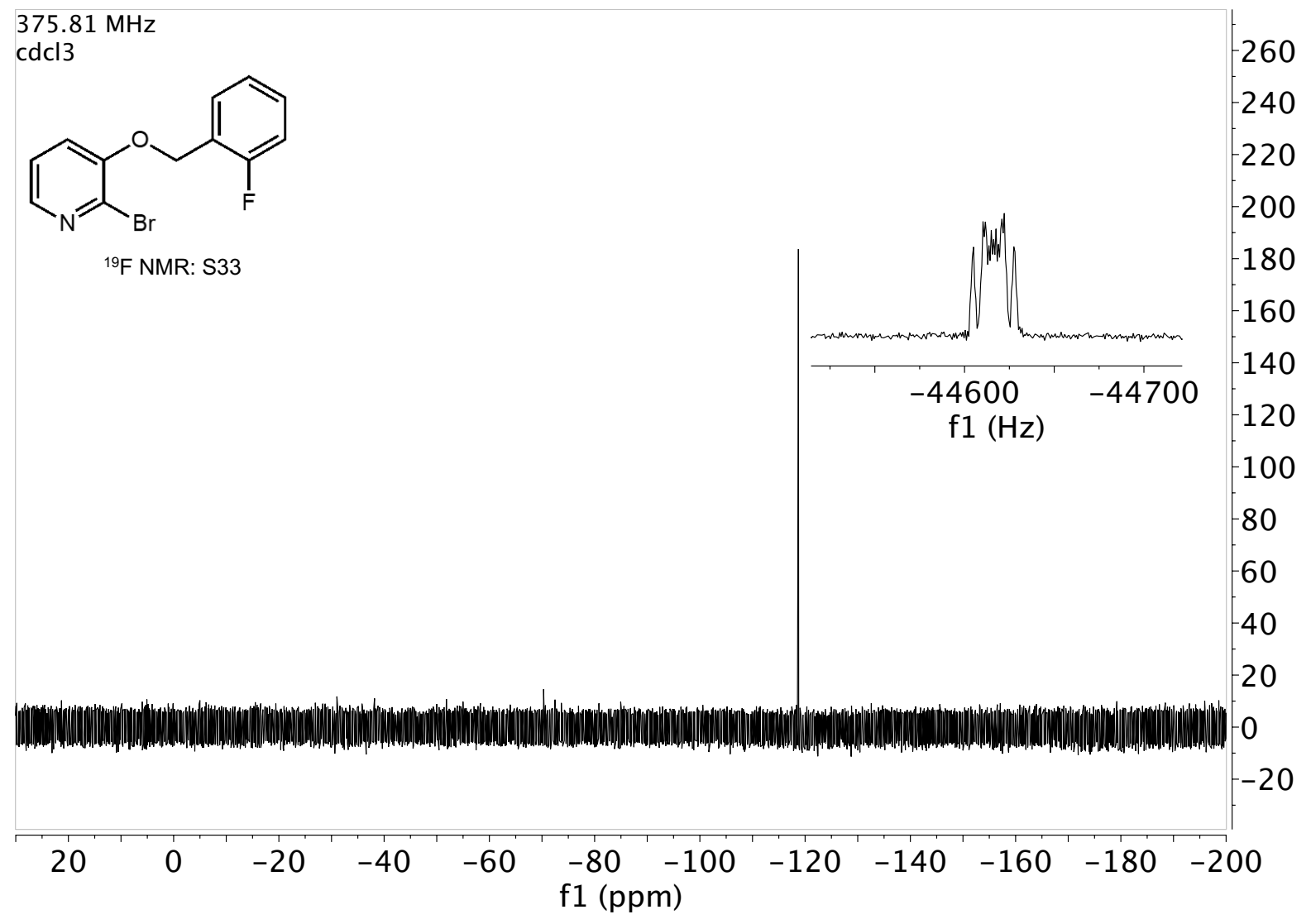



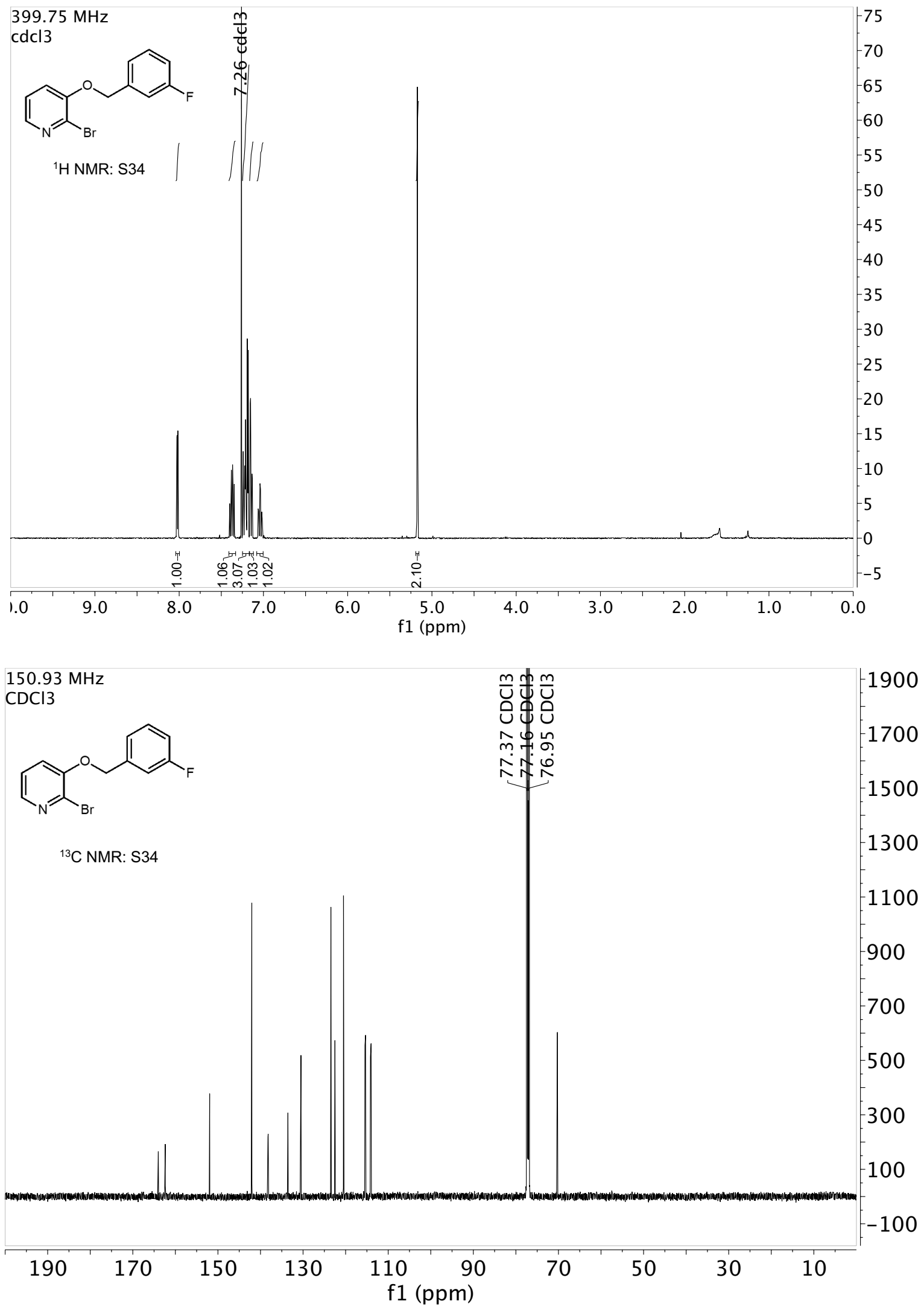


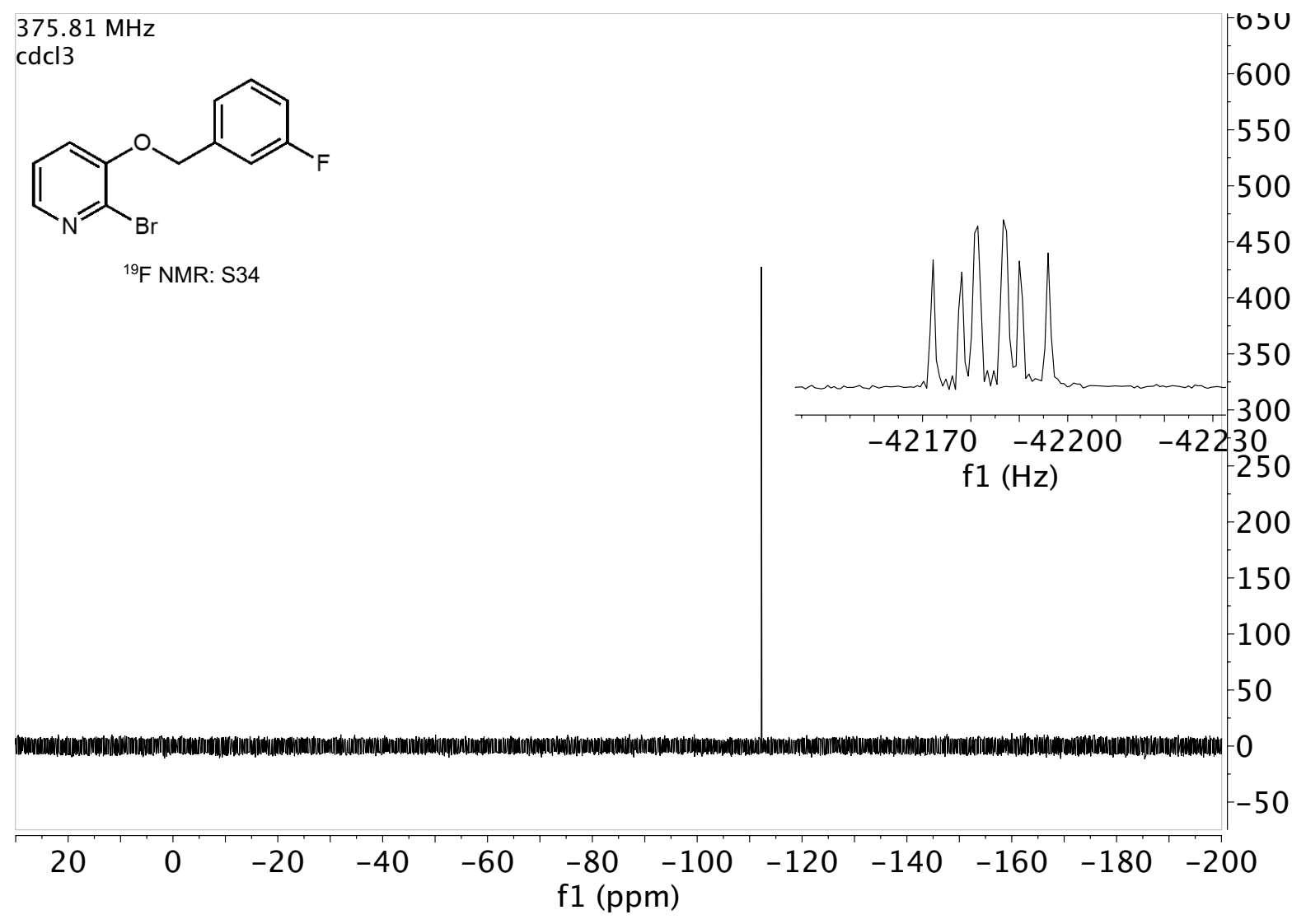



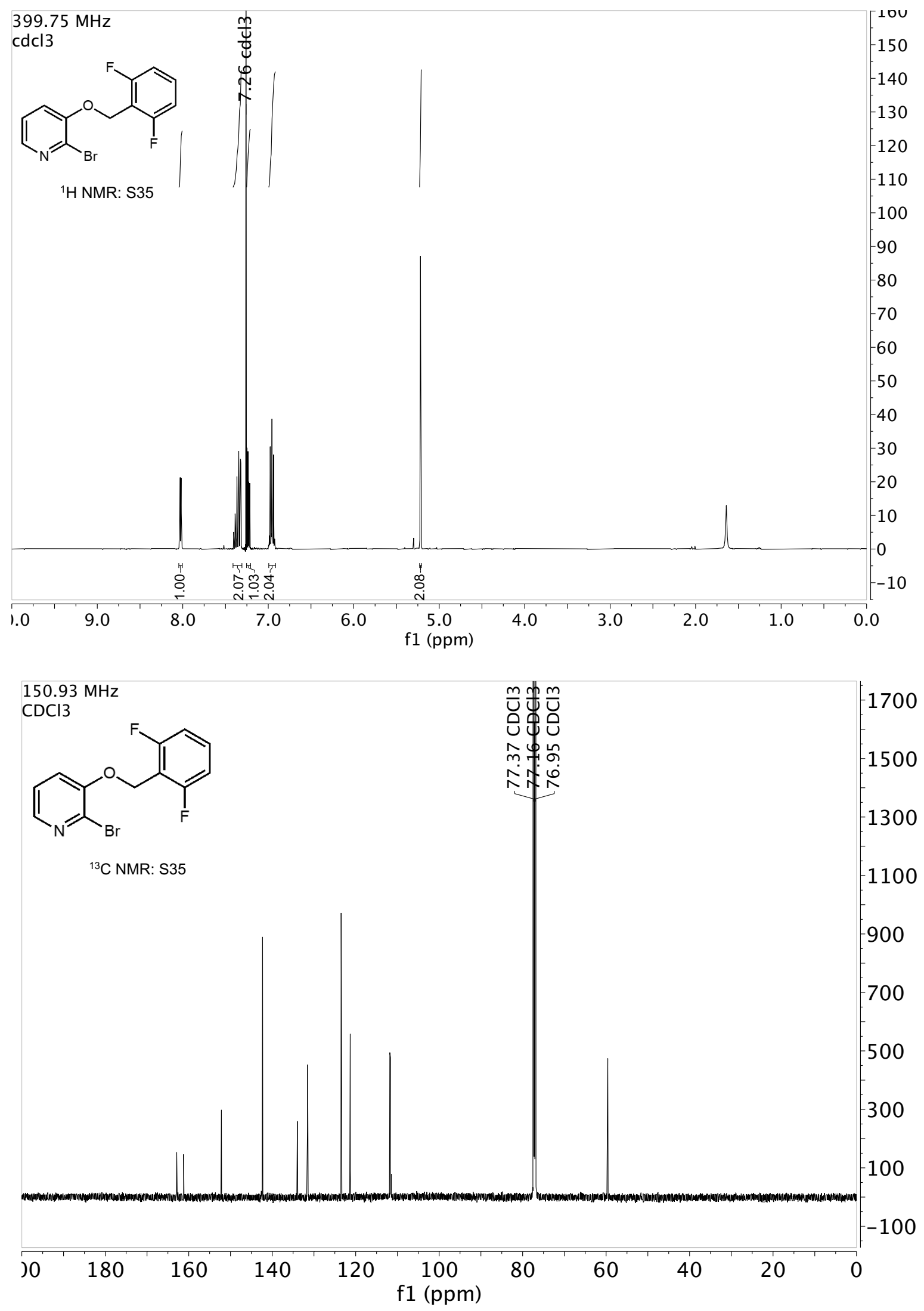


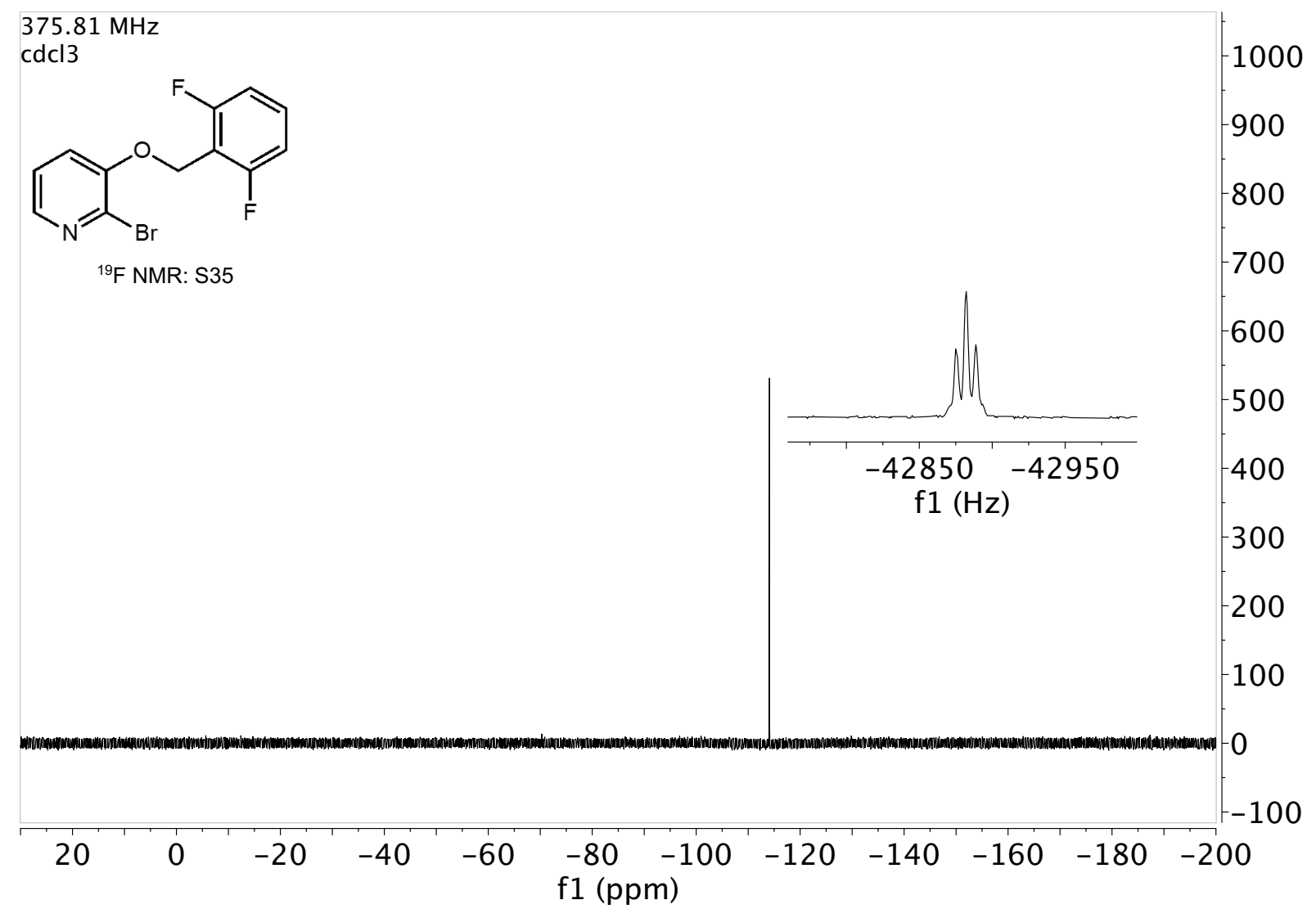




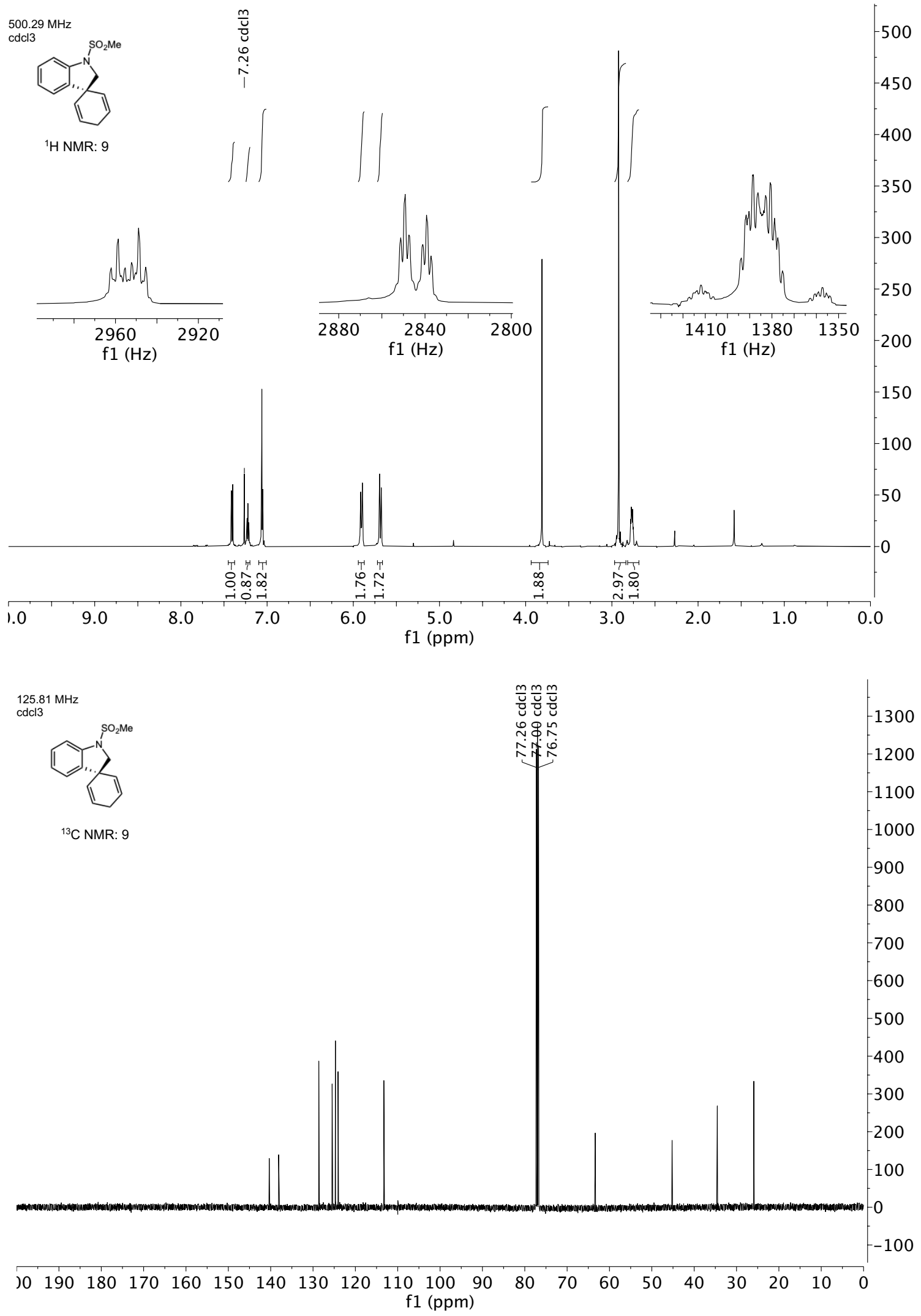




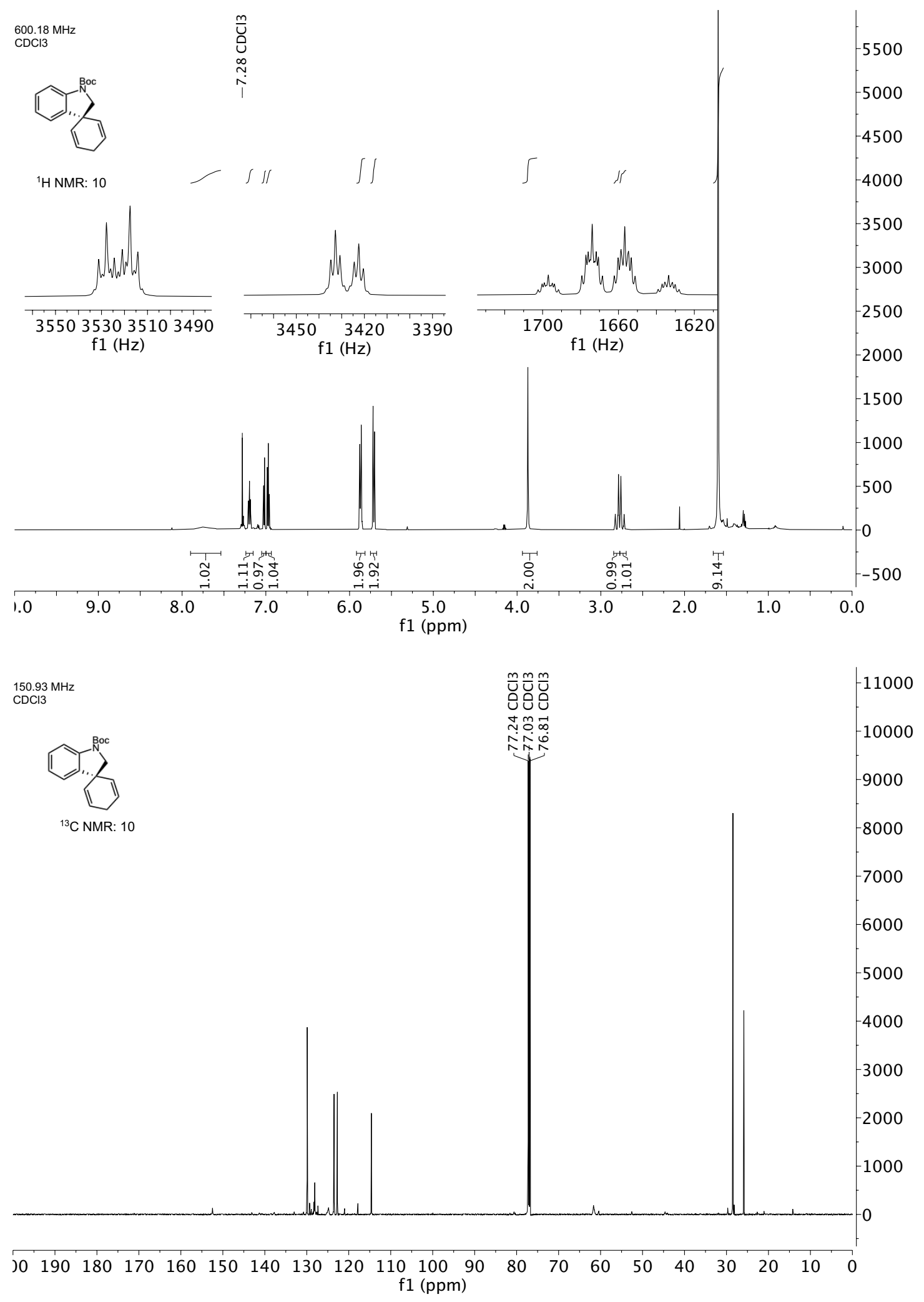




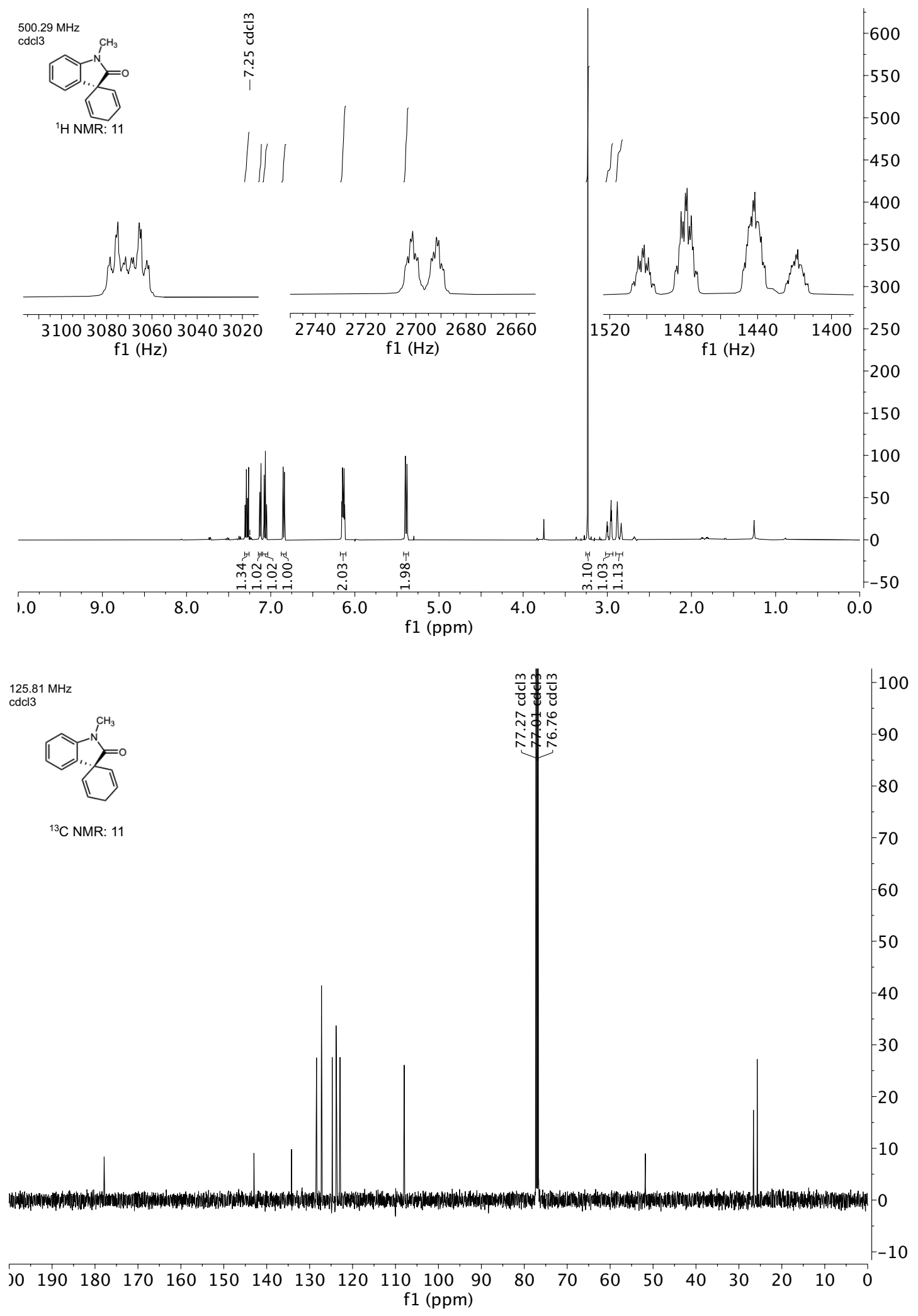




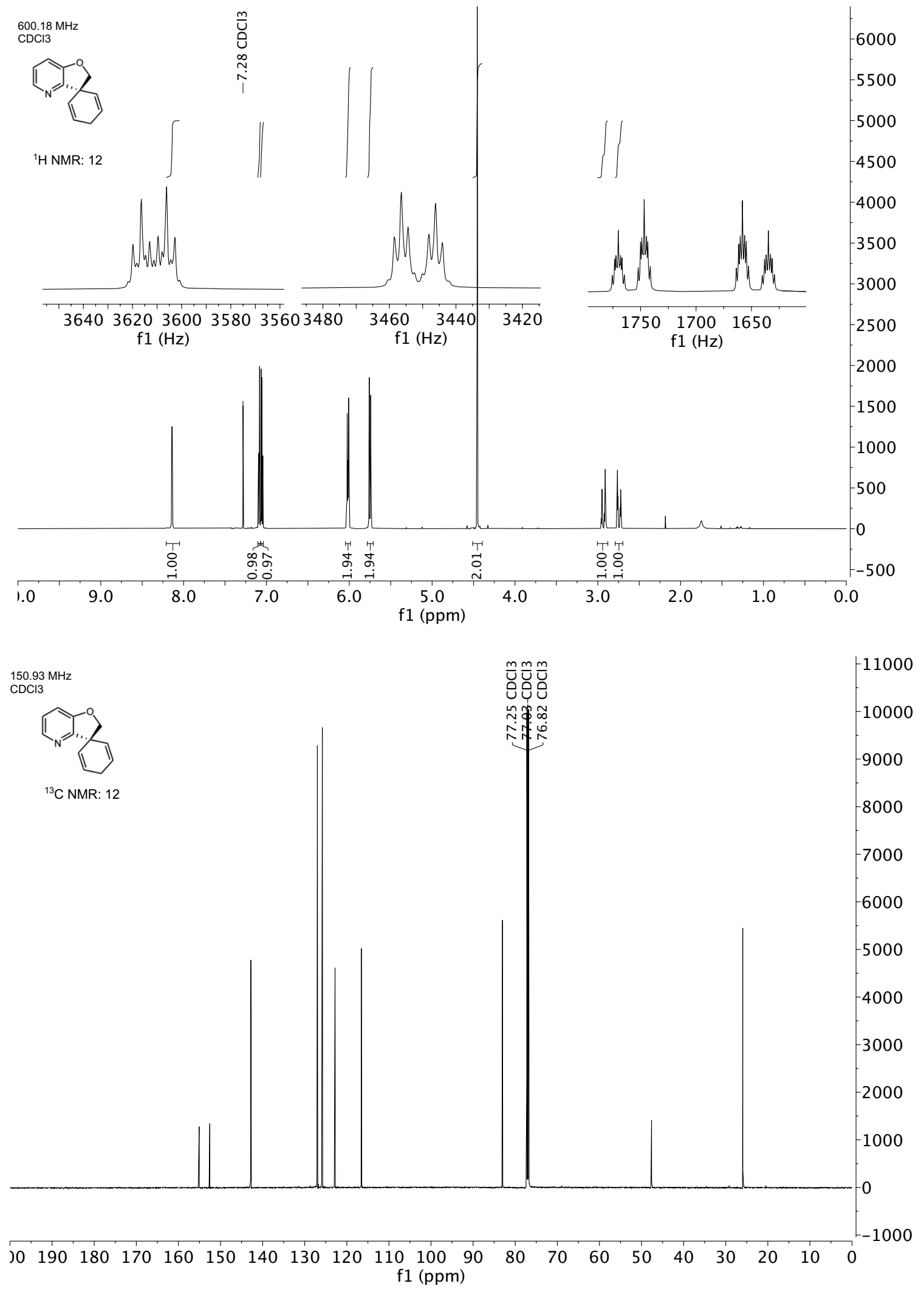




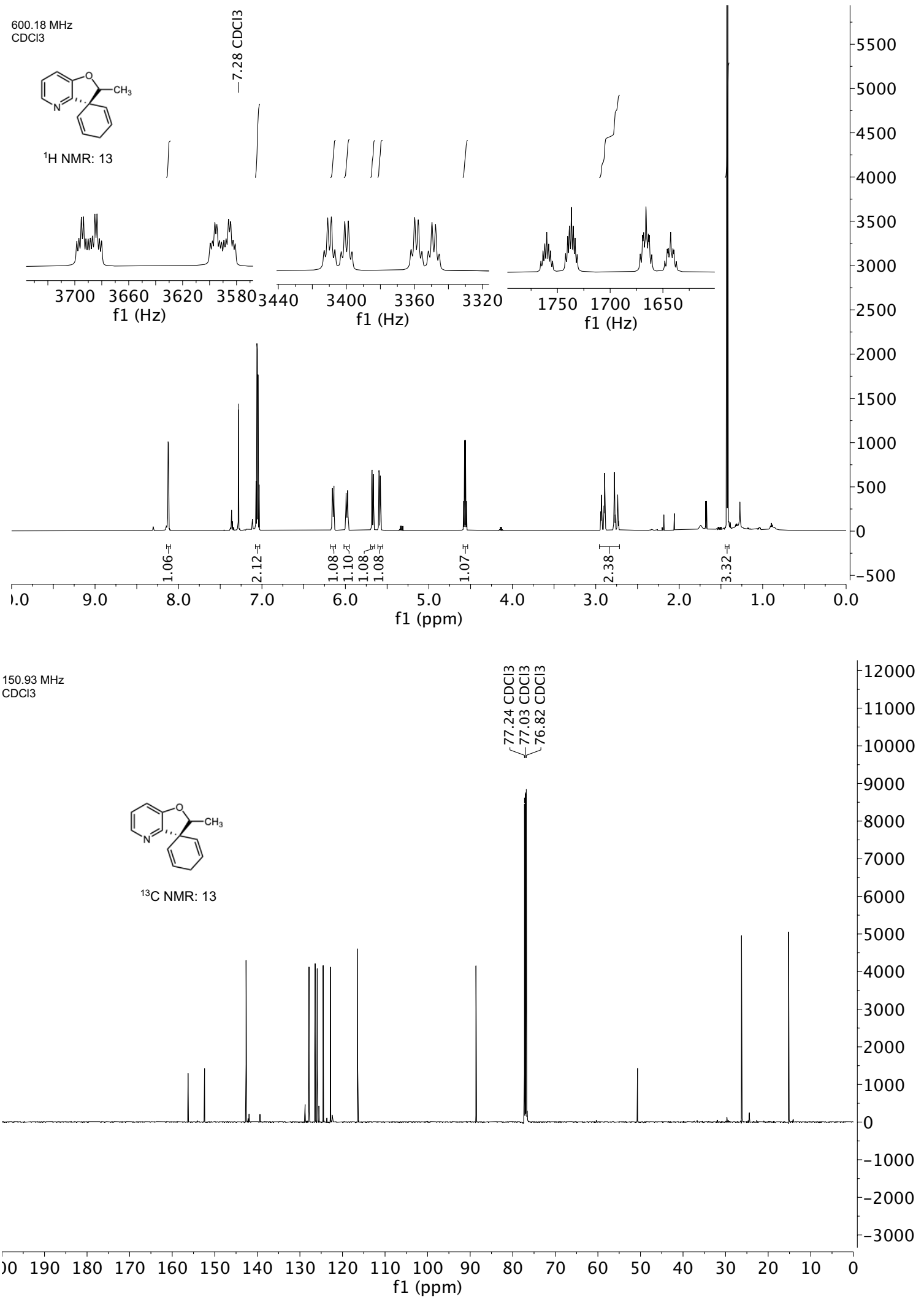




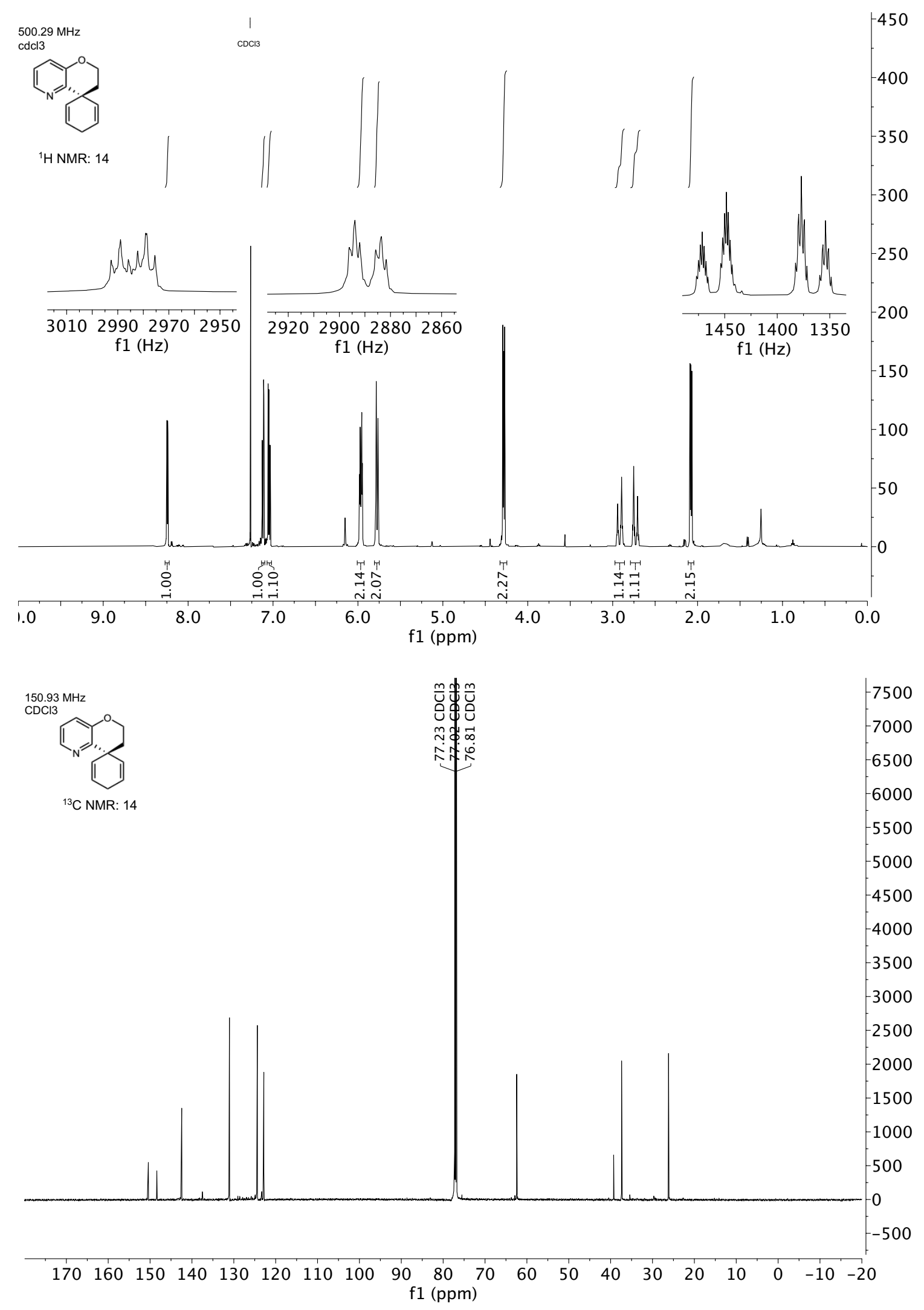



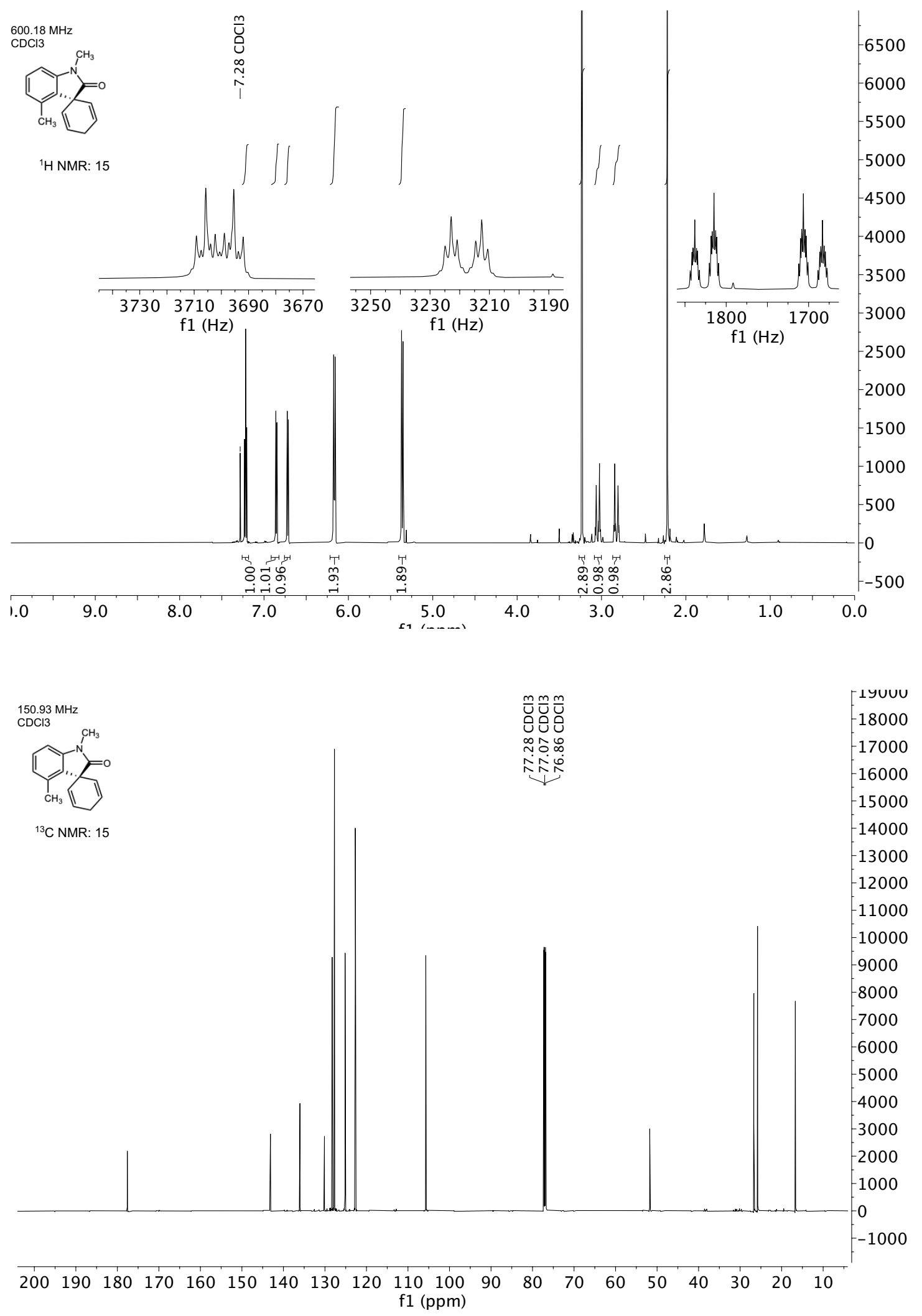

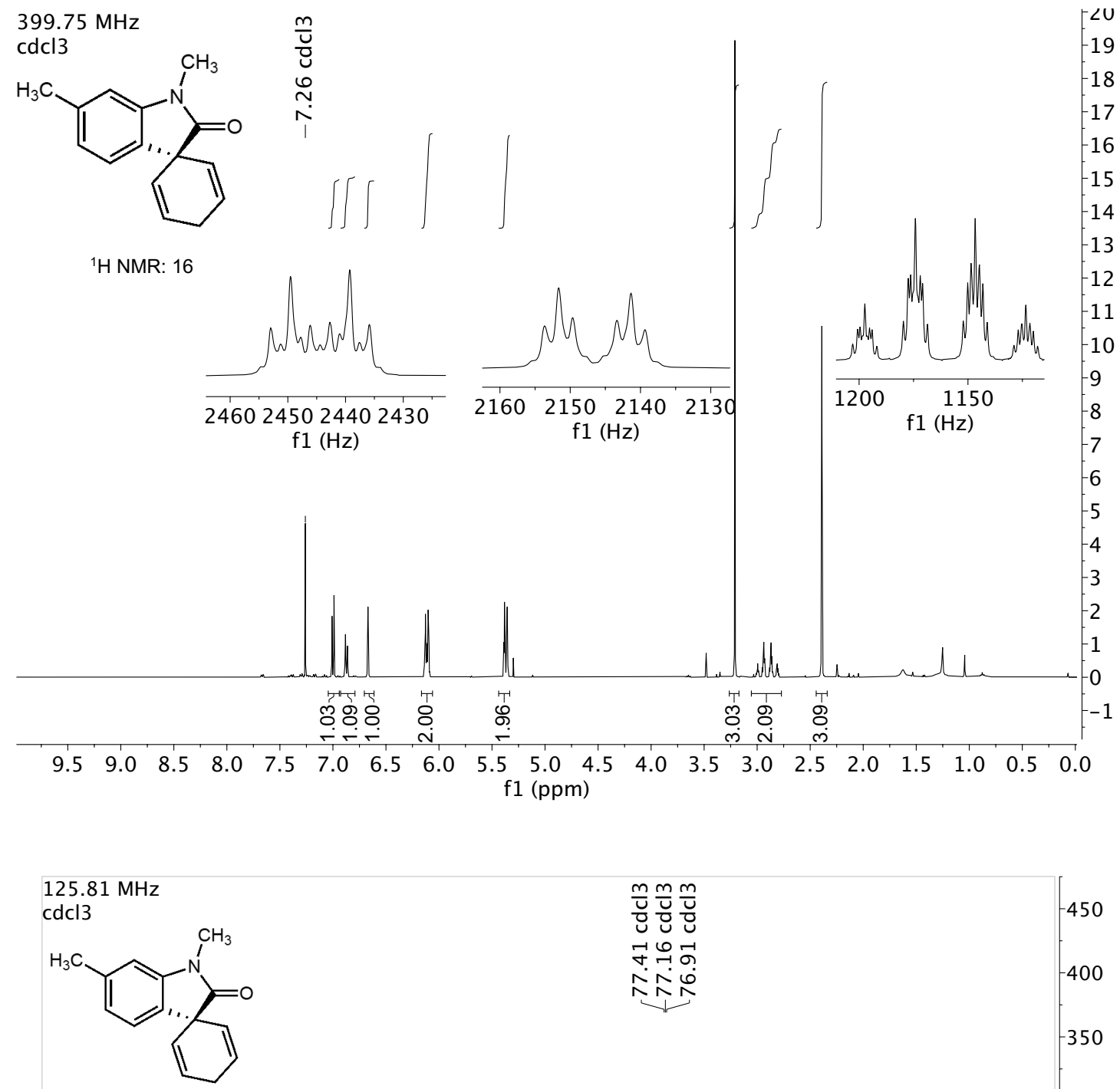

${ }^{13} \mathrm{C}$ NMR: 16

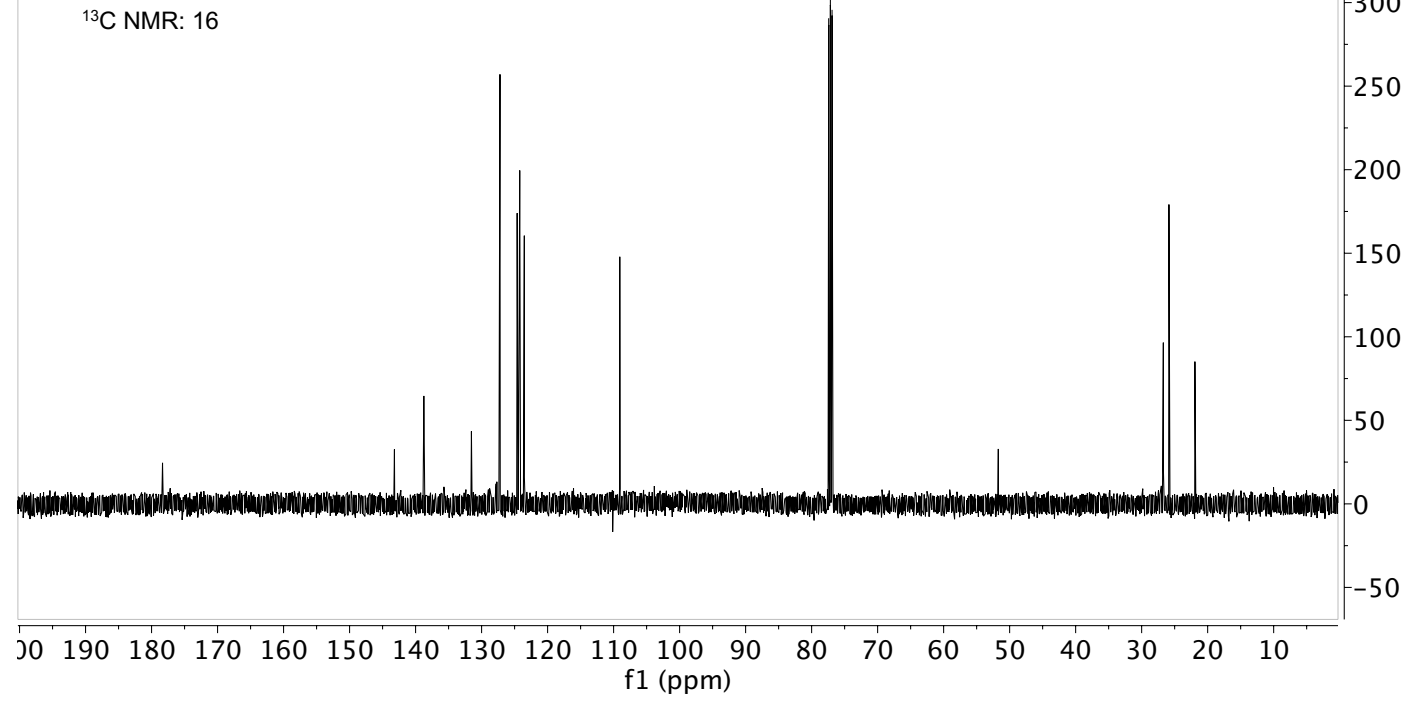




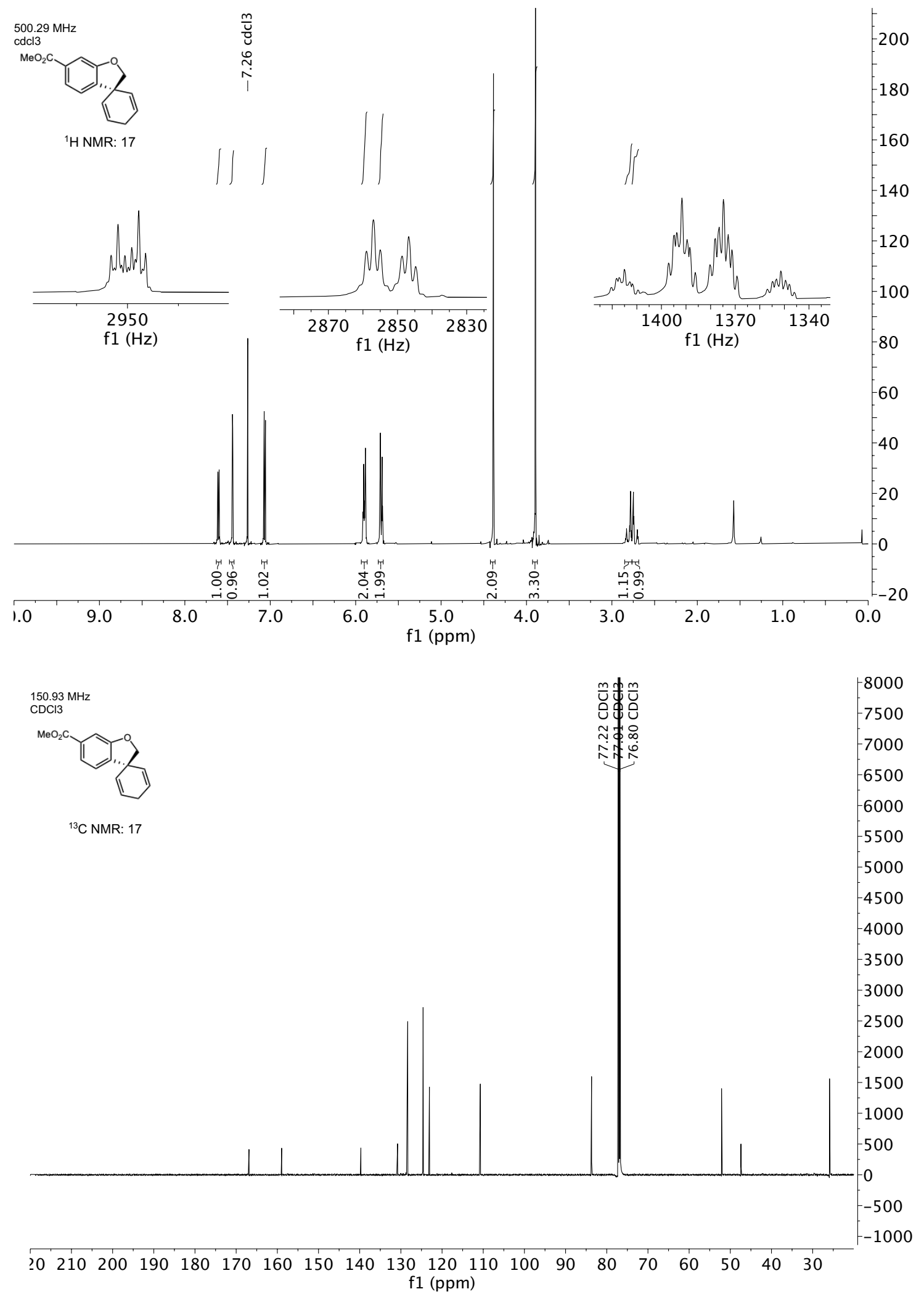




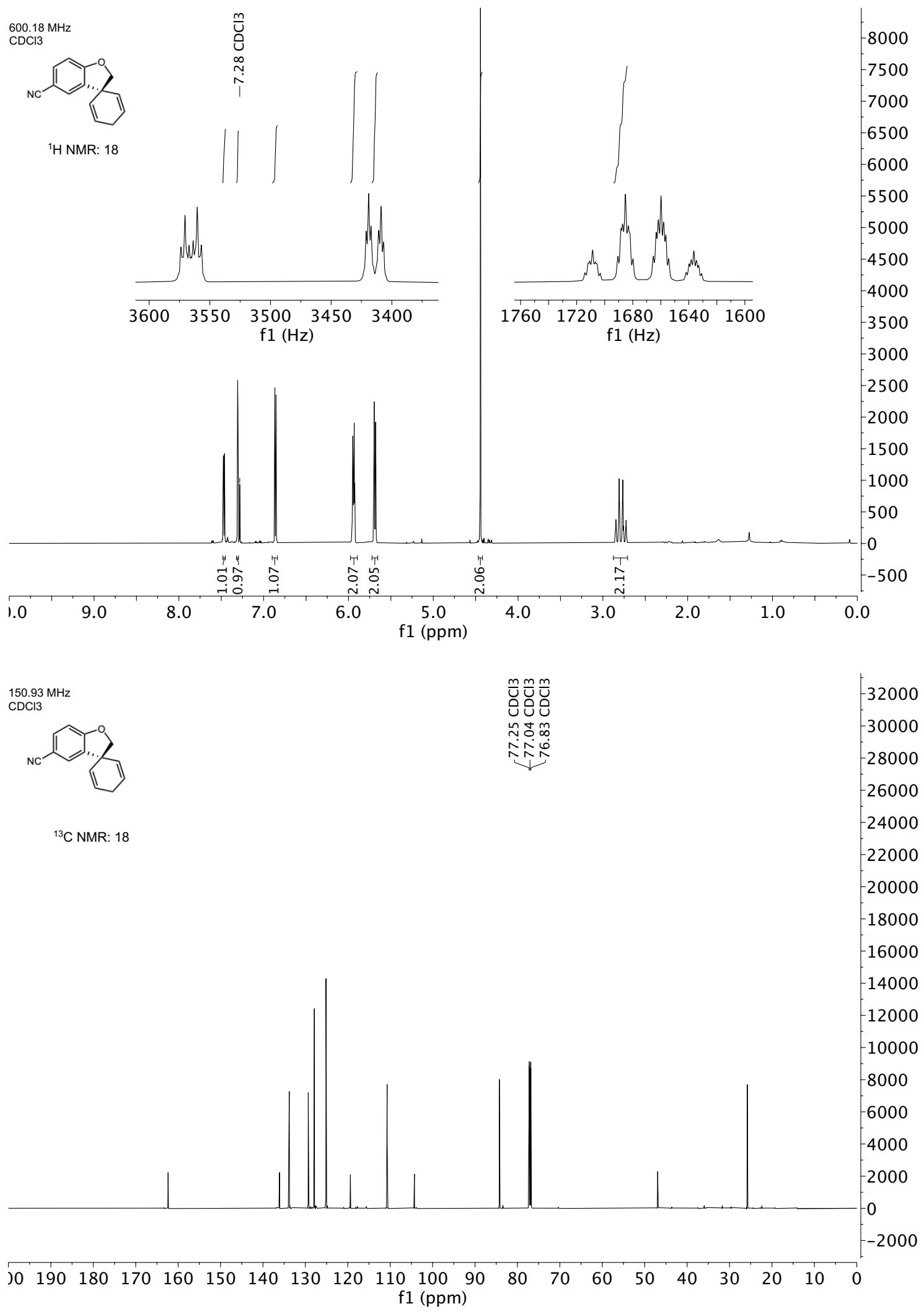




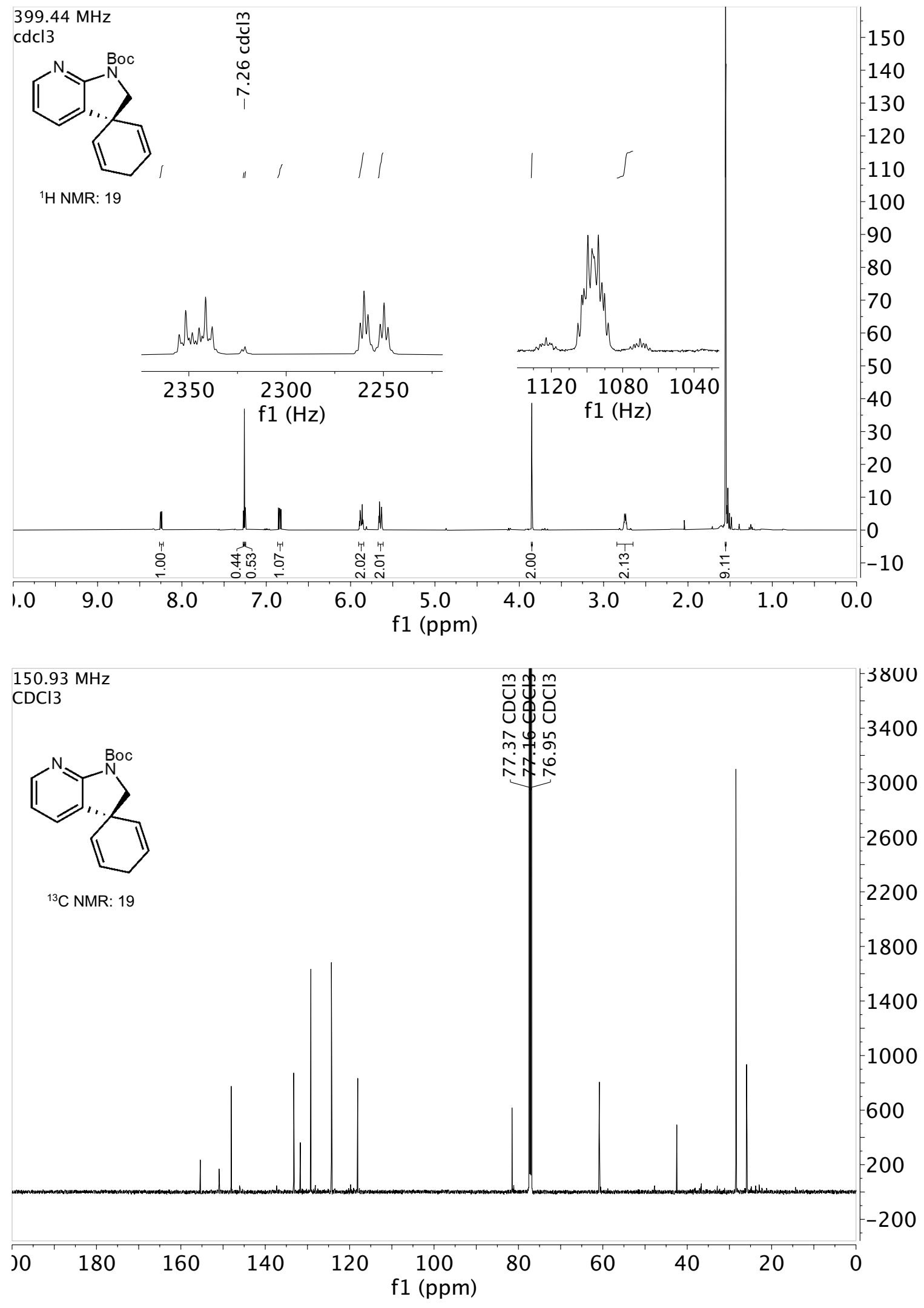




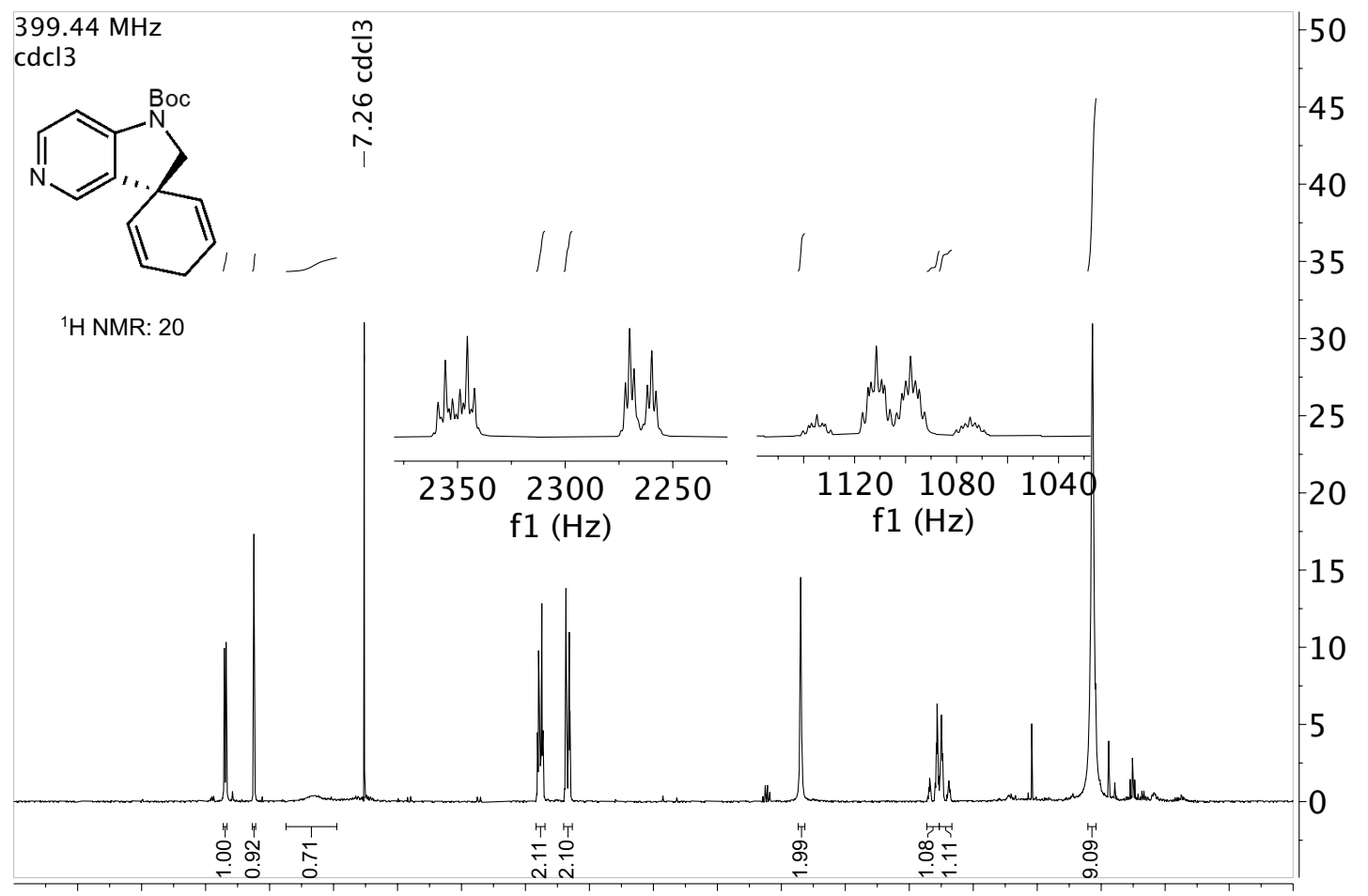

$\begin{array}{llllllllllllllllllllll}9.5 & 9.0 & 8.5 & 8.0 & 7.5 & 7.0 & 6.5 & 6.0 & 5.5 & 5.0 & 4.5 & 4.0 & 3.5 & 3.0 & 2.5 & 2.0 & 1.5 & 1.0 & 0.5 & 0.0\end{array}$ $\mathrm{f1}(\mathrm{ppm})$

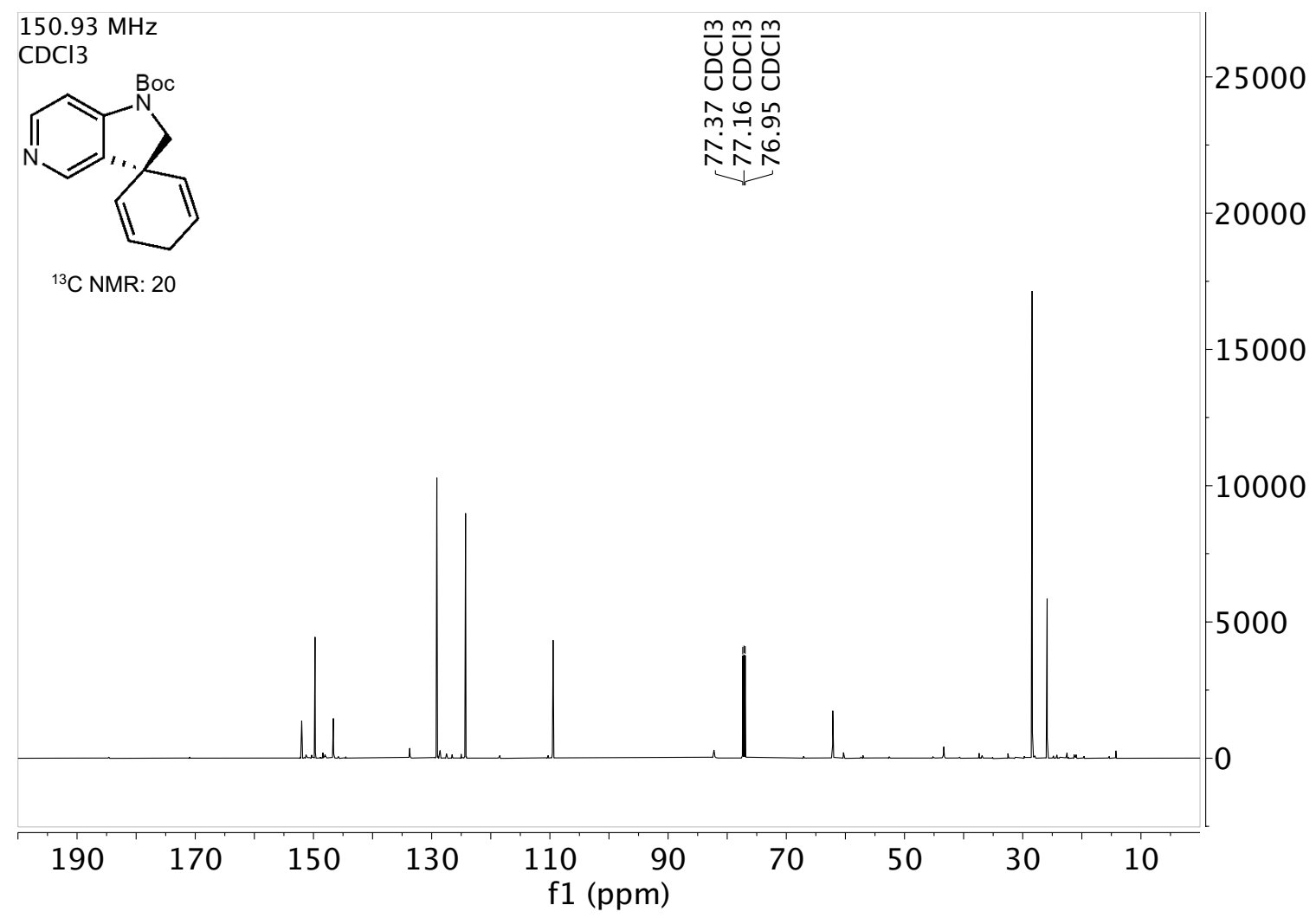




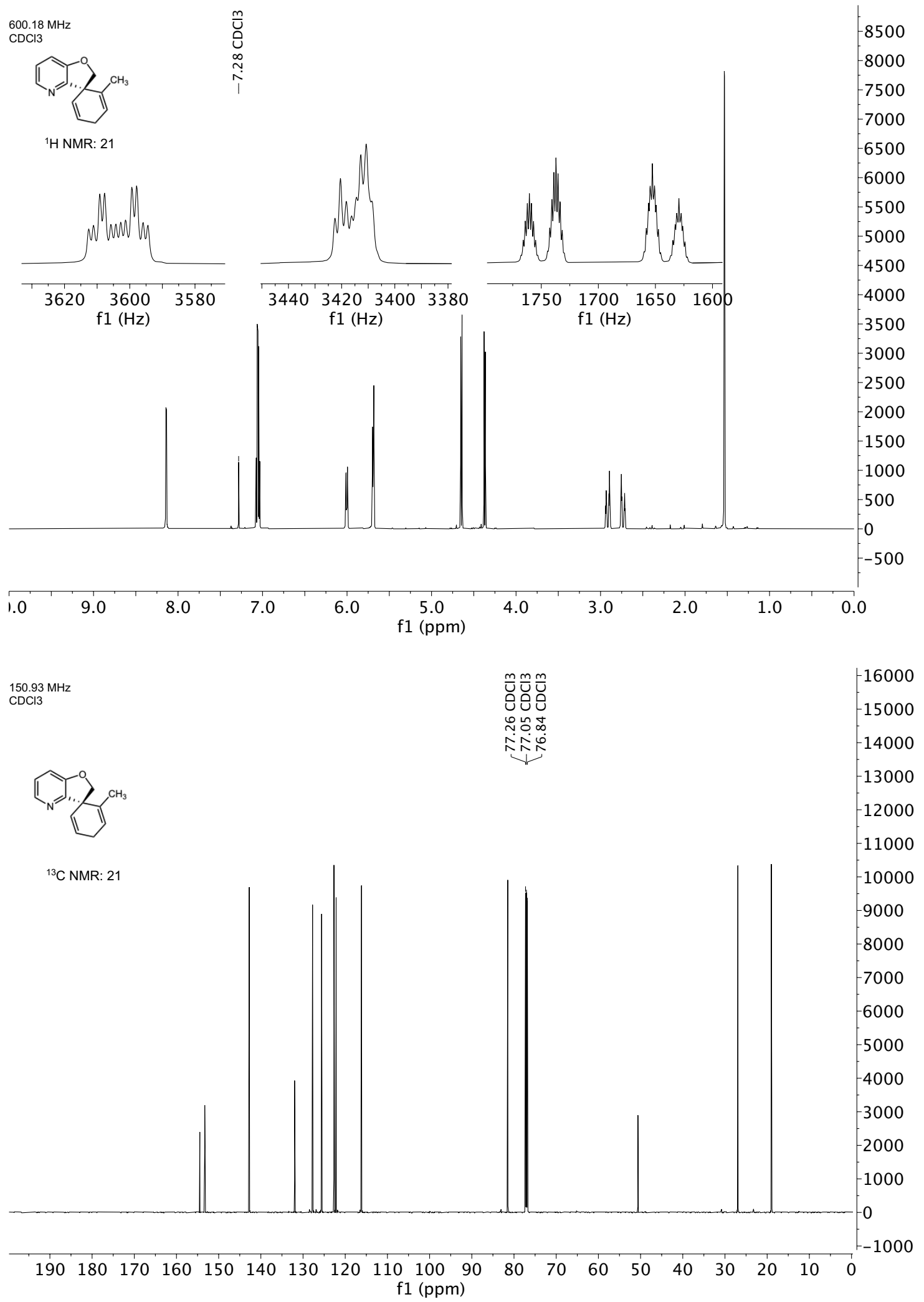




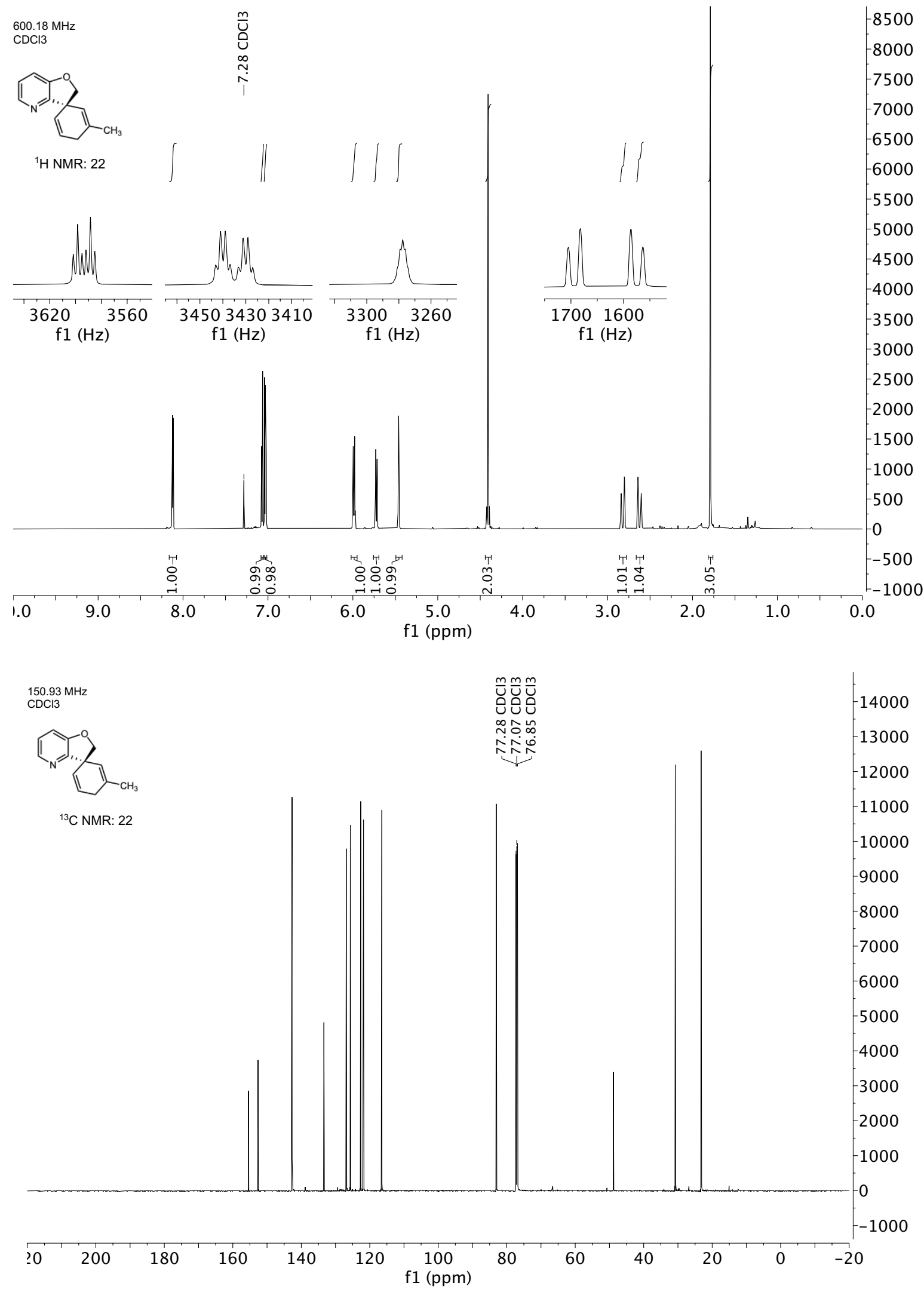




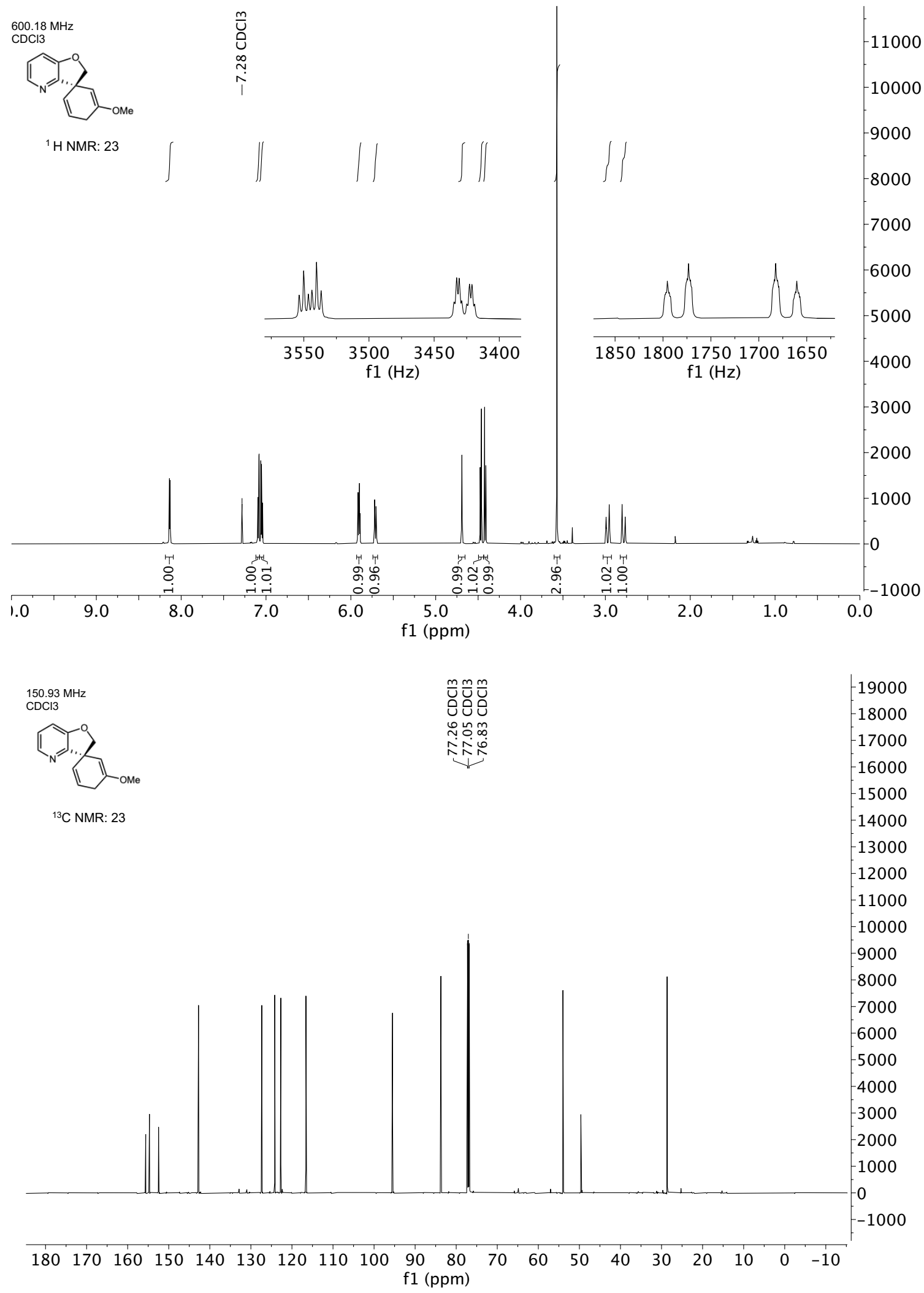



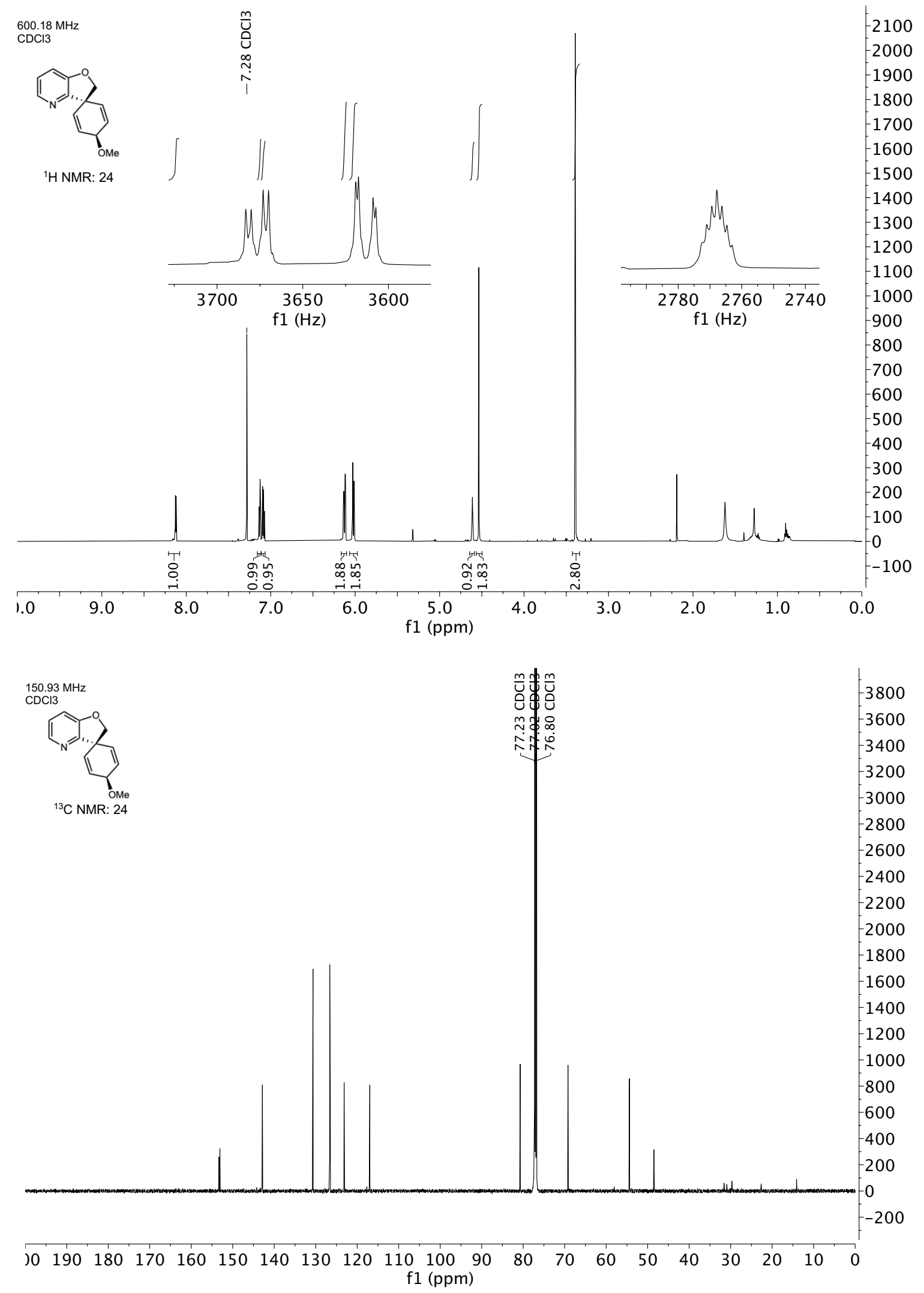

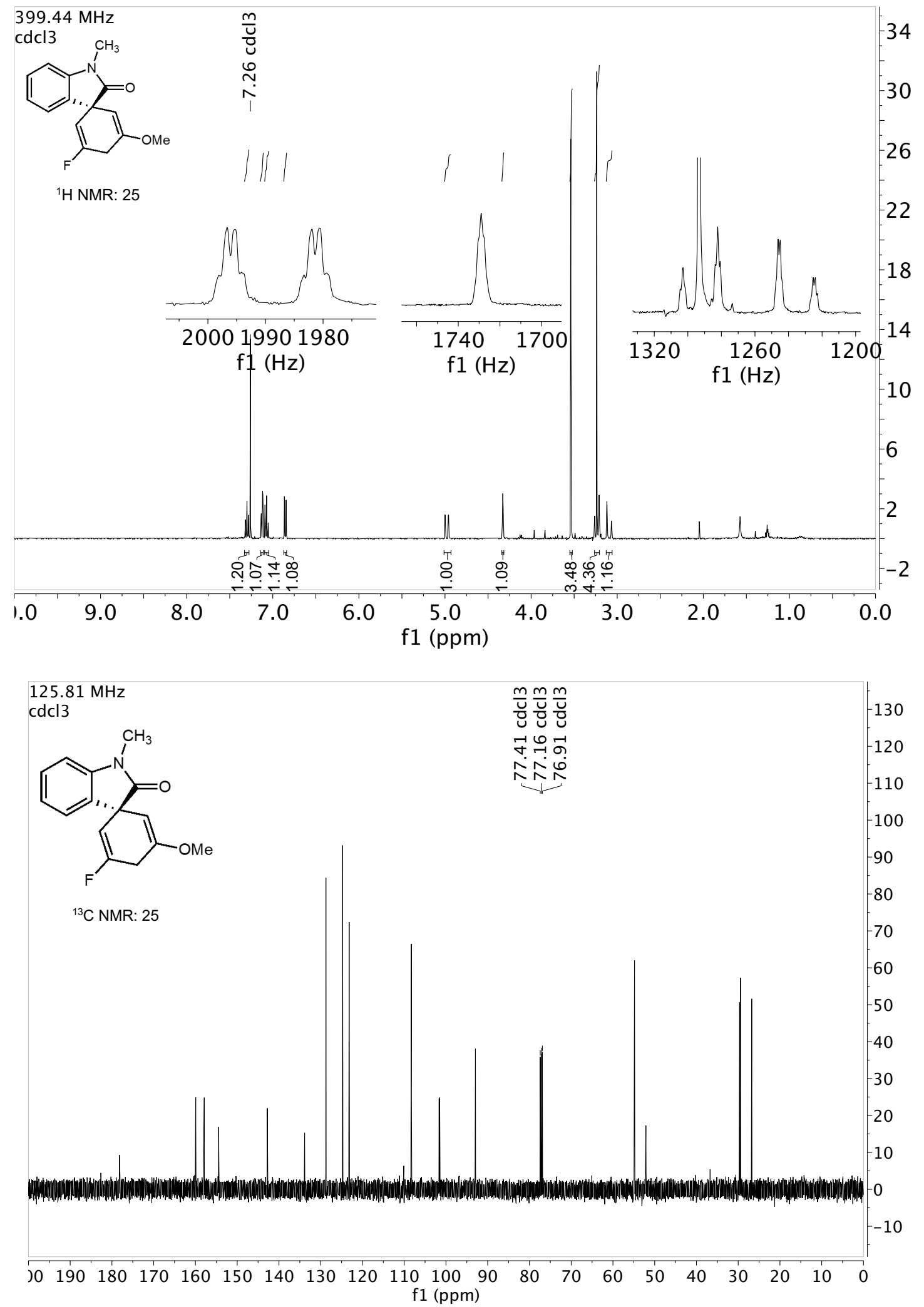


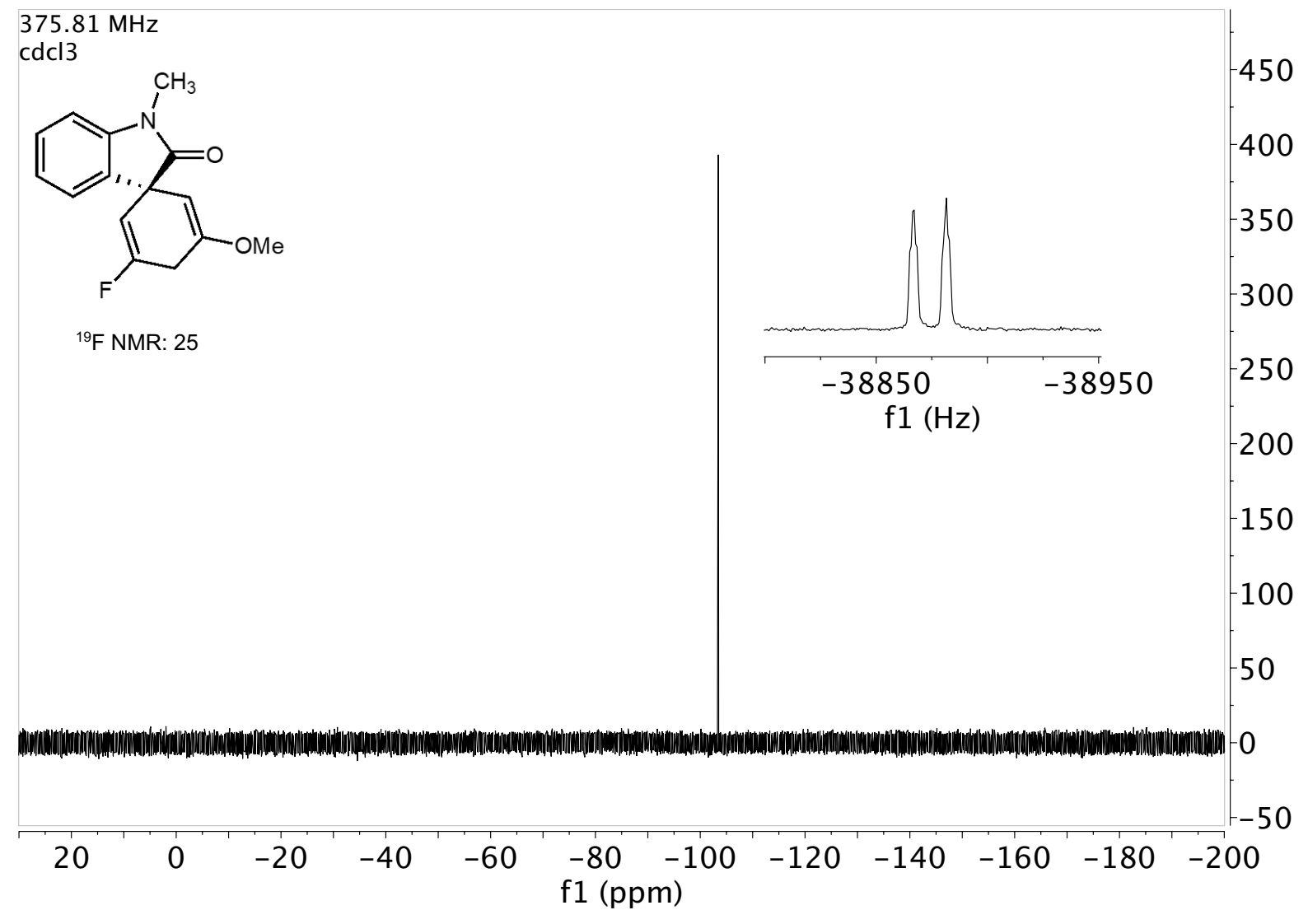



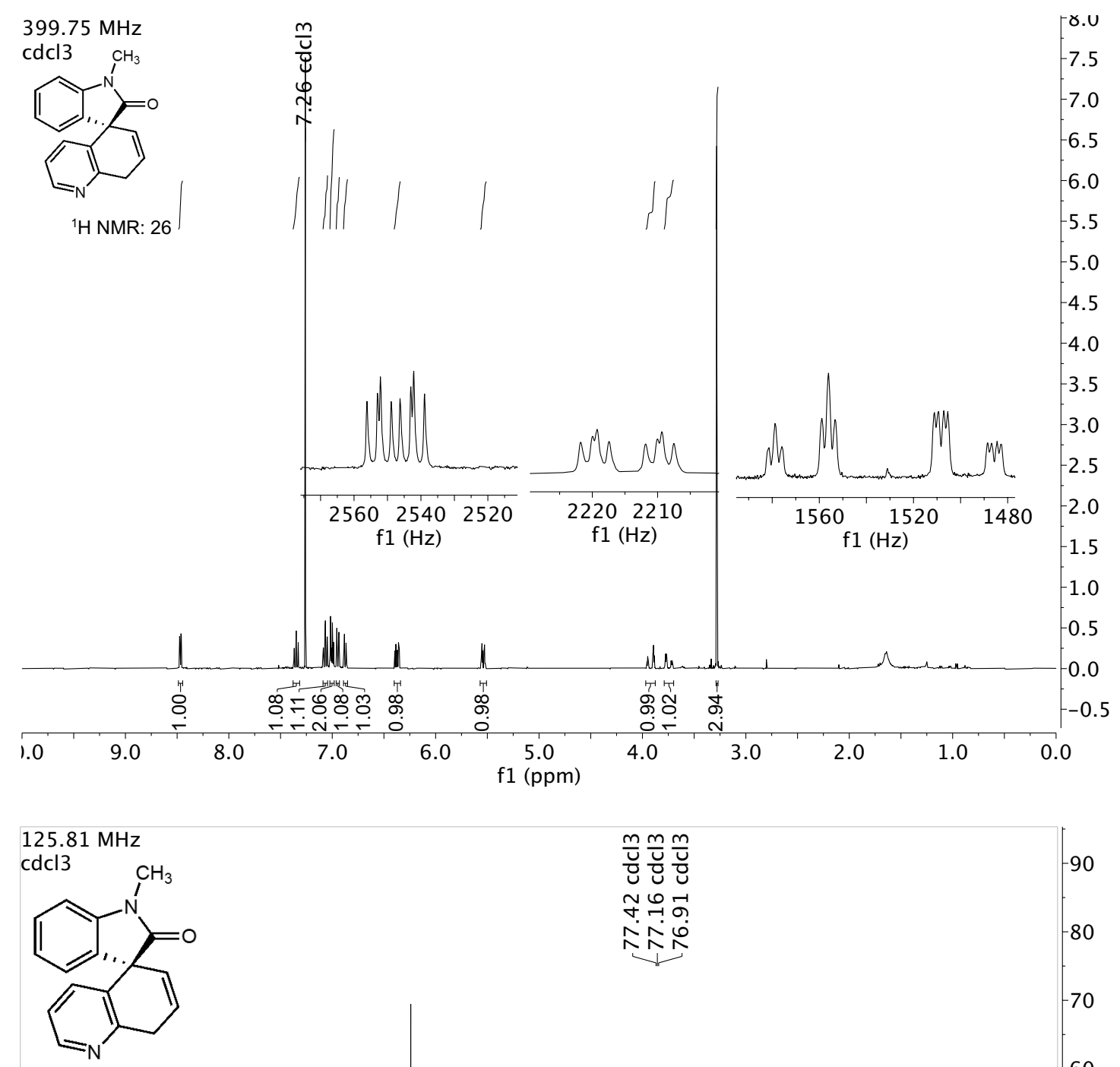

${ }^{13} \mathrm{C}$ NMR: 26

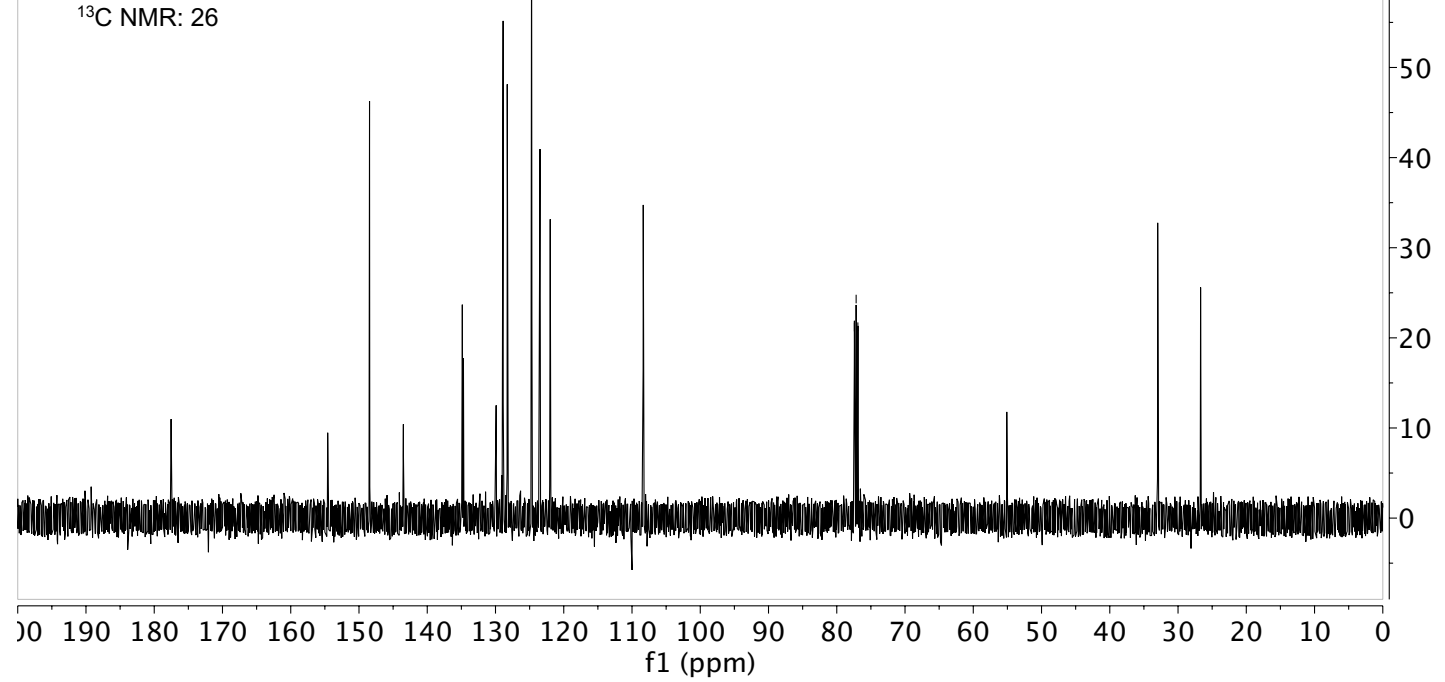




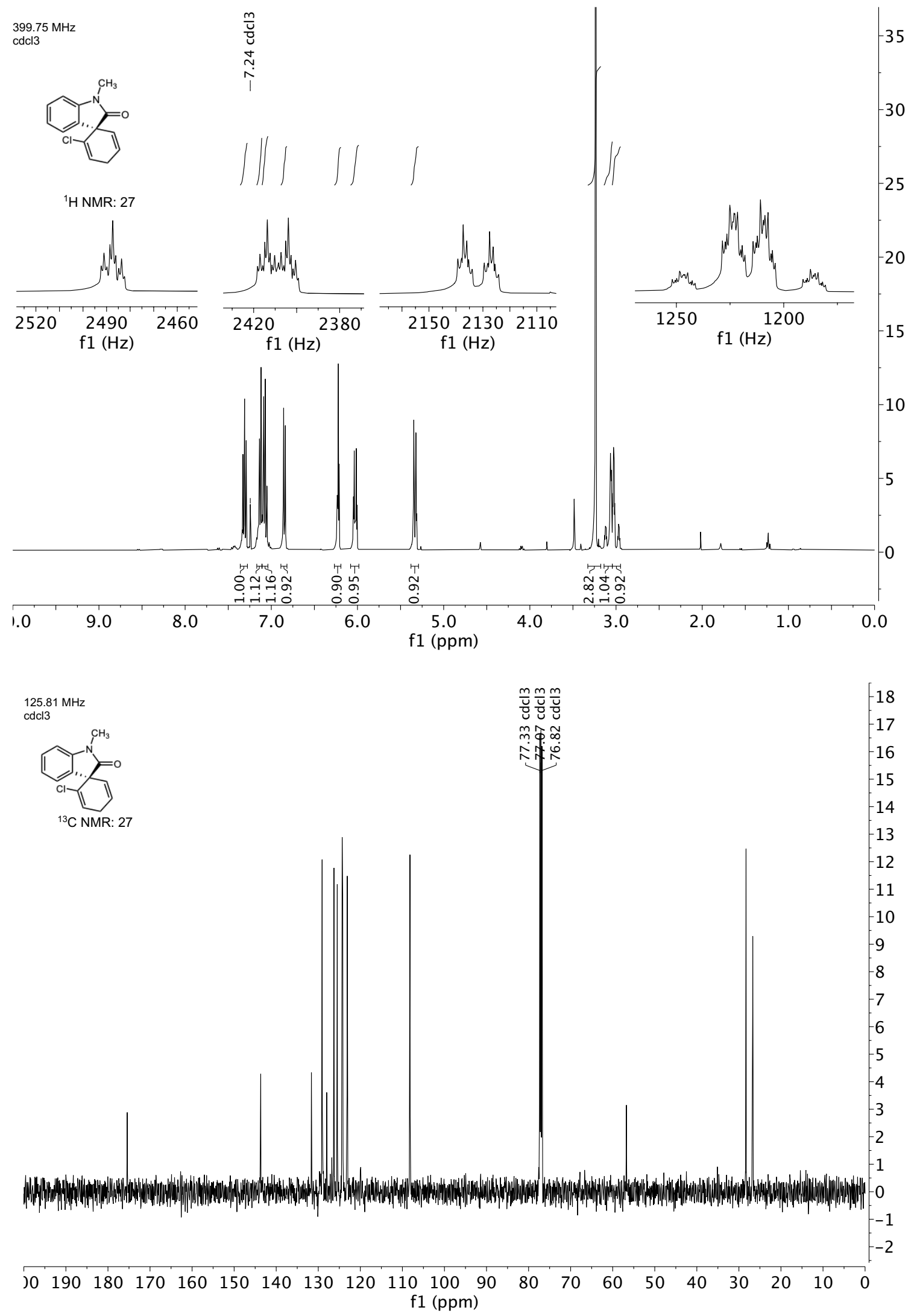



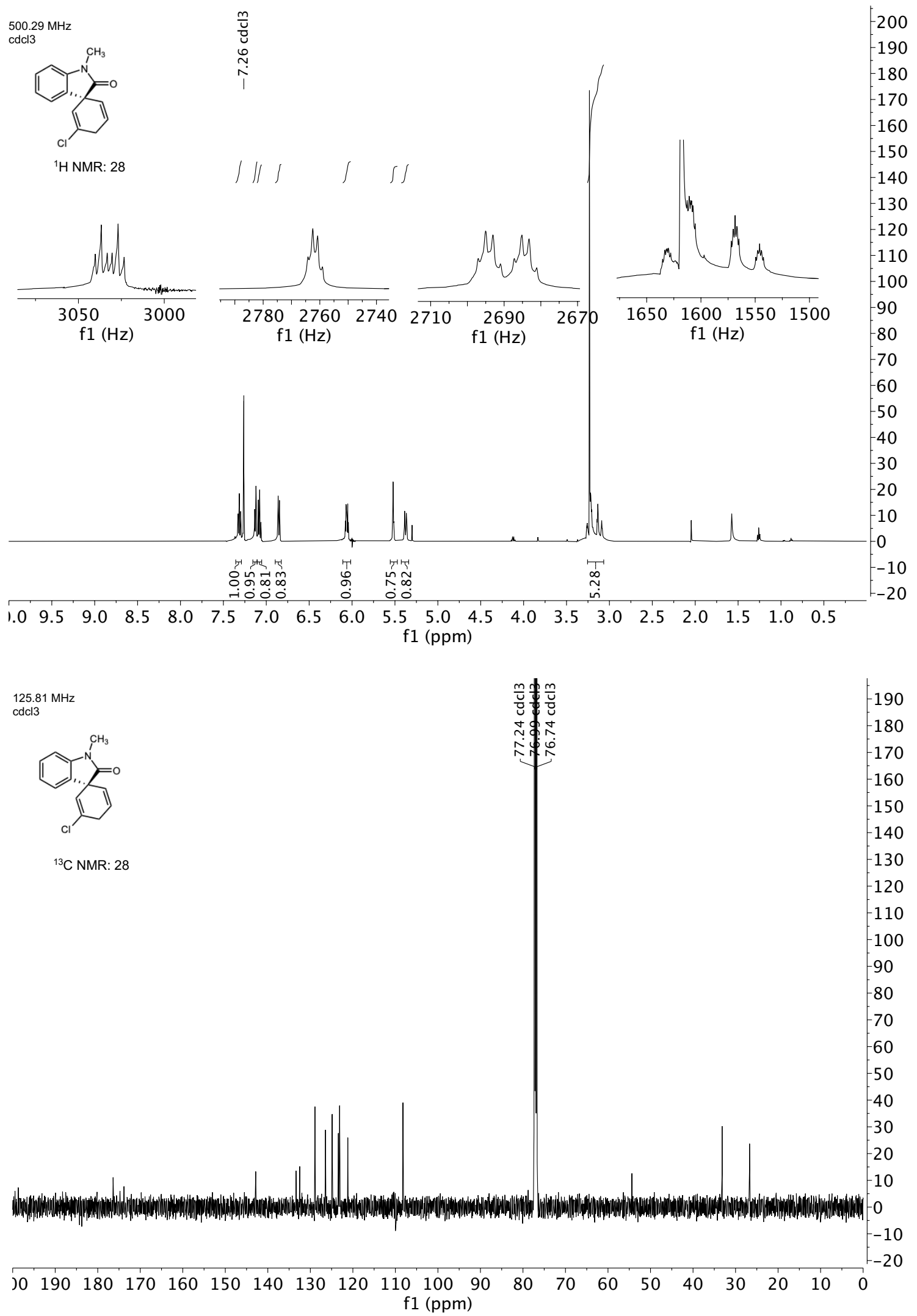


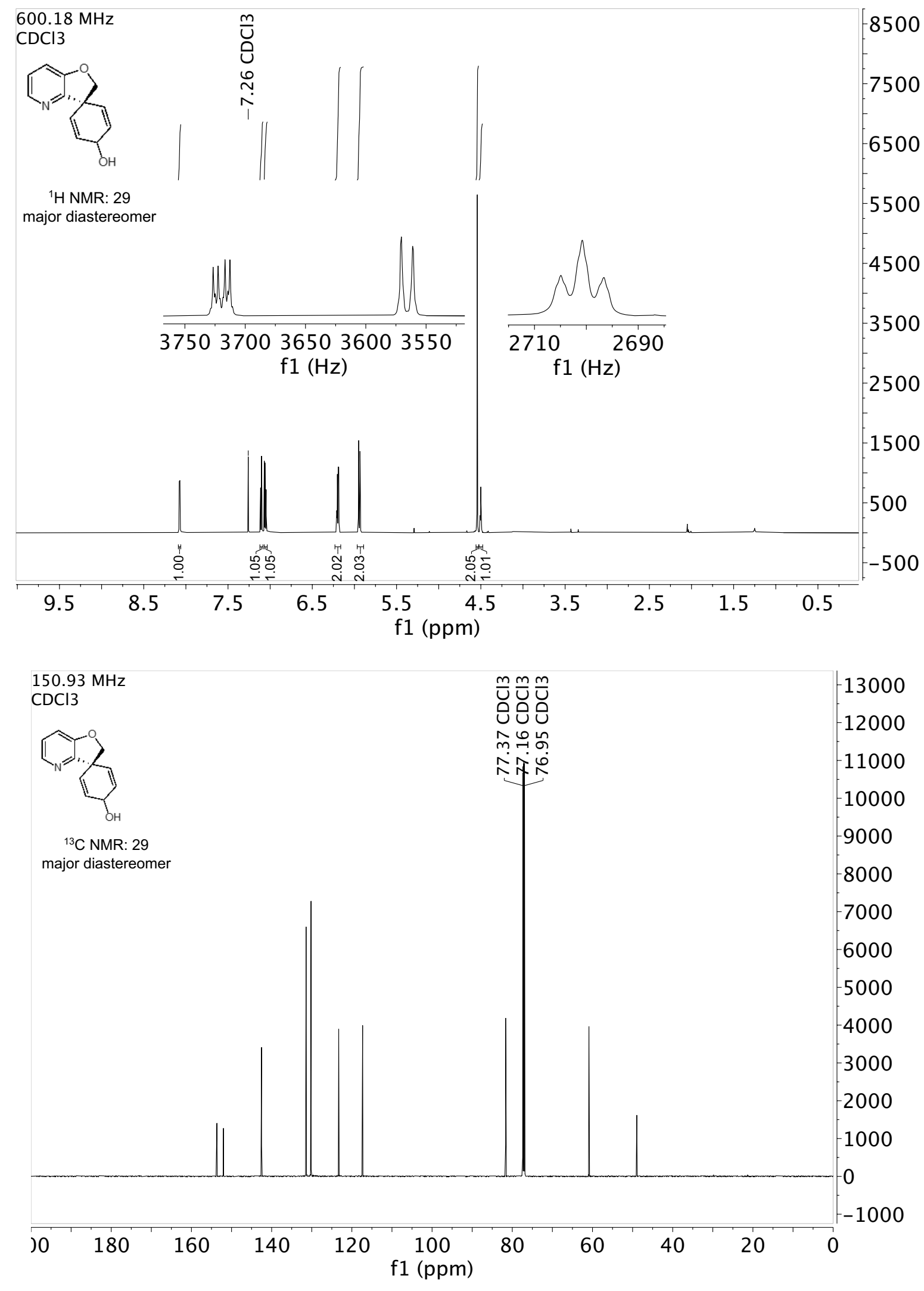



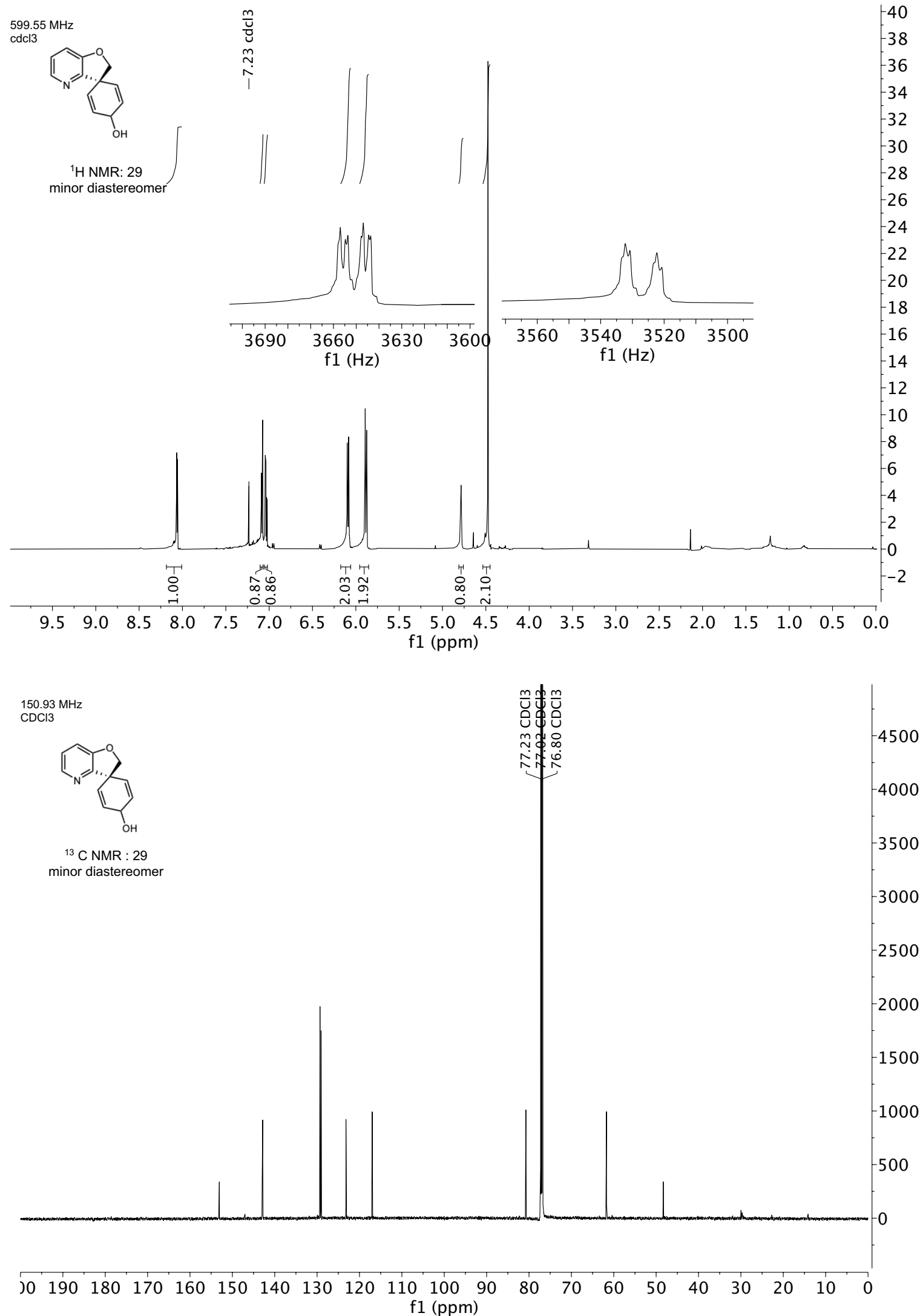


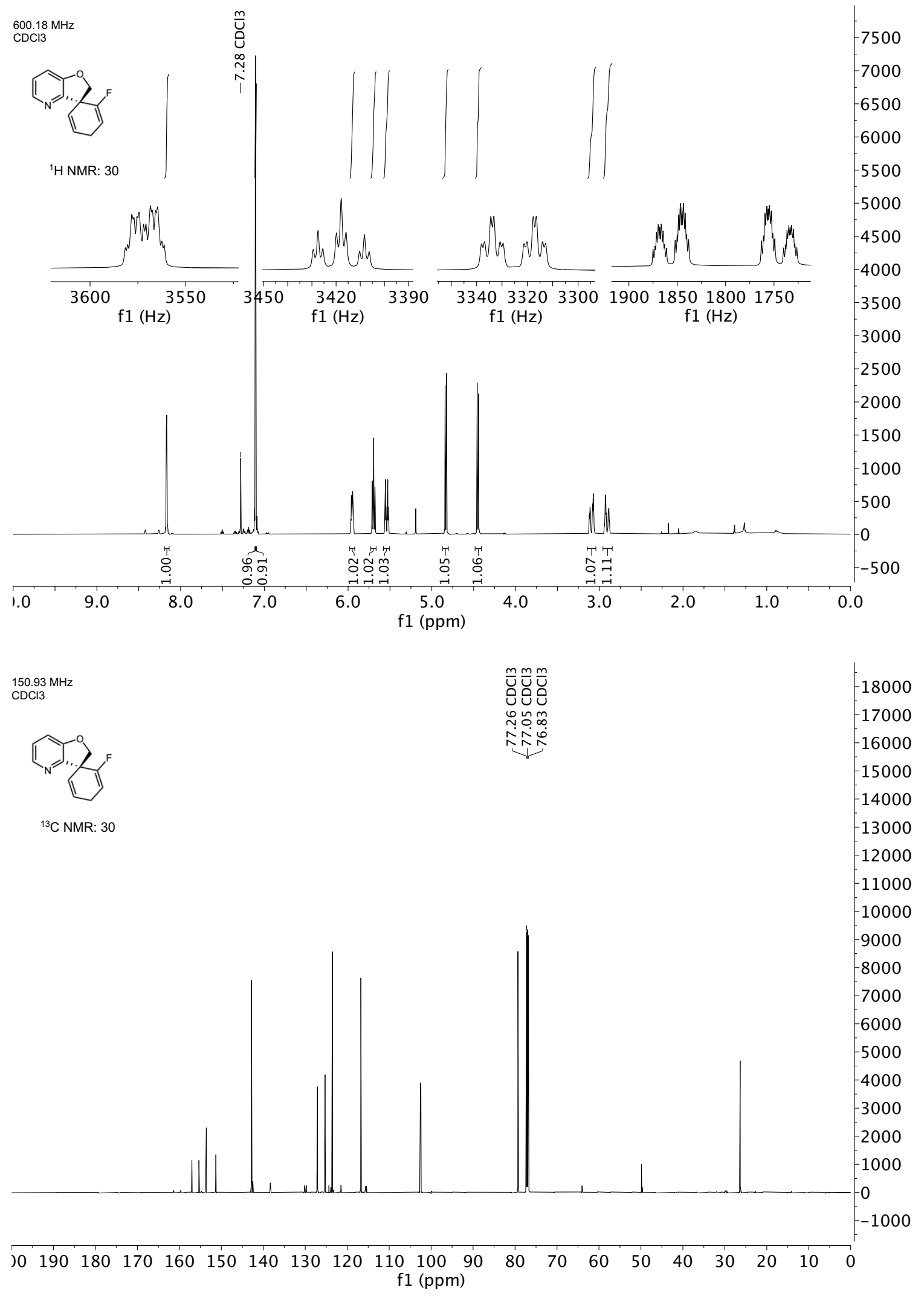




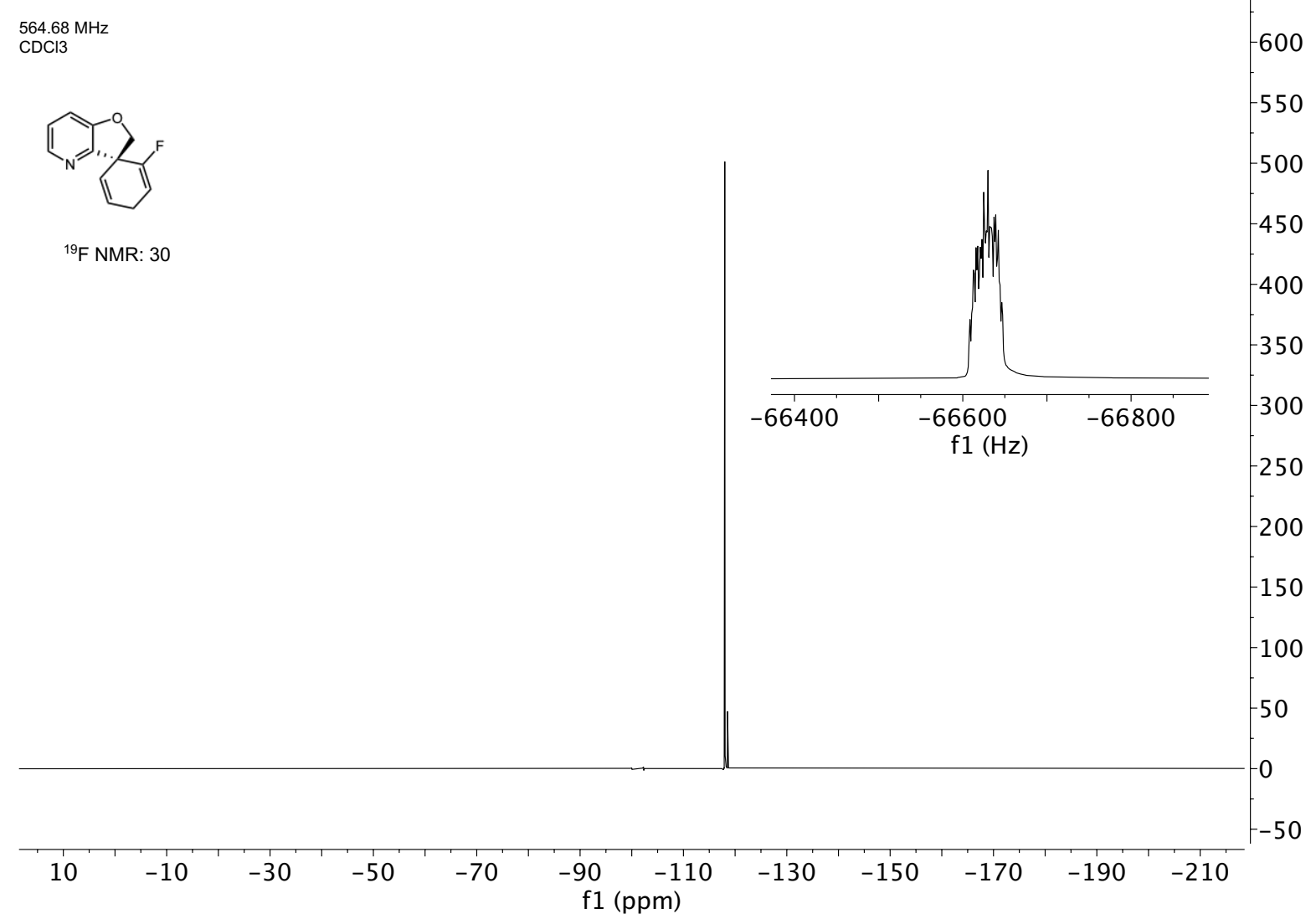




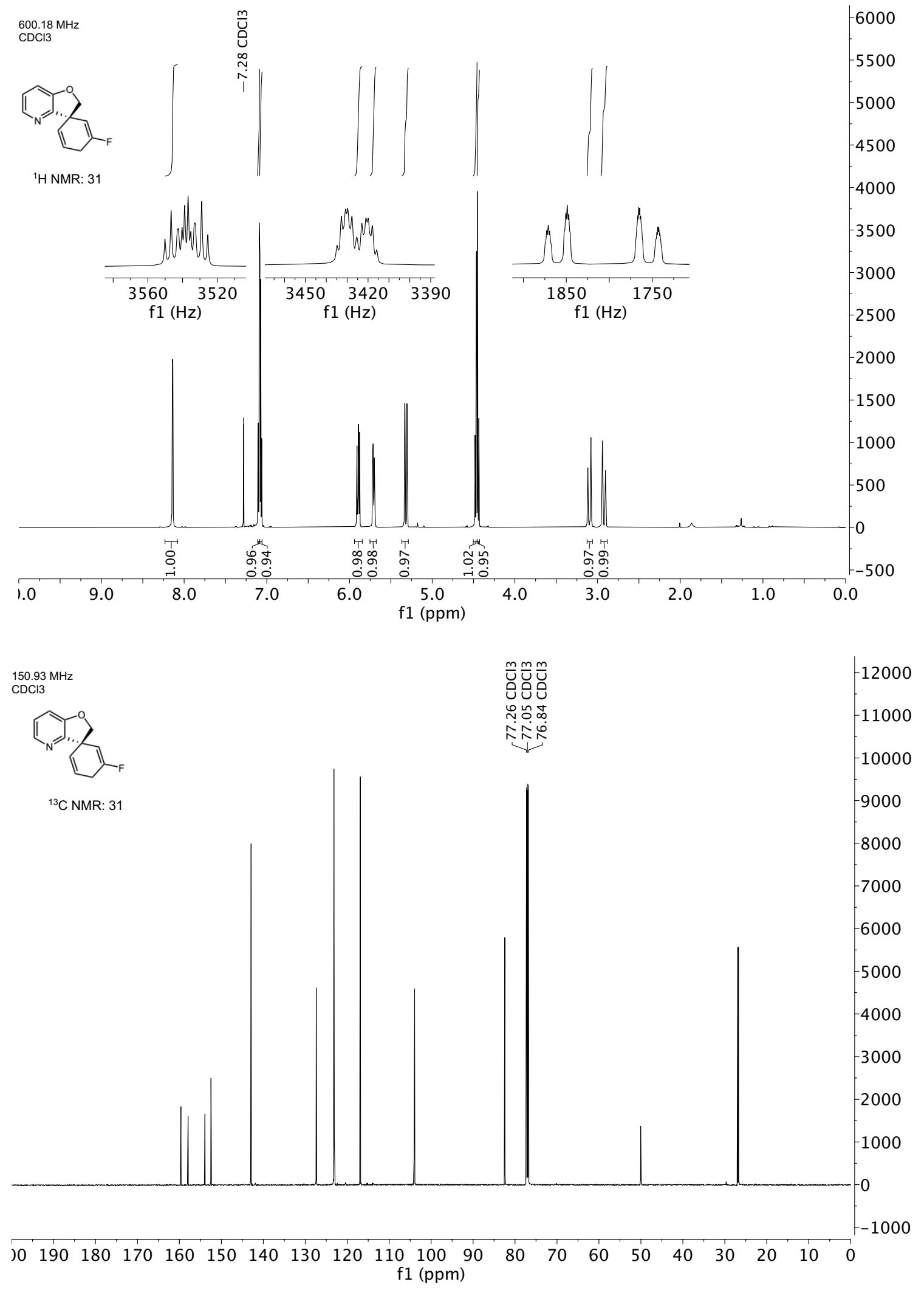




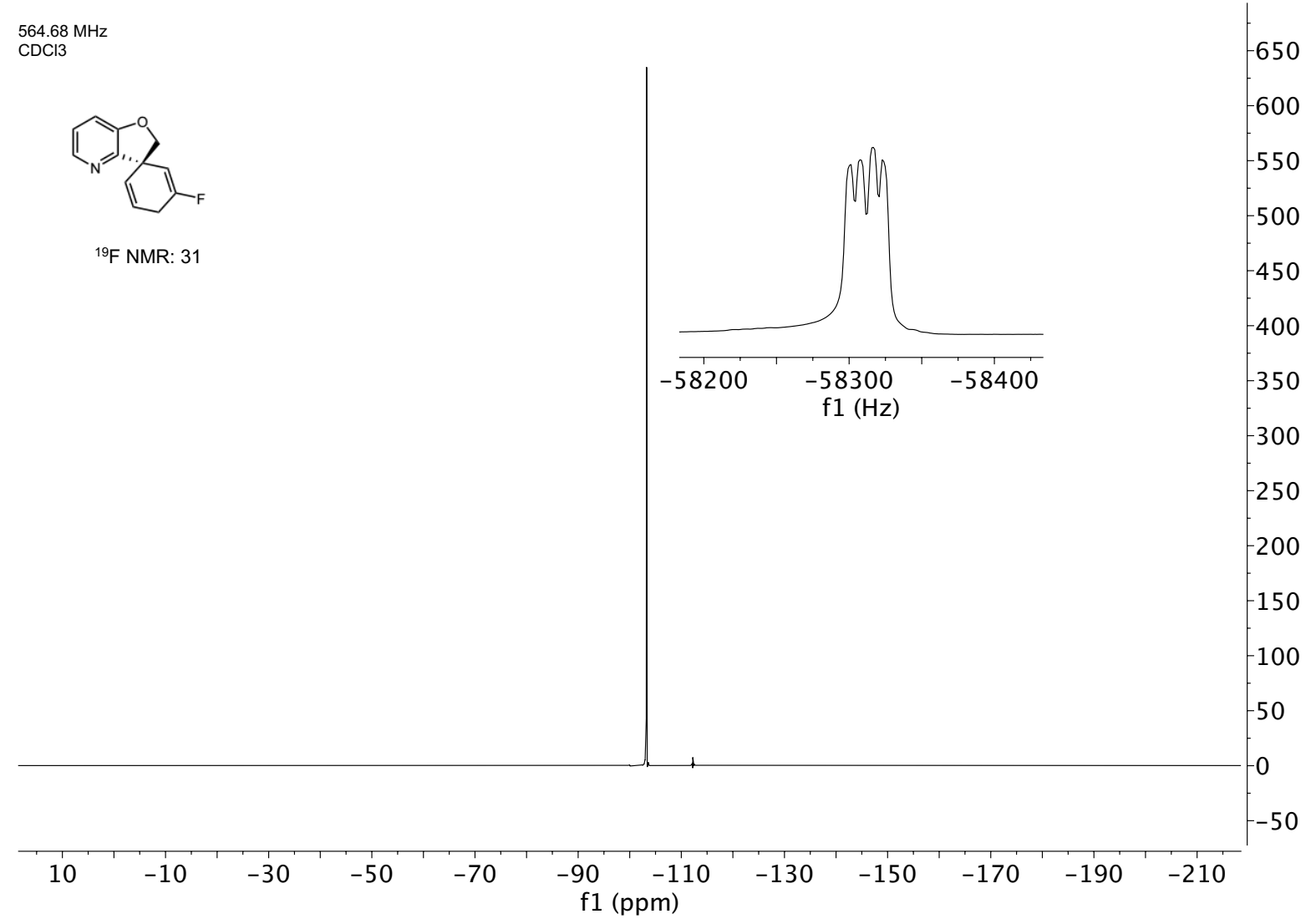




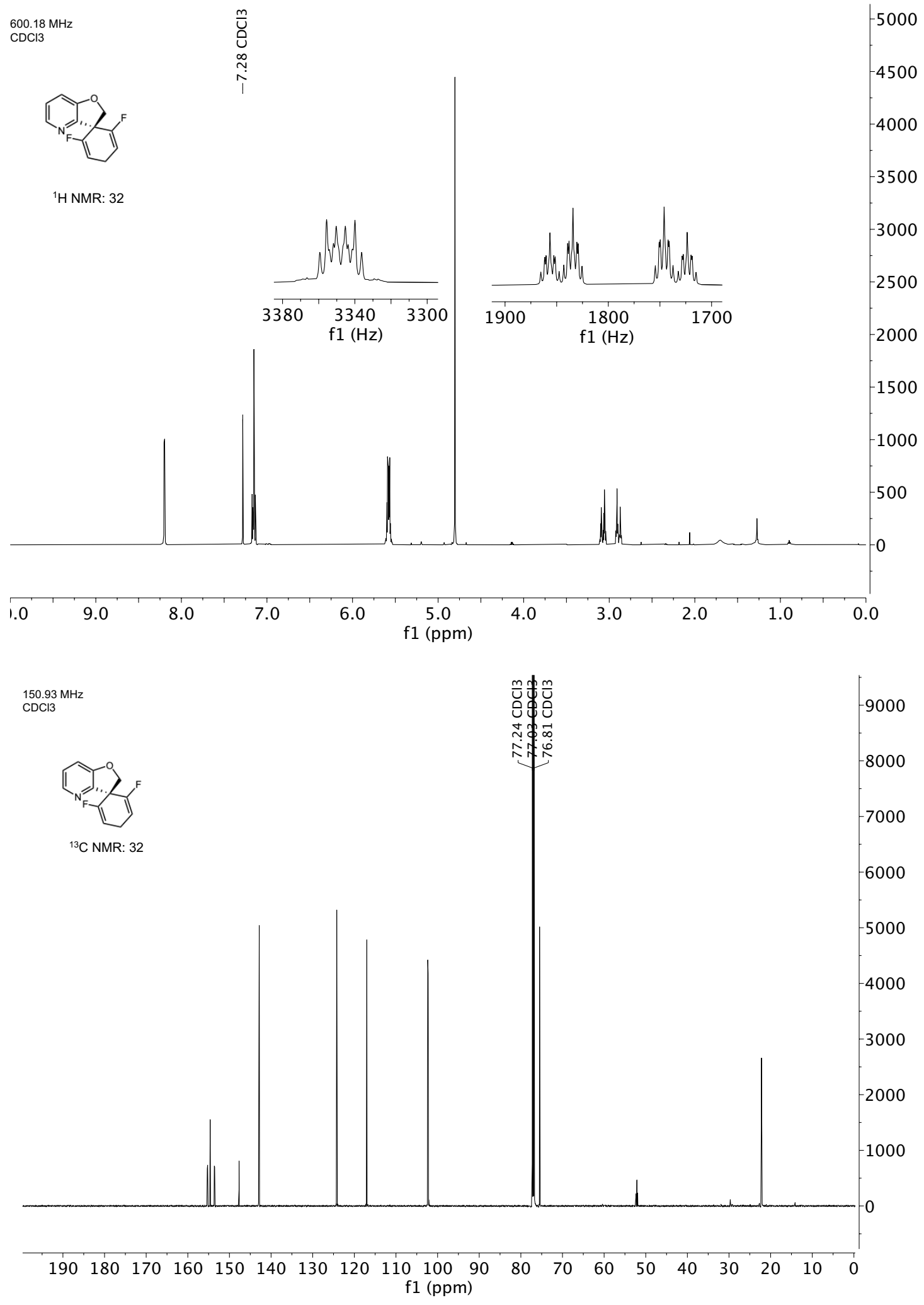




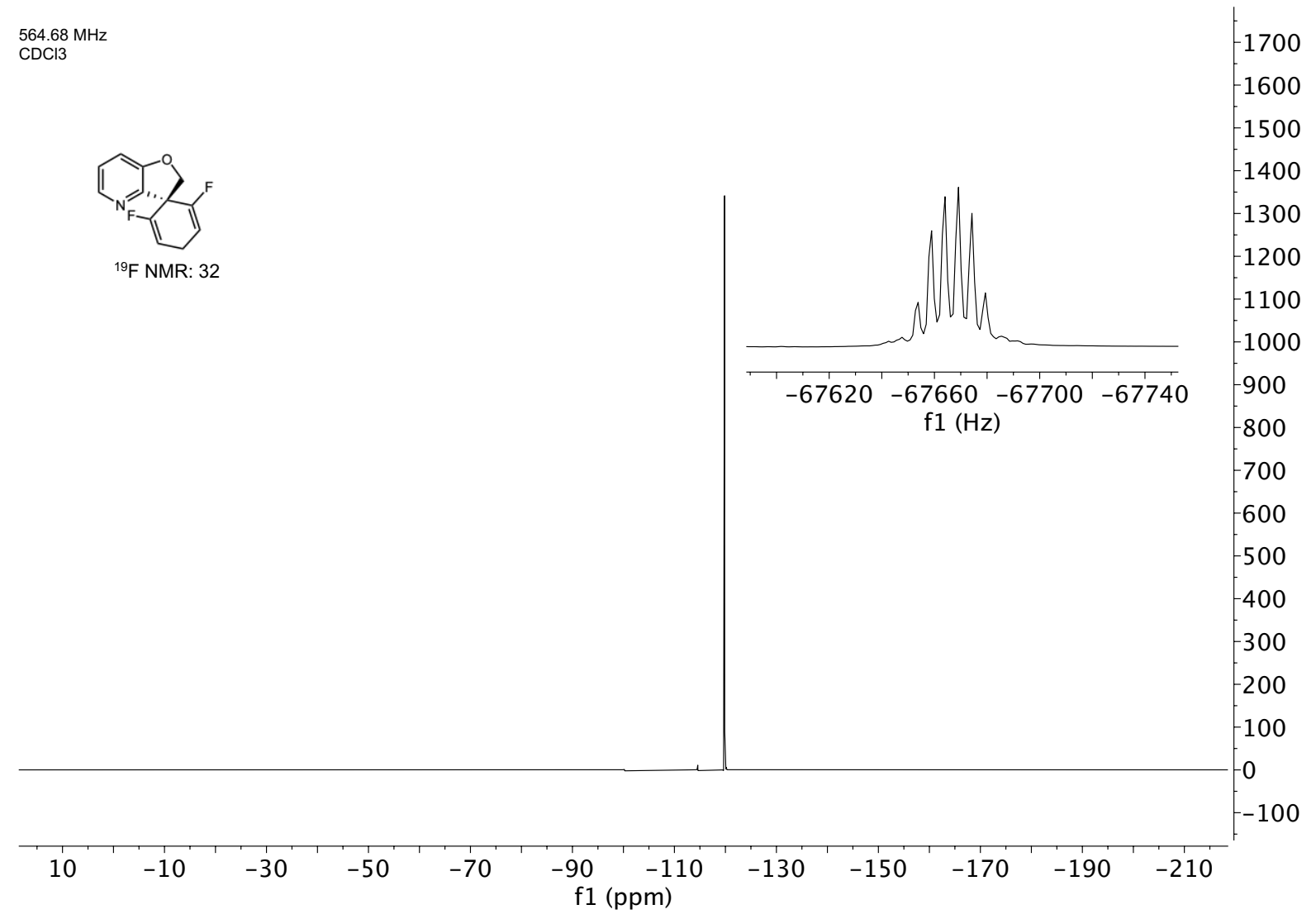




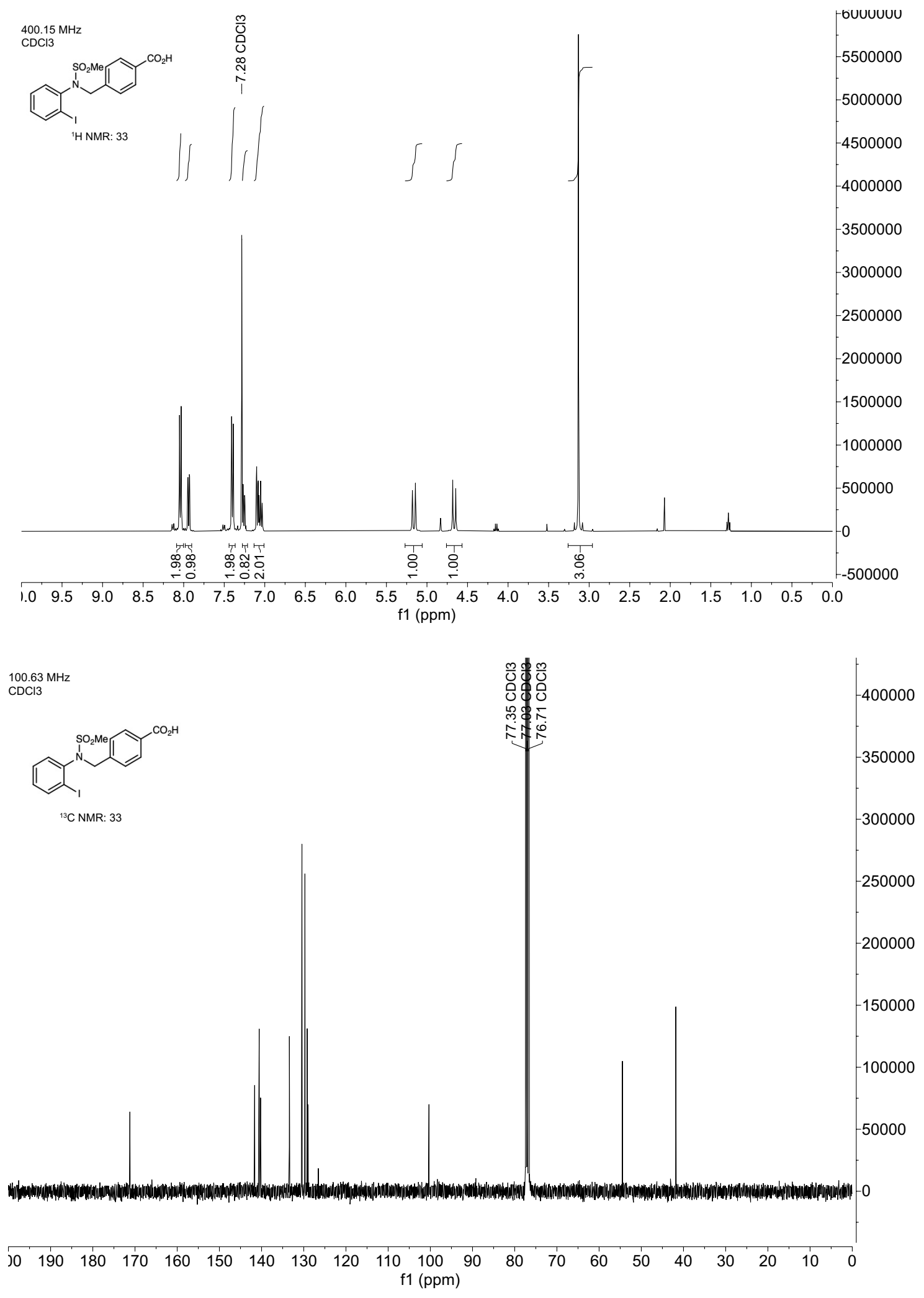




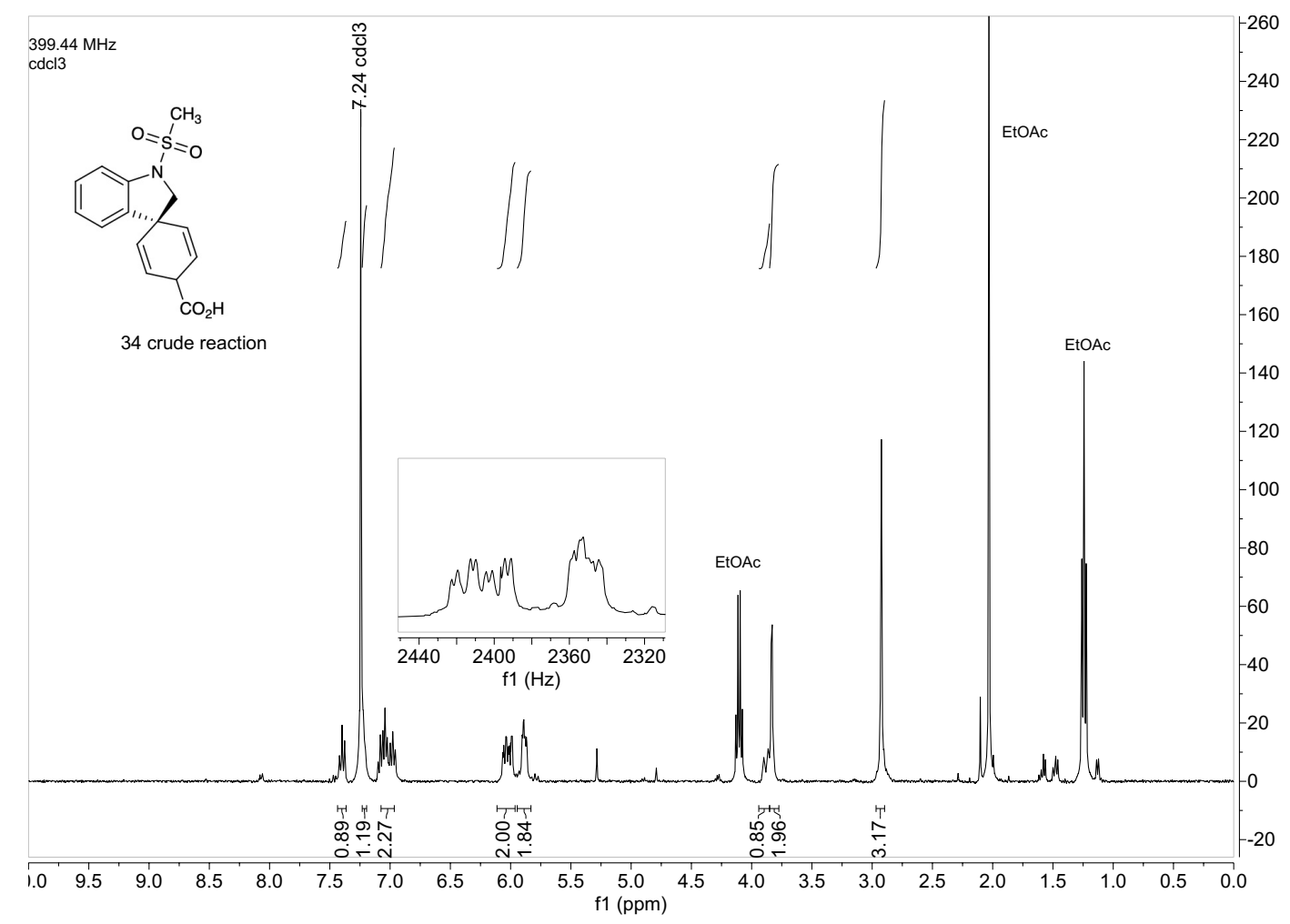




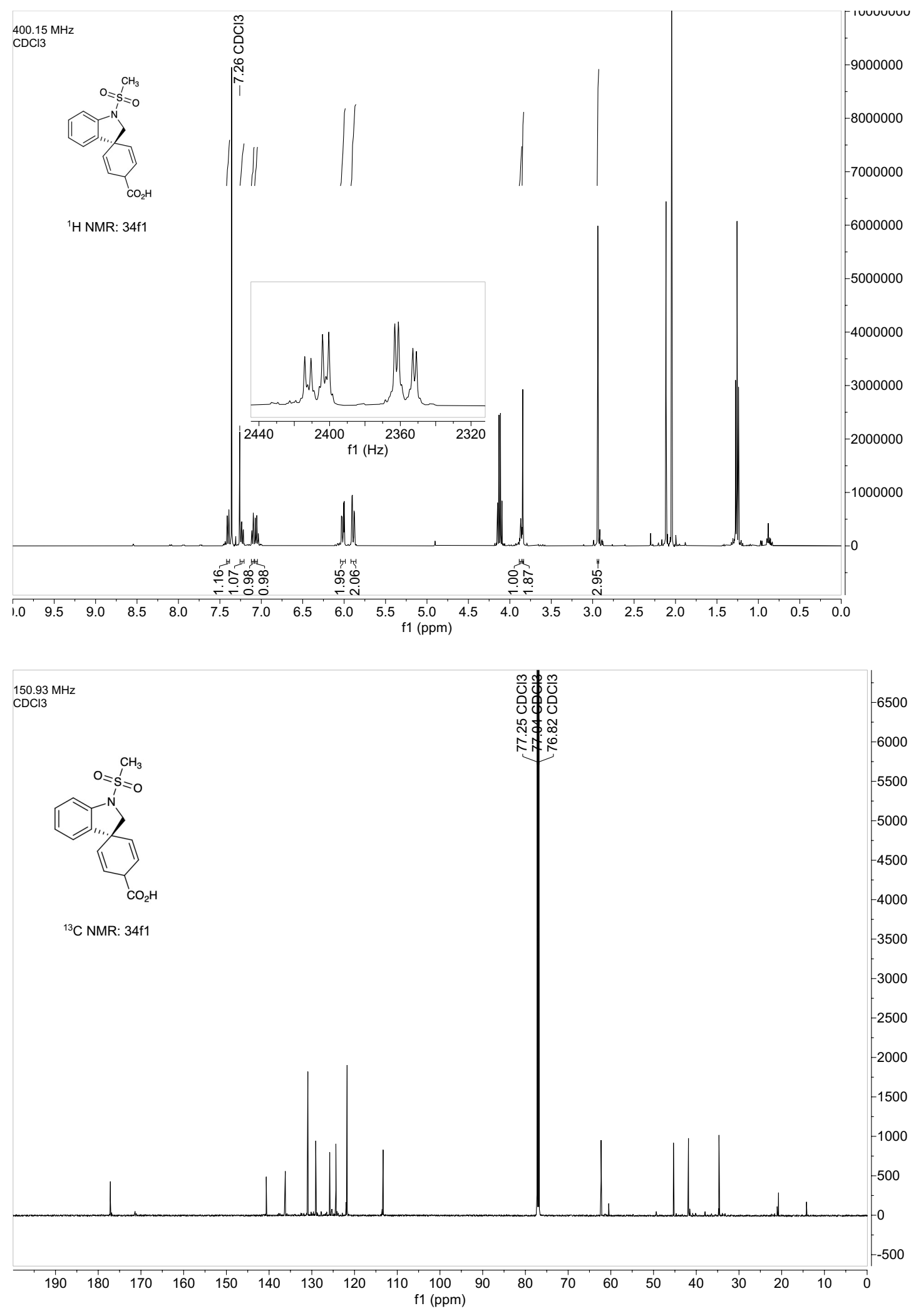




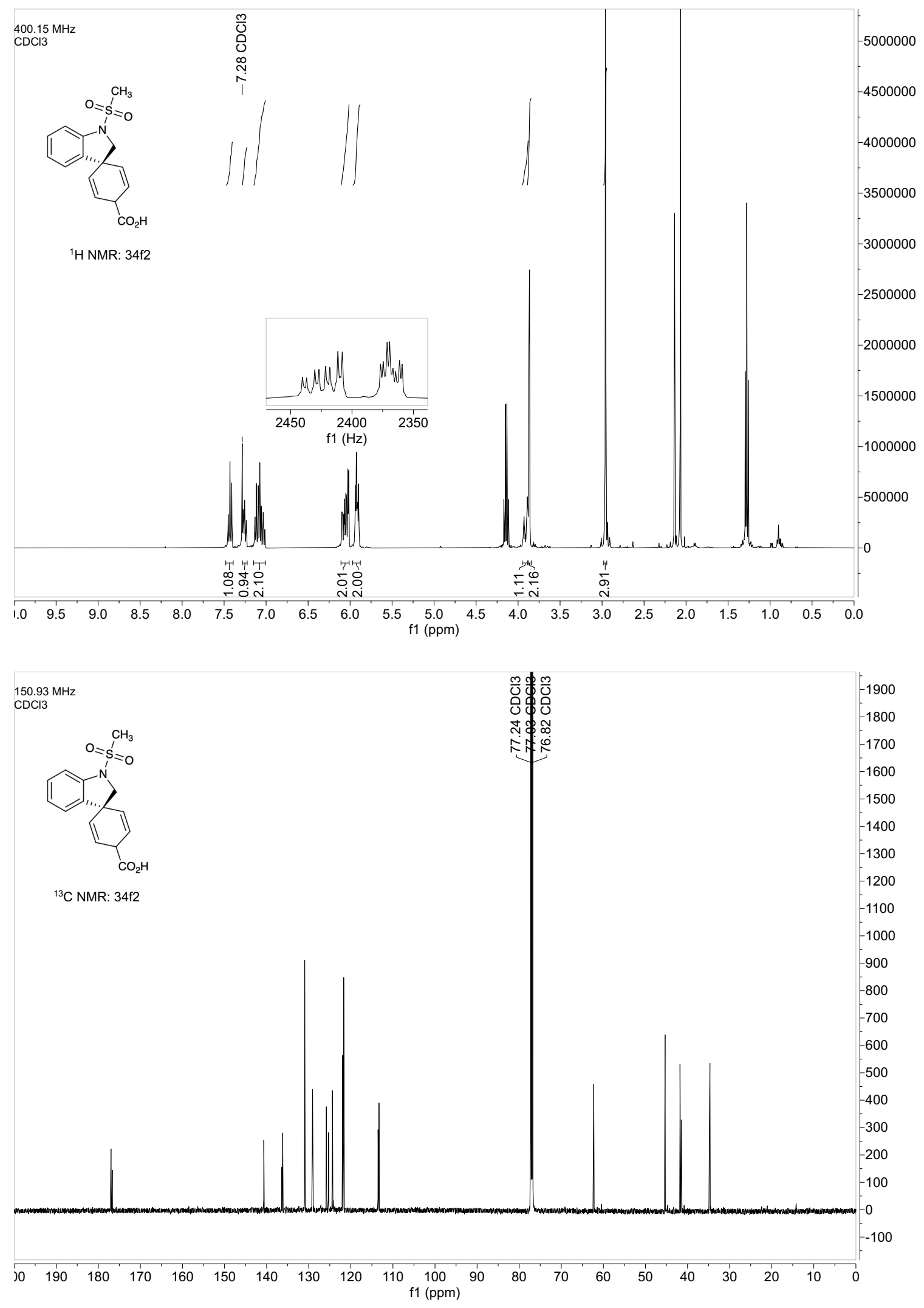




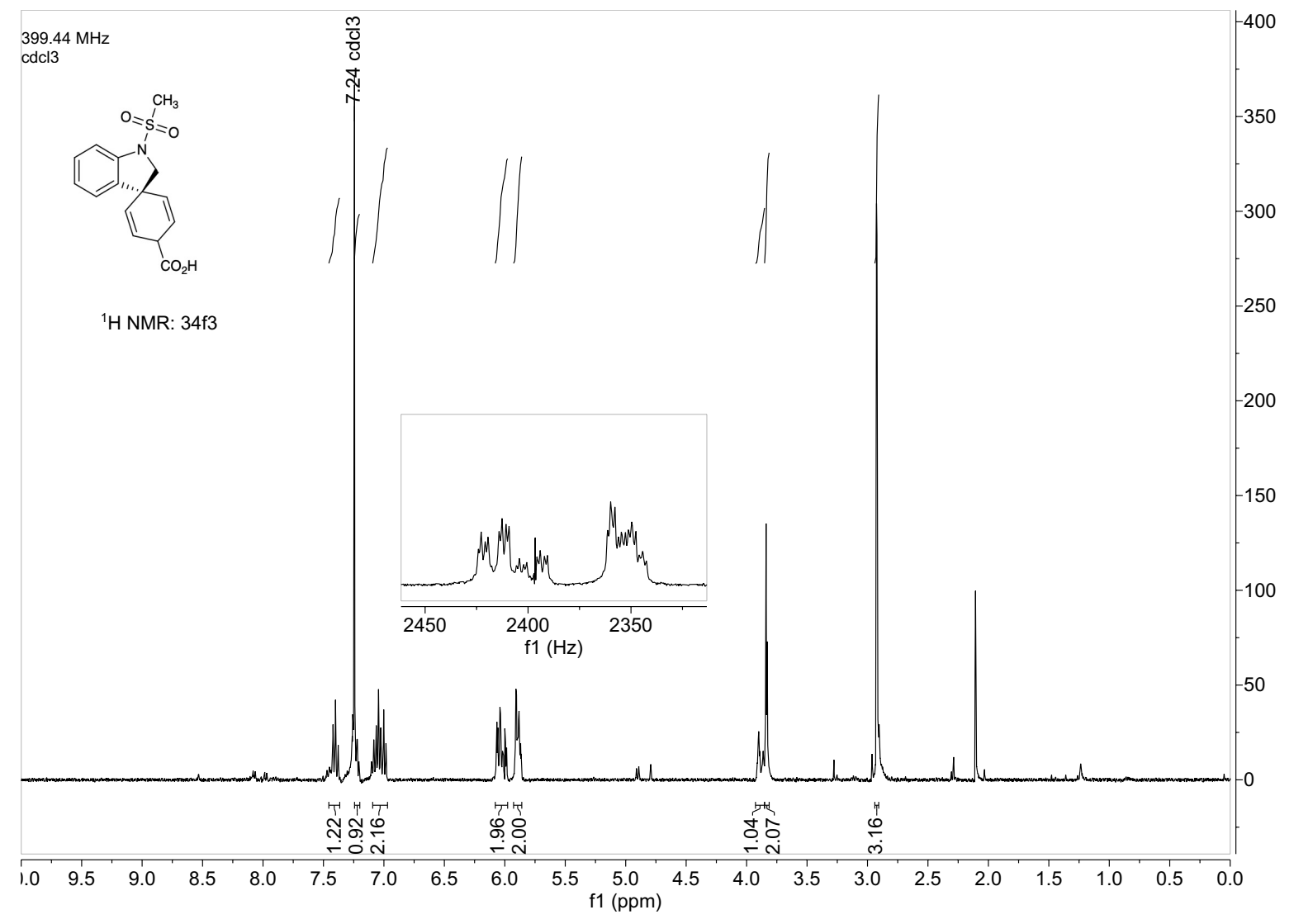




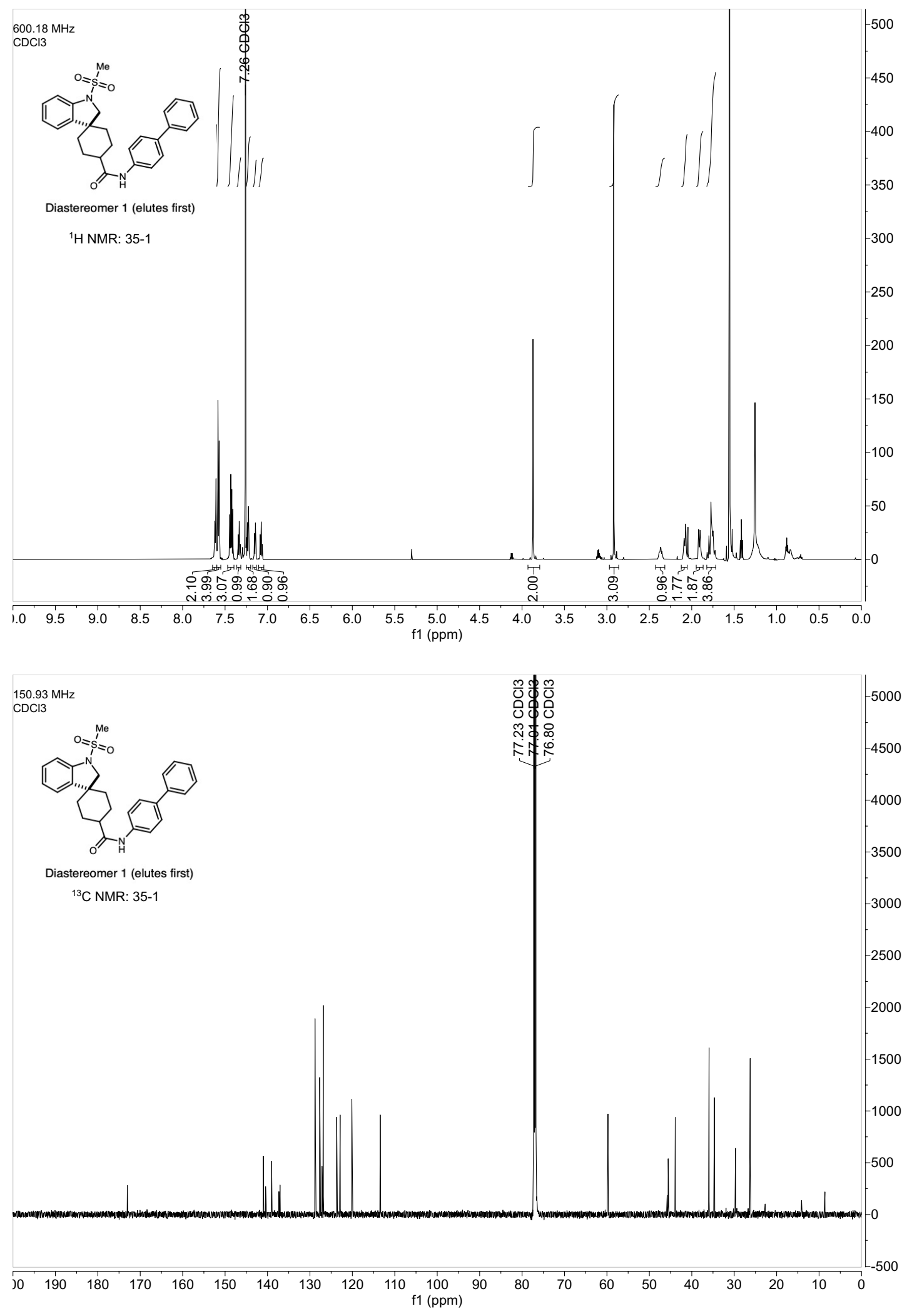



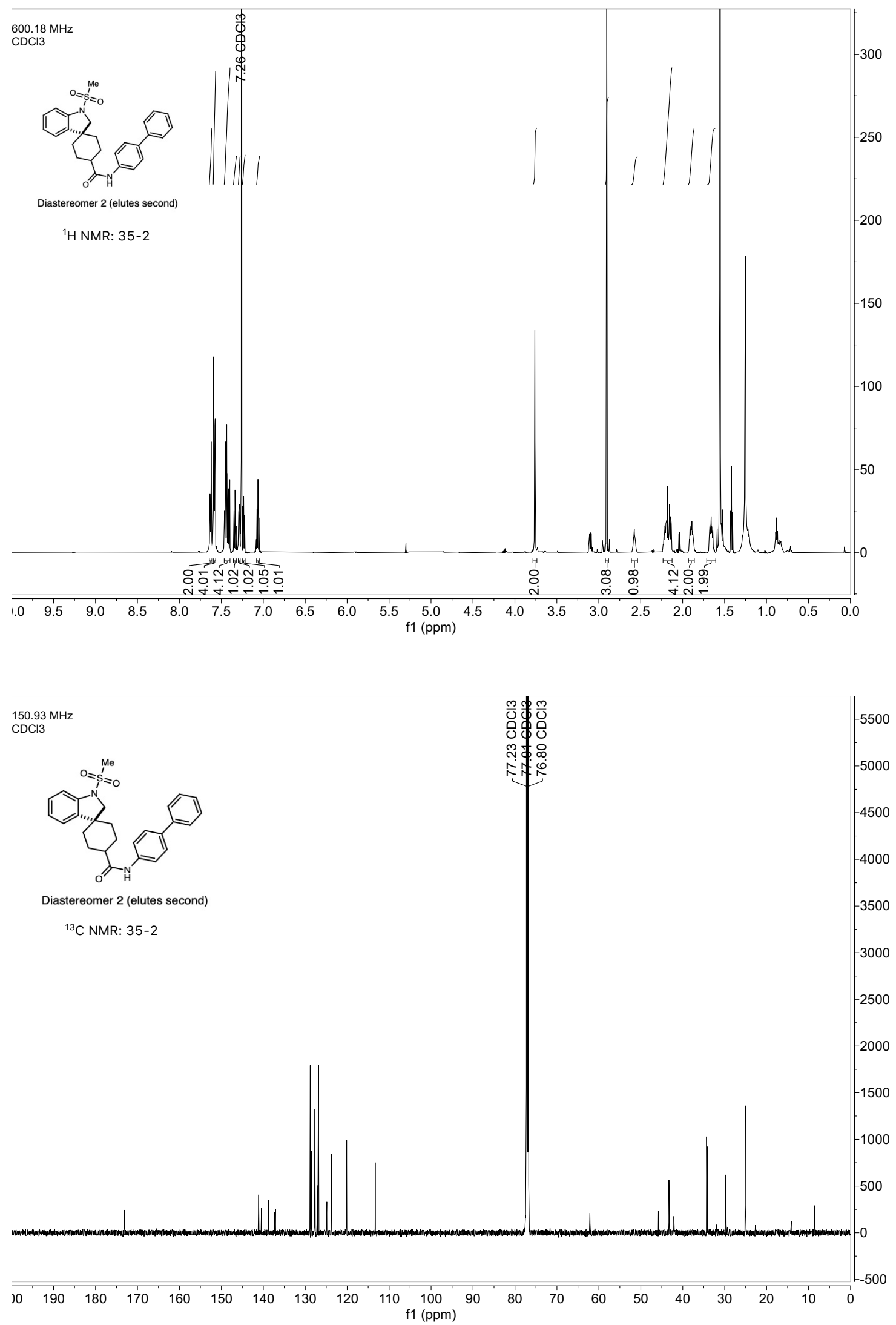